\begin{abstract}
UNIVERSIDADE DE SÃO PAULO
FACULDADE DE FILOSOFIA, LETRAS E CIÊNCIAS HUMANAS

Departamento de Letras Clássicas e Vernáculas

Programa de pós-graduação em Filologia e Língua Portuguesa
\end{abstract}

\title{
PROCESSOS INTERACIONAIS NA INTERNET: Análise da Conversação Digital
}

Artarxerxes Tiago Tácito Modesto

São Paulo, 2011 


\author{
UNIVERSIDADE DE SÃO PAULO \\ FACULDADE DE FILOSOFIA, LETRAS E CIÊNCIAS HUMANAS \\ Departamento de Letras Clássicas e Vernáculas \\ Programa de pós-graduação em Filologia e Língua Portuguesa
}

\title{
PROCESSOS INTERACIONAIS NA INTERNET: Análise da Conversação Digital
}

Artarxerxes Tiago Tácito Modesto

\begin{abstract}
Tese apresentada ao Programa de Pós-Graduação em Filologia e Língua Portuguesa, do Departamento de Letras Clássicas e Vernáculas da Faculdade de Filosofia, Letras e Ciências Humanas da Universidade de São Paulo, para obtenção do título de Doutor em Letras.
\end{abstract}

Orientador: Prof. Dr. Luiz Antonio da Silva

São Paulo, 2011 


\section{Dedicatória}

Dedico este trabalho à memória de meu pai Antonio Tácito Modesto, e às joias da minha vida, Jade e Yasmim Modesto. 


\section{Agradecimentos}

Ao Deus todo-poderoso, em primeiro lugar, por ter me colocado em um alto retiro, e me dado sabedoria e luz durante o processo de pesquisa e reflexão.

Ao professor Dr. Luiz Antonio da Silva, por ter sido paciente, humano, mas criterioso em sua orientação. Sem seu auxílio não seria possível concretizar este trabalho.

À professora Maria Zilda Aquino pelas observações, correções de rumo e paciência, e pelas orientações dadas na banca de qualificação.

Ao professor Paulo de Tarso Galembeck, pelas importantes observações no exame de qualificação.

A todos os membros da banca de exame de doutoramento.

A todos os professores do DLCV, pelo auxílio sempre presente.

Ao prof. Dr. Salvador Pons Bordería, da Universidade de Valência, Espanha, por ter colocado questionamentos importantes acerca deste trabalho.

Ao Prof. David Crystal pela inspiração e pelas respostas sempre presentes nos momentos de dúvida.

Ao secretário municipal de Educação de Cubatão, Fábio de Oliveira Inácio, por ter colaborado com a finalização da tese, permitindo a aplicação da lei 22 para minha licença remunerada da Prefeitura Municipal de Cubatão.

Ao professor Hélio Viegas, minha fonte de inspiração.

À minha família por ter dado incentivo e força, não deixando o desânimo tomar conta nem as forças se acabarem.

Em especial à minha amada esposa Heide Ketti C.J. Modesto, pelo apoio, paciência, dedicação e pelo amor verdadeiro e eterno.

À Faculdade do Litoral Sul Paulista (FALS) pelo apoio acadêmico durante o desenvolvimento da pesquisa

À Faculdade Don Domênico por ter apostado em minhas qualidades profissionais.

A todos os informantes que colaboraram para a obtenção dos dados vivos e dinâmicos do mundo digital. 


\section{Resumo}

O surgimento da Internet provocou uma revolução no que diz respeito a novas formas de interação entre as pessoas, oferecendo experiências de comunicação em tempo real, nos chamados ambientes virtuais. Diante desse cenário, novos gêneros textuais emergem, abrindo caminho para inúmeras possibilidades de análise sob os mais diversos enfoques. Neste trabalho, tomamos por objeto de estudo as conversações digitais, procurando verificar, num primeiro momento, em que medida estas se aproximam ou se distanciam das conversações face a face. Também procuramos, ainda, identificar, descrever e analisar algumas estratégias interacionais inerentes a esse novo gênero, além de observar a manifestação de fenômenos da (des)cortesia verbal entre os interlocutores que utilizam esta forma de comunicação. Buscamos embasamentos na perspectiva da Análise da Conversação e da Sociolinguística Interacional para definir o gênero digital e as estratégias conversacionais do "texto falado por escrito" na Internet. O corpus utilizado neste trabalho é formado por conversações digitais advindas do MSN, software de comunicação instantânea da Microsoft Corporation, escolhido devido à sua larga utilização entre pessoas que utilizam a internet para comunicação. Pretendemos, assim, contribuir para o estudo das conversações digitais no âmbito da língua portuguesa, oferecendo uma nova abordagem para o estudo das comunicações mediadas pelo computador.

Palavras - Chave: interação, conversação digital, comunicação mediada por computador, cortesia verbal. 


\begin{abstract}
The emergence of the Internet sparked a revolution regarding to new forms of interaction between people, offering experiences of real-time communication, in the so-called virtual environments. In this scenario, new text genres emerge, opening up new possibilities for analysis from various perspectives. In this work, our study object is the digital conversations, and we try to ascertain, at first, how these conversations are similar, approach or move away from face to face conversations. We seek also to identify, describe and analyze some interactional strategies inherent to this new genre, in addition to observing the manifestation of phenomena of verbal (dis) courtesy between the interlocutors who use this form of communication. Our basements are on the perspective of Conversation Analysis and Interactional Sociolinguistics, where we try to define the genre and digital strategies of conversational "spoken text written" on the Internet. The corpus used in this work is composed by digital conversations coming from the MSN instant messenger software from Microsoft Corporation, which was chosen because of its wide usage among people who access the Internet for communications. We intend, therefore, to contribute to the study of digital conversations in the Portuguese language scope, offering a new approach to the study of computer-mediated communications.
\end{abstract}

Key-Words: interaction, digital conversation, computer mediated communication, courtesy. 


\section{SUMÁRIO}

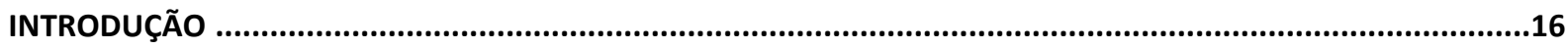

CAPÍTULO I ANÁLISE DA CONVERSAÇÃO E COMUNICAÇÃO MEDIADA POR COMPUTADOR .............................24

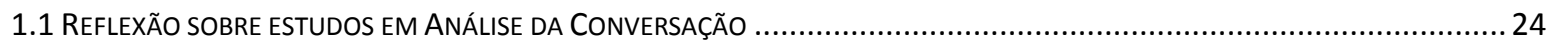

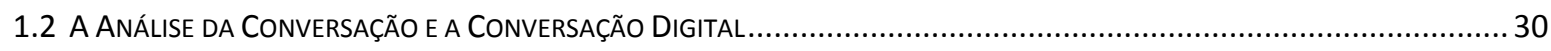

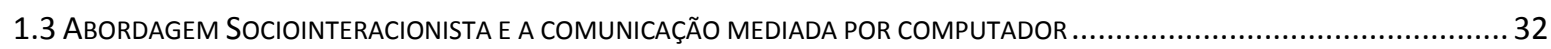

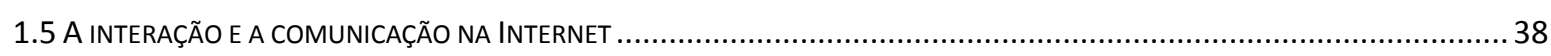

1.6 A CONVERSAÇÃO DIGITAL NUM CONTINUUM FALA/ESCRITA: A QUESTÃO DO GÊNERO.................................................... 41

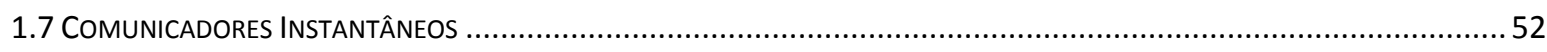

CAPÍTULO II ORGANIZAÇÃO E ESTRUTURA DA CONVERSAÇÃO DO TIPO FACE A FACE ....................................58

2.1 A ORGANIZAÇÃO CONVERSACIONAL FACE A FACE

2.2 CARACTERÍSTICAS DA CONVERSAÇÃO FACE A FACE

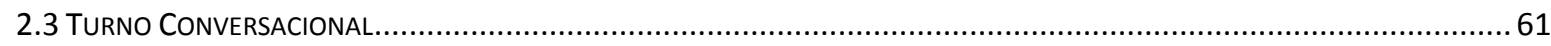

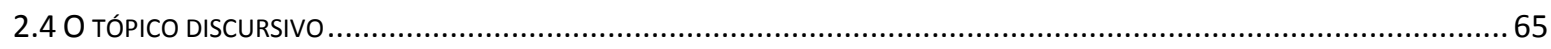

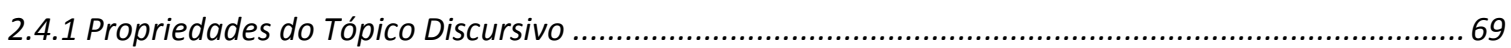

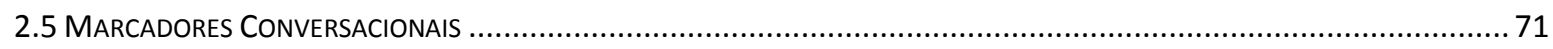

2.6 PROCEDIMENTOS DE FORMULAÇ̃̃o E REFORMULAÇÃo dO TEXTO FALADO. ……......................................................... 76

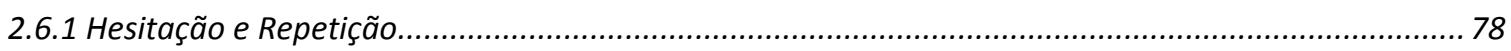

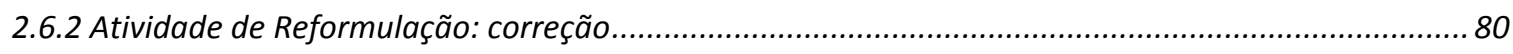

CAPÍTULO III A ORGANIZAÇÃO DA CONVERSAÇÃO DIGITAL NO MSN ..........................................................83

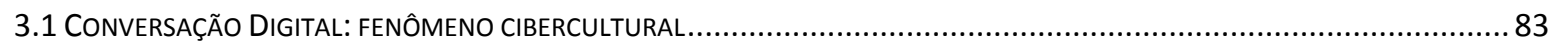

3.2 A QUESTÃO DO TURNO CONVERSACIONAL: UMA PROPOSTA DE RELEITURA PARA A ANÁLISE DIGITAL: O ATO ENUNCIATIVO

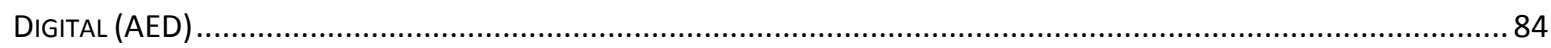

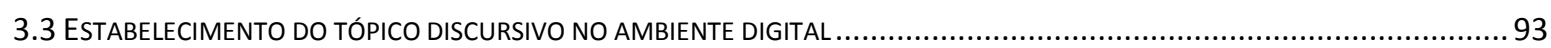

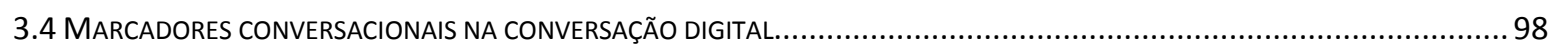

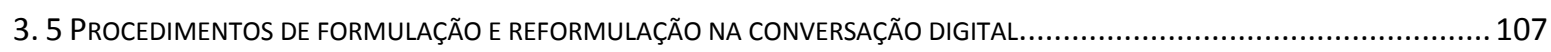

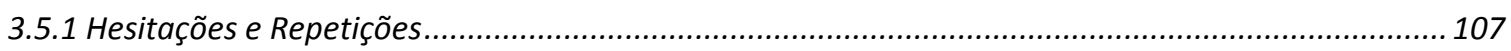

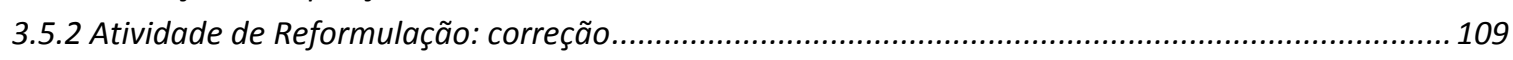

CAPÍTULO IV A CORTESIA VERBAL NA COMUNICAÇÃO HUMANA ..............................................................113

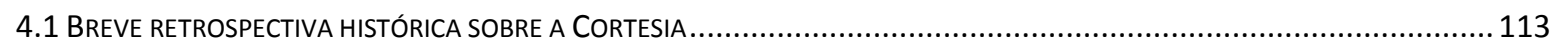

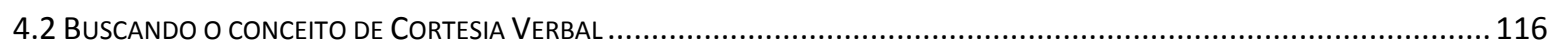

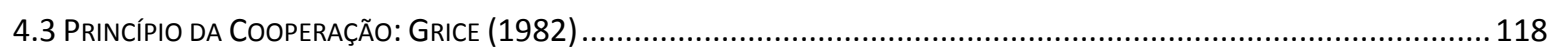

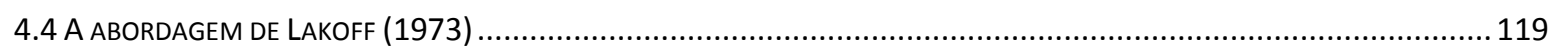

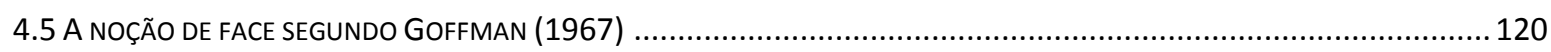

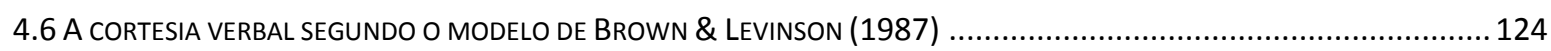

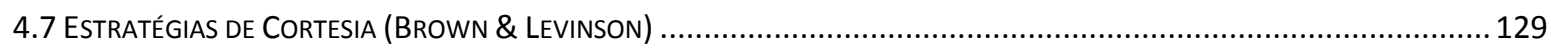

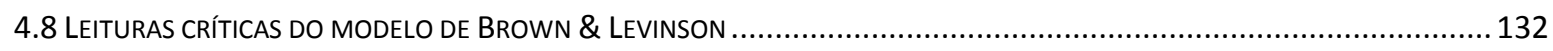

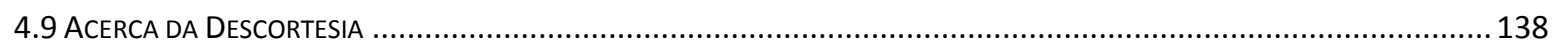

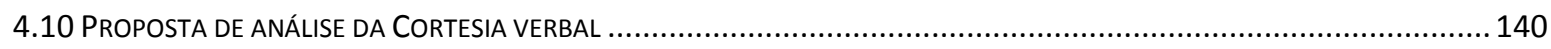

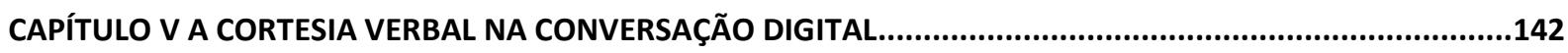

5.1 O PROCESSO DE EQUILÍBRIO INTERACIONAL: A BUSCA PELA HARMONIA NA CONVERSAÇÃO DIGITAL...............................142

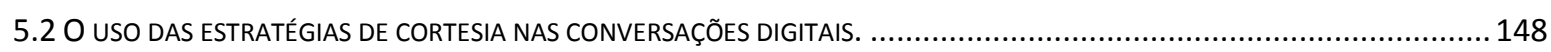

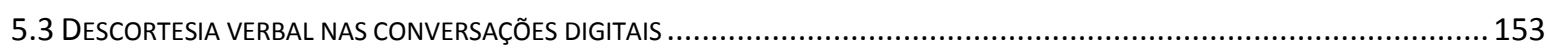

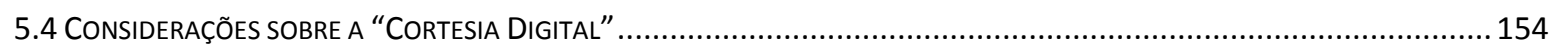




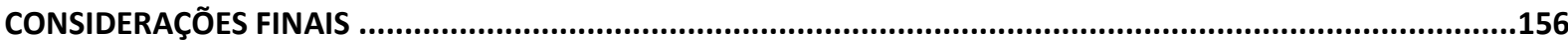

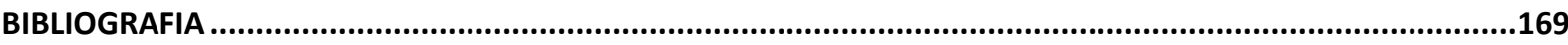

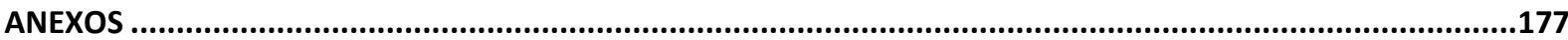




\section{LISTA DE TABELAS}

Tabela 1. Inquéritos digitais divididos por categorias sociolinguísticas...................................21

Tabela 2. Dicotomias estritas. (Adaptado de Marcuschi (2008, p.27)) ..................................44

Tabela 3. A perspectiva variacionista. Adaptado de Marcuschi(2008, p.31) ............................46

Tabela 4. Perspectiva sociointeracionista. Adaptado de MARCUSCHI(2008, p.33) ...................46

Tabela 5. Distribuição do gênero Conversação Digital de acordo com o meio de produção e a

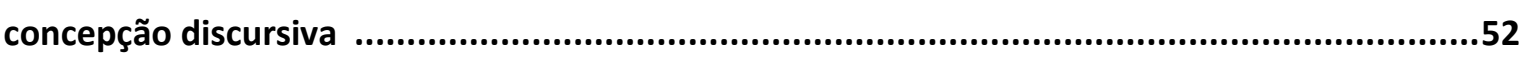

Tabela 6. Incompatibilidades entre o sistema de conversação prototípico e a conversação digital. .88

Tabela 7. Diferença entre o turno e o AED .............................................................................91

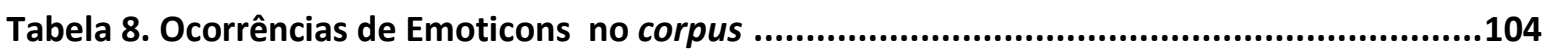

Tabela 9. Tipos de Marcadores de Atenuação (ROSA:1992, p. 61) ...........................................136

Tabela 10. Estratégias de (Des)cortesia Verbal Digital .........................................................154

Tabela 11. Exemplos de Emoticons no corpus. .....................................................................162

Tabela 12. Estratégias de (Des)cortesia Verbal Digital .......................................................167 


\section{LISTA DE FIGURAS}

Figura 1. Representação do continuum dos gêneros textuais na fala e na escrita (MARCUSCHI:2008) .50

Figura 2. Representação da oralidade e escrita pelo meio de produção e concepção discursiva. (MARCUSCHI:2008). .51

Figura 3. Demonstração das funções do Microsoft Messenger ............................................53

Figura 4. Relação homem - homem com mediação de computadores ….................................54

Figura 5. Organização Tópica (JUBRAN et ali:1992) ..............................................................68

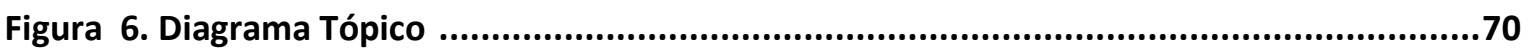

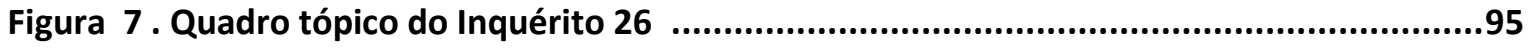

Figura 8. Quadro Tópico (Tópicos Pareados) ............................................................................98

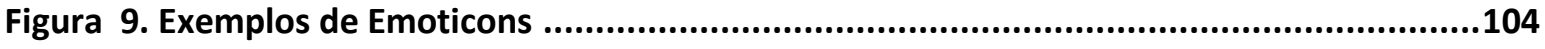

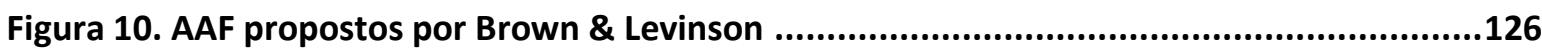

Figura 11. Possíveis estratégias para realizar um FTA (BROWN\&LEVINSON:1987, p. 69) .........129

Figura 12 . Modelo de Ato de Reparação (adaptado de Snyder et al. 1983) .............................135

Figura 13. Representação da Cortesia e Descortesia Verbal .................................................140

Figura 14 . Quadro Tópico da Conversação Digital ..............................................................160 


\section{INTRODUÇÃO}

Com a invenção dos computadores e seu aprimoramento a partir da década de 40 , temos presenciado uma revolução como nunca se viu antes. Tudo começou quando o americano John Von Newmann e sua equipe da Universidade de Pensilvânia arquitetaram a estrutura básica do que seria o protótipo dos computadores atuais: uma unidade de processamento Central (CPU ou Central Processing Unit) e uma unidade de armazenamento (discos).

No início, complexas linguagens de programação eram executadas para que o homem pudesse se comunicar com a máquina, e direcioná-la a executar determinados comandos. Com o passar dos anos, as linguagens dos programas foram se tornando mais "amigáveis" até chegarmos aos ambientes gráficos multitarefa que conhecemos hoje, como - Windows, utilizado amplamente pela maioria dos usuários de computador. Softwares como o Windows admitem que diversos programas fiquem à disposição do usuário ao mesmo tempo, permitindo uma ampla flexibilidade de uso.

A partir da década de 80 , os computadores começaram a se popularizar, e hoje são usados em casas e escritórios de milhões de pessoas no mundo inteiro. Desde então, temos presenciado uma constante "miniaturização" dessas máquinas, tornando-as acessíveis física e economicamente para pessoas e instituições.

Com o advento do computador, surgiu também a comunicação em rede, ou Internet. A Internet se desenvolveu nos tempos da Guerra Fria, com o nome de ArphaNet. Tinha o objetivo de manter a comunicação das bases militares dos Estados Unidos, mesmo que o Pentágono fosse destruído. Após a ameaça da Guerra Fria, a rede ArphaNet foi aberta para cientistas e universidades, que sucessivamente passaram-na para outras instituições e países diversos, sendo nomeada definitivamente como Internet.

A internet se resume basicamente a um conjunto de redes interligadas, de abrangência mundial, isto é, a um conjunto de tecnologias que visam ao acesso, distribuição e disseminação de informação em rede. A utilização da internet, cada vez mais intensa, em larga escala, possibilitou a produção de uma linguagem própria entre os seus usuários, 
constituída por termos específicos que tem como finalidade facilitar a comunicação entre os interactantes.

Nos dias atuais, a Internet constitui certamente o maior sistema de comunicação que o homem já desenvolveu. Com o surgimento da World Wide Web (sistema www, para acessar páginas remotas), em meados de 1980, a Internet se tornou ainda mais poderosa. Formou-se uma rede de computadores interligados que fornecem informações mutuamente em forma de hipertexto, que são textos nos quais se encontram ligações (links) para outras páginas. Com essa ferramenta, incorporaram-se imagens e sons à rede.

A Internet se constituiu, então, de um conjunto de redes de computadores interligadas, de forma que os usuários compartilham serviços de informação e comunicação de forma global.

Juntamente com toda essa evolução, desde os primeiros momentos, houve o surgimento de meios de comunicação digital. Inicialmente, veio o e-mail, em meados de 1960 e, desde então, os meios de comunicação eletrônicos foram se aprimorando, até o surgimento de diversos comunicadores instantâneos. Os mais conhecidos atualmente são o ICQ e o MSN. São aplicações que permitem o envio e recebimento de mensagens de texto em tempo real. Por meio desses programas, o usuário é informado quando algum de seus amigos, cadastrado em sua lista de contatos, é conectado à rede.

A partir daí, eles podem manter conversações por meio de mensagens de texto - ou até som e imagem. Normalmente, esses programas incorporam diversos outros recursos, como envio de figuras ou imagens animadas, conversação em áudio - utilizando as caixas de som e microfone do sistema, além de vídeo-conferência. Inicialmente, eles possibilitavam a conversação entre dois interlocutores apenas, mas hoje suporta diversos interlocutores ao mesmo tempo. Outra forma de manter essas conversações digitais é por meio dos chamados "bate-papos" ou "chats", oferecidos por sites em diversos pontos da rede. Entre os mais conhecidos estão o UOL, YAHOO e BOL.

O Bate-papo também permite uma conversa em tempo real entre diversas pessoas, em ambientes remotos, por meio de mensagens escritas e/ou sonoras. É dividido em salas temáticas, e permite que usuários com interesses comuns possam trocar ideias e 
informações acerca do tema escolhido. Também tem sido utilizado para ensino à distância, entretenimento, transmissão de eventos, suporte para clientes em empresas, entre outros.

O desenvolvimento dessas novas tecnologias e a consolidação dos meios eletrônicos digitais como instrumentos de comunicação trouxeram à vida cotidiana do homem inúmeras ferramentas de interação inovadoras por meio da Internet. Segundo Machado (2002, p.119), “...a interação não é exclusividade da linguagem natural, mas diz respeito também às linguagens artificiais, que tornam-se, assim, produtoras de gêneros".

Os gêneros digitais se definem no e pelo contexto digital em que estão inseridos, ou seja, pelas formas comunicativas processadas digitalmente ou pela via on-line, pela conexão e estrutura de computadores. Caracteriza-se, dessa forma, por arquiteturas computacionais modelizadas por linguagens artificiais, criadas pela engenharia digital, para combinação e reprocessamento de sistemas de escrita e de gêneros literários, discursivos, de gêneros informativos da mídia impressa, da linguagem visual, dos gêneros audiovisuais, entre outros. (MACHADO:2002, p.121)

O surgimento dos gêneros digitais trouxe consigo uma nova atitude também diante da linguagem e da conversação como um todo: esta seria realizada em tempo real, mas mediada pelo computador e, essencialmente, por escrito.

Seria necessário, então, escrever a mensagem a ser enviada. Isso exigiria rapidez e dinamicidade por parte do "falante-digitador", pois o interlocutor estava em um outro ponto da rede, esperando o retorno de seu contato.

Na verdade, segundo Hilgert (2000, p.17), os interlocutores, que estão em contato por um canal eletrônico, sentem-se falando, mas, pelas especificidades do meio que os põe em contato, são obrigados a escrever suas mensagens. Interagem, assim, construindo um texto "falado por escrito".

Essa premissa, de um texto falado por escrito em que os interlocutores utilizam estratégias conversacionais próprias da língua falada, numa integração clara entre os dois tipos de linguagens, orienta todo o trabalho aqui apresentado. Com a entrada definitiva da Internet conectando pessoas no mundo inteiro, as condições de produção e divulgação de conhecimento, bem como as formas de comunicação conheceram novas dimensões. 
Segundo Crystal (1996), o surgimento de uma nova categoria de disciplina acadêmica não acontece com frequência, mas a chegada da Internet provocou tamanho impacto sobre língua que o momento é propício para a identificação e exploração do escopo do que se poderia chamar de 'Linguística da Internet', que aqui consideramos como a 'Linguística Digital'.

Ainda segundo o linguista britânico, esta nova 'disciplina' seria então delimitada por uma análise sincrônica da língua / linguagem em todas as áreas da atividade digital, incluindo o e-mail, os vários tipos de salas de bate-papo e interações em jogos, comunicadores instantâneos e páginas da web.

Do ponto de vista da Sociolinguística, de uma forma geral, a Internet trouxe à linguagem novas formas de variações estilísticas, e potencializou o alcance da expressividade nas conversações digitais simétricas. Essas formas de expressão podem manifestar-se nos mais diversos planos, desde a repetição de caracteres para enfatizar o tópico discursivo, até o uso dos emoticons e extensão dos sinais de pontuação.

Para a Análise da Conversação e a Sociolinguística Interacional, a Internet é um desafio a ser considerado. Ela permitiu que a linguagem se desenvolvesse em um novo meio de comunicação, diferente da conversação face a face tradicional e mesmo da forma escrita convencional. Segundo Crystal, há muitas diferenças entre a conversação mediada por computador e a conversação face a face. Na Conversação Mediada pelo Computador, a ausência da obrigatoriedade de um feedback simultâneo (essencial para a manutenção da conversação) provoca, muitas vezes, perda do tópico discursivo e, por vezes, a desistência de um dos interlocutores. Outro fator, segundo o autor, é a ausência da configuração entonacional da voz, que fica a cargo dos signos chamados de emoticons.

Segundo Crystal (1996), a natureza da conversação, do diálogo na Internet é muito diferente de outros grupos. Nem todas as noções tradicionais de análises da conversação funcionam bem ao analisar a linguagem da Internet. Como exemplo, ele cita que, ao entrar em uma sala qualquer de bate-papo, nunca se sabe quantas pessoas estão engajadas em uma conversa e tampouco quem são essas pessoas. Coloca-se um comentário para alguém e

\footnotetext{
1 "The emergence of a new branch of an academic discipline does not take place very often, but the arrival of the Internet has had such an impact on language that I believe the time is right to recognise and explore the scope of a putative 'Internet Linguistics'."
} 
espera-se que essa pessoa responda, mas talvez ela nem esteja mais conectada. E, ainda assim, as salas de bate-papo estão sempre lotadas, com conversas longas engajadas.

Devemos entender com ressalvas todas essas afirmações de Crystal, pois nos comunicadores instantâneos, como o MSN, as pessoas precisam trocar e-mails para efetivar um contato, cadastrar o interlocutor em sua lista de amigos, e, não raras vezes, se conhecem pessoalmente. Só esses fatos já serviriam para levantarmos a suposição de que, ao estabelecer o contato por esta via, os interlocutores se engajam na conversação, assim como ocorreria numa situação face a face.

Crystal(2002), ao tratar dos grupos de comunicação sincrônicos, como as salas de bate papo e os comunicadores instantâneos, expõe que a conversação eletrônica surge a partir dos princípios que regem a conversação face a face. O autor questiona alguns conceitos, como a alternância de turno, que, segundo o linguista, nem sempre se aplica ao contexto digital, uma vez que o interlocutor A não espera, necessariamente, que o interlocutor $B$ termine de escrever sua mensagem para enviar uma resposta. Em princípio, acredita que as partes envolvidas no processo comunicativo "teclam" simultaneamente, e não raras vezes, acontecem mal-entendidos. Crystal afirma ser extremamente difícil seguir a sequência de acontecimentos que tomam lugar na interação.

São questões conversacionais complexas e intrigantes como estas levantadas acima, do ponto de vista da inovação comunicativa trazida pela Internet, que neste trabalho procuramos estudar, analisar, descrever e explicar. Novas formas de conversação estão surgindo, e cabe aos linguistas tratar cientificamente o fenômeno, de maneira que haja não somente uma descrição deste, mas ferramentas de análise e explicações epistemologicamente coerentes sobre o processo interativo.

Nosso objetivo neste trabalho é descrever e analisar as principais características das conversações digitais, ou seja, aqueles diálogos ocorridos em tempo real, entre duas pessoas, mediados pelo computador. Selecionamos para este objetivo um software específico: o MSN, da Microsoft Corporation, devido à sua larga utilização entre as pessoas que utilizam a internet para comunicação.

Pretendemos levantar os principais aspectos da estrutura da conversação digital, verificando como se configuram os elementos essenciais que permitem a interação verbal: 
tópico discursivo, turno, marcadores, correções, entre outros. Também investigaremos aspectos da cortesia verbal no ambiente virtual, buscando semelhanças e diferenças entre os usos das estratégias nos dois planos (real/digital).

O corpus deste trabalho consiste em um acervo de 30 conversações digitais, coletadas entre 2007 e 2011, a partir dos históricos de conversas dos programas MSN, mediante autorização prévia dos usuários, por meio da cópia de seu histórico de conversas. Apresentamos, a seguir, a tabela apresentando os inquéritos divididos por faixa etária e sexo.

\begin{tabular}{|c|c|c|c|}
\hline Sexo & \multicolumn{3}{|c|}{ Faixa Etária } \\
\hline & $\mathbf{1 5 - 2 0}$ anos & $\mathbf{2 1}$ a $\mathbf{3 0}$ anos & 31 anos em diante \\
\hline Masculino/Feminino & 6 & 2 & 4 \\
\hline Feminino/Feminino & 11 & 1 & 2 \\
\hline Masculino/Masculino & 1 & 2 & 1 \\
\hline & & & \\
\hline
\end{tabular}

Tabela 1. Inquéritos digitais divididos por categorias sociolinguísticas.

Apesar da tabela apresentada, não foi nossa intenção aqui levar em consideração as variáveis sociais faixa etária e sexo dos informantes, e sim os aspectos pragmáticos e conversacionais envolvidos nos diálogos estabelecidos. Procuramos garantir, porém, que houvesse ao menos uma representação em cada célula social.

Partindo da premissa de que a conversação digital apresenta uma estreita relação entre fala e escrita, por meio do texto falado por escrito, e postulando a hipótese de que algumas estratégias conversacionais próprias da fala são utilizadas no momento de interação eletrônica, acrescendo-se de outras inerentes ao meio digital, levantamos algumas questões, que foram norteadoras para nosso trabalho de investigação:

a. Como se configura a estrutura organizacional das conversações digitais?

b. Existe turno conversacional na conversação digital?

c. Como se configura o tópico discursivo nas conversações digitais?

d. Quais os marcadores conversacionais próprios da conversação digital, e quais são adaptados da conversação prototípica para o meio eletrônico?

e. Existe o fator "correção" nesse tipo de conversação? 
f. Que formas de tratamento são utilizadas nas conversações digitais?

g. Existem estratégias de Cortesia Verbal e Preservação de Faces na conversação digital? Quais seriam?

Buscamos, então, neste trabalho, testar as ferramentas já existentes de análise conversacional, ao passo que, indubitavelmente, será necessário o desenvolvimento de outras que deem suporte ao novo gênero de produção verbal em que o homem está produzindo no século XXI. A base para essa busca de novas ferramentas estará fundamentada na Análise da Conversação de linha etnometodológica e na Sociolinguística Interacional.

Dessa forma, procuramos oferecer novas possibilidades de análise para este objeto de estudo inovador, um gênero de linguagem que acaba de ser (re)inventado, ou, ainda, que está em processo de construção.

Nosso trabalho divide-se em cinco capítulos. No primeiro capítulo, apresentamos alguns estudos em Análise da Conversação, partindo de seus aspectos históricos, e sua aplicabilidade na análise das conversações digitais. Tratamos da abordagem sociointeracionista para a comunicação mediada pelo computador, discutimos a questão da interação no contexto digital e refletimos sobre a questão do gênero "Conversação Digital" no continuum fala/escrita. O capítulo é finalizado com a apresentação dos comunicadores instantâneos e suas características técnicas.

No segundo capítulo, fazemos uma retomada teórica da organização da conversação face a face e sua estrutura, apresentando as suas principais características, baseando-os nos estudos desenvolvidos pelos pesquisadores do Projeto NURC/SP e do Projeto "Gramática do Português Falado".

No terceiro capítulo, analisamos a conversação digital, sob o enfoque teórico apresentado no capítulo anterior, verificando em que medida a organização e estrutura desta se assemelha ou se distancia daquelas consideradas na conversação face a face. Neste capítulo apresentamos a noção de "Ato Enunciativo Digital" - que se constitui em uma releitura da noção de turno; e o "Tópico Pareado", que parece ter aplicação apenas nas conversações Digitais. Algumas características próprias da organização conversacional no contexto digital também são apresentadas. 
No quarto capítulo, fazemos um percurso histórico sobre a noção de Cortesia Verbal, apresentando os principais estudos nesta linha, apresentando o princípio de cooperação de Grice (1982), a abordagem de Lakof (1973), e os postulados de Goffman (1967), que deram suporte para o tradicional modelo proposto por Brown \& Levinson (1987). Apresentamos também algumas leituras críticas e releituras (Descortesia) sobre o modelo, e apresentamos ao fim uma proposta de análise baseada nesses teóricos.

No quinto e último capítulo, analisamos as conversações digitais sob o enfoque da Cortesia Verbal, procurando aproximações e distanciamentos entre estas e a conversação prototípica. Também analisamos aspectos da descortesia, e finalizamos tecendo observações sobre a "cortesia digital".

Por fim, nosso objetivo é contribuir para estudo das conversações digitais no âmbito da língua portuguesa, particularmente nas relações dialógicas, evidenciando a necessidade de se dispensar uma atenção especial às novas formas de comunicação que a tecnologia tem oferecido ao homem nos últimos anos, preparando caminho para as novidades que não cessam de aparecer dia após dia. 


\section{CAPÍTULO I \\ Análise da Conversação e Comunicação Mediada por computador}

\subsection{Reflexão sobre estudos em Análise da Conversação}

O surgimento da comunicação pode ser considerado um marco histórico, que revolucionou a vida da espécie humana. O surgimento das línguas humanas integrou grupos, permitindo a interação social. Podemos dizer que a interação é inerente ao homem, e a comunicação é a manifestação real desse fato. Na medida em que o homem evolui, a comunicação e as formas de se valer dela também mudam, transformam, aprimoram-se. Variadas formas de comunicação sempre estiveram presentes na vida dos seres humanos. Foi e continua sendo uma das conquistas mais importantes, o fator primordial que os diferencia das outras espécies.

Uma característica humana que impulsiona o homem a valer-se da comunicação é o fato de viver em comunidade. Essa característica única do ser humano fez com que ele sempre se aventurasse em busca de novas terras e novas comunidades, tendo de se deparar com desafios comunicacionais e práticas sociais que o levaram a construir sistemas complexos de compreensão mútua, e entre eles, a conversação, talvez o mais importante e aquele de que nunca pode abdicar em sua vida.

Segundo Silva (2008), a conversação é uma prática social de que prescinde todas as outras práticas na vida social. É por meio da conversação que os indivíduos se fazem seres sociais, se relacionam com seus semelhantes e assumem seus papéis sociais, tentando desde sempre atingir seus propósitos pragmáticos. É um instrumento essencial ao homem, que Ihe possibilita realizar um trabalho cooperativo e eminentemente social.

A própria palavra conversação já traz em si, um sentido eminentemente humano, inerente à espécie. Silva (2008, p.32) faz um percurso etimológico do termo: 
... conversação é um substantivo ligado ao verbo conversar, que procede do latim conversare, encontrar-se habitualmente num mesmo local. Esse termo é composto de con (junto) e versare ( dar voltas). Remete-nos, pois, à ideia de conviver com outras pessoas. A palavra conversação deriva do latim conversatio, onis, que significa convivência, ação de viver junto.

A conversação tem em sua raiz, pois, a razão de sua existência: unir as pessoas em torno de um objetivo, que é comunicar.

Entre as diversas concepções para o termo conversação, podemos encontrar autores que a definem como qualquer interação verbal, fazendo distinção apenas entre conversação formal e informal. Outros pesquisadores, na linha de Levinson (1983, 2007), consideram a conversação como um tipo de fala do tipo espontâneo, em que não há um planejamento prévio.

Já Moreno Fernandez (1998) define a conversação como um tipo de comunicação falada que se caracteriza pelo aspecto dialógico em oposição ao monológico, enquanto Hilgert $(1989$, p.82) entende a conversação como uma atividade prática e cotidiana, e seu desenvolvimento depende da auto-organização patrocinada interacionalmente pelos interactantes.

Assim, os interlocutores são sujeitos da conversação e desenvolvem o processo conversacional por meio da interação. Quando a interação verbal é realizada, "um sistema de práticas, convenções, regras de comportamento é empregado" (GOFFMAN:1970, p.10).

Esse sistema corresponde a uma série de elementos: normas sociais, regras de conduta, etiqueta, tipo de norma linguística adequada a cada situação discursiva, entre outros.

Consideramos, neste trabalho, a conversação como um fenômeno social que, tanto como contribui para a reprodução e transformação das estruturas sociais, como é transformada por elas. A conversação é uma ferramenta indispensável para a comunicação entre os falantes e para que estes possam se posicionar de maneira crítica em seu próprio mundo. 
A tomada da conversação como um objeto de estudo remonta à década de 60 , quando foram empreendidas pesquisas pelos americanos H. Sacks, E. Schegloff e G. Jefferson (1974), iniciadores da disciplina que ficou conhecida como Análise da Conversação de linha etnometodológica.

É importante estabelecer uma distinção entre Análise do Discurso e a Análise da Conversação, uma vez que as duas disciplinas analisam estruturas conversacionais, sob diferentes enfoques (objetivos, metas e metodologias).

A Análise do Discurso, surgida nos anos 60, desenvolveu-se com Malcolm Coulthard e Michel Stubbs, caracterizando-se por utilizar os princípios da linguística teórica em suas análises. A coerência e a coesão dos discursos eram os focos de suas pesquisas.

A Análise da Conversação, por sua vez, teve seu desenvolvimento a partir dos preceitos da Etnometodologia, com Sacks, Schegloff e Jefferson, que, em suas análises, focalizaram dados empíricos, de aspecto qualitativo, indutivo, baseando-se em conversações naturais.

Foram os sociólogos (também conhecidos como etnometodólogos) os primeiros a se preocupar com a questão, propondo um ponto de vista qualitativo para o processo interacional, diferente da visão quantitativa presente entre os pesquisadores americanos naquele momento. Por este motivo, é uma ciência que tem como eixo orientador o trabalho com dados empíricos, analisados em seu real contexto de ocorrência, qualitativamente. É importante lembrar que a Análise da Conversação é transdisciplinar desde as suas origens, tendo como atores filósofos, sociólogos, antropólogos, psicólogos, linguistas, etnolinguistas, entre outros.

Até meados da década de 70, a Análise da Conversação preocupou-se em descrever a estrutura da conversação, bem como os mecanismos que a organizam durante o processo de interação entre os interlocutores.

É interessante ressaltar que naquele momento, acreditava-se que a ação e interação social pela linguagem deviam ser estudadas e descritas numa estrutura convencionalizada e institucionalizada. (cf. MARCUSCHI:2001). A preocupação recaía, dessa forma, sobre a questão dos turnos, elementos de início e término dos contatos interativos, saudações, perguntas e respostas, convites e aceitações/recusas, entre outros; deixando de lado 
questões habitualmente levadas em consideração pela Sociologia. Esse fato a levou a ser considerada por muitos um campo autônomo, distinto da Etnomedologia.

A palavra Etnometodologia combina os termos etno, referente aos conhecimentos comuns que cada indivíduo possui acerca da sociedade, e metodologia diz respeito às atividades cotidianas, práticas sociais de conhecimentos comuns.

A Etnometodologia surgiu a partir de estudos fenomenológicos iniciados principalmente por H. Garfinkel, seguido de G. Jefferson, H. Sacks e E.Schegloff, entre os anos 50 e 60 nos Estados Unidos. Garfinkel, neste momento, rompia com a Sociologia tradicional, excessivamente numérica e objetiva, quantitativa.

Sua preocupação não recaía exclusivamente sobre os elementos linguísticos das interações verbais, mas analisavam " as atividades de todos os dias como se fossem métodos que os membros utilizam para tornar essas atividades, visivelmente, racionais e referenciáveis a qualquer objetivo prático, isto é, descritíveis". (GARFINKEL apud COULON:1995, p. 19-20).

Coulon (1995) esclarece que, apesar dessa aparente distinção, a Análise da Conversação pode ser considerada o programa mais avançado da Etnometodologia, o campo mais rico e mais desenvolvido. Vários fatores podem ser citados para comprovar essa afirmação, entre eles o fato de que vários princípios teóricos e metodológicos da Etnometodologia passaram a ser usados pela Análise da Conversação.

Os fatos sociais são considerados realizações práticas promovidas por meio do convívio social dos indivíduos e não são utilizados como fonte para o estudo de modelos preestabelecidos, mas como caminho para surgimento de uma metodologia empírica. A partir da análise da realidade e do comportamento social, procura-se estudar "os procedimentos que os membros de uma sociedade utilizam para interpretar as ações sociais cotidianas que constituem a realidade" (SILVA:2008). Enquanto a Sociologia tradicional estuda fatos sociais já realizados, a Etnometodologia estuda os fatos no momento em que acontecem.

Silva (2008, p.38) apresenta três aspectos básicos da Etnometodologia: estuda as atividades práticas do cotidiano; apresenta caráter empírico; e apresenta um princípio de organização. 
Os estudos etnometodológicos tomam acontecimentos triviais e práticas sociais correntes como objetos de estudo e reflexão. Diferente da Sociologia Tradicional, que tem na objetividade dos fatos seu princípio primordial, a Etnometodologia vê o fato social como aspecto fundamental. Estuda as atividades práticas cotidianas, que são concebidas como processos, de forma estruturada, ordenada. Analisa minuciosamente os fatos concretos que são partes integrantes da arquitetura social.

O aspecto empirista das pesquisas desenvolvidos pelos etnometodólogos oferece à Análise da Conversação uma vocação naturalística em que prevalecem as descrições e interpretações qualitativas, prevalecendo sobre as quantitativas.

Marcuschi (op.cit, p.08) afirma que a Análise da Conversação estabeleceu, desde o início, sua preocupação básica com a vinculação situacional, com o caráter pragmático da conversação e toda a atividade linguística diária, em que o contexto assume um papel importante para a concatenação das práticas sociais de linguagem. Nesse processo, os próprios atores fornecem ao analista as evidências das atividades por eles desenvolvidas.

A Análise da Conversação de linha etnometodológica surgiu com os estudos de Harvey Sacks, tendo como eixo norteador a organização social da conduta cotidiana em uma sociedade. Silva (2008, p.41) explica que:

\footnotetext{
...quando [Sacks] era aluno de Erving Goffman na Universidade de Berkeley, chegou a conhecer Harold Garfinkel em 1959, durante um ano sabático deste último em Harvard. Sacks encontrou alguns pontos comuns entre os seus estudos e os de Garfinkel e passou a manter contatos com ele. De certo modo, nasciam assim os estudos de Análise da Conversação de linha etnometodológica.
}

Assim sendo, o foco das investigações propostas por Sacks e sua equipe recaem sobre a organização da conduta significativa de pessoas na sociedade. Sua atenção não estava voltada à conversação, mas à forma como os indivíduos realizam suas ações sociais e dão sentido ao mundo à sua volta, como dão sentido às ações que executam empiricamente.

As investigações empreendidas pelos etnometodólogos possibilitaram à Análise da Conversação a aquisição de competência científico-metodológica capaz de lidar com a linguagem de forma mais objetiva e criteriosa; fato este que possibilita hoje ser considerada 
uma ciência linguística capaz de investigar enunciados realizados em situações empíricas. Essas investigações objetivam refletir sobre os conhecimentos práticos da sociedade, em eventos próprios da vida em sociedade. A Análise da Conversação de linha etnometodológica tem preocupação pragmática pelo uso da linguagem, pelas condições de enunciação.

Passado o primeiro momento em que as preocupações da Análise da Conversação se voltavam para a estrutura da conversação, que revelavam, segundo se acreditava, as atividades sociais dos agentes sociais, houve uma maior preocupação com um estudo mais apurado dos aspectos linguísticos do texto falado. Marcuschi $(2001$, p.06) esclarece que os estudos nesta direção evocam investigações que procuram verificar como se configuram a organização da conversação e a interação bem-sucedida entre interlocutores num ato comunicacional.

Para tal, leva em consideração conhecimentos compartilhados entre os interlocutores no ato conversacional, sejam eles linguísticos, gestuais ou contextuais, observando-se sempre as características inerentes a cada evento social. A atividade de enunciação é evidenciada, pois há um interesse maior pelas questões linguísticas e pragmáticas.

Silva (2008, p.43) esclarece que a Análise da Conversação preocupa-se com a vinculação situacional e com o caráter pragmático da conversação. Essa perspectiva faz com que os analistas da conversação recusem a construção de teorias prematuras e idealizadas de materiais investigados, preferindo dedicar-se à análise profunda e qualitativa dos dados empíricos.

A Análise da Conversação segue um método indutivo, pois não existem modelos prontos a serem seguidos. Os dados empíricos são privilegiados, por isso não se aceitam materiais extraídos de fontes literárias, filmes, peças de teatro e outras fontes artificiais.

As análises geralmente estão voltadas para explicar as estratégias e ações interativas realizadas pelos interlocutores, bem como os meios utilizados para que suas necessidades comunicacionais sejam atingidas no processo interacional real. Evidenciam-se nas análises as estruturas, o funcionamento e o mecanismo conversacional, tentando apontar as regularidades, que, por sua vez, exibem mecanismos singulares de atividades sociais. 
A conversação passa, então, a ser analisada como um processo de cooperação entre agentes sociais, dando espaço para as preocupações com a ação e interação sobre a linguagem.

\subsection{A Análise da Conversação e a Conversação Digital}

Não restam dúvidas de que a Internet constitui, nos dias de hoje, o maior sistema de comunicação que o homem já desenvolveu depois do evento da interação verbal. Pode ser definida, grosso modo, como um conjunto de redes de computadores interligadas, com usuários que compartilham serviços de informação e comunicação de forma global.

Com a entrada definitiva da Internet conectando pessoas no mundo inteiro, as condições de produção e divulgação de conhecimento, bem como as formas de comunicação conheceram novas dimensões.

Uma das qualidades inerentes à Análise da Conversação de linha etnometodológica é o fato de evitar a construção de modelos, e desenvolver uma forma de análise primordialmente empírica, indutiva. Sendo assim, a Análise da Conversação tem a propriedade de adaptar-se e adequar-se a uma diversidade muito grande de objetos de estudo conversacionais. A conversação digital é assumida aqui, então, como objeto de pesquisa nesta linha de investigação.

A conversação digital apresenta uma estreita relação entre fala e escrita, por meio da realização escrita do texto falado. Nele, as estratégias conversacionais próprias da fala são utilizadas no momento de interação eletrônica, porém, ocorre a utilização de recursos próprios ao meio utilizado (HILGERT:2000). O ponto de partida é o estudo do processo interacional na Internet tendo em vista estratégias utilizadas entre interlocutores em contextos de contato linguístico.

Firmino (2005, p.39) afirma que "o advento da Comunicação Mediada por Computador (CMC) não veio aniquilar o desejo comunicativo do ser humano, outrossim, apenas vem reforçando, colocando num patamar diverso do tradicional, o hábito milenar de conversar, conquanto tenhamos encarnado no meio eletrônico a faceta mais notória e livre da conversação: o bate-papo."

Na Análise da Conversação, o comportamento verbal dos interlocutores durante o processo interativo é descrito compreendendo-se como se configura a organização do ato 
conversacional. Os pressupostos para uma análise conversacional incluem a observação de algumas características inerentes ao processo interativo, como a situação, as características dos participantes da interação em foco e as estratégias utilizadas durante o diálogo (BRAIT:1993, p.193).

Para tal, consideraremos as conversações eletrônicas ocorridas nos serviços comunicadores instantâneos, no programa MSN, tentando estabelecer convergências e divergências entre a conversação face a face e a conversação digital, ou, em outras palavras, como o processo se transfere do plano "físico" para o virtual-real, traçando assim um caminho inicial para uma futura pesquisa mais aprofundada.

Assim, neste trabalho, procuramos identificar, descrever e analisar as estratégias interacionais que envolvem a conversação digital na Internet. Buscamos o embasamento na perspectiva da Análise da Conversação, e tentamos abarcar o universo do "texto falado por escrito" na Internet.

Concordamos com Crescitelli (1997:22), segundo a qual "não é o domínio de métodos preestabelecidos que constitui a competência do analista, mas, antes, a sua sensibilidade para observar os fenômenos interacionais, sua estrutura e organização." Apesar de ser um fenômeno atual, próprio do mundo moderno, já muitos estudiosos se debruçam sobre os enunciados trocados na internet, de uma forma geral.

Araújo (2004) trata da transferência do diálogo cotidiano de sua esfera de origem (face a face) para a conversação em tempo real ocorrida nos chats. A hipótese levantada pelo pesquisador é de que é possível flagrar as marcas desta transmutação, a partir do estudo das semioses som-imagem-escrita que se materializa no Chat, tendo como referência a abordagem teórica bakhtiniana.

Afirma que, na Internet, parecem existir três maneiras de interagir numa conversação em tempo real: IRC, ICQ e o chat na web. Em seguida, passa a caracterizar cada tipo, analisando, ao final, os chats na web.

Hilgert (2000) aborda a conversação na Internet, e focaliza especificamente o "batepapo" ou chat. Segundo Hilgert, nesse tipo de interação, os interlocutores estão em contato por um canal eletrônico, o computador, e sentem-se falando, mas, pelas especificidades do meio que os põe em contato, são obrigados a escrever suas mensagens, construindo assim 
"um texto falado por escrito". O objetivo do texto, segundo o pesquisador, é discutir estratégias de construção do texto conversacional na Internet, tendo como referência os estudos sobre conversação face a face.

Num primeiro momento, Hilgert discute as relações de escrita e fala na perspectiva de um continuum tipológico da produção textual. Num segundo momento, passa à configuração do objeto de análise, descrevendo de forma sutil as especificidades da conversação na Internet. Trata da alternância de turnos na conversação digital, aplicando as regras de distribuição de turnos. Trata também da formulação linguística e passa às discussões finais. Conclui que a marca da construção de textos na Internet é a interatividade. Segundo ele, os interlocutores querem interagir. Impelidos a escrever, os interlocutores ressignificam a escrita, num processo de retextualização da oralidade.

Firmino (2005) analisa as formas associativas existentes nos chats (bate-papos), e afirma que “...o advento da Comunicação Mediada por computador (CMC) não veio aniquilar o desejo interativo do ser humano, outrossim, apenas vem reforçando (...)o hábito milenar de conversar"(p.39) Neste texto, o autor reflete sobre algumas formas associativas existentes nas salas de bate-papo: a interação em massa, a interação com subgrupos e as interações duais.

Há ainda, entre os estudiosos que se debruçaram sobre o assunto, Chaves (2001), Nader(2001), Mccleary(1996), Barros (2001), entre outros.

\subsection{Abordagem Sociointeracionista e a comunicação mediada por computador}

A Sociolinguística Interacional se ocupa em decifrar questões discursivas e interacionais que envolvem o efetivo exercício da linguagem, numa dada situação real. Tem dispensado especial atenção à linguagem em uso na comunicação, analisando profundamente a constituição, as regras e convenções presentes nas conversações, bem como os contextos em que se realizam as condições segundo as quais os indivíduos agem em determinadas situações de fala.

Segundo Garcez (2008, p.01), 


\begin{abstract}
"A Sociolinguística Interacional tem interesse em responder perguntas do tipo "o que está acontecendo aqui", neste cenário de ação humana, do ponto de vista dos participantes. Portanto, se interessa pela ação humana mediante o uso da linguagem e trata de examinar situadamente o que as pessoas estão fazendo umas com as outras. Assim, estamos interessados em ações realizadas no uso da linguagem".
\end{abstract}

A abordagem sociointeracionista procura analisar a maneira como os interlocutores constroem o discurso e o manipulam em um determinado contexto, como constroem e manipulam aspectos pragmáticos durante a interação. Para os estudos interacionais, o contexto é uma forma de práxis interacionalmente constituída. Assim, na Sociolinguística Interacional, contexto é "conhecimento" e "situação".

Gumperz (1982a), ao abordar a questão das convenções de contextualização, trata das pistas de natureza sociolinguística que o falante usa para sinalizar os seus propósitos comunicativos, ou para inferir os propósitos do seu interlocutor. São pistas linguísticas (dialetos, alternância de código, dialeto ou estilo), pistas paralinguísticas (valor das pausas, tempo da fala, hesitações, etc.) e/ou pistas prosódicas (entoação, acento, tom, etc); todos sistemas socialmente estabelecidos. Pistas não verbais, como o olhar, o distanciamento entre os interlocutores, suas posturas também são levados em consideração.

Dentro de um contexto digital, nas conversações mediadas por computador, uma análise da organização do discurso e da interação social na internet torna-se eminentemente necessária, uma vez que deve desvendar o sistema de conversação digital.

O processo de inferência conversacional também é evidenciado na análise, uma vez que coloca, no centro da investigação teórica, os traços linguísticos contextuais que, até o momento, eram considerados marginais ao sistema linguístico.

Para as análises das conversações mediadas por computador, esse processo de inferência é importante, uma vez que é sempre de natureza sugestiva, nunca assertiva, baseado em pressuposições; são situações de compreensão hipotéticas sobre os propósitos comunicativos.

Nas conversações digitais, esse processo é muito evidente, pois o interlocutor interpreta as mensagens recebidas na tela de seu computador em termos de conhecimento 
pressuposto, nunca em termos de valores absolutos, exatamente como ocorre nas situações reais de fala face a face. É importante ressaltar que esse conhecimento pressuposto ou "conhecimento de mundo" é reinterpretado na conversa digital, e é construído social e interacionalmente.

A análise do processo comunicacional das conversações digitais, do ponto de vista sociointeracionista, é possível, à medida que informações internalizadas pelos agentes sociais são evidenciadas no momento da interação via MSN.

Submetemos, aqui, as conversações digitais "à análise dos critérios interativos pelos quais os participantes negociam as interpretações". (GUMPERZ:1982a, p.130) Variáveis linguísticas digitais são analisadas, dentro de uma perspectiva macro-social, com o intuito de descobrir como elas contribuem para a interpretação do que está sendo feito na interação comunicativa.

Dentro desta perspectiva, consideramos aqui as pistas de contextualização sugeridas por Gumperz. Elas podem ser entendidas como "constelações de traços presentes na estrutura de superfície das mensagens que os falantes sinalizam, e os ouvintes interpretam qual é a atividade que está ocorrendo, como o conteúdo semântico deve ser entendido e como cada oração se relaciona ao que a precede ou sucede"² (op. cit, p.131).

As pistas de contextualização são traços linguísticos que contribuem para a sinalização de pressupostos contextuais. Segundo o pesquisador, essas pistas podem aparecer sob várias manifestações linguísticas, dependendo do repertório linguístico, historicamente determinado a cada participante.

O autor esclarece que, embora essas pistas sejam portadoras de informação, os significados são expressos como parte do processo interativo, ao contrário de palavras, que podem ser discutidas fora do contexto. O valor do sinalizador depende do reconhecimento mútuo desse significado por parte dos participantes.

Na conversação digital, essas pistas podem ser consideradas:

a) abreviações;

b) emoticons;

c) alternância de Caixa Alta e Caixa Baixa.

\footnotetext{
2 "...constellations of surface features of message form are the means by wich speakers signal and listeners interpret what the activity is, how semantic content is to be understood and how ech sentence relates to what precedes or follows."
} 
d) repetições de letras;

e) pausas, sinais, reticências e outras referências gráficas.

f) etc.

Salientamos que, quando o interlocutor não reage a uma das pistas, ou não conhece sua função, pode haver divergências de interpretação e mal-entendidos na conversação digital. Gumperz afirma que "quando isso acontece (...) há uma tendência a reações em termos de uma questão de postura ou atitude. Dizemos que o falante é antipático, impertinente, grosseiro, não cooperativo, ou que não está entendendo". (p.152) Erros deste tipo são comuns no $M S N$, e são considerados gafes ou falta de compreensão do interlocutor quanto ao conteúdo da mensagem.

\section{4 Sociedade, Cibercultura e Comunicação Digital}

A sociedade pode ser concebida como um grupo organizado de pessoas que compartilham propósitos, gostos, preocupações e costumes, e possuem, como elemento de ligação a interação entre si, constituindo comunidades. É uma rede de contatos organizada por interesses comuns os mais diversos: língua, trabalho, preferências, estudos, entre outros elementos. Ao viver em sociedade, nesta rede de relações e interações, o homem cria e recria o que se chama de cultura: as transformações que faz em seu meio, em seu domínio.

A cultura serve ao homem para que este se sinta parte do mundo, uma vez que representa tudo o que é aprendido e partilhado pelos indivíduos de um determinado grupo e que confere uma identidade dentro do seu grupo.

A Cibercultura surgiu da relação estabelecida entre a tecnologia eletroeletrônica e a modernidade, sendo que esta última teve suas bases no domínio da natureza pelo homem. No contexto da Cibercultura, há também uma busca pela dominação; não física, mas sobre o domínio das formas de manifestação dessa cultura para poder agir virtualmente e manipulá-la, para conhecê-la, num primeiro momento, e transformá-la.

Essa transformação pretendida se dá no âmbito das facilidades previstas para a futura manipulação humana de dados, seja por meio da internet (computadores, celulares, etc), automatização informatizada ou por meio de equipamentos para tratamento científico (genoma humano, simulações diversas, engenharia genética, etc). 
Dentro deste contexto, e com a chegada da internet estabelecendo novas formas de contato e um tipo de comunicação globalizado, passou-se a usar o termo cibercultura para designar ações produzidas pelos homens em suas incursões no mundo digital. Podemos entendê-la como um fenômeno sociocultural que se instaurou na década de 70 , por meio das interações e trocas entre a sociedade, a cultura e as novas tecnologias digitais que permitiram a aproximação dos fatos sociais ao contexto eletrônico.

A comunicação pela internet tem ocupado um lugar cada vez maior na sociedade global. A sociedade tem encontrado, nas novas tecnologias, formas diferenciadas de produzir e entender a cultura. Esse fato se dá por ser o ciberespaço o lugar mais vasto e mais frequentado do mundo contemporâneo.

A comunicação mediada pelo computador possui a característica essencial de não possuir marcas de nacionalidade. Ao se ter acesso a uma página na rede, ou mesmo quando se lê uma mensagem de uma pessoa numa rede social, ou lista de discussão, o país e o idioma de quem as escreveu não são imediatamente aparentes e nem importantes. A comunicação escrita livra os usuários de serem rotulados por seu sotaque, cor de pele, religião, etc.

Diante desta situação, um mundo virtual, novo e inexplorado ainda nasceu, entre o utópico e o real. Segundo Lévy (2007), esse novo mundo tem desterritorializado a biblioteca, tomando lugar como um novo tipo de relação com o conhecimento.

A informação que antes era limitada a um grupo de pessoas, passou a se desenvolver de forma espantosa, adquirindo contornos significativos em decorrência do seu processamento por meio dos meios de comunicação social. As pessoas estão cada vez mais descobrindo na internet uma maneira rápida e eficiente de entrar em contato com pessoas de outros países ou, até mesmo, de conhecer aspectos culturais e sociais de várias partes do planeta. A rede mundial de computadores quebra barreiras e, cada vez mais, liga as pessoas e espalhando as ideias.

Com relação a essa nova forma de conhecimento, Benedito (2002) afirma que "através de uma dinâmica espiral, parece regressar-se, nele, até à oralidade da origem, em que o saber era carregado por comunidades humanas vivas, nascendo assim novas formas de inteligência coletiva" (p.5) 
A autora entende que, diferente da Babel que confundiu as línguas, o ciberespaço ensaia o estabelecimento de uma forma de comunicação global e comum a todos, uma língua comum, em que espaço e tempo são vencidos completamente, pois, neste ciberespaço, há lugar para qualquer pessoa, todas as situações e ritmos.

Enfim, o ciberespaço é um lugar virtual onde as pessoas podem encontrar-se para conversar online e em tempo real sobre variados temas. Podem, se desejarem, estabelecer comunicação ao sabor da corrente da conversa que, muitas vezes, se resume a muitas manifestações de trocas de saudações de entradas, de despedidas, ou mesmo assuntos relacionados às condições climáticas em cada parte do globo onde os utilizadores se encontram...(op.cit. p. 09)

A interação é total, livre, e pode-se participar, partilhar, comentar, numa situação de reciprocidade, interação, de maneira ininterrupta, direta, e, muitas vezes, coletiva. Diante de toda essa liberdade, o ciberespaço, lugar cada vez maior e mais ocupado pela comunicação eletrônica, merece especial atenção por parte dos pesquisadores das ciências em geral e, principalmente, das ciências humanas, uma vez que este é o lugar mais vasto e mais frequentado do mundo atualmente.

Viver sem o acesso à rede está cada vez mais difícil, quer pelas inúmeras possibilidades que esta oferece, quer pelo oferecimento constante de produtos e serviços que bancos, universidades e outras entidades e instituições oferecerem. Muitos serviços bancários, aliás, hoje em dia, só podem ser acessados via "Internet Banking", por exemplo.

Acompanhando as ideias de Lévy (2007), pode-se afirmar que um novo mundo virtual emergiu, se instaurou entre o imaginário e o real, o utópico e o verdadeiro. Houve, dessa forma, a desterritorialização da biblioteca, colocando-se como um prenúncio de novas formas de lidar com o conhecimento.

Do ponto de vista da Comunicação, a cibercultura vem como uma possibilidade inovadora de libertar o homem de suas limitações de tempo e espaço. Por meio da tecnologia, é possível navegar, conhecer lugares, conhecer novas ideias e pesquisar assuntos diversos, que não poderiam ser vistos ou conhecidos se não estivessem disponíveis na rede da cibercultura. Em se tratando de práticas sociais, pode-se dizer que a Cibercultura se 
caracteriza também, e fundamentalmente, pela apropriação social-midiática (informática, internet e as atuais práticas das redes sociais ) da técnica de comunicação.

\subsection{A interação e a comunicação na Internet}

Nos dias atuais, a Internet constitui certamente o maior sistema de comunicação que o homem já desenvolveu. Com o surgimento da World Wide Web (sistema www, para acessar páginas remotas), em meados de 1980, a Internet se tornou ainda mais poderosa. Formou-se uma rede de computadores interligados que fornecem informações mutuamente em forma de hipertexto, que são textos nos quais se encontram ligações (links) para outras páginas. Com essa ferramenta, incorporaram-se imagens e sons à rede.

A Internet se tornou, então, um conjunto de redes de computadores interligadas, de forma que os usuários compartilham serviços de informação e comunicação de forma global. Juntamente com toda essa evolução, desde os primeiros momentos, houve o surgimento de meios de comunicação digital.

Segundo Marcuschi (2004, p.13), “...pode-se dizer que, na atual sociedade da informação, a Internet é uma espécie de protótipo de novas formas de comportamento comunicativo".

Primeiro veio o e-mail, em meados de 1960, e desde então os meios de comunicação eletrônicos foram se aprimorando, até o surgimento de diversos comunicadores instantâneos. Os mais conhecidos, atualmente, são o ICQ e o MSN.

São aplicações que permitem o envio e recebimento de mensagens de texto em tempo real. Por meio desses programas, o usuário é informado quando algum de seus amigos, cadastrado em sua lista de contatos, é conectado à rede. A partir daí, eles podem manter conversações por meio de mensagens de texto - ou até som e imagem.

Normalmente, esses programas incorporam diversos outros recursos, como envio de figuras ou imagens animadas, conversação em áudio - utilizando as caixas de som e microfone do sistema, além de vídeo conferência. Inicialmente, possibilitavam a conversação entre dois interlocutores apenas, mas hoje suportam diversos interlocutores ao mesmo tempo. Outra forma de manter essas conversações digitais é por meio dos chamados 
"bate-papos" ou "chats", oferecidos por sites em diversos pontos da rede. Entre os mais conhecidos estão o UOL, YAHOO e BOL.

O bate-papo também permite uma conversa em tempo real entre diversas pessoas, em ambientes remotos, por meio de mensagens escritas e/ou sonoras. É dividido em salas temáticas, permitindo que usuários com interesses comuns possam trocar ideias e informações acerca do tema escolhido. Também tem sido utilizado para ensino à distância, entretenimento, transmissão de eventos, suporte para clientes em empresas, entre outros.

Essa revolução interacional e comunicacional motivou estudos científicos na área da linguagem que se tornam cada vez mais relevantes. Dentre esses estudos, destacam-se os trabalhos de Hilgert(2000), Barros(2001), Marcuschi(2002), Chaves (2001), Araújo (2004), Crystal (2005), Erickson (1997,2000), Mccleary(1996), dentre outros.

Os trabalhos são desenvolvidos a partir das mais diversas facetas semióticas da Internet, e preocupam-se em estudar mecanismos que estruturam textos orais e escritos na rede.

Galli (2004) analisa a linguagem da Internet como um meio de comunicação global. Segundo ela, a comunicação virtual introduz um conceito de descentralização da informação e do poder de comunicar. A autora afirma que a Internet é um meio de comunicação que proporciona a interação entre locutor e interlocutor, uma vez que, na rede, qualquer elemento adquire a possibilidade de interação, havendo interconexões entre pessoas dos mais diferentes lugares do planeta, facilitando, portanto, o contato entre elas. (p.124).

Xavier \& Santos (2005) tratam o gênero fórum, analisando as funções interacionais do Fórum Eletrônico (FE). Afirmam que "em meio às muitas respostas que surgem nos vários FE's distribuídos pelos diversos sites e portais da Internet, encontram-se também variadas e surpreendentes ações discursivas..." (p. 31)

Os autores dizem que apenas uma parcela dos participantes se atém de fato à questão central em discussão, desobedecendo ao princípio de relevância para as interações proposto por Grice(1980). Os pesquisadores encontraram interações em que os participantes aproveitavam a oportunidade para fazer piadas, ironias, correntes, desabafos, ataques pessoais, críticas ao governo, breves ensaios acadêmicos, protestos em geral, entre outras atitudes comunicativas. 
Os autores acreditam que a multiplicidade de ações de linguagem manifestas no FE não o faz perder sua característica essencial: promover a discussão em torno de uma questão social controversa e de servir como instrumento de reflexão e construção coletiva para a solução de um dado problema. (p.35)

Marcuschi (2004) analisa as características fundamentais dos gêneros textuais que estão emergindo nos ambientes virtuais. Segundo o autor, "na atual sociedade da informação, a Internet é uma espécie de protótipo de novas formas de comportamento comunicativo." (p.13)

O pesquisador atribui o sucesso e o amplo uso do meio ao fato de reunir num só canal várias formas de expressão, tais como texto, som e imagem, o que dá maleabilidade para a incorporação simultânea de múltiplas semioses, e interfere na natureza dos recursos linguísticos utilizados.

Marcuschi ressalta um aspecto importante em relação à tecnologia: diferente do que muitos pensam, a natureza das novas tecnologias não é antissocial, mas favorece verdadeiras redes de interesses. Existem muitas "comunidades virtuais", em que os membros interagem de forma rápida e eficaz.

O autor diferencia seis dimensões de interação digital, que podem ser assim representadas:

1) Ambiente WEB (ambiente de buscas de todos os tipos, descentralizado, interativo e passível de expansão ilimitado).

2) Ambiente EMAIL (Meio de comunicação interpessoal com remessa e recebimento de correspondência).

3) Foros de Discussão Assíncronos (ambiente de discussão para temas específicos, movidas por interesses comuns).

4) Ambiente Chat Síncrono (trata-se dos ambientes em salas de bate-papos entre várias pessoas simultaneamente ou em ambiente reservado.

5) Ambiente MUD (São ambientes interativos para jogadores);

6) ambientes de áudio e vídeo (Videoconferências). 
Todo e qualquer evento comunicacional envolve, por natureza, uma interação, entendida aqui como um envolvimento mútuo entre "interactantes" que exercem uns sobre os outros uma rede de influências mútuas (ORECCHIONI:2006, p.08), por meio de trocas simbólicas, verbais e não verbais. Na interação verbal, os interactantes tendem a ajustar, coordenar e harmonizar permanentemente seus comportamentos pragmáticos.

Segundo Orecchioni, não basta simplesmente que os interlocutores falem alternadamente, mas que falem entre si, engajando-se numa troca pragmática, dando claros sinais desse engajamento por meio de procedimentos de validações interlocutórias (cumprimentos, rituais confirmativos, procedimentos fáticos, reguladores, entre outros).

Assim, podemos falar em diferentes tipos de interações verbais: conversações familiares, as conversas de todos os gêneros, as entrevistas, os debates, as transações comerciais, as trocas didáticas, os encontros científicos, as reuniões de trabalho, entre outras.

\subsection{A conversação digital num continuum fala/escrita: a questão do gênero}

O desenvolvimento das novas tecnologias e a consolidação dos meios eletrônicos digitais como instrumentos de comunicação trouxeram à vida cotidiana do homem inúmeras ferramentas de interação inovadoras por meio da Internet. Segundo Machado (2002, p. 119), “...a interação não é exclusividade da linguagem natural, mas diz respeito também às linguagens artificiais, que se tornam, assim, produtoras de gêneros".

Os gêneros digitais se caracterizam pelo contexto digital em que estão inseridos, ou seja, pelas formas comunicativas processadas digitalmente ou pela via on-line, pela conexão e estrutura de computadores. Caracterizam-se, dessa forma, por arquiteturas computacionais modelizadas por linguagens artificiais, criadas pela engenharia digital, para combinação e reprocessamento de sistemas de escrita e de gêneros literários, discursivos, de gêneros informativos da mídia impressa, da linguagem visual, dos gêneros audiovisuais, entre outros. (MACHADO:2002)

O surgimento dos gêneros digitais trouxe consigo uma nova atitude também diante da linguagem e da conversação como um todo: esta seria realizada em tempo real, mas mediada pelo computador e essencialmente por escrito. 
Seria necessário, então, escrever a mensagem a ser enviada. Isso exigiria rapidez e dinamicidade por parte do "falante-digitador", pois o interlocutor estava em um outro ponto da rede, esperando o retorno de seu contato.

Na verdade, segundo Hilgert (2000, p.17), os interlocutores, que estão em contato por um canal eletrônico, sentem-se falando, mas, pelas especificidades do meio que os põe em contato, são obrigados a escrever suas mensagens. Interagem, assim, construindo um texto "falado por escrito".

E essa é, segundo já evidenciamos anteriormente, a perspectiva inicial que guiará esta pesquisa, a premissa de um texto falado por escrito em que os interlocutores utilizam estratégias conversacionais próprias da língua falada, numa integração clara entre os dois tipos de linguagens.

Segundo Marcuschi(2008), a escrita “... permeia hoje quase todas as práticas sociais dos povos em que penetrou. Até mesmo os analfabetos, em sociedades com escrita, estão sob a influência do que se convencionou chamar de práticas de letramento..."(p.19)

Não há como fechar os olhos para os eventos de letramento em nossa sociedade. Vivemos em um mundo imerso em atividades que exigem dos interactantes práticas sociais que envolvem a escrita: desde o pagamento de um produto usando cédulas com valores diferenciados até a utilização de ônibus com destinos diferentes, apenas "sinalizados" por meio da escrita. Mesmo pessoas não escolarizadas, para terem sucesso em nossa sociedade, adaptam-se a essa realidade e conseguem agir com relativa tranquilidade em meio a esse mar de informações impressas em rótulos, em placas, etiquetas, documentos, entre outros.

No que tange à conversação digital, acreditamos ser esta um gênero emergente do meio digital, e perpassa uma linha tênue entre oralidade e letramento, este último entendido quanto às práticas sociais que se fazem da língua em situação de uso real. Ressalta-se que o letramento não pode ser confundido com alfabetização, ou domínio da escrita, uma vez que este possibilita uma "leitura" que vai além da escrita. Faz parte da leitura de mundo que todos fazem em seu convívio diário, em todas as instâncias da vida social.

Por outro lado, no que se refere à prática da conversação digital, diferente do fenômeno da fala espontânea, que não requer conhecimentos do código escrito 
propriamente dito, esta prática necessita de que seus interlocutores dominem as técnicas básicas de escrita e leitura do ponto de vista de aquisição do código, uma vez que a interação se dá pela modalidade escrita.

A oralidade representa uma prática social interativa que serve à comunicação em diversas situações e gêneros, fundados, segundo (MARCUSCHI:2008), numa realidade sonora. O letramento, dentro desse contexto, está ligado às práticas sociais quanto ao uso da leitura e escrita ( nas mais variadas formas), desde o reconhecimento de símbolos (marcas, valor do dinheiro, ônibus a serem "tomados", por pessoas não-alfabetizadas) até a escrita de tratados científicos.

Essas distinções estão fundadas nas práticas sociais que fazemos da língua. Segundo essa perspectiva, "letrado é o indivíduo que participa de forma significativa de eventos de letramento e não aquele que faz um uso formal da escrita" (MARCUSCHI:2008, p.25). Sendo assim, para fazer uso social da conversação digital, o indivíduo necessita, além do letramento convencional, ter conhecimento do sistema de escrita, o que implica que esta modalidade de conversação só serve aos alfabetizados.

Quanto à modalidade de uso da língua, distinguimos fala e escrita, respectivamente. A fala, do ponto de vista do plano da oralidade, é, ainda segundo Marcuschi (op.cit), uma forma de produção textual-discursiva para fins comunicativos na modalidade oral, de maneira natural, sem necessidade de outro aparato além do que está disponível no próprio ser humano.

\footnotetext{
Caracteriza-se pelo uso da língua na sua forma de sons sistematicamente articulados e significativos, bem com os aspectos prosódicos, envolvendo, ainda, uma série de recursos expressivos de outra ordem, tal como a gestualidade, os movimentos do corpo e a mímica (MARCUSCHI:2008, p.25).
}

A escrita caracteriza-se por ser um modo de produção também textual-discursiva para fins comunicativos, porém, com certas especificidades e se caracteriza por sua constituição gráfica, material, concreta, envolvendo recursos de ordem pictórica e outros (está no plano dos letramentos). É, segundo Marcuschi (op.cit.), uma modalidade de uso complementar à fala. 
As diferenças entre fala e escrita, no sentido aqui apresentado, contemplam os modos de representarmos a língua em sua condição de código. Os aspectos sonoros e gráficos representam, segundo Marcuschi (op.cit.), a diferença essencial entre uma e outra modalidade. Assim, a fala representa, segundo o autor, todas as manifestações textuais discursivas da modalidade oral, bem como a escrita representa todas as manifestações textuais discursivas da escrita.

Essa diferenciação, porém, não é o suficiente quando tentamos situar a conversação digital em um desses planos, pois, como viemos discutindo, o texto escrito aproxima-se sobremaneira da modalidade falada da língua. É necessário aprofundarmos, então, a discussão, de maneira que possamos estabelecer um ponto de contato mais profícuo entre as duas manifestações de língua.

Por tradição, os estudos relacionados às modalidades de fala e escrita têm tomado uma perspectiva dicotômica estrita, rigorosa, em que são divididas em blocos estanques, distintos, em que cada modalidade tem propriedades rigidamente controladas pela norma linguística considerada padrão. Marcuschi (2008), a fim de exemplificar essa dicotomia estrita, expõe o seguinte quadro:

\begin{tabular}{|c|c|c|}
\hline FALA & \multirow{9}{*}{ VERSUS } & ESCRITA \\
\hline CONTEXTUALIZADA & & DESCONTEXTUALIZADA \\
\hline DEPENDENTE & & AUTÔNOMA \\
\hline IMPLÍCITA & & EXPLÍCITA \\
\hline REDUNDANTE & & CONDENSADA \\
\hline NÃO-PLANEJADA & & PLANEJADA \\
\hline IMPRECISA & & PRECISA \\
\hline NÃO-NORMATIZADA & & NORMATIZADA \\
\hline FRAGMENTÁRIA & & COMPLETA \\
\hline
\end{tabular}

Estas dicotomias não representam, de maneira alguma, as características dos textos produzidos em situações sociais diversas, tampouco os usos discursivos que são feitos, uma vez que se baseiam na observação das condições empíricas de uso da língua, envolvendo planejamento e verbalização. Como representantes dessa visão estrita das dicotomias, Marcuschi cita Bernstein (1971), o próprio Labov (1972) e Ochs (1979).

Segundo o linguista, esta visão deu origem aos modelos prescritivos das gramáticas normativas, sugerindo visões estanques do uso da língua. Essa visão tem a tendência, 
naturalmente exposta, de considerar a fala como lugar do erro e do caos linguístico, tomando a escrita como lugar da norma e do bom uso da língua, não prestando, portanto, qualquer auxílio para a compreensão de que necessitamos para a análise da conversação digital.

Outra tendência para a distinção entre estas duas modalidades de língua está centrada em como cada uma delas afeta a sociedade e a produção de conhecimento: tratase da tendência fenomenológica de caráter culturalista. Marcuschi (2008) denomina essa tendência de visão culturalista e explica que esta não atende ao que se espera para uma análise linguística, uma vez que analisa os fenômenos globalmente, numa perspectiva macro, e entende que a adoção da escrita por uma determinada sociedade representa um avanço na capacidade cognitiva dos indivíduos.

Apesar de interessante, essa visão coloca a escrita em um patamar de tecnologia superior à fala, sem que se baseie em análises linguísticas, mas em fatos puramente culturais, como a criação de novas formas de expressão, o surgimento de novas formas literárias, a institucionalização do ensino de língua, entre as características mais evidentes. Marcuschi, citando Gnerre (1985), explica que essa corrente apresenta basicamente três problemas: etnocentrismo, supervalorização da escrita e tratamento globalizante.

O etnocentrismo está em ver outras culturas a partir da sua própria, valorizando positivamente aspectos desta última, o que cientificamente coloca esta perspectiva em questionamento. Há, também, uma supervalorização da escrita alfabética, colocando-a em posição de supremacia em relação a outras formas de manifestação sociocultural. O terceiro problema, apontado pelos autores, é justamente a generalização ou globalização das afirmações em torno do que seriam as sociedades letradas, uma vez que, mesmo dentro de sociedades com domínio da escrita, há uma diversidade de manifestações de letramento e escrita. É o caso do Brasil, em que há grupos com conhecimento da escrita formal e grupos que não têm acesso a essa modalidade da língua.

A perspectiva variacionista trata fala e escrita num mesmo patamar, considerando ambas em termos de processos educacionais, fazendo suas considerações de acordo com a variação entre padrão $x$ não padrão, focalizando as variações de uso da língua do ponto de vista dos dialetos e socioletos. Marcuschi apresenta o seguinte quadro para exemplificar essa tendência: 


\begin{tabular}{|l|l|}
\hline FALA E ESCRITA APRESENTAM & \\
\hline & \\
\hline LíNGUA PADRÃO & VARIEDADES NÃO PADRÃO \\
\hline LÍNGUA CULTA & LíNGUA COLOQUIAL \\
\hline NORMA PADRÃO & NORMAS NÃO PADRÃO \\
\hline
\end{tabular}

Tabela 3. A perspectiva variacionista. Adaptado de Marcuschi(2008, p.31)

Marcuschi ressalta que essa perspectiva não faz uma distinção entre fala e escrita, mas observa as variedades distintas, já que todas as variedades submetem-se a um tipo de norma. Uma dessas variedades será tida como padrão, uma vez que não são todas que o podem ser, simultaneamente. Os pesquisadores pertencentes a essa visão consideram escrita e fala como duas variedades linguísticas; o aluno, ao aprender a escrita na escola, torna-se, então, bidialetal. Nsse aspecto, Marcuschi posiciona-se da seguinte forma:

Minha posição é a de que fala e escrita não são propriamente dois dialetos, mas sim duas modalidades de uso da língua, de maneira que o aluno, ao dominar a escrita, se torna bimodal, fluente em dois modos de uso e não simplesmente em dois dialetos. (MARCUSCHI:2008, p.32)

Marcuschi apresenta uma quarta e última perspectiva, a visão sociointeracionista. Aqui a fala e a escrita são tratadas dentro de uma visão dialógica, na qual as características de uma e outra modalidade são tratadas de forma contínua, dinâmica. Marcuschi, citando Street (1995:162) entende que "essa tendência em direção à análise (crítica) do discurso unida à investigação etnográfica poderia ser uma das melhores saídas para a observação do letramento e da oralidade como práticas sociais".

O quadro seguinte oferece as principais características da perspectiva sociointeracionista:

\begin{tabular}{|l|}
\hline FALA E ESCRITA APRESENTAM \\
\hline DIALOGICIDADE \\
\hline USOS ESTRATÉGICOS \\
\hline FUNÇÕES INTERACIONAIS \\
\hline ENVOLVIMENTO \\
\hline NEGOCIAÇÃO \\
\hline SITUACIONALIDADE \\
\hline COERÊNCIA \\
\hline DINAMICIDADE \\
\hline
\end{tabular}

Tabela 4. Perspectiva sociointeracionista. Adaptado de Marcuschi (2008, p.33). 
Esta perspectiva teria apenas o inconveniente de ter "um baixo potencial explicativo e descritivo dos fenômenos sintáticos e fonológicos da língua, bem como das estratégias de produção e compreensão textual" (op cit. p.33). E prossegue fornecendo o caminho para resolver essa questão:

\begin{abstract}
...a proposta geral, se concebida na fusão com a visão variacionista e com os postulados da Análise da Conversação etnográfica aliados à Linguística do Texto, poderia dar resultados mais seguros e com maior adequação empírica e teórica. Talvez seja esse o caminho mais sensato no tratamento das correlações entre formas linguísticas (dimensão linguística), contextualidade (dimensão funcional), interação (dimensão interpessoal) e cognição no tratamento das semelhanças e diferenças entre fala e escrita nas atividades de formulação textual-interativa (MARCUSCHI:2008, p.33)
\end{abstract}

Aqui verificamos que essa perspectiva cabe bem aos propósitos apresentados neste trabalho: verificar as estratégias utilizadas pelos interlocutores em situação de conversa no contexto digital. Diante desta forma de apreciar o fato em análise, podem ser elaboradas análises voltadas para uma linha discursiva e interpretativa dos fenômenos linguísticos.

A vantagem de conceber as eventuais diferenças entre fala e escrita nesta perspectiva estaria no fato de que ideologias e visões preconceituosas em relação a esta ou àquela modalidade estariam neutralizadas, pois este modelo percebe a língua como um fenômeno ricamente interativo, dinâmico, voltado para a dialogicidade, para a interação verbal.

A conversação face a face assume a função de um tipo particular entre as interações verbais. Segundo Orecchioni (2006), "na interação face a face, o discurso é inteiramente 'coproduzido', é o produto de um trabalho colaborativo incessante" (p.11).

Entre as condições essenciais para que a conversação ocorra, podemos citar: o envolvimento numa interação centrada, a execução numa identidade temporal, a participação de pelo menos dois interactantes e ao menos uma troca de turno. Devemos ressaltar, porém, com base em Marcuschi (2005, p.15), que "a interação face a face não é condição necessária para que haja uma conversação, como no caso das conversações telefônicas". 
Diante de todos esses aspectos, podemos colocar a interação verbal via MSN como uma conversação, pois:

a) ocorrem em tempo real/sincrônico $\rightarrow$ Assim como no caso das conversações telefônicas, as conversações digitais ocorrem em sincronia, a despeito dos problemas técnicos que ocasionalmente possam ocorrem: queda de conexão, falha do software, etc.

b) há a participação de ao menos dois interlocutores $\rightarrow$ O software MSN em suas versões mais recentes possibilita a interação de vários participantes na conversação, mas, na maioria das vezes, é utilizado por apenas dois usuários.

c) há troca / alternância de turno $\rightarrow$ Postulamos aqui uma nova interpretação para a questão do turno, conforme veremos adiante, substituindo-o pelo conceito de Ato Enunciativo Digital. Nesse sentido, há troca de atos dessa natureza entre os interlocutores.

d) o envolvimento se dá numa interação centrada $\rightarrow$ Geralmente, os interlocutores estão voltados para a interação, interagindo regularmente durante as trocas. Eventualmente, porém, devido às especificidades do meio, pode-se realizar outras tarefas enquanto se "conversa" por meio do MSN (pesquisar na Internet, ler notícias, conversar com outros interlocutores, etc)

Segundo Orecchioni (2006, p.15), “o objetivo da análise conversacional é, precisamente, explicitar essas regras que sustentam o funcionamento das trocas comunicativas de todos os gêneros..."

Convém lembrar, que, apesar de se tratar de uma conversação, o suporte usado para a interação verbal é a escrita. Assim como Hilgert (2000, p.17), não colocaremos escrita e fala numa perspectiva dicotômica, pois tomaremos o texto "falado por escrito" como o resultado de um uso, mediante um tipo específico de prática social de produção textual.

Concordamos com a posição do autor quando diz que a comunicação na internet “...se afina muito mais com o texto falado prototípico (conversação espontânea, conversação telefônica) do que com o correspondente escrito."

Diante das limitações da escrita, porém, nela não se manifestam algumas características próprias da interação face a face, difíceis ou impossíveis de serem representadas pela escrita, tais como gestos e expressões faciais. 
Ainda assim, é importante salientar que, muitas vezes, o usuário/interlocutor dispõe de recursos gráficos (símbolos e emoticons) que tendem a suprir essa carência da expressividade física (olhar, gestos, etc), conforme veremos mais adiante.

Nas conversações digitais, os interlocutores utilizam o canal eletrônico cientes de que terão sua interação mediada pela escrita. Essa modalidade comunicativa irá requerer do interactante uma forma de escrita da língua mais flexível e informal do que aquela que, em tese, se esperaria da escrita.

É evidente que a forma prototípica da escrita prevê, segundo Chafe (1985), um processo lento, planejado e revisado, diferente do que ocorre com a fala, que é localmente produzida, sendo, portanto, fragmentada, ainda que ambas sejam dotadas de sentido e significados. Chafe entende que essa dicotomia se dá pelo fato de que a escrita é um processo solitário, de formulação e reformulação, enquanto a fala se configura de maneira dinâmica e local.

Nesse aspecto, a Conversação Digital oferece um desafio à dicotomia proposta por Chafe, uma vez que esta se vale da escrita, ou seja, da linguagem digitada pelos interactantes, que aparece na tela em tempo real, numa forma de interação que se assemelha mais à conversação face a face do que à escrita, por meio dos turnos - ainda que de maneira diferenciada do modelo prototípico.

Marcuschi (2008) faz uma releitura dessa dicotomia, e afirma que a análise linguística se volta para o código, especificamente. Essa perspectiva, em sua forma mais rigorosa, deu origem ao prescritivismo como uma norma única e imutável, a chamada norma culta. "É dela que conhecemos as dicotomias que dividem a língua falada e a língua escrita em dois blocos distintos, atribuindo-lhes propriedades típicas" (p.27)

O linguista afirma que, seja na modalidade escrita ou falada, a língua reflete, em grande parte a organização da sociedade. Esse fato se dá porque a língua é uma instituição social, e depende da própria sociedade para existir e funcionar. Sendo assim, é a forma pela qual os homens criam suas representações do mundo e produzem sentido mutuamente.

A escrita não constitui um simples espelhamento da fala, mas uma relação muito intimista das práticas sociais com os usos que se fazem nas mais diversas modalidades da língua dentro destas práticas. 
Diante do exposto, assim como a fala não tem características intrinsecamente negativas, mas pragmáticas, também a escrita não teria, da mesma maneira, uma supremacia privilegiada ou superioridade em relação às práticas linguísticas. Aliás, conforme Stubbs (1980), a fala existe há muito mais tempo que a escrita, sendo esta última uma invenção recente na história da humanidade. A escrita só adquiriu prestígio social por uma questão ideológica, e esse prestígio não é proveniente de algum critério intrínseco linguístico.

Marcuschi (op.cit) propõe o quadro seguinte para definir o que considera um continuum tipológico das práticas sociais de produção textual:

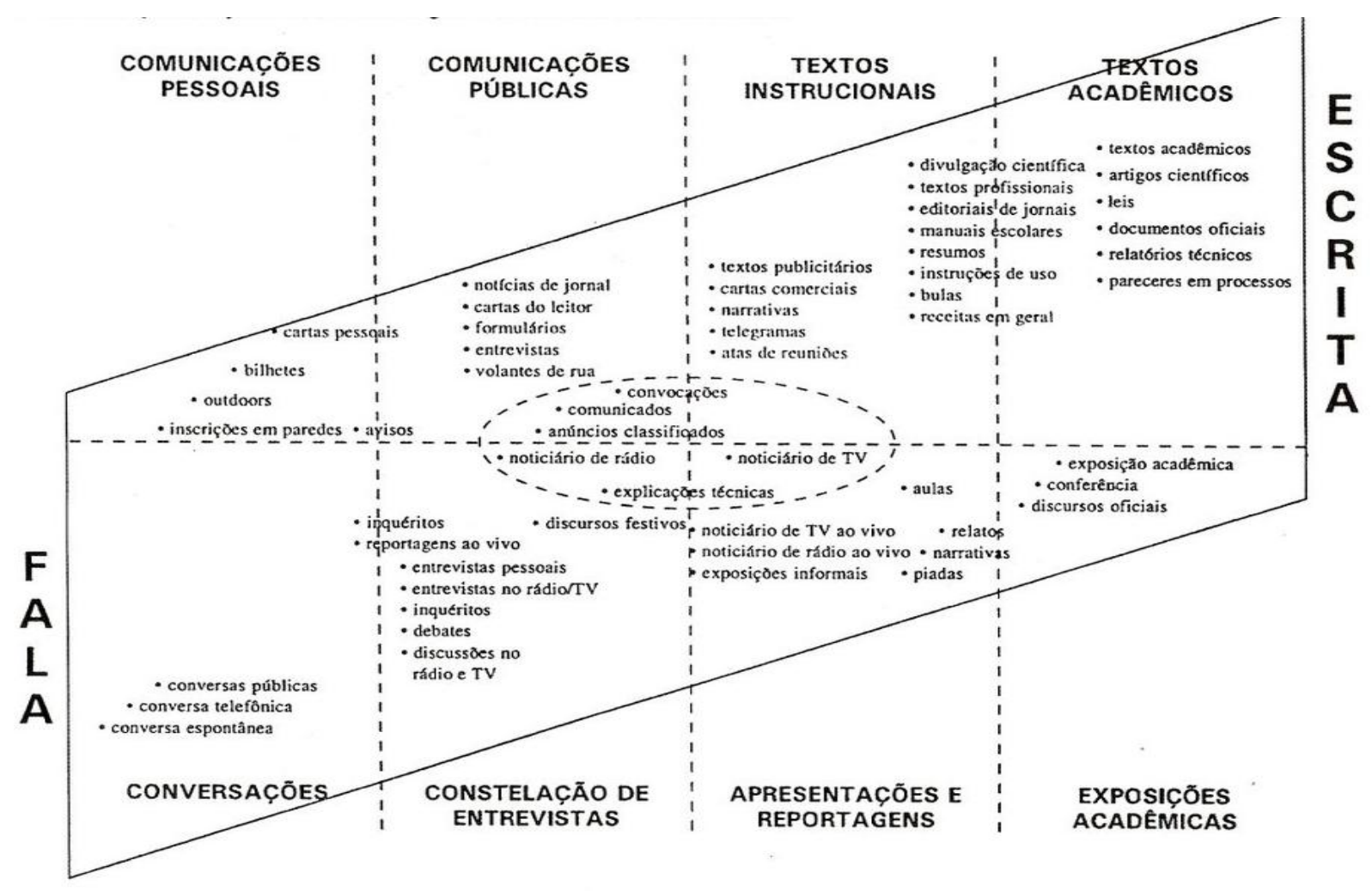

Figura 1. Representação do continuum dos gêneros textuais na fala e na escrita (MARCUSCHI:2008)

A partir desse quadro, observamos que a conversação digital via comunicador instantâneo, como MSN ou SKYPE, estão mais próximas de um texto falado, da conversação face a face, ou espontânea, do que para o texto escrito, que tende a ser regido por normas e convenções mais delimitadas. 
A fala e a escrita se dão, portanto, num continuum tipológico: embora cada uma tenha suas características próprias, não existem diferenças de ordem essencial entre elas, nem, muito menos, grandes arbitrariedades e oposições. Pensar que existe uma superioridade de qualquer uma das duas modalidades é um modo equivocado de conceber o fenômeno, embora exista a crença de que a escrita tenha mais prestígio social do que a fala, mas isso decorre simplesmente de uma postura ideológica.

As duas modalidades servem para que a interação verbal tenha sucesso, em diferentes contextos e gêneros textuais, na diversidade dialetal e/ou de registro. São, resumidamente, duas modalidades pertencentes ao mesmo sistema linguístico, existindo apenas diferenças de ordem estrutural, pois se distinguem nos seus modos de aquisição, nas suas condições de produção, transmissão, recepção e uso, e nos meios pelos quais os elementos de estrutura são organizados.

Ainda de acordo com Marcuschi, a fala é de concepção oral e meio sonoro, ao passo que a escrita é de concepção escrita e meio gráfico. O esquema abaixo oferece uma representação das possibilidades de usos e práticas sociais por meio do meio de produção (sonoro versus gráfico) e da concepção discursiva (oral versus escrita):

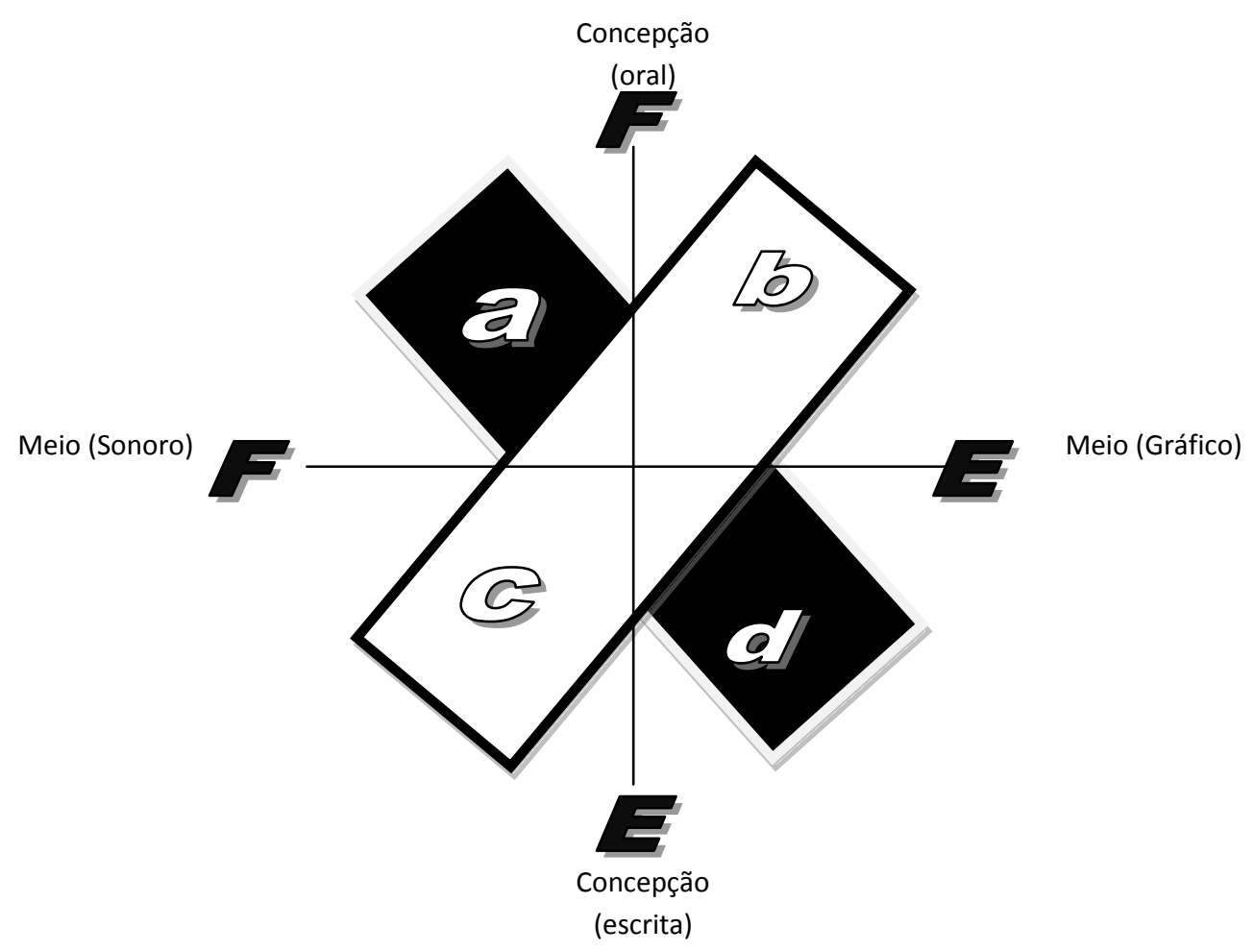

Figura 2. Representação da oralidade e escrita pelo meio de produção e concepção discursiva. (MARCUSCHI:2008) 
Assim, a partir da proposta de Marcuschi, o gênero Conversação Digital se encontra no domínio b, ou seja, possui uma concepção oral, porém, no meio gráfico. Teríamos, assim, a seguinte configuração quanto ao meio de produção e concepção discursiva:

\begin{tabular}{|c|c|c|c|c|c|}
\hline GÊNERO & \multicolumn{2}{|c|}{ MEIO DE PRODUÇÃo } & \multicolumn{2}{c|}{ CONCEPÇÃo DISCURSIVA } & DOMÍNIO \\
\hline $\begin{array}{c}\text { CONVERSAÇÃO } \\
\text { DIGITAL }\end{array}$ & SONORO & GRÁFICO & ORAL & ESCRITA & \\
\hline
\end{tabular}

Tabela 5: Distribuição do gênero Conversação Digital de acordo com o meio de produção e a concepção discursiva.

Sendo assim, se considerarmos a conversação digital como um gênero textual, entenderemos que este perpassa a oralidade no que diz respeito à concepção, ou seja, a pessoa que está à frente do computador conversando com um interlocutor "sente-se" realmente dialogando, e usa os recursos que considerar mais próximo da naturalidade do falar para expressar seus pensamentos. Para isso, a pessoa utiliza um meio de produção não sonoro, ou gráfico, levando o "falante" a transmutar na tela do seu computador uma "fala" que se aproxima, ao máximo, de suas marcas linguísticas com apoio na oralidade.

\subsection{Comunicadores Instantâneos}

O MSN Messenger (Microsoft Service Network) é um programa online de mensagens instantâneas, podendo ter uma lista de amigos "virtuais". Pode-se dizer que é um ambiente reservado, restrito, mais "familiar", mais responsável, e pode-se acompanhar quando os "interlocutores" entram e saem da rede. O programa permite que um usuário da Internet se comunique com outro que tenha o mesmo programa em tempo real.

Originou-se do ICQ, em 1997, que servia como interação online antes do MSN, embora ainda seja muito utilizado em outros países. O sucesso do MSN pode ser explicado por ser integrado ao serviço de e-mail Hotmail, por ser incluso no Windows XP e por ter uma intensa publicidade junto ao público jovem.

Também tem como concorrente o Yahoo! Messenger, outro serviço igualmente integrado a e-mail. A interação por esse ambiente aproxima-se muito dos outros chats abertos, pois utiliza os mesmos mecanismos para a comunicação e o léxico (texto) é determinado pelo internauta. 


\section{a) Características Técnicas}

Os Comunicadores instantâneos são aplicações que permitem o envio e recebimento de mensagens de texto em tempo real. Por meio desses programas, o usuário é informado quando algum de seus amigos, cadastrado em sua lista de contatos, está conectado à rede. A partir daí, eles podem manter conversações por meio de mensagens de texto - ou até de som e imagem.

Normalmente, esses programas incorporam diversos outros recursos, como envio de figuras ou imagens animadas, conversação em áudio - utilizando as caixas de som e microfone do sistema, além de vídeo conferência. Inicialmente, possibilitavam a conversação entre dois interlocutores apenas, mas hoje suporta diversos interlocutores ao mesmo tempo.

O primeiro programa deste tipo largamente utilizado em escala global foi o ICQ, que inovou e revolucionou o conceito de mensagens online. O MSN Messenger (atualmente numa versão chamada Windows Live Messenger) é um desses comunicadores. Podemos dizer que é um dos preferidos pelos brasileiros, pois, é um dos programas mais baixados em sites populares de downloads no Brasil, como o www.baixaki.com.br.

Neste trabalho, utilizamos os recursos do MSN em sua última versão, o Windows Live Messenger, que pode ter sua aparência visualizada abaixo:

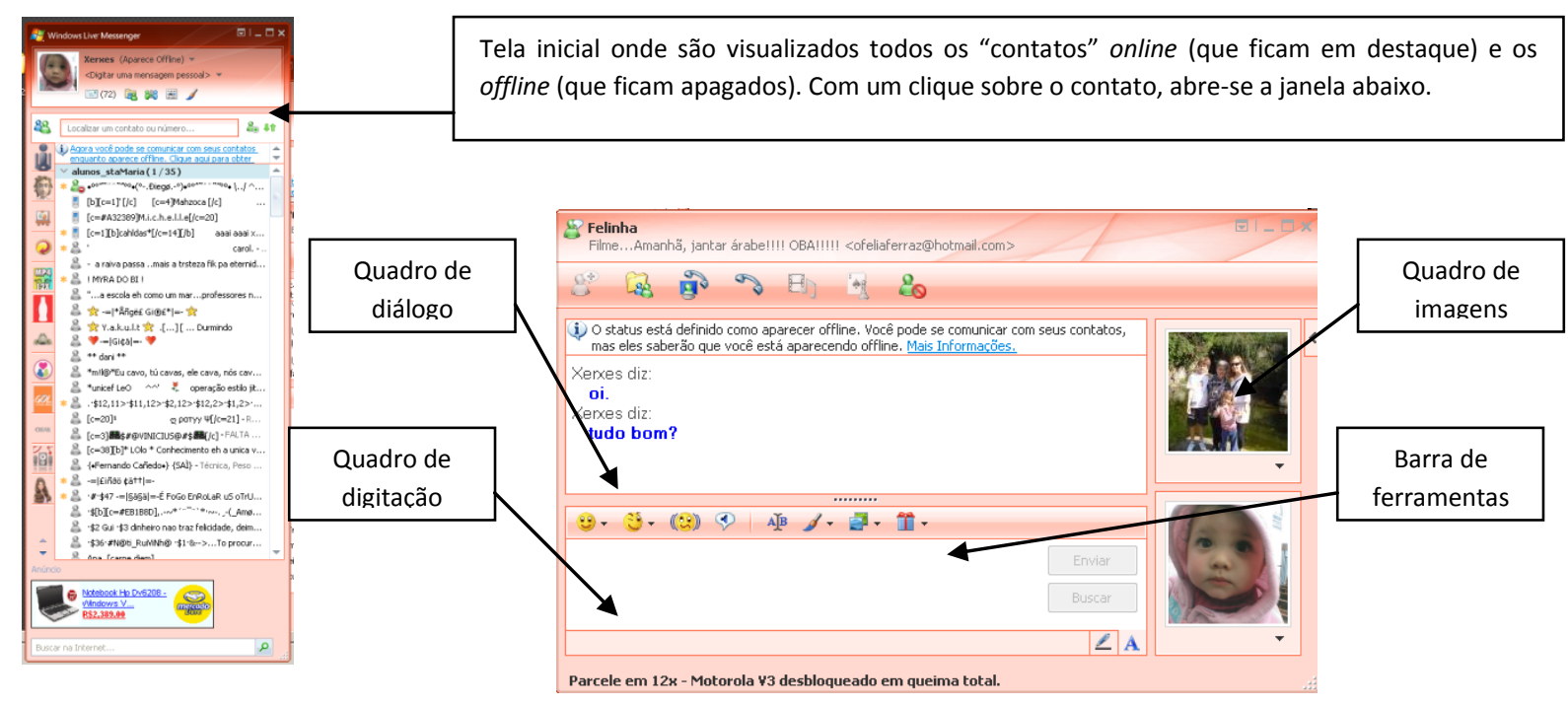

Figura 3. Demonstração das funções do Microsoft Messenger 
b) A interação síncrona / em tempo real e a interatividade.

Podemos entender a interação de duas formas possíveis:

a) Do ponto de vista da informática

b) Do ponto de vista das relações humanas.

Se pensarmos em termos de informática, a interação pode ser entendida como as formas de mediação homem-máquina. Em outras palavras, de que forma ou maneiras a máquina troca informações com o homem. A qualidade e a rapidez com que essas trocas ocorrem, bem como a facilidade de acesso do homem ao sistema (interface) levam ao conceito de interatividade. Há interatividade quando o homem se vale dos recursos técnicos do computador para realizar tarefas as mais variadas: desde digitar um texto até o acesso à Internet.

Do ponto de vista das relações humanas, é correto afirmar que pessoas são ligadas umas às outras por meio de um sistema intrincado de relações sociais e a interação assume lugar importante nesse processo, uma vez que funciona como uma liga ou um elo entre as formas de contato possíveis. Não existe ação humana que possa ser dissociada da interação: o ser humano, por excelência, age e interfere sobre a realidade a partir das impressões e da visão que possui do mundo e das coisas que nele estão; o significado destas coisas é resultado direto da interação social, do contato. Esses significados são trabalhados e transformados por meio da interpretação que cada um tem sobre um fato social em ação, em interação.

No contexto da interação homem-homem com mediação do computador, essas duas formas de enxergar a interação se fundem em uma só, conforme ilustrado abaixo:

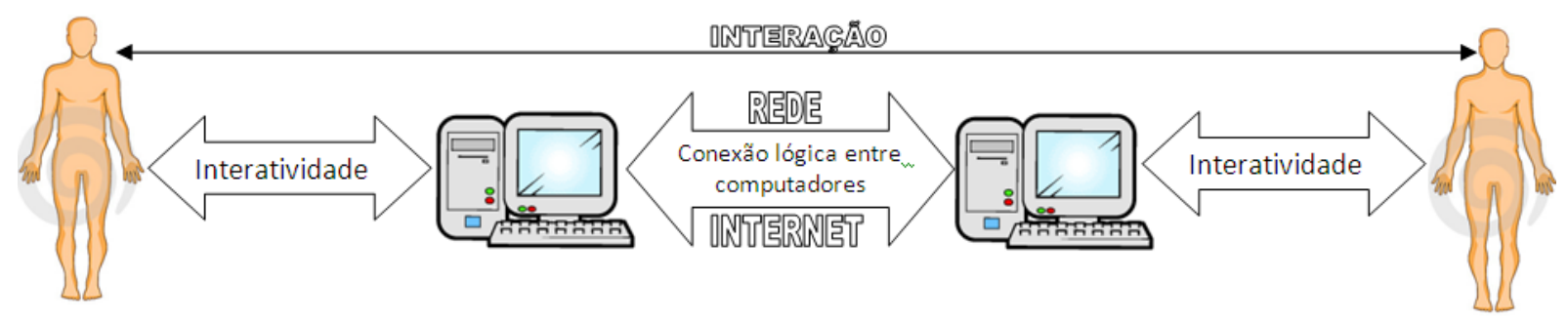

Figura 4. Relação homem - homem com mediação de computadores 
Assim sendo, por meio da interatividade admissível entre o homem e a máquina, é possível estabelecer conexão lógica por meio da rede Internet com outras máquinas e interagir com outro interlocutor. Tudo isso está disponível, hoje, em tempo real.

A interação tem um papel fundamental no que concerne à comunicação mediada por computador na internet. A internet, por meio da invasão no cotidiano global, impulsionou a formação de novos estilos de linguagem, por meio de sistemas abertos de comunicação em tempo real, como os chats, por exemplo, e programas específicos, como o MSN e SKYPE.

Os usuários desses sistemas vão desde crianças em fase escolar até adultos, em suas relações sociais ou profissionais. Essa experiência tem aberto debates em torno das influências que o texto escrito vem sofrendo, assim como as consequências no processo de aprendizagem nesses internautas que fazem uso do sistema, por estarem experimentando novas relações entre o campo oral e escrito no gênero discursivo.

\section{c) A linguagem e a interação no MSN}

A conversação digital é uma modalidade de interação verbal por escrito em tempo real, com uma diferença crucial em relação aos chamados chats ou bate-papos: no chat aberto, geralmente não se conhecem os interlocutores, e os tópicos conversacionais são mais abertos, afeitos à descontinuidade, devido ao número, em geral, excessivo de participantes.

Nos chats abertos, o foco temático parece variar muito, e uma pessoa tende a conversar com mais de um interlocutor, não havendo uma progressão temática e os assuntos se misturam até o total esquecimento dos eixos condutores da sala.

Não se pode considerar a conversação digital um chat prototípico, mas talvez uma modalidade mais apurada e refinada deste: na prática do chat aberto, este apresenta uma descontinuidade, saltando de temas em temas, sem uma centração que seria necessária à modalidade dual de conversação. Pessoas vão aos chats para se sociabilizarem, para entrarem em comunicação com pessoas e países distantes. Algumas procuram amizade, outras amor, aventuras, etc., e as mais variadas razões, até mesmo nenhuma: entram pelo simples prazer de "teclar". 
No MSN, por sua vez, a conversação é centrada: há mudanças e alternâncias de tópicos, mas estas são mais próprias da conversação face a face. No MSN, os interlocutores não podem demorar para responder aos atos enunciativos de chamada, pois ambos requerem que suas intervenções sejam prontamente respondidas ou atendidas. $O$ andamento da conversação, como esta se dá em tempo real; é ininterrupto. O resultado dessa interação síncrona está na economia das formas linguísticas escritas, fator importante para manter o ritmo do processo.

Jonsson (1997) afirma que, na comunicação sincrônica, os estilos são bastantes informais. Segundo o autor, é comum, nas mensagens trocadas durante o processo de comunicação digital síncrona, encontrarmos atos de fala ao estilo da interação face a face. 0 início de uma conversação digital se dá, geralmente, por meio de atos de fala de cumprimento entre os agentes, assim como a finalização da interação é sempre precedida pelas fórmulas prototípicas de despedida.

Sendo assim, Jonsson afirma que, ao se aproximar dos eventos de fala, os usuários das conversações síncronas na internet desenvolvem meios ou dispositivos que acabam por economizar no uso da forma escrita, aumentando a velocidade de comunicação.

Dentre os meios ou recursos mais comuns, estão as reduções de palavras, tendo em vista preservar aspectos fonéticos, sempre ligados à oralidade, tais como "bjs" (Beijos) ou "kd vc" (cadê você). Entre os exemplos oferecidos por Jonsson, estão as expressões inglesas "wassap" (What's up?). Letras também são muito utilizadas nessa redução, tal como em "how $r$ u" (How are you?). Há também a utilização de letras e números para representar expressões e palavras cuja interpretação só é possível levando-se em consideração efeitos fonéticos gerados por meio da leitura dos símbolos, tais como "CU" (See you) ou "U2" (you too).

Ainda, seguindo esse "padrão" de economia da escrita em detrimento da velocidade comunicativa, é comum a substituição de palavras ou expressões por abreviações, tais como BTW ("by the way"), M/F ("male or female?") e BRB ("be right back").

Jonsson (1997) entende que o uso destes recursos implica não somente uma simplificação das formas de escrita, mas também a diminuição do tempo de decodificação 
na leitura, fazendo com que os usuários familiarizados aproximem-se ainda mais da velocidade da fala.

O autor entende que, no processo de comunicação em tempo real, as opções textuais dos interlocutores, no que tange aos níveis semânticos e sintáticos, determinam o processo de intercompreensão interativa. Não há, no meio digital, alguns recursos próprios da interação face a face prototípica, os elementos paralinguísticos que complementam os sentidos da conversação. Há, portanto, vários meios para compensar esta falta.

Há os emoticons, abreviações que representam ações e linguagem corporal. O autor exemplifica com "lol" (laughing out loud) e "rotfl" (rolling on the floor laughing). Vocalizações transcritas como "hehehe" ou "argh". Letras maiúsculas e sinais de pontuação também podem ser utilizados para suprir os elementos paralinguísticos, tal como nos mostra o exemplo abaixo:

\section{Exemplo 1:}

Fiona :

FALA Aíl|IIIIIIIIIIIIIIIIIIIIIIIIIIII!!

Mindim:

Fala o que q????

Fiona:

Rsrsrsrsrsrsrsrsrsrsrsrsr

Pode-se perceber, inclusive, que diversas vezes essas repetições e abreviaturas ou sinais gráficos constituem um "turno" inteiro. As ocorrências de repetições de sinais de pontuação e de caixa alta como simbolizadores de alterações entonacionais e prosódicas são também frequentes na interação no chat. 


\section{CAPÍTULO II \\ Organização e Estrutura da Conversação do tipo \\ face a face}

\subsection{A organização conversacional face a face}

A conversação é uma atividade própria do ser humano. Marcuschi (2004) diz que ela é a primeira das formas de linguagem a que estamos expostos e a única da qual nunca podemos abdicar durante a vida. É o gênero básico da conversação humana.

Uma das características mais marcantes da conversação face a face, ou seja, os dois interlocutores devem estar engajados em uma interação centrada e focados em suas trocas imediatas.

Orecchioni (2006, p.08) afirma que a vocação comunicativa da linguagem verbal nos remete a algumas características inerentes a ela:

- Alocução: um destinatário fisicamente distinto do falante.

- Interlocução: troca de palavras com intencionalidade, em que se alternam os papéis do emissor de do receptor.

- Interação: troca comunicativa entre os interactantes, criando redes de influências mútuas.

O ser humano é, por excelência, um ser comunicativo e comunicador, sedento de se fazer ouvir, de ser ouvido, e é naturalmente orientado a interagir com os seus iguais. Essa interação, geralmente, se dá por meio da conversação, onde pode falar e ser ouvido, como também ouvir e interferir na fala do outro.

Para que se possa considerar a atividade verbal como conversação, é necessário que haja pelo menos dois interlocutores e uma troca de turno, ou, seja, que estes participantes estejam voltados cognitivamente e visualmente para essa tarefa. Esses fatores revelam o caráter dialógico da linguagem, que se estabelece em função do outro a partir de perguntas 
e respostas, asserções e réplicas, entre outras estratégias que permitem uma interação mútua entre os participantes.

Durante essa interação, fatores sociais relevantes são acionados para que a negociação conversacional não se rompa, e os tópicos vão sendo apresentados sujeitos, sempre, ao princípio geral da cooperação.

É importante ressaltar que não é necessário estar fisicamente "face a face" para que as ações coordenadas ocorram, mas é necessário que elas devem co-ocorrer num eixo temporal simultâneo, e devem, também, compartilhar alguns conhecimentos sociais comuns, sejam os gestos, olhares, sorrisos e movimentos.

A conversação prototípica é uma interação do tipo simétrica, igualitária, cujo único objetivo explícito é o prazer de conversar, tendo os participantes os mesmos direitos e deveres pragmáticos. Segundo Koch(1998), a conversação organiza-se em intervenções feitas pelos interlocutores por meio das interações de fala, tecendo considerações sobre assuntos diversos do dia-a-dia, podendo se estender até os mais complexos (áreas científicas, política, economia), por meio de turnos elaborados em interações do tipo simétricas ou assimétricas.

Durante o evento conversacional, os interlocutores trocam enunciados que determinam o grau de simetria entre eles, e orientam, inclusive, quanto à alternância dos papéis de falante e ouvinte e tomada de turno.

Chamamos de simétricas as interações em que há equilíbrio existente entre os turnos trocados no evento conversacional, como é o caso dos diálogos espontâneos. Assimétricas são aquelas em que interlocutores não conquistam os mesmos direitos ou não interferem de maneira equilibrada no evento comunicativo, deixando que um dos envolvidos tenha o poder do turno, como no caso das aulas expositivas e palestras acadêmicas.

Marcuschi (2001) salienta que, além da organicidade da conversação, temos as convenções sociais, normas culturais e imagens mútuas que as pessoas constroem uma das outras, e esses aspectos interferem diretamente nos processos inferenciais e construções de informações.

O contexto adquire também um papel fundamental em meio à construção de sentidos no ato conversacional. Esse contexto, ou ambiente extralinguístico, envolve uma 
situação imediata, o momento e as condições pragmáticas em que o evento acontece, e envolve, inclusive, características dos próprios participantes, suas convicções e papéis sociais.

Dentro do contexto, ou situação comunicativa, devem ser considerados o lugar (quadro espacial e temporal, o objetivo, os participantes), o quadro participativo (papéis interlocutivos, tipos de receptores, tropo comunicacional, papéis interacionais) e balanço (papel do contexto, relações entre contexto e texto conversacional). O quadro espacial está focado nos aspectos físicos do lugar onde ocorre a conversação.

É importante observar que a Conversação é considerada, a partir da ótica da Análise da Conversação, como uma atividade linguística estruturalmente organizada e sempre ocorre em um contexto ou circunstância em que os interactantes estejam engajados. (cf MARCUSCHI:2001, p.17)

A organização conversacional possui vários níveis passíveis de serem observados e analisados, e se manifestam de várias maneiras, como a tomada de turno, a organização tópica, repetições, correções, entre outros elementos constituintes da constelação do discurso conversacional, conforme veremos a seguir.

\subsection{Características da conversação face a face}

Segundo Rodrigues (1993, p.18), “a conversação é um evento de fala especial: corresponde a um interação verbal centrada, que se desenvolve durante o tempo em que dois ou mais interlocutores voltam sua atenção para uma tarefa comum, que é a de trocar ideias sobre determinado assunto". Assim sendo, a conversação é uma atividade eminentemente humana, em que os interlocutores se envolvem centrados num único objetivo: comunicar.

Essa atividade é culturalmente marcada, e há nela uma complexa rede de significados simbólicos, onde se alternam códigos meramente linguísticos, prosódicos, entonacionais, gestuais, entre outros.

Marcuschi(2005) considera que a conversação possui cinco características constitutivas: 
a) A interação entre pelo menos dois falantes.

b) Ocorrência de pelo menos uma troca de falantes.

c) Presença de uma sequência de ações coordenadas.

d) Execução numa identidade temporal.

e) Envolvimento numa "interação centrada".

Essas características permitem-nos compreender a conversação como um movimento de envolvimento mútuo, em que somente terá sucesso caso haja engajamento entre os interlocutores. Assim, para que um texto possa ser considerado conversacional, é necessário que haja ao menos uma troca de turno entre os participantes, em número mínimo de dois interlocutores. Dessa forma, excluímos os monólogos, sermões, conferências, entre outras, pois não constituem textos conversacionais.

É importante ressaltar que a interação face a face não é condição única para que haja a conversação. É o caso das conversações telefônicas, em que o canal permite com que os interlocutores conversem entre $\mathrm{si}$, mesmo distantes fisicamente. $\mathrm{O}$ que não pode faltar na conversação é a centração, ou seja, que a conversação centrada num assunto, o que nos permite dizer que todos os interlocutores estarão envolvidos no tópico da conversa; e também a identidade temporal, ou seja, em tempo síncrono.

\subsection{Turno Conversacional}

Segundo Galembeck (1993, p.55), "umas das características mais evidentes da conversação é, seguramente, o fato de que os interlocutores alternam-se nos papéis de falante e ouvinte". Partindo desse pressuposto, é imprescindível iniciar o estudo das conversações por meio da observação e análise da alternância desses papéis, verificando como os interlocutores constroem conjuntamente o diálogo no contexto conversacional.

O turno é a participação de cada um dos interlocutores no exercício da fala, no momento em que um interlocutor passa de ouvinte a falante. Em outras palavras, segundo Fávero, Andrade e Aquino (2007, p.35), "estruturalmente, o turno define-se como a produção de um falante enquanto ele está com a palavra...".

A ideia de turnos, segundo Galembeck (1993, p.60), está ligada à alternância dos membros de um grupo na consecução de um objetivo, mantendo o diálogo entre os 
falantes, para que a entrevista se concretize. Cada intervenção, do ouvinte, mesmo aquelas de monitoramento da conversa, do tipo "uhn uhn", "certo"; "perfeito" será considerada como turno. Isso implica dizer que o falante não apenas fala, mas também ouve. Esse revezamento de papéis falante/ouvinte é consecutiva e caracteriza uma série de turnos que podem ser simétricos ou assimétricos.

$\mathrm{Na}$ conversação simétrica, ambos os interlocutores contribuem efetivamente para o desenvolvimento do tópico conversacional, ou seja, se revezam constantemente nas posições de falante e ouvinte, e todos dão contribuições relevantes em relação ao tópico, engajando-se substantivamente na consecução do objetivo comum. Todos os interlocutores têm igual oportunidade de falar como nas conversas corriqueiras do dia-adia. Já no diálogo assimétrico, apenas um dos interlocutores desenvolve o assunto e "domina a cena" por meio de uma série de turnos nucleares, ao passo que o outro só contribui com intervenções episódicas, marginais em relação ao tópico do fragmento. Entrevistas e consultas, entre outras, constituem exemplos de interações assimétricas. (GALEMBECK:2009, p. 1940)

No trecho acima, o autor esclarece sobre as diferenças entre os tipos de conversação, que podem ser simétricas ou assimétricas, ou seja, se os falantes contribuem igualmente para o desenvolvimento do tópico conversacional (assunto) e para a iniciação de novos tópicos, ou se um dos interlocutores assume o comando da fala, desenvolvendo solitariamente o tópico enquanto o outro apenas acompanha o que está sendo falado.

É importante lembrar que Galembeck (1993) considera todas as intervenções dos interlocutores no ato comunicacional, separando aquelas com valor informativo ou referencial - que desenvolvem o assunto tratado, de outras sem valor referencial intervenções breves, sinais de que um dos interlocutores está seguindo as palavras de seu emissor (hun hun, certo, ok, etc).

Quanto à diferenciação entre os tipos de turnos possíveis, o autor considera que eles podem ser nucleares ou inseridos.

O turno nuclear é aquele que "possui um valor referencial nítido, ou seja, que veicula informações" (p.61). É o turno nuclear que efetivamente leva ao desenvolvimento do tópico conversacional. São aqueles que trazem novas informações à conversação. 
O turno inserido, por sua vez, "não tem um caráter referencial, ou seja, não desenvolve o tópico" (p.61). Sua finalidade é apenas apontar ao falante que o interlocutor que não está de posse do turno naquele momento "acompanha, monitora e vigia" as enunciações. Segue exemplo seguinte:
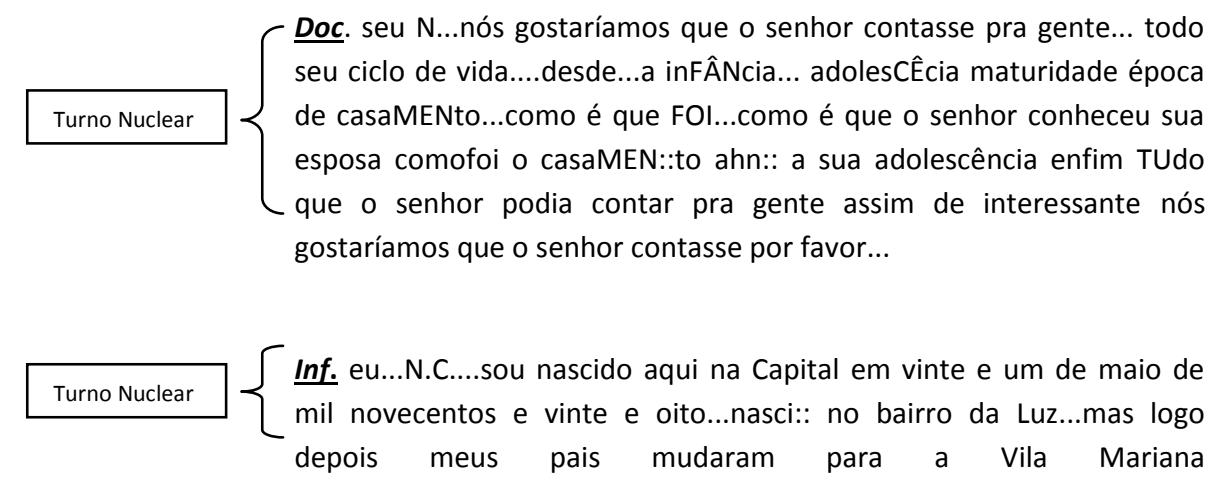

Turno Inserido $\{$ Doc. uhn uhn

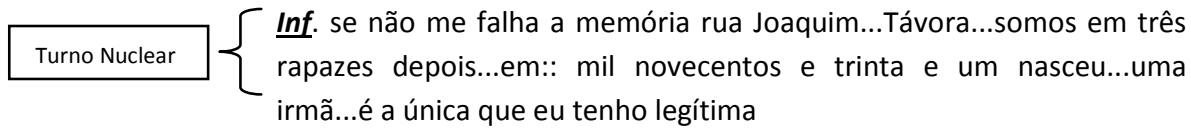

(PROJETO NURC/SP INQUÉRITO № 208 - BOBINA № 79 - INF. № 252)

O autor considera todas as intervenções dos interlocutores importantes para a organização do texto conversacional. Cada enunciação possui um significado importante para traçar a trama do diálogo.

Mesmo os turnos inseridos, considerados como um elemento de caráter referencial, possuem suas funções, que podem ser interacionais ou de contribuição acidental para o desenvolvimento do tópico. Os turnos inseridos com função interacional demonstram ao interlocutor que "o canal de comunicação está aberto e que, assim, o falante pode continuar a sua fala" (p. 68).

Quando o turno inserido contribui incidentalmente para o desenvolvimento do tópico, em geral, apresenta um resumo das palavras de seu interlocutor, mostrando ao mesmo tempo, que está acompanhando o assunto e dando pistas para a continuidade do tópico. 
O autor apresenta também as estratégias de gestão de turno, que são os procedimentos por meio dos quais se alternam os papéis conversacionais. Há duas formas de se alternarem os papéis conversacionais: a passagem de turno e o assalto ao turno.

No processo de "passagem de turno", há uma colaboração implícita ou explicitamente solicitada pelo interlocutor. A passagem é requerida quando o falante finaliza seu turno com perguntas como né?, não é?, entende?, buscando com esse procedimento uma confirmação por parte do ouvinte.

A passagem requerida é assinalada pelo falante por uma pergunta direta (...)ou pela presença de marcadores que testam a atenção ou buscam a confirmação do ouvinte com: né?, não é?, sabe?, entende? (...) Onde a interrogação é a solicitação mais explícita endereçada ao ouvinte que, por isso mesmo, intervém com um turno nuclear ou inserido. (GALEMBECK:2009, p.1941)

A passagem pode ser também consentida - que indica uma entrega implícita do turno. Neste último caso, mesmo que o interlocutor não peça para o ouvinte assumir o turno, ele faz indicações por meio de alguns recursos, como a pausa, para indicar que já concluiu o seu.

Essa modalidade [a passagem consentida] corresponde a uma entrega implícita, o ouvinte intervém e passa a deter o turno, sem que o concurso tenha sido diretamente solicitado. Nesse caso, o lugar relevante para a transição é assinalado pelo final de uma frase declarativa... (GALEMBECK:2009, p.1941)

Na estratégia de "assalto ao turno", a intervenção é feita pelo ouvinte, que passa a falante, invadindo a fala do interlocutor de posse do turno no momento. Há, também, duas formas de ocorrência do assalto ao turno: com deixa e sem deixa.

O assalto ao turno é marcado pelo fato de o ouvinte intervir sem que a sua participação tenha sido direta ou indiretamente solicitada. Em outras palavras, o ouvinte "invade" o turno do falante fora de um lugar relevante de transição, por isso o assalto apresenta uma violação do princípio básico da conversação, conforme o qual apenas um dos interlocutores deve falar por vez. (GALEMBECK:2009, p.1941) 
No assalto com deixa, o ouvinte, percebendo um momento de hesitação, pausa, ou mesmo alongamento do interlocutor, invade a fala e tenta tomar o turno para si.

No assalto sem deixa, a entrada é "brusca e inesperada", pois não houve hesitação do falante. Simplesmente há uma intervenção não solicitada em meio à enunciação de um dos interlocutores.

Galembeck também aponta alguns procedimentos de sustentação do turno, que se vale do preenchimento das "brechas" ocorridas durante os eventos de fala com marcadores como entende? não acha?, que servem apenas para buscar a aprovação do ouvinte, ou repetições de palavras ou sílabas, bem como recursos prosódicos (elevação da voz), para que o ouvinte entenda que o falante ainda não terminou o seu turno. Pretende-se, por meio desses recursos, que a posse do turno seja mantida.

O autor finaliza alertando que

...não falamos apenas para dar ou receber informações o tempo todo, e sim, também, para estabelecer algum tipo de relação com o outro, ainda que, repetindo coisas já ditas, procedendo a desvios temáticos. Tanto os turnos nucleares quanto os inseridos são de extremo valor para a Unidade Discursiva, pois do ponto de vista informativo o primeiro se torna mais relevante para informar, fazer compreender e o segundo é relevante do ponto de vista interacional, para alimentar a conversação, parafraseando, alterando o sentido e comentando. (GALEMBECK:2009, p.1943)

\subsection{0 tópico discursivo}

Fávero (1993) e Fávero, Andrade e Aquino (2007) apresentam o tópico discursivo, em linhas gerais, como "aquilo sobre o que se está falando. Ele é “...um elemento estruturador da conversação, pois os interlocutores sabem quando estão interagindo dentro de um mesmo tópico, quando mudam, cortam, retomam ou fazem digressões.

Concordamos com Aquino (1991, p.65-66), para quem o tópico representa “...o sentido construído enquanto se fala e gerado, também, por atividades as quais o mobilizam e marcam os seus segmentos".

Jubran et ali(1992, p.361) afirmam: 
O tópico decorre de um processo que envolve colaborativamente os participantes do ato interacional na construção da conversação, assentada num complexo de fatores contextuais, entre os quais as circunstâncias em que ocorre o intercâmbio verbal, o conhecimento recíproco dos interlocutores, os conhecimentos partilhados entre eles, sua visão de mundo, o background de cada um em relação ao que falam, bem como suas pressuposições.

No momento da interação, quando dois ou mais interactantes estão engajados no processo, o tópico discursivo se estabelece, pela negociação que estes realizam. Fávero (op.cit) explica que o tópico discursivo pode ser estabelecido por marcas linguísticas e não linguísticas, por meio de marcas implícitas, que podem ser resgatadas por meio do contexto situacional.

Nesse caso, as unidades linguísticas utilizadas referem-se sistematicamente a traços do mundo extralinguístico (FÁVERO, ANDRADE E AQUINO: 2007). Esses traços não só fazem referência ao contexto imediato, mas ao conhecimento partilhado de mundo de que os interlocutores dispõem no momento da interação.

As autoras exemplificam essa questão com a conversação ocorrida entre um casal que combinara ir à praia para passar o fim de semana, e o marido (L1), que esperava à porta do elevador, impacientou-se com a demora - tão costumeira - da esposa (L2). Indignado, mas tendo o cuidado para não criar indisposição entre eles, dirigiu-lhe a palavra:

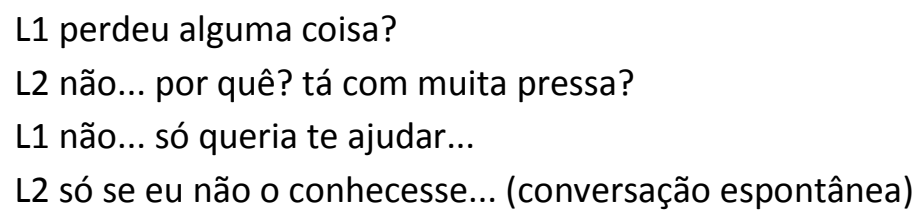

Segundo as pesquisadoras, ao perguntar se havia perdido alguma coisa, na verdade L1 estava querendo referir-se à demora da esposa e foi assim que ela inferiu, devido ao conhecimento partilhado de que os dois dispunham. Assim, L2 responde com outra pergunta, mostrando ao interlocutor o que havia inferido. Sem querer criar indisposição, L1 disse que só queria ajudar. Novamente L2 se posicionou (só se eu não o conhecesse), indicando o que inferiu, não pelo que L1 explicitou, mas pelo pressuposto (FÁVERO 2007, p.38). 
O tópico é, assim, uma atividade construída cooperativamente, isto é, há uma correspondência - pelo menos parcial- de objetivos entre os interlocutores. É importante salientar que, durante o processo conversacional, os interlocutores precisam estar atentos e engajados no processo, a fim de perceber os tópicos explícitos e implícitos.

Um trabalho importante para a compreensão do tópico discursivo é o de Jubran et ali (1992), para quem o tópico discursivo é uma unidade abstrata e relacional, caracterizada pelas propriedades de centração e organicidade.

Para os autores, a centração abrange a concernência (relação de interdependência semântica entre os enunciados), a relevância (proeminência desse conjunto, decorrente da posição focal assumida pelos seus elementos) e pontualização ( localização desse conjunto, tido como focal, em determinado momento da mensagem).

Aquino(1991, p.72) afirma:

“...a delimitação do tópico é norteado pelo pelo princípio de centração, de tal forma que um tópico se diferencia de outro no momento em que se observa uma nova centração, a qual se distingue da centração do tópico anterior".

Para apontar os tópicos em um processo dialógico, o pesquisador deve voltar sua atenção para "sobre o que se fala" e para os fatores linguísticos e pragmático-contextuais que também atuam na estruturação interna e ocorrência no discurso.

Assim, segundo os autores, o ponto central está no fato de o tópico possuir uma organização hierárquica, centrada em aspectos temático-estruturais de camadas, onde as mais abrangentes contêm outras, mais específicas ou particularizadas, de modo a se materializar em segmentos tópicos - unidades discursivas que atualizam as propriedades do tópico.

Concordamos com os autores quando afirma que a topicalidade é um organizador do discurso, sendo possível descrever seu comportamento na linearidade do discurso em termos de continuidade e descontinuidade, ambos ligados à progressão temática.

É importante o entendimento do tópico discursivo, pois este possibilita um refletir sobre a organização da conversação enquanto fenômeno social, de forma que o pesquisador - ou mesmo os interlocutores da conversa - possam identificar quando um tópico tem 
início, ou quando é mudado, cortado, retomado, tem digressões. É por meio do tópico que podemos encontrar e analisar aspectos da continuidade tópica ou descontinuidade, na observação linear do discurso.

Nesse aspecto, Koch et ali (1990) observam que "teremos em conta, no tratamento da progressão temática, a atuação de fatores diversos, associados ao contorno pragmático do discurso oral, que se manifestam na organização da informação e na apresentação formal da unidade discursiva" (p.146).

A unidade discursiva é tomada, na visão dos autores, como um "fragmento textual que se caracteriza pela centração em determinado tema, podendo ser compreendido pelos subtópicos em que se divide o supertópico global”. (p.146)

O desenvolvimento da conversação, segundo Jubran et ali (op. cit.), permite que se perceba a progressão temática, a mudança de tópico, por meio do fechamento de um tópico e início de outro - continuidade. Por outro lado a descontinuidade é perceptível quando há uma ruptura ou desequilíbrio na sequência do discurso, que pode ocorrer por meio de interrupção e abandono definitivo do assunto ou por uma inserção temporária de um tópico.

A constituição de supertópicos, tópicos e subtópicos estabelece o que Jubran et ali (op.cit) conceituam o "Quadro Tópico", como uma organização temática discursiva organizada em torno de um supertópico. Assim, é possível, numa conversação, encontrarmos vários quadros tópicos, conforme exemplifica a imagem a seguir:

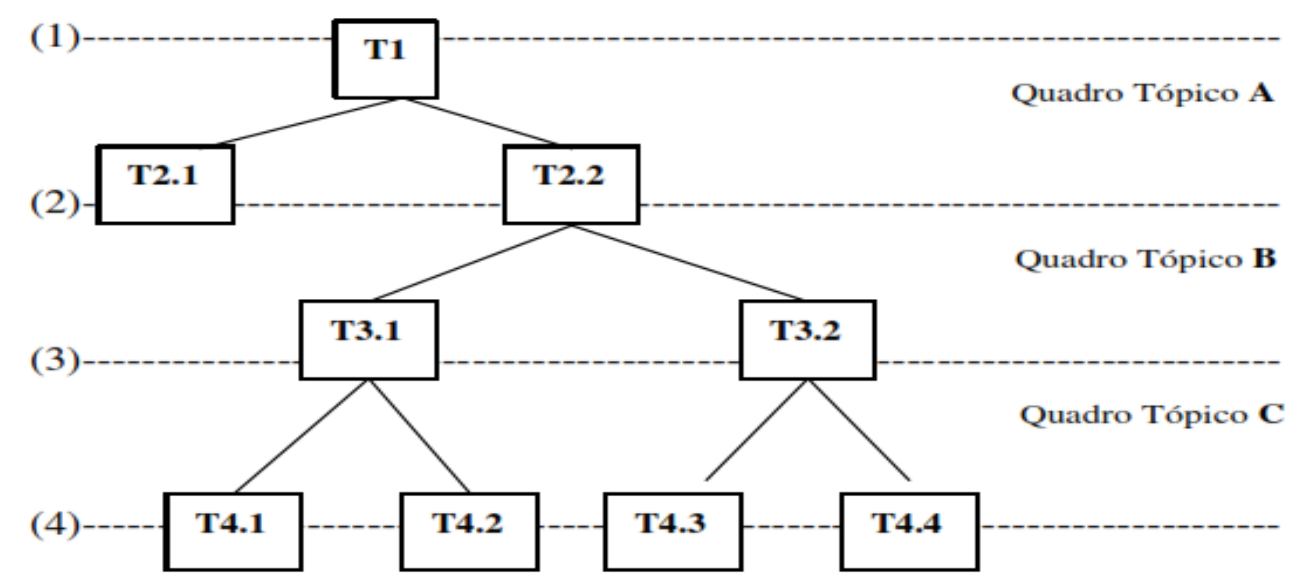

Figura 5. Organização Tópica (JUBRAN et ali:1992) 
É importante ressaltar que Jubran et ali afirmam ser o quadro tópico um procedimento metodológico que o pesquisador se vale para localizar e analisar quais são os tópicos subordinadores e os subordinados: trata-se de um procedimento que relaciona e organiza a progressão discursiva.

\subsubsection{Propriedades do Tópico Discursivo}

\subsubsection{Centração}

Se pensarmos no tópico como o "conteúdo" da conversa, não podemos conceber a conversação sem ele. Para tanto, os interlocutores devem estar "centrados", engajados para perceber a utilização de referentes explícitos e inferidos durante o desenvolvimento textual.

Quanto à centração, Jubran et ali (1992, p.361-362) destacam fundamentalmente a referencialidade textual: o tópico é tomado no sentido geral de "acerca de" que se fala, isto é, "um conjunto de referentes explícitos ou inferíveis concernentes entre si e em relevância num determinado ponto da mensagem" (p. 361) - o que leva a uma associação de tópico com a função representativo-informacional da linguagem. Para os autores, a centração, envolve traços de:

(i) concernência, isto é, "interdependência semântica entre os enunciados";

(ii) relevância, que diz respeito à "proeminência de um certo conjunto de enunciados"; e

(iii) pontualização, isto é, a possibilidade de localização de um determinado conjunto de enunciados dentro de uma mensagem.

Segundo Fávero (1993, p.40), centração "é o falar-se acerca de alguma coisa, implicando a utilização de referentes explícitos ou inferíveis. O tópico tem limites bem definidos e pode ser distribuído em segmentos sucessivos...". A centração é de tal maneira importante para o tópico que, em se alterando a centração, ali aparece um novo tópico.

Koch (1998) esclarece que, durante um evento, os segmentos tópicos não seguem necessariamente uma progressão linear, podendo, numa sequência de enunciados, haver 
alguns que se referem ao tópico/subtópico em curso e outros que atencipam ou retomam subtópicos, respectivamente, que serão abordados ou já encerrados (cf. p.78).

\title{
2.4.1.2 Organicidade
}

Todo tópico discursivo se desenvolve de tal maneira que são inseridos subtópicos, ou seja, um "assunto" dentro de outro ligado ao central. Segundo Fávero (op.cit), a organicidade se estabelece quando temos um tópico central ou supertópico, que se desenvolve em subtópicos, em dois planos: linear e vertical.

Ainda segundo a autora, "a noção de linearidade refere-se às articulações entre tópicos em termos de proximidade da linha discursiva e está ligada à introdução de informações novas." (op. cit p.46).

Jubran et ali (1992, p.362) entendem a linearidade como a sequenciação, e a verticalidade como a hierarquização das unidades discursivas. Nesse sentido, afirmam que:

\begin{abstract}
Cada nível é recoberto por um superior e constituído por um inferior, sendo que os limites dos diversos níveis são dados pelo grau de abrangência do assunto em foco. Há como que camadas de organização, indo desde um tópico suficientemente amplo para não ser recoberto por outro superordenado, passando por tópicos sucessivamente particularizadores, até se lançarem constituintes tópicos mínimos - definíveis pelo maior grau de particularização do assunto em relevância.
\end{abstract}

O seguinte diagrama tópico ilustra de maneira clara as camadas desse sistema:

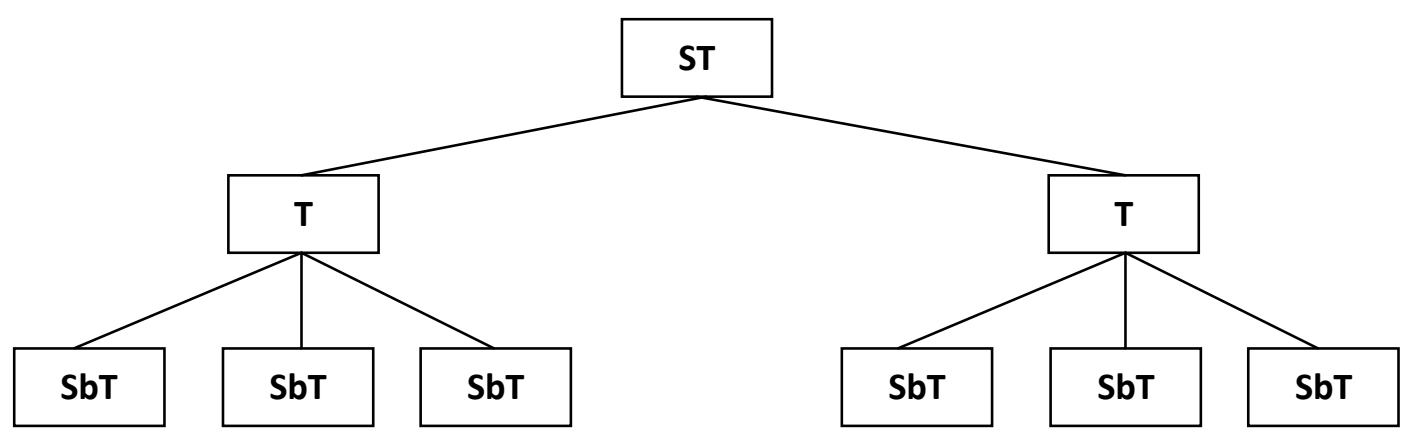

Figura 6. Diagrama Tópico 
Para Jubran et li (1992), essa organicidade diz respeito à relação hierárquica e de interdependência entre tópicos de uma ocasião de encontro social. Diversos níveis de organização podem ser traçados entre o conjunto de tópicos de uma conversa, estabelecendo-se o supertópico, para um nível mais abrangente, e subtópicos para níveis mais fechados, restritos do tema. Essa organização tópica leva ao desenho dos Quadros Tópicos apresentados acima, que, segundo a autora, possuem duas características essenciais:

(i) centração em um supertópico, que delimita a porção de discurso no qual um tópico é focal e;

(ii) divisão interna em subtópicos, isto é, tópicos co-constituintes de uma mesma camada de organização tópica.

Jubran et ali conceituam o quadro Tópico como uma noção abstrata e relacional, que se concretiza pela seleção hierárquica feita pelo analista para descrever um determinado corpus.

\subsubsection{Delimitação Local}

Todo tópico discursivo apresenta marcas verbais ou não verbais que evidenciam seu início, desenvolvimento e fechamento, e estas marcas podem aparecer na forma de marcadores conversacionais, elementos prosódicos (pausas e hesitações), perguntas retóricas, entre outras.

\subsection{Marcadores Conversacionais}

Os marcadores conversacionais são elementos que se prestam à demarcação do papel de cada interlocutor na conversação, e sua função precípua é a ligação entre unidades comunicativas. Marcam troca de turno, fim da elocução, correção de falhas, mudança de tópico etc. Em termos gerais, são mecanismos que atuam no nível do discurso (organização textual-interativa), mas que ainda não constituem uma classe bem definida.

Na literatura sobre o assunto, há, inclusive, uma ausência de consenso terminológico, pois é possível encontrar, referindo-se a esses mecanismos, expressões como marcadores 
conversacionais, operadores discursivos, marcadores de estruturação da conversação, apoios do discurso etc. Para este trabalho, adotaremos o termo Marcador Conversacional, alinhando a terminologia ao nosso objeto de estudo.

Marcuschi (2005) investiga os Marcadores Conversacionais, verificando que, quanto a funções específicas, cada qual pode ter funções sintáticas (responsáveis tanto pela sintaxe da interação quanto pela segmentação e pelo encadeamento das estruturas linguísticas) e funções conversacionais. No que se referem às funções conversacionais, esses marcadores podem ser analisados sob os seguintes aspectos:

i) sinais produzidos pelo falante, que servem para sustentar o turno, preencher pausas, dar tempo à organização do pensamento, explicitar intenções, indicar o início e o final de uma asserção, dúvida ou indagação, etc; e

ii) sinais produzidos pelo ouvinte, que servem para orientar e monitorar o falante. Estes sinais marcam a posição pessoal do ouvinte, encorajando-o, desencorajando-o, ou solicitando alguma informação a mais.

Assim, os Marcadores conversacionais podem atuar como elementos verbais, prosódicos (entonação, pausas, alongamentos de vogais) - e não linguísticos (paralinguístico) (riso, gesticulação). Marcuschi (1989, p.282) salienta que os marcadores têm um caráter multifuncional, pois operam como organizadores da interação, articuladores dos textos e indicadores de força ilocutória.

Marcuschi (1987) divide os marcadores conversacionais em:

1) marcador simples - uma só palavra;

2) marcador composto - apresenta um caráter sintagmático;

3) marcador oracional - corresponde a pequenas orações que se apresentam nos diversos tempos e formas verbais;

4) marcador prosódico - associa-se a algum marcador verbal, mas realiza-se por meio de recursos prosódicos.

Galembeck (2010, p.1570) afirma que todos os marcadores conversacionais " (...) exercem, genericamente, uma função textual, à medida que organizam e estruturam o texto. Essa função geral, porém, desdobra-se nas duas funções particulares indicadas a 
seguir: a função interpessoal e a ideacional. Essa duplicidade de funções faz com que existam dois tipos de marcadores: os interacionais (ou interpessoais) e os ideacionais (ou coesivos)".

Os interacionais representam a ligação entre os interactantes, estabelecem contato e sinalizam a pragmaticidade do ato, mantendo-o ou direcionando-o. Os ideacionais ligam porções de texto, dão continuidade ao fluxo sintático e discursivo, e também apresentam novos tópicos.

Seguindo essa linha, Risso et ali (1996, p.423) atestam que a natureza da ação discursiva dos marcadores conversacionais leva-os a se orientarem em dois planos: a) estrutura textual, com a organização da informação, e b) estrutura interpessoal, com a organização das relações entre os interactantes. Os marcadores conversacionais atuam, assim, no plano da enunciação textual interativa com funções tanto de promover processos interpessoais (quando o foco funcional não está na organização de partes do texto) quanto destacar a articulação textual (quando a prevalecente não se encontra mais no eixo da interação).

\footnotetext{
"A natureza da atuação discursiva dos assim chamados "Marcadores Conversacionais" permite distribuí-los (...) entre dois planos não necessariamente exclusivos, antes quase sempre interrelacionados, conforme seu envolvimento maior com a organização da informação, na estrutura ideacional do discurso, ou com a organização das relações entre os interlocutores, na estrutura interpessoal." (RISSO:1996, p.423)
}

Assim, os marcadores interpessoais possuem uma função diretamente ligada à situação interacional, face a face. Já os marcadores com função textual operam no nível da coesão, estabelecendo relações semânticas e sintáticas entre as unidades de discurso. Podem, dessa forma, permitir ações como abertura, expansão, retomada e fechamento de tópicos e diferenciação de estruturas de figura e fundo.

Fávero, Andrade e Aquino (2007) enfatizam que eles fazem parte da função interacional na conversação, articulando textos, encadeando-os de modo coeso, ligando partes do discurso e permitindo a progressão tópica. 


\begin{abstract}
"Constituem um elemento importante na articulação de textos, porque evitam que a conversação se torne uma sucessão de monólogos paralelos. Porém, na medida em que encadeiam um texto de modo coeso, os marcadores também o segmentam. Percebe-se que eles agem como elementos de segmentação ao mesmo tempo em que suprem, em certa medida o papel de pontuação na fala." (p.46)
\end{abstract}

Segundo Urbano (1993), os marcadores conversacionais são elementos de variada natureza, dimensão, estrutura, complexidade semântico-sintática, aparentemente supérfluos ou até complicadores, mas de indiscutível significação e importância para qualquer compreensão do fenômeno conversacional.

O autor acredita que esses elementos não fazem parte do conteúdo cognitivo ou conteúdo informativo do texto, mas ajudam a construir e dar coesão e coerência à conversação. São na realidade articuladores conversacionais, marcando e revelando as condições de produção desse tipo de texto. Apresenta o aspecto formal dos marcadores e divide em quatro categorias:

a) linguísticos (verbais e prosódicos)

b) não linguísticos (olhar, risos, etc.)

c) Simples, compostos ou complexos (sabe? quer dizer, no fundo...)

d) Oracionais e combinados (acho que..., mas acho que....)

Os marcadores linguísticos, geralmente, são estereotipados (né?, tipo assim, entre outros), são usados por ambos os interlocutores no ato conversacional e sua característica é não trazer nenhuma informação nova para o encadeamento conversacional. Podem aparecer no início, no meio ou no fim do turno.

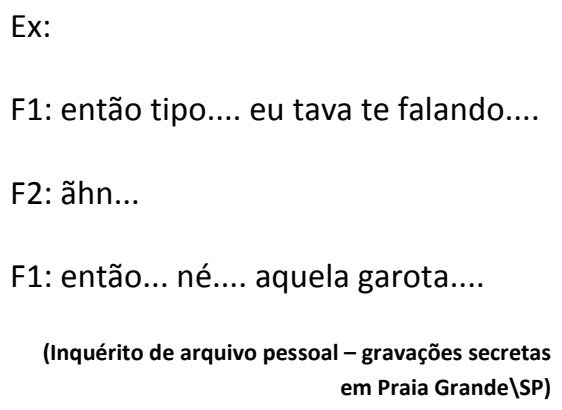


Servem para encadear o ritmo e o tom da conversação, ou seja, organizar o discurso, podendo ser utilizado para discordar, concordar ou perguntar, mudar de argumento, manter a atenção ou retificar ou ratificar os atos de fala.

Os marcadores conversacionais sustentam o turno, preenchem silêncios, monitoram o ouvinte, marcam unidades temáticas, indicam início e fim de asserções, dúvidas, indagações, antecipam o que será dito, corrigem ou apagam posições anteriores, reorganizam e orientam o discurso.

\section{Exemplos:}

Tomada de turno: olhe, certo mas, a propósito;

Sustentação de turno: sabe?, viu?, entende?;

Saída ou entrega de turno: é isso aí, que acha?;

Armação do quadro: agora que estamos nesse assunto, por falar nisso;

Assentimento ou discordância: hum, ahã, ué, não não;

Abrandamento: odeio dizer essas coisas, devo informar que;

Quanto à posição no turno, os marcadores classificam-se em:

Iniciais: não, mas, acho que, não é assim, que caracterizam o início ou a tomada de turno.

Mediais: né?, sabe?, entende?, digamos, advérbios, conjunções, alongamentos, que são responsáveis pelo desenvolvimento do turno.

Finais: né?, não é?, entendeu?, perguntas diretas, pausa conclusa, que assinalam a passagem implícita ou explícita do turno.

A posição dos marcadores não é fixa, ou seja, o mesmo marcador pode aparecer em diferentes posições; eu acho que (inicial e medial); não é? (medial e final), podendo, inclusive, se sobrepor quanto às funções desempenhadas na conversação. 


\subsection{Procedimentos de formulação e reformulação do texto falado.}

Textos escritos e falados são produzidos a partir de estratégias de formulações. Os procedimentos de formulação podem ser entendidos como sendo processos linguísticodiscursivos dos quais os falantes se utilizam para produzir seus enunciados.

O texto escrito padrão, no entanto, não permite que se percebam as marcas de sua elaboração, pois é produto de um pensar e repensar sobre o que se vai imprimir ali. Apresenta-se acabado, coeso, com sequência temporal e é planejado a partir da reflexão linguística acerca dos termos mais adequados, a articulação mais clara, dados específicos, entre outros.

Marcuschi (2005, p.28) afirma que "ao escrevermos, dispomos de mais tempo que na conversação. Podemos voltar atrás corrigindo os equívocos, eliminando passagens supérfluas, refazendo o estilo e polindo o texto. O leitor só recebe a versão final." As atividades de formulação da fala (repetição, correção, hesitação, etc) não aparecem na escrita, já que quem escreve não deixa que as correções realizadas durante o processo construtivo apareçam em seu texto. Há, ainda, uma tendência para a ocultação das hesitações e o menor uso possível de repetições.

O texto falado, por sua vez, tem como uma de suas características mais marcantes o planejamento local, ou seja, a organização imediata e a utilização, durante o processo, de alguns fenômenos inerentes à construção verbal, como truncamentos, hesitações, correções, pausas, elementos importantes no processo de estruturação e organização textual verbal.

Diante dessas características peculiares, o texto conversacional muitas vezes aparenta ser pouco elaborado em relação ao escrito, uma vez que, no ato de fala, é possível notar as nuances, estratégias e procedimentos de estruturação na sua construção, que nunca finaliza, está sempre em progresso.

De acordo com Chafe, citado em Rodrigues (1993), “...a língua falada espontânea(...) é produzida aos jatos, aos borbotões, que são unidades de ideias, (...) com um contorno entoacional típico, e limitado por pausas. A passagem de uma unidade para outra é feita muito rapidamente, o que torna o processo de falar bem mais acelerado do que o de escrever"(p.21). Essa consideração aponta para a questão do planejamento que, na escrita, 
vai desde o tema a ser desenvolvido ao planejamento linguístico-discursivo, e implica a articulação de ideias e de aspectos linguísticos.

Conforme se pode notar no exemplo acima, a fala espontânea é entrecortada de muitas pausas e alongamentos, que servem de base para a estruturação do texto. Este, por sua vez, pode parecer sintaticamente desorganizado, pois as frases são incompletas, mas há de se convir que em grande parte do tempo esses cortes fazem parte de uma estratégia para uma posterior retomada da ideia, geralmente reestruturada.

Halliday (1985) nos esclarece que a fala não é "pobre em conteúdo", ou seja, não há falta de informação e geração de ideias, tampouco desestruturada ou superficial. A questão da aparente falta de estruturação da fala se dá no momento da transcrição, na qual é colocada num plano e suporte que, por natureza, não lhe pertence.

Se no momento da elaboração de um texto escrito, colocássemos todas as formas de planejamento e replanejamentos de que nos dispusemos para produzi-los, certamente também pareceria desconexo.

Dessa maneira, é mister dizer que a fala não é menos organizada do que a escrita, e que se trata de uma forma de organização altamente estruturada e necessita, portanto, de uma investigação focada também nos processos de produção.

Assim, as estratégias de formulação da fala têm a função geral de garantir a intercompreensão conversacional, proporcionando a progressão tópica e discursiva, explicitando e especificando, ou mesmo resumindo ou denominando informações, bem como adequando termos ou apontando-Ihes outros sentidos no fluxo conversacional.

No desenvolvimento da interação, o falante, frequentemente, se depara com problemas de formulação, os quais se apresentam em forma de descontinuidades do fluxo formulativo, e são explicitadas de forma linguística ou paralinguística.

Nesse sentido, Koch et ali (1990)observam que "... o fluxo de informação pode-se desenrolar com naturalidade, de modo contínuo, e, portanto, mais rápido; pode, também, ser obstaculizado, dando origem a descontinuidades, que conferem um ritmo ralentado à progressão temática"(p.146).

Para os autores, 


\begin{abstract}
"no dinamismo do envolvimento interacional em que a atividade verbal se desenvolve, pode-se avaliar com nitidez a capacidade ativa do locutor de planejar momentaneamente sua comunicação, procedendo, de forma estratégica, a inserções, reconstruções e quebras na sequência de seu discurso. (p.149)"
\end{abstract}

Para Hilgert (1993, p.108), “a característica mais evidente do texto falado é a grande incidência de descontinuidades no curso de sua formulação. A descontinuidade, como o termo já diz, consiste numa interrupção do fluxo formulativo...".

Ainda segundo o autor, essa interrupção do fluxo formulativo caracteriza um "problema de formulação", e se divide em dois eixos: problemas prospectivos (quando o falante se dá conta deles antes de os formular) e retrospectivos (quando já foram enunciados linguisticamente e estão no texto). Entre os problemas prospectivos, podemos citar a Hesitação e a Repetição, e entre os retrospectivos, estão a Correção e Reformulação.

\title{
2.6.1 Hesitação e Repetição
}

Os problemas prospectivos, conforme dito anteriormente, são aqueles constatados pelo falante antes de serem verbalizados. O falante explicita a dificuldade de formulação por meio de rupturas no fluxo formulativo, por meio de recursos diversos, como pausas, alongamentos e elementos paralinguísticos.

A Hesitação e a repetição são consideradas problemas de formulação prospectivos, uma vez que aparecem antes de serem formulados.

Jubran (2006, p.34) afirma que a hesitação, bem como a interrupção, são "fenômenos intrínsecos da oralidade", "que não se constituem propriamente como estratégias de formulação textual, e sim como atividades de processamento online."

Marcuschi (2006) indica que a hesitação é constituída por pausas (preenchidas ou não); alongamentos, fragmentos lexicais e marcadores discursivos hesitativos quase sempre alongados e preenchedores de pausas. $\mathrm{O}$ autor entende como tipos de hesitação as pausas não preenchidas, as preenchidas, as repetições hesitativas e os falsos inícios (quebras lexicais, por ex.). 
Quanto ao papel desempenhado pela hesitação, ele afirma: “A rigor, tudo indica que o papel cognitivo das hesitações é primordial, indiciando uma atividade de processamento da fala e atividades de enunciação" e "seu papel é muito mais o de sugerir os sintomas de um processamento em curso" (MARCUSCHI 2006, p.66-67). Nos estudos realizados pelo autor, este considera importante esclarecer que a hesitação não é uma simples disfunção da fala ou um "defeito", pois pode ser um descontinuador da "materialidade" textual, mas não é descontinuador do discurso, da produção de sentidos. Fazem, outrossim, parte da competência comunicativa em contextos interativos de natureza oral e não podem ser considerados uma disfunção do falante, mas constituintes de natureza interacional.

A hesitação tem como característica fundamental o fato de indicar evidentes cortes da fala, em pontos não previstos por fatores sintáticos ou prosódicos aleatórios, mas não formando uma dicotomia entre fluência discursiva e continuidade.

Segundo Koch et ali. (1990), " tanto as interruções definitivas, como as suspensões momentâneas do tema acusam a forte tendência da língua falada para explicitar os processos de sua própria criação, diferentemente da língua escrita, que geralmente os esconde, mostrando apenas o resultado lapidado". (p.149)

As hesitações podem apresentar determinados fenômenos tais como: fenômenos prosódicos que são pausas prolongadas e alongamentos vocálicos, expressões hesitativas que aparecem com o objetivo de dar tempo ao locutor para formular sua construção, marcadores conversacionais repetidos, entre outros. No exemplo abaixo, destacamos com sublinhado e negrito alguns exemplos de marcas de hesitação:

Inf. e ela ficou no hospita::I durante cerca de vinte dias...e eu fiquei na mão de uma empregada que:: QUANdo se lembrava dava mamadeira...quando não se lembrava não dava...quando se lembrava de ver se o leite estava bom ela via se não o leite ia estragado mes::mo::...nessas condições quando minha mãe voltou da ma/ do hospital... eu estava num estado de::subnutrição de fraqueza que o::próprio médico pediatra...achou um abSURdo...isso... brigou com minha mãe devido o fato de...de me ter deixado...

(PROJETO NURC/SP INQUÉRITO № 208 - BOBINA № 79 - INF. № 252) 
A repetição está intrinsecamente ligada ao processo de hesitação. Koch (1998, p.100) afirma que "a repetição engloba desde a repetição 'exata' até aquela em que ocorrem variações maiores ou menores na forma e, portanto, também a paráfrase". No exemplo acima, na penúltima linha, vemos um exemplo de repetição exata, que demonstra uma hesitação do falante ao terminar seu ato enunciativo.

Marcuschi (1996, p.96), entende que a "a repetição não é um descontinuador textual, mas uma estratégia de composição do texto e de condução do tópico discursivo". A repetição, assim, constitui-se em uma estratégia de formulação da fala, sendo um produto material do reflexo do próprio processo interativo desenvolvido.

O autor considera a atuação da repetição no plano da textualização e no plano discursivo. O plano da textualização caracteriza-se por ser o plano em que as repetições agem na totalidade e na sequenciação das cadeias linguísticas. O plano discursivo caracteriza-se por ser de caráter mais global, relacionando-se aos aspectos interacionais, cognitivos e pragmáticos.

As repetições teriam, no plano textual, uma função coesiva, de caráter produtivo para o encadeamento textual. Marcuschi cita a listagem como estratégia mais geral, onde uma estrutura base é repetida em sua totalidade ou com algumas variações lexicais. Essa estratégia do falante permite manter o ritmo na interação, criando envolvimento deste com o enunciado.

Já no plano da interação, a repetição apresenta uma diversidade maior de funções, e colabora para a continuidade tópica, para a compreensão e para a argumentatividade.

\subsubsection{Atividade de Reformulação: correção}

Durante o processo interacional, há momentos em que o falante precisa readequar seus atos enunciativos, no plano do material linguístico utilizado, uma vez que o jogo interacional exige, por algum motivo, geralmente porque utilizou um termo ou expressão considerada inapropriada para o que pretendia dizer. A esse processo de reconstrução da sequência discursiva damos o nome de correção ou reparo. 
Para Barros (1993, p.136), “a correção é (...) um procedimento de reelaboração do discurso que visa a consertar seus erros. O 'erro' deve ser entendido como uma escolha do falante - lexical, sintática, prosódica, de organização textual ou conversacional..."

Koch (1998) afirma que "a reconstrução consiste em uma reelaboração da sequência discursiva (...) que provoca também a volta de elementos já veiculados, ou seja, é como se ocorresse uma 'patinação' na progressão discursiva" (p.97)

Segundo Koch (1990), o reparo, dentro do processo de reconstrução do enunciado, representa um grau superior ao da repetição stricto sensu, pois a repetição ocorre, mas apresenta algumas diferenças no que diz respeito à função: a repetição atrasa a formulação do enunciado, evidenciando a elaboração deste, enquanto o reconstrói, após ter sido enunciado.

\footnotetext{
"O falante trunca o enunciado e o retoca, com o objetivo de substituir uma primeira formulação por outra, mais pertinente aos seus objetivos comunicativos. Está nessa substituição, que implica a exclusão de uma escolha anterior, o traço que com mais evidência particulariza o reparo". (KOCH:1990, p.163)
}

Sua função é formular ou reformular melhor um segmento maior ou menor do texto produzido, para sanar problemas, localizados pelo próprio falante ou pelo interlocutor (BARROS:1993, p.98).

Por fim , a correção pode ser considerada como um conjunto de "atos de constituição do texto falado", que vão desde a escolha das palavras adequadas até a organização do discurso.

Segundo Favero, Andrade e Aquino (2007, p.63), a correção tem um papel muito importante no processo de elaboração do texto. Podemos dizer que ela corresponde à construção de uma parte da conversação que permite reformular algo anteriormente expresso que pode ser mal compreendido ou considerado "erro" pelo ouvinte. Nessa direção, as autoras afirmam que a correção é "um claro processo de formulação retrospectiva".

Assim sendo, este processo engloba a correção da palavra considerada inadequada ou truncada - o falante as articula de maneira errônea, hesitando em prosseguir com sua 
utilização no discurso - , e as negações, quando o falante simplesmente as considera inadequadas, e as troca por outras que considera mais adequadas.

F1: O professor pediu pra $\underline{\operatorname{mim}}$ fazer a prova... pra eu fazer a prova... é eu ou mim?

Doc: do seu jeito... ((risos)) a norma padrão diz que é pra eu fazer... ma::s... você fala do seu jeito agora.... e então... o que aconteceu? Você fez a prova? (Inquérito de arquivo pessoal - gravações secretas em Praia Grande (SP - grifos meus)

Para Barros (1993), há dois tipos de correção: a reparação, que é uma correção de uma infração conversacional, e a correção propriamente dita, que diz respeito aos atos de reformulação do enunciado, consertando "erros" e assegurando a intercompreensão do discurso.

Os atos de reparação são próprios da conversação face a face prototípica, onde os falantes estão presencialmente juntos, e cometem infrações de assalto aos turnos, dominando, por vezes, a conversa em curso. Este tipo de correção não será abordado neste trabalho, uma vez que nosso objeto de estudo, as conversações digitais, pressupõem que os interlocutores não estejam face a face, mas "tela-a-tela", ou seja, em ambientes físicos distintos. 


\section{CAPÍTULO III \\ A organização da conversação digital no MSN}

\subsection{Conversação Digital: fenômeno cibercultural}

A conversação deve ser entendida, antes de qualquer consideração, como um evento social, uma prática inerente ao homem. Em qualquer agrupamento humano, pode se observar o fenômeno conversacional, que se organiza de acordo com normas e convenções sociais próprias da comunidade em que se encontra.

É somente por intermédio dessa organização interacional que os indivíduos podem ser considerados "sociais", pois desempenham seus papéis e constroem, mutuamente, imagens acerca de si e dos outros com os quais compartilham ideias e informações diariamente.

Retomando Silva (2008), onde afirma que a conversação é uma prática social que prescinde todas as outras práticas na vida social, podemos dizer que o homem só é social porque conversa. Por meio da conversa, relacionam-se e assumem compromissos sociais, buscando, de diversas maneiras, atingir seus propósitos pragmáticos.

Assim, não é precipitado afirmar que a conversação é mais que uma ferramenta, é, sobretudo, condição para que o homem construa sua identidade e viva em sociedade, constituindo-se cooperativamente como um membro de grupo social.

O século XXI está sendo marcado por grandes avanços no que diz respeito às práticas interativas e eventos comunicativos por meio da cibercultura, fenômeno cultural que alia organização social, partilha de normas e convenções à modernidade.

A portabilidade (celulares, tablets, netbooks, etc) e a possibilidade de estar em linha a todo o momento com as pessoas de seu círculo social contribuem para que a conversação digital via MSN , entre outros, se consolide como uma manifestação comunicativa coletiva. Seu uso já é efetivo em empresas, para troca de informações em tempo real com setores e 
departamentos interligados, e nos lares, onde os membros da família podem estar em contato constante entre si.

Isso acontece graças à possibilidade de instalação de softwares que dão acesso às redes sociais, troca de mensagens e comunicadores instantâneos nos celulares do tipo smartphone. Acreditamos que, nesse tipo de conversação, "um sistema de práticas, convenções, regras de comportamento é empregado" (GOFFMAN:1970, p.10).

O que apresentamos aqui, portanto, é uma análise desse mecanismo de autoorganização, procurando delinear, na perspectiva da Análise da Conversação, o que as pessoas fazem ao interagir nesse meio, buscando os princípios de organização da conduta interacional no ambiente virtual. Nossa preocupação é verificar de que maneira as pessoas realizam suas ações sociais e dão sentido ao mundo à sua volta.

\subsection{A questão do turno conversacional: uma proposta de releitura para a análise digital: o Ato Enunciativo Digital (AED)}

Um dos principais fenômenos que distinguem a conversação face a face da conversação digital, em termos de estrutura interacional, é a noção de turno. Para muitos estudiosos, como Marcuschi (2005, p.18), a tomada de turno é uma operação básica da conversação, e o turno é um dos componentes centrais do modelo. O autor conceitua turno como aquilo que o falante faz ou diz enquanto tem a palavra, incluindo a possibilidade do silêncio.

Galembeck (1993) deixa clara a importância do turno para a conversação, quando explica que ele garante a alternância dos membros durante a interação, condição necessária para que esta se instaure.

Mesmo considerado como o elemento fundamental da conversação, a ideia de turno no ambiente virtual se desintegra diante de duas características evidentes desse tipo de interação: desde a ausência física dos interlocutores no mesmo espaço à não utilização da voz como meio de transmissão de informações. A voz permite o "assalto ao turno", a "tomada da vez", e a expressão corporal, no diálogo, colabora para que isso ocorra.

A regra "fala um por vez", considerada por Marcuschi como o principal mecanismo da conversação, não se fundamenta no plano virtual. Nas trocas eletrônicas, notamos que os 
atos de fala não seguem o roteiro esperado pela regra prototípica da conversação (A-B-A-B). Marcuschi (2005, p.19) afirma que “a regra básica é válida para a maioria das línguas, culturas e situações", mas deixa claro que essa regra é constantemente violada.

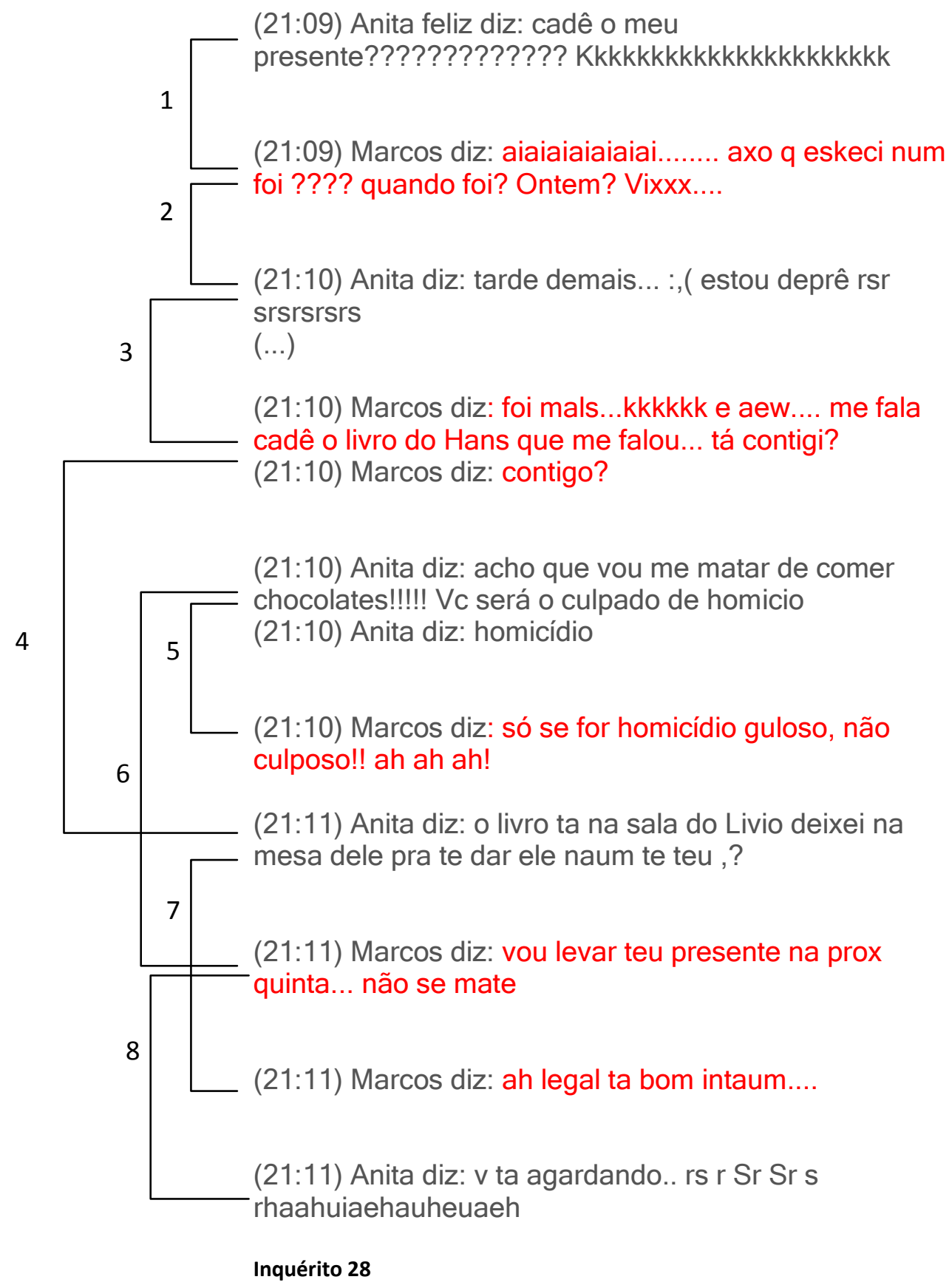

À primeira vista, a conversação digital inicia basicamente com um sistema de turnos alternados, do tipo "cumprimento-cumprimento" ou "pergunta-resposta", como foi o caso do exemplo anterior, mas o desenvolvimento da conversação permite-nos verificar que o 
modelo baseado em "tomadas de turno" não dá conta de explicar os fenômenos interativos desta natureza. Os interlocutores emitem perguntas, respostas e comentários a todo instante, sem considerar a necessidade de esperar uma interação, ou uma resposta, para que continue a progressão do tópico. Vão "falando", emitindo opiniões, fazendo gracejos, respondendo e lançando novos tópicos ao longo do evento, numa clara violação à noção tradicional de turno (falar um de cada vez).

Se tomarmos o exemplo anterior, os pares 1, 2 e 3 apresentam uma organização natural, uma pergunta, e, logo em seguida, uma resposta. A partir do par 4 , no entanto, a profusão de atos de fala deixa evidente que os interlocutores "digitaram" suas interações quase ou ao mesmo tempo, sem esperar pelas respostas de seu par.

Ao que parece, enquanto o interlocutor Marcos digita sua resposta no par 3 , e prepara o subtópico de 4, Anita já digitava outra inserção (que desencadeará nos pares 5-6), respondida em dois momentos diferentes.

Marcos interage com o comentário feito por Anita em 5, enquanto esta responde à interação feita anteriormente (4). 0 par 7 indica a compreensão de Marcos quanto à sua questão sobre o livro, e em 8 há evidência da compreensão de Anita acerca do presente que será ofertado pelo amigo.

Aparentemente caótica, essa forma de organização dos atos de fala é naturalmente compreendida pelos interactantes no momento da elocução. Um aspecto que pode ser associado entre os dois tipos de interação é que a conversação digital obedece basicamente a um sistema de turnos do tipo "Pergunta-Resposta", podendo haver também outros tipos de pares conversacionais, porém menos frequentes, como o tipo "conviteaceitação/recusa", no exemplo abaixo:

Alexandre ** Vulgo Xandão** diz: vc quer ir no shopping hj? (...)

Marco Antonio diz: ah to um pouco cançadp e tenho q ler sobre exclusao de ilicitude Inquérito 25

$\mathrm{Na}$ conversação digital, os papéis de "falante/digitador" e "ouvinte/leitor" apresentam uma dinâmica diversa daquela que ocorre geralmente na conversação face a 
face. Existe o ato de fala, mas não pode ser considerado um "turno" no sentido tradicionalmente encontrado.

A regra "fala um de cada vez" nem sempre se aplica. Esta pode ocorrer com frequência, mas vimos que há casos em que o interlocutor "projeta" diversos enunciados do tipo questionamento, assertivas, entre outros, e o leitor/interlocutor vai respondendo na sequência em que aparecem, não havendo um controle sobre o "turno" de um ou de outro interlocutor.

O trecho abaixo nos mostra uma sequência de atos que poderiam ser considerados, sob a perspectiva tradicional, "turnos" centrais e inseridos, além da ocorrência do fenômeno da projeção de diversos turnos seguidos:

Marco Antonio diz: mas vc vai fazer oq lê

Marco Antonio diz: quem vai c vc

Marco Antonio diz: o tiago tbm vai?

Alexandre **Vulgo Xandão** diz: catar umas minas

Alexandre **Vulgo Xandão** diz: eu e o tiago

Alexandre **Vulgo Xandão** diz: lógico

Marco Antonio diz: hummmm

Alexandre **Vulgo Xandão** diz: Assim a gente num demora... rs rs rs

Marco Antonio diz: certo rs

Inquérito 25

Diante dessas questões, podemos dizer que o conceito de turno se perde, pois não há possibilidade alguma de realizar uma gestão de turnos nesse contexto, sendo necessária uma reflexão que nos permita a explicação teórica dos procedimentos interacionais acima referendados.

Retomando Marcuschi (2005, p. 17), citando Sacks, Schegloff e Jefferson, para qualquer conversação é de se esperar que apresente o seguinte:

a) a troca de falantes recorre ou pelo menos ocorre;

b) em qualquer turno, fala um de cada vez;

c) ocorrências com mais de um falante por vez são comuns, mas breves;

d) transições de um turno a outro sem intervalo e sem sobreposição são comuns; longas pausas e sobreposições extensas são minoria; 
e) a ordem dos turnos não é fixa, mas variável;

f) o tamanho do turno não é fixo, mas variável;

g) a extensão da conversação não é fixa nem previamente especificada;

h) o que cada falante dirá não é fixo nem previamente especificado;

i) a distribuição dos turnos não é fixa;

j) o número de participantes é variável;

k) a fala pode ser contínua ou descontínua;

I) são usadas técnicas de atribuição de turnos;

m) são empregadas diversas unidades construidoras de turno: lexema, sintagma, sentença, etc.

n) certos mecanismos de reparação resolvem falhas ou violações nas tomadas.

Se tomarmos essas proposições como verdadeiras, e tentarmos colocar a conversação digital sob análise segundo esse sistema, haveria no mínimo as seguintes incompatibilidades:

\begin{tabular}{|l|l|}
\hline \multicolumn{1}{|c|}{ Esperado } & \multicolumn{1}{|c|}{ Na conversação digital } \\
\hline a) em qualquer turno, fala um de cada vez; & $\begin{array}{l}\text { Os interlocutores, por não estarem presentes no } \\
\text { mesmo espaço físico, podem lançar diversos } \\
\text { "turnos", inclusive sem esperar resposta do } \\
\text { b) ocorrências com mais de um falante por vez são } \\
\text { comuns, mas breves; }\end{array}$ \\
\hline
\end{tabular}

Tabela 6: incompatibilidades entre o sistema de conversação prototípico e a conversação digital.

Tomemos o seguinte exemplo como referência para as reflexões que seguintes:

[18:34] Nece@ilha diz: fala Govani,, o q vc vai fz no fim de sman?

[18:34]Nece@ilha diz: semana ahuhauhauhaehehue

[18:34] GustavoG. diz: Bibo, onde está o albun de figunhs?

[18:34] Nece@ilha diz: vai n Shopp?

[18:34] Nece3@ilha diz: ou vai fik em casa?

[18:34] GustavoG. diz: vix, nem sei...tvz fique em casa... o albo tá co Kevin?...

[18:34] Nece@ilha diz: tá cmg

Inquérito 30 
O que temos no exemplo acima é que o interlocutor 1 (Nece@ilha) lança diversos "turnos" no mesmo momento, sem esperar resposta do interlocutor 2 (GustavoG.), que, por sua vez, lança outro em forma de pergunta, e o interlocutor 1, ignorando a pergunta do Interlocutor 2, insiste em sua pergunta inicial.

Em seguida, o interlocutor 2 responde à solicitação feita pelo interlocutor 1, mas insiste em seu "tópico", perguntando se o álbum estaria com Kevin, o que o Interlocutor 1 responde dizendo que está com ele. Todo o evento conversacional acima se dá em um minuto, ou seja, em tempo real e numa velocidade relativamente rápida.

Nota-se que a noção tradicional de turno conversacional, quando aplicada ao contexto digital, apresenta alguns problemas que a análise da conversação digital deve entender, explicar e apontar alguns caminhos para as pesquisas nessa direção.

Até certo ponto, pode-se dizer que não há problemas com a definição original, pois o turno é mesmo "qualquer intervenção dos interlocutores (participantes do diálogo), de qualquer extensão" (GALEMBECK:1993). Há também consonância quanto aos pares conversacionais (ou adjacentes) do tipo pergunta-reposta, convite - aceitação/recusa, cumprimento-cumprimento, xingamento-defesa/revide, etc, tal como podemos verificar nos exemplos apresentados.

O problema central se coloca quanto à regra máxima da conversação: "falar um de cada vez". Marcuschi (2005) vê essa máxima como um fator disciplinador da atividade conversacional, pois nem todos falam ao menos tempo: em geral espera-se o outro concluir ou um não fala sozinho o tempo todo. A tomada de turno torna-se, assim, elemento importante para a organização da conversação face a face, conforme dissemos atrás.

O que se verifica aqui é que essa máxima é plausível apenas em se tratando de conversação face a face convencional, quando a sobreposição das vozes (canal) torna impossível a intercompreensão entre os interlocutores. Em outras palavras, usando a voz como canal, os interlocutores não podem sobrepor seus atos de fala, pois não seria possível captar as diversas mensagens simultaneamente, o que causaria um caos conversacional: ninguém entenderia ninguém, e todos quereriam o turno para si ao mesmo tempo. Enfim, não haveria centração, elemento importante para a organização conversacional. 
No contexto digital, o canal traz uma concepção escrita, o que nos permite, em tempo real, fazer diversas enunciações e esperar que nosso interlocutor, ao lê-las, vá respondendo e interagindo ao passo que vai respondendo, e, ao mesmo tempo, coloque novas propostas de interação (novos tópicos).

Essas intervenções representam enunciações, no sentido atribuído por Fiorin (2005), ou seja, uma instância linguística pressuposta pela existência do enunciado. Segundo Fiorin, se há um enunciado, há uma enunciação pressuposta. A enunciação é, portanto, o ato de produção do discurso, é uma instância pressuposta pelo enunciado, é a própria atividade comunicativa em ação.

Poderíamos dizer, portanto, que nas conversações digitais os interlocutores produzem atos enunciativos, uma vez que estes não são atos de fala, pois correspondem à atualização da língua numa situação de interação por meio da escrita, dependente do interlocutor para se desenvolver e não apoiados na fala/oralidade.

A noção de turno poderia, assim, ser substituída pela noção de Ato Enunciativo Digital (AED), uma ação de natureza linguística, verbal e interativa, capaz de produzir efeitos pragmáticos no interlocutor, a ponto de fazê-lo interagir em tempo real, por intermédio de outro AED, acionando assim o processo conversacional digital:

\begin{tabular}{|l}
\hline ;] $\quad$ £ëäño®ö diz: ah to terminandu meu curso \\
Jah - $\quad$ Flamengo, vamos ser campeão *_* diz: ah tah, e do que é mesmo ? :S \\
Inquérito 03
\end{tabular}

Os AEDs têm uma concepção oral, mas o meio é gráfico, o canal de comunicação é escrito, possuindo, portanto, características inerentes aos planos da oralidade (versatilidade, sincronicidade, rapidez) e da escrita (registro formal dos eventos)

Os AEDs, podem ser acionados no momento da conversação digital, independente das escolhas ou AEDs do interlocutor, ainda que mantenha a centração por meio do tópico discursivo, ou seja, apesar de vários AEDs serem lançados simultaneamente, só haverá conversação digital se os interlocutores atenderem aos AEDs de seus parceiros, mediante atos do tipo nuclear ou inserido. 
No exemplo 25, apresentado anteriormente, vários AEDs foram lançados simultaneamente por um dos interlocutores, mas estes só fizeram sentido e o trecho só recebe a característica "conversacional" quando o outro interlocutor responde ao seu pedido inicial, e interage com outros AEDs.

A tabela seguinte ilustra as diferenças entre o turno e o AED:

\begin{tabular}{|l|l|}
\hline TURNO & AED \\
\hline Fala-se um de cada vez & $\begin{array}{l}\text { Não há necessidade de alternância sequencial: } \\
\text { os AEDs podem ser enunciados } \\
\text { simultaneamente, entre os interlocutores. }\end{array}$ \\
\hline $\begin{array}{l}\text { Período de tempo fixo ou não para a consecução } \\
\text { do ato de fala do interlocutor. }\end{array}$ & $\begin{array}{l}\text { Não há tempo fixo nem tamanho pré- } \\
\text { estabelecido para as intervenções. }\end{array}$ \\
\hline Há a alternância no papel de falante e ouvinte. & $\begin{array}{l}\text { Não há a relação falante/ouvinte: os } \\
\text { interlocutores constroem cooperativamente o } \\
\text { texto conversacional, ora como locutor, ora } \\
\text { como alocutário. }\end{array}$ \\
\hline
\end{tabular}

Tabela 7: Diferença entre o turno e o AED

Assim, a conversação prototípica pode ser entendida como uma série de turnos, enquanto a conversação digital seriam vários lançamentos de AEDs, ambos trocados entres interlocutores em tempo real.

Quanto à tipologia, os AEDs se aproximam da classificação de turnos apresentada por Galembeck (1993): há AEDs nucleares, onde os interlocutores desenvolvem os tópicos conversacionais, e os inseridos, que indicam o acompanhamento do fluxo comunicativo na conversa.

Segundo Galembeck (1993), os turnos inseridos podem:

- ter função predominantemente interacional ou;

- contribuir para o desenvolvimento do tópico, incidentalmente.

Na Conversação Digital, há a incidência de ambos os tipos de AEDs, conforme o exemplo seguinte: 
1 - [18:35] GustavoG diz: sabe aquela mina do telefone lá tipow da vendinha?

2 - [18:35] Nece@ilha diz: ãhn

3 - [18:35] GustavoG diz: tiopw ele me ligo. Aheuihauehauh

4 - [18:35] Nece@ilha diz: mintira! Taã zuano.... ahehaueah e ai?

5 - [18:35] GustavoG diz: ah... sei lá... ela ligo pediddo o filme do Cremilllam

6 - [18:36] Nece@ilha diz: evc disse q ?

7 - [18:36] GustavoG diz: to zuando nuam... ... so fôda... q levava na escolla pow...

8 - [18:36] GustavoG diz: a mina nem deu temp deu fala nada ja foi pedidio o filme etalz....

9 - [18:36] GustavoG diz: quando eu fui fala algo mais e talz

10 -[18:36] Nece@ilha diz: fala

11 -[18:36] GustavoG diz: ela nem deu xance, ja foi dando xua

12 -[18:36] GustavoG diz: xau

13 -[18:36] Nece@ilha diz putz sujera..

Inquérito 30

Percebemos aqui que o usuário "Nece@ilha" deixa claras suas marcas de interação e monitoramento do assunto exposto pelo outro, como se pode notar por meio de inserções de interação como nas linhas 2, 4 e 10, evidenciando que está acompanhando o que o outro está expondo, demonstrando a abertura do canal de comunicação, e permitindo, assim, a continuidade da fala do interlocutor. Na linha 6 , verificamos uma contribuição para o fluxo interativo e progressão do tema, "estimulando" o interlocutor a continuar sua exposição, fornecendo novas informações.

Se tomarmos o conceito de AED como referência para as Análise da Conversação Digital, devemos questionar a validade das estratégias de gestão de turno, conforme expostas por Galembeck (1993) uma vez que estas são: "procedimentos, pelos quais ouvinte torna-se falante (troca de falantes) e o falante "segura" o próprio turno (sustentação da fala)".

Como na Conversação Digital não há uma alternância nos papéis de falante e ouvinte, pois ambos os interlocutores interagem simultaneamente no ambiente virtual, não se pode considerar a troca de falantes como um fator relevante para a instauração do processo conversacional, pois não há a necessidade de passagens ou assaltos aos turnos: ambos disparam AEDs, ambos respondem aos AEDs disparados, sem a necessidade de espera pela "vez" de falar. Também não é necessário "sustentar" a vez de fala, uma vez que ambos podem emitir seus AEDs simultaneamente, e serão respondidos, à medida que forem lendo os enunciados disparados.

O papel do AED é promover o contato, chamar o outro à participação. Está a serviço da interação e da interatividade no plano virtual. Quanto à extensão, podemos dizer que os 
AEDs não ultrapassam a marca das três linhas de texto. Em todas as conversações analisadas, a maior parte dos enunciados ficou restrito a uma ou duas linhas.

O papel de regulação da Conversação Digital fica, portanto, a cargo do Tópico discursivo, que vai nortear as interações, sugerindo os caminhos interacionais mais adequados em cada contexto, baseando-se no tema proposto para a discussão.

\subsection{Estabelecimento do tópico discursivo no ambiente digital}

Em sentido geral, entendemos tópico como o assunto sobre o qual a interação está centrada. De acordo com Fávero (1993, p.38), "ele é antes de tudo uma questão de conteúdo, estando na dependência de um processo colaborativo que envolve os participantes do ato interacional".

Podemos afirmar que, no contexto da conversação digital, o tópico discursivo pode ser considerado o núcleo da interação. É por intermédio dele que a conversação digital se estabelece, após o primeiro contato dos interlocutores, geralmente iniciado por um cumprimento. Na maioria das conversações digitais, encontramos aspectos idênticos aos da conversação face a face. Algumas diferenças sutis, porém fundamentais, foram encontradas no ambiente virtual e serão discutidas adiante.

Tomemos por base o inquérito 26, cujo fragmento é apresentado adiante. Esse inquérito possui grande aproximação com os diálogos naturais face a face. Nele, Marco Antonio e Jen Jen conversam durante o período de férias acadêmicas do curso de Direito. $\mathrm{O}$ tipo de relacionamento entre os interlocutores (colegas de curso de Direito - graduação) sugere o tópico central, que desencadeia outros dois tópicos, conforme mostraremos a seguir.

O Tópico é responsável pela manutenção do interesse pelo contato entre os interlocutores. Durante o evento conversacional, os interactantes procuram estabelecer um tópico discursivo, procurando garantir a atenção do outro. Dessa forma, o interlocutor pode colaborar para a manutenção do tópico por meio de suas interações com AEDs.

Nos diálogos analisados, de uma forma geral, e no inquérito 26, particularmente, percebe-se com muita nitidez esse processo de colaboração, quando o interlocutor 
responde à pergunta feita pelo outro, de forma a fazer o possível para centrar os assuntos a serem utilizados como referência da conversa:

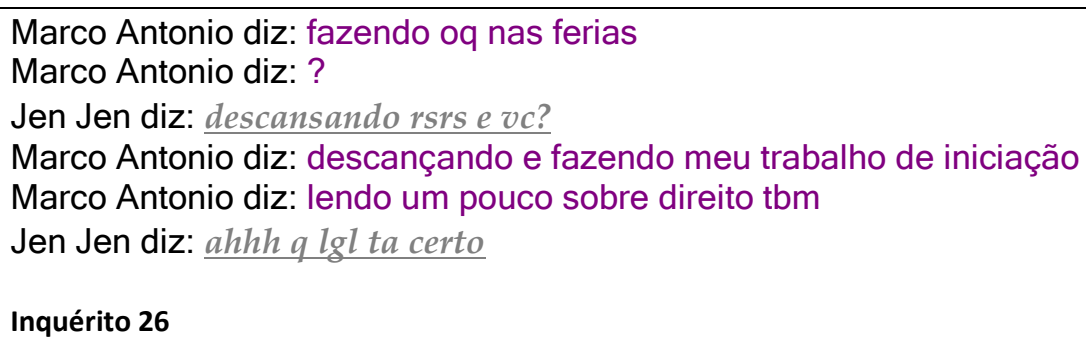

Marco sugere um tópico central (ou supertópico), "Atividades de férias", por meio da pergunta "fazendo oq nas férias", e Jen Jen aceita a proposta, ao responder "descansando rsrs e vc?". Ao retornar a pergunta para Marco, ela promove o desencadeamento dos subtópicos que vêm em seguida.

Pode-se afirmar que uma das características mais evidentes do tópico discursivo é a centração, que é o "falar-se acerca de alguma coisa, implicando a utilização de referentes explícitos ou inferíveis" (FÁVERO:1993, p.40). Segundo Fávero, a centração norteia o tópico de tal forma que, quando se tem uma nova centração, tem-se um novo tópico. A sequência do diálogo entre Marco Antonio e Jen Jen (feminino) nos mostra essa centração sobre um referente não explícito, porém inferível aos dois interlocutores:

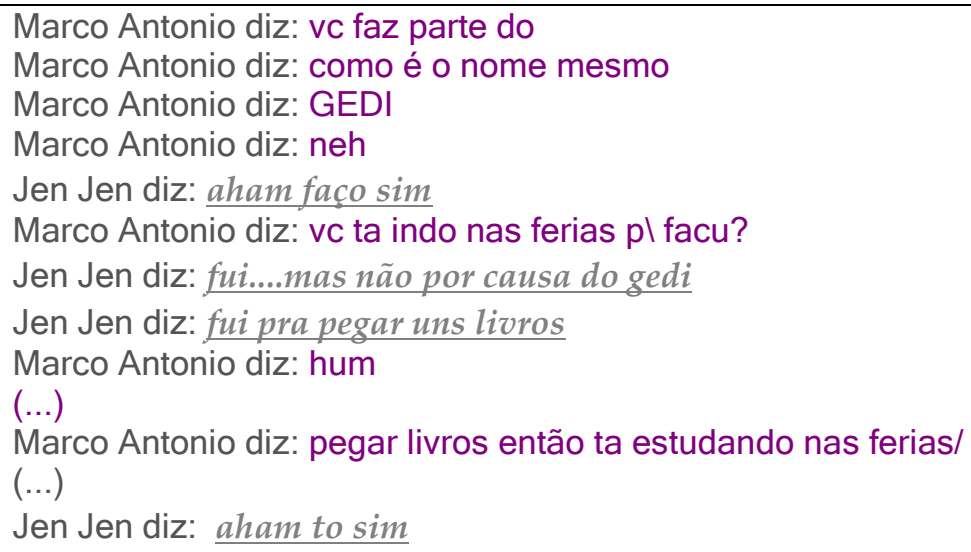

Aqui podemos perceber uma sutil digressão em relação tópico central, que desencadeou no subtópico "Grupo de Estudos", sigla usada por Marco Antonio e inferível por parte da colega, que alega fazer parte do grupo, mas justifica que não foi à faculdade por esse motivo, mas sim para pegar livros. 0 interlocutor, procurando fixar definitivamente 0 
tópico discursivo, volta ao assunto das atividades das férias - a leitura dos livros, por meio do marcador "então", retomando o fluxo temático, o que foi prontamente respondido pela colega.

A análise dos inquéritos permite-nos dizer que a centração é uma característica da conversação face a face extensível à digital, uma vez que a topicalidade organiza o discurso, permitindo a continuidade deste.

Quanto à organicidade, o inquérito 26 , apresentado acima, possui o seguinte quadro tópico:

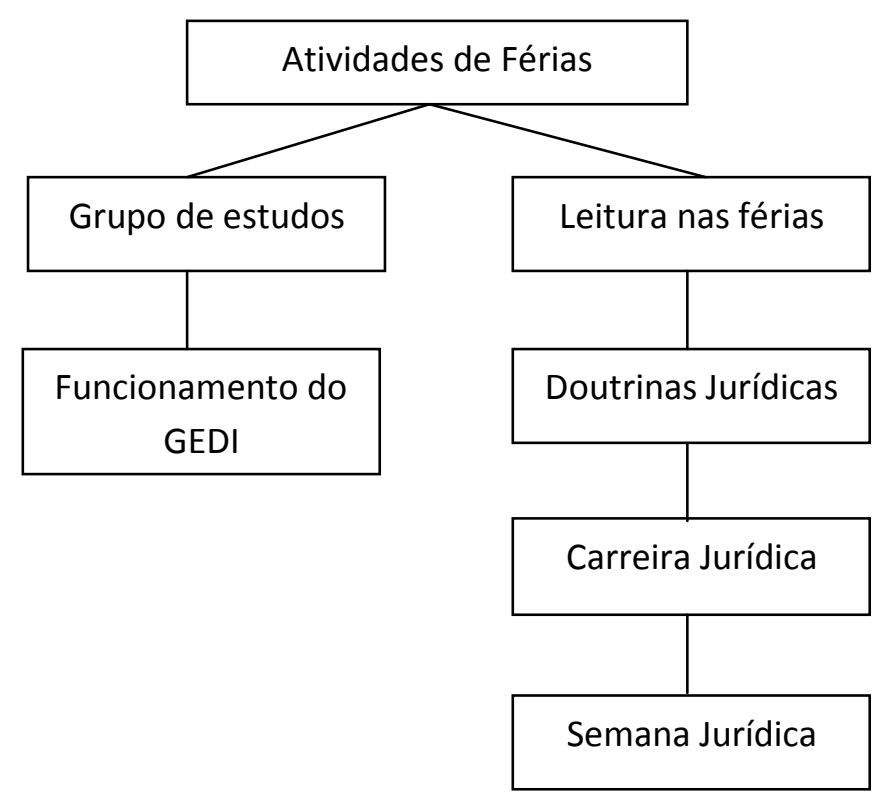

Figura7 . Quadro tópico do Inquérito 26

Esse inquérito se alinha muito bem à noção de interação face a face prototípica, uma vez que o tópico se desenvolve linearmente, ou seja, está centrado numa única linha discursiva ou tópica.

Assim, podemos afirmar que a conversação digital não difere, neste aspecto, da conversação prototípica, uma vez que, na maior parte das vezes, o tópico possui uma articulação de proximidade em relação à linha discursiva, propondo informações novas conforme o desenvolvimento da conversação. A conversação digital apresenta, portanto, uma organização de progressão discursiva, não sendo aleatória ou caótica. 
Uma característica que nos chamou atenção, no entanto, foi o fato de que, em três dos inquéritos sob análise, houve, logo no início das conversações, momentos de "disputa" pragmática entre os interlocutores, na sugestão dos tópicos a serem "promovidos para o evento conversacional em questão". Um exemplo está no inquérito 30 :

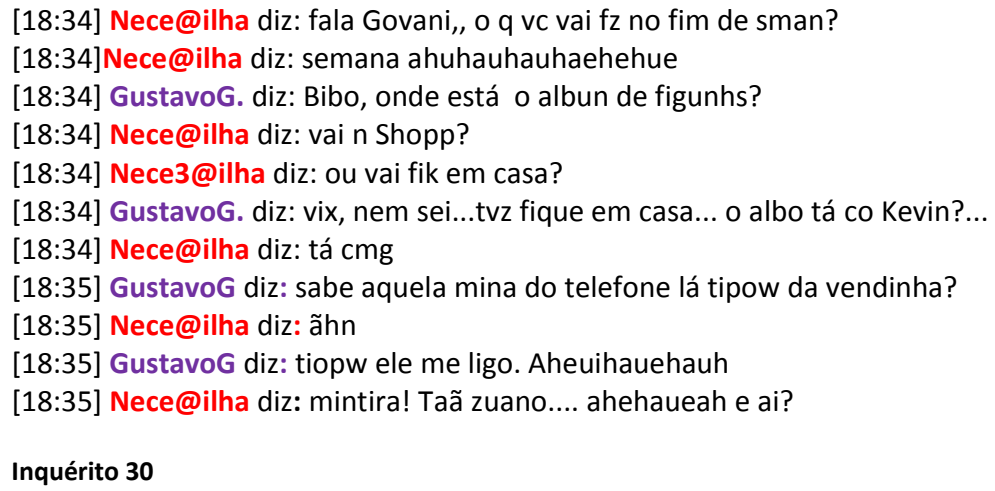

O exemplo acima mostra o momento inicial do diálogo, que não apresenta o esperado cumprimento entre os interlocutores. Pela forma de tratamento usada por um dos interactantes (Bibo) e pela observação do desenvolvimento da conversa, podemos sugerir que os dois participantes possuem um grande laço de afetividade e amizade, motivo pelo qual, talvez, houve a dispensa dos cumprimentos iniciais.

Os interlocutores lançam, cada qual, a sua sugestão de tópico: Nece@ilha quer saber sobre o final de semana, enquanto Gustavo G. deseja informações sobre seu álbum de figurinhas. Percebemos a insistência do primeiro em manter o tópico (vai $n$ Shopp? ou vai fik em casa?). Gustavo G., para não ser descortês, no intuito de manter o evento centrado e promover a interação, responde à pergunta do amigo evasivamente (nem sei... tvz fique em casa...), mas tenta imediatamente retomar o tópico sugerido por ele (o albo tá co Kevin?). Quando Nece@ilha responde que o álbum está com ele, o outro dá-se por satisfeito e sugere um terceiro tópico, que é aceito pelo interlocutor, por meio do AED inserido "ãhn". Nesta situação, os tópicos aparecem "pareados", ou seja, ambos são desenvolvidos ao mesmo tempo pelos interlocutores.

O exemplo seguinte mostra uma situação semelhante: 


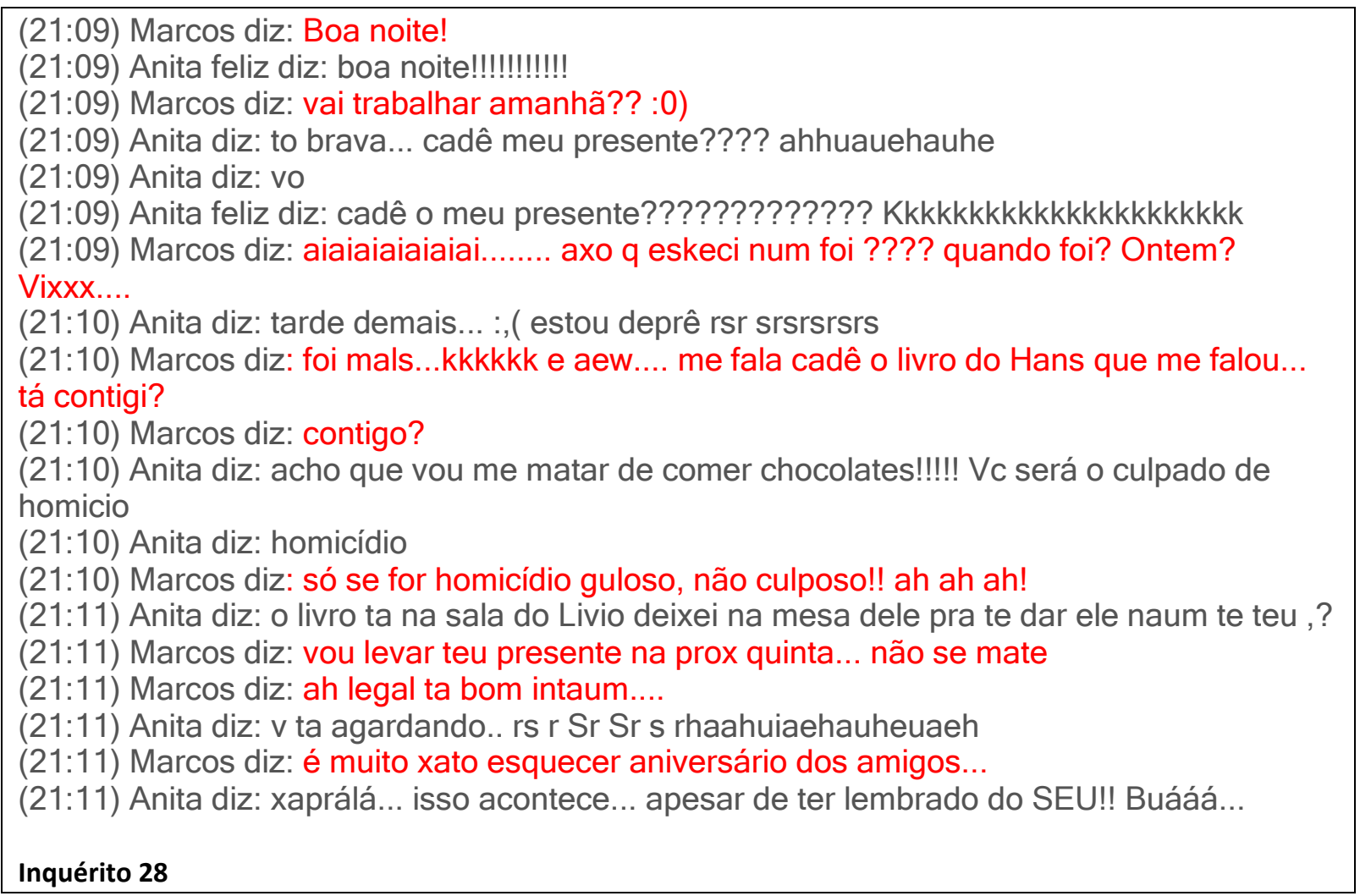

Após o cumprimento inicial, Marcos sugere o tópico "trabalho", enquanto Anita propõe o tópico "aniversário", evidenciando, mais uma vez, uma disputa pelo conteúdo a ser desenvolvido na interação. Marcos responde à solicitação da colega, e responde, mas logo adiante propõe outro tópico, "livro". A colega, inicialmente, não responde à pergunta feita pelo colega (onde estaria o livro prometido), no intuito de manter seu tópico, ou por não ter atentado à pergunta feita, enquanto digitava seu AED. Responde logo abaixo, mas Marco já havia tomado para si o tópico "aniversário", que se manteve daí por diante.

Diante dessas situações, podemos dizer que, na conversação digital, é possível o pareamento de tópicos discursivos, algo que seria improvável na interação face a face. Isso só é possível na conversação digital porque os interlocutores escrevem seus atos enunciativos, o que dá margem a inserções conjuntas, que vão sendo respondidas na medida em que a conversação flui. Esse pareamento de tópicos poderia ser assim representado no quadro tópico: 


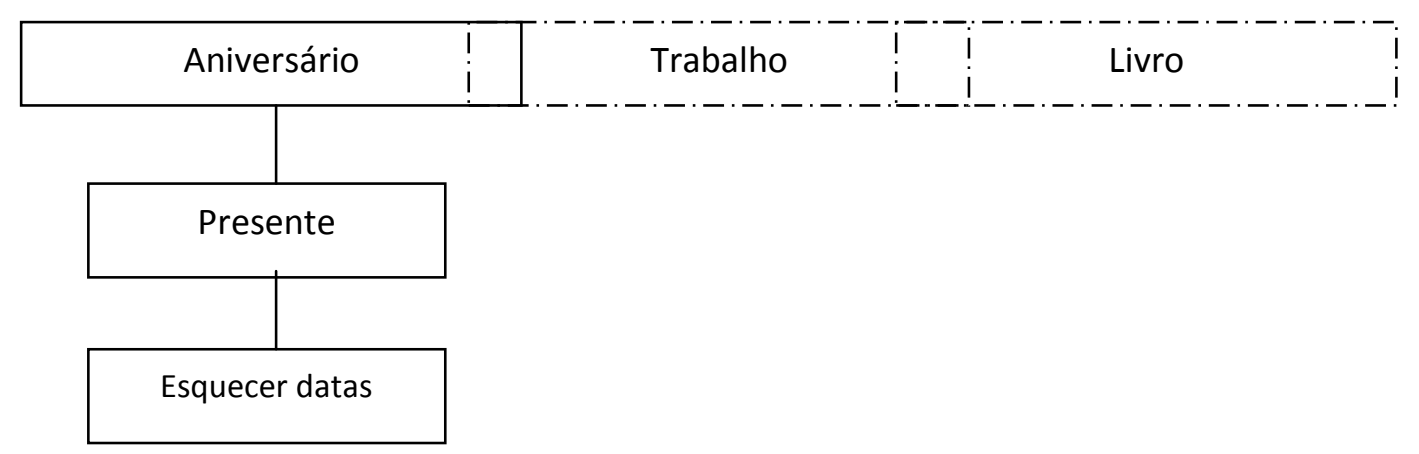

Figura 8. Quadro Tópico (Tópicos Pareados).

Nesse sentido, podemos dizer que várias "sugestões de tópicos" foram dadas por Marcos, mas só um foi eleito para a progressão da conversa. O motivo pelo qual alguns tópicos são eleitos em detrimento de outros pode ser a relevância do tópico e o contexto pragmático em que se desenvolvem. No caso do exemplo acima, a face de ambos estava ameaçada pelo esquecimento de Marcos do aniversário da colega. Ele tenta se esquivar do fato, mas ela insiste no tópico, e acaba "vencendo" o duelo, pois Marcos se retrata dizendo que levará o presente dela (compensação) e acaba afirmando que "é muito xato esquecer aniversário dos amigos", tomando para si o efeito negativo do ato.

\subsection{Marcadores conversacionais na conversação digital}

Os marcadores conversacionais, empregados em posição inicial, distribuem-se nas duas classes já citadas no capítulo anterior: marcadores de valor interacional ou interpessoal (ligados à construção e gestão do ato conversacional) e marcadores de valor ideacional (elementos de coesão entre as partes do texto).

Como a noção de turno não se aplica à Conversação Digital, pode-se dizer que os marcadores iniciais e mediais se fundem, uma vez que os atos de fala podem se subdividir em diversos AEDs, conforme exemplos adiante.

A conversação digital segue, em geral, a tendência da interação face a face: dinâmica, rápida, coerente, porém muitas vezes segmentada. Os AEDs, geralmente, não são extensos, pois a falta de atividade por parte de um dos interactantes pode ser interpretada como descaso ou falta de atenção por parte do outro. Daí a necessidade de os interlocutores "quebrarem" suas sequências de "fala" com acionamentos de "enteres", gerando diversos AEDs que remetem a um mesmo enunciado. 
Sendo assim, a maioria dos AEDs é curta, e quando se precisa prolongar o enunciado, os marcadores ideacionais são utilizados para dar conta dessa necessidade, servindo de aviso ao interlocutor para que espere o outro terminar seu enunciado ou mesmo que preste atenção ao que está sendo dito:

Jah - $\quad$ Flamengo, vamos ser campeão * ${ }^{*}$ diz: auahau, não .. nem tanto, fui ontem a noite, semana passada tb, eu cgg uma a duas vezes por semana, sabiia que eu ia pro Brás ontem ?

danielrodrigues diz: mas tu foi?

Jah - $\quad$ Flamengo, vamos ser campeão * * diz: .. não, maior sacanagem que fizeram, tipow .. marcaram, no dia anterior a viagem, eu .. comprei roupa, fiz escova no cabelo e tals, me troquei, acordei quatro e meia da manhã רר',

Jah - $\quad$ Flamengo, vamos ser campeão * * diz: pq eu fiquei com medo de perder a hora, me troquei e tals, ai quando deu seis e meia, eu liguei pra irmã, uma amiga, mais velha, pra apressar ela sabe?

Jah - $\quad$ Flamengo, vamos ser campeão * * diz: ai ela disse ' ah não ficou sabendo ? cancelaram a viagem, não deu pra te aviisar, pq eu não consegui e tals ', ou seja, maior sacanagem mew ;

Jah - $\quad$ Flamengo, vamos ser campeão *_* diz: ai me eu me troquei a toa e fudo mais, eu ia pagar no dia, ja que a irmã tinha conseguido uma vaga pra mim, mais nem sei quem pagou, como vai, sei lá :S, e não fallaram nada רר' isso!

Jah - $\quad$ Flamengo, vamos ser campeão *_* diz: minha mãe ficou louca com

danielrodrigues diz: É moh sacanagem mesmo...

Inquérito 1

No exemplo acima, o marcador "ai" introduz AEDs em que o locutor dá continuidade ao tópico em andamento - são os sequenciadores tópicos. Esse tipo de marcador, na conversação digital, garante a manutenção do tópico e indica ao interlocutor que o locutor ainda está com um ato enunciativo em andamento. Também é possível constatar o uso de marcadores interacionais de negação "não", usados em início de AEDs. O primeiro, com função negativa, e o segundo, com função eminentemente interacional, de marcação de AED. Como se pode ver, a linha que divide os marcadores ideacionais dos interacionais é muito tênue, pois ambos podem servir às duas funções.

Na passagem a seguir, o marcador "mais" (mas) na terceira linha também funciona como um sequenciador, pois "incentiva" o interlocutor a continuar "teclando" sobre o assunto, promovendo, dessa forma, a manutenção do tópico discursivo: 


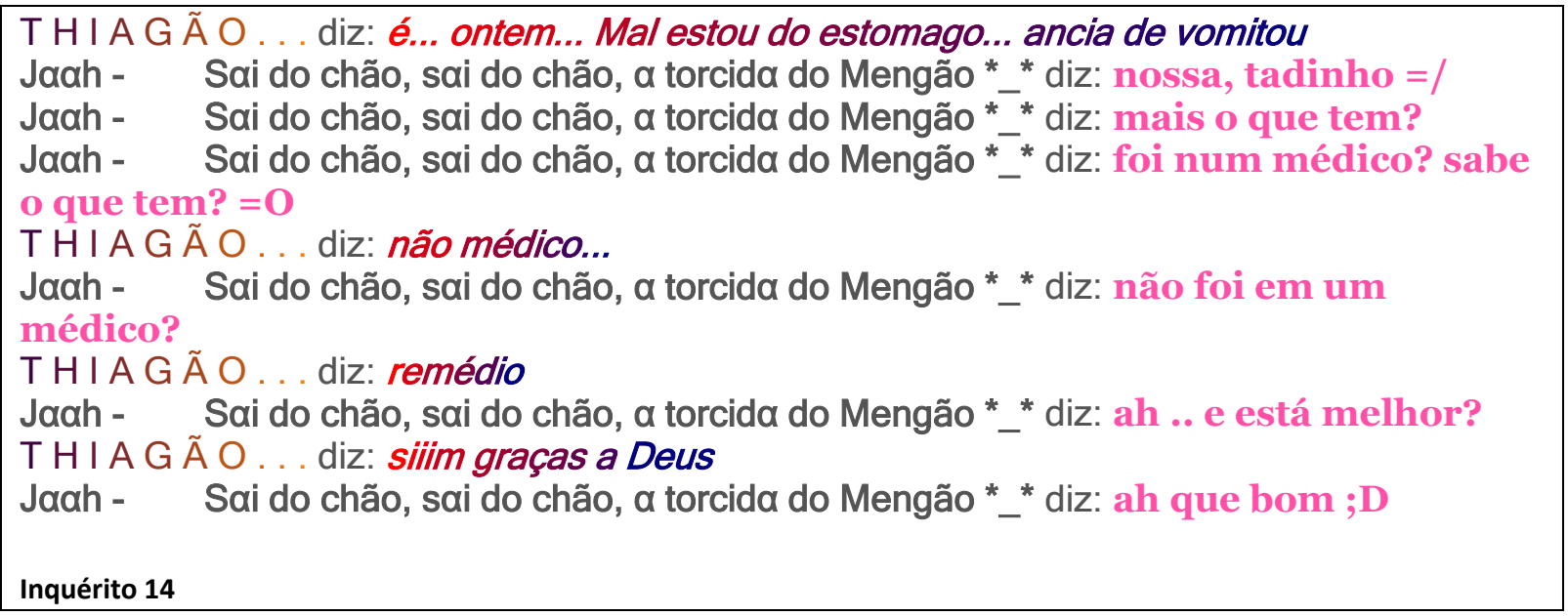

Outros marcadores de posição inicial, que visam a manter o tópico e fazê-lo progredir, podem ser notados no exemplo acima, como "ah", e "e", que também apresentam a função interacional, de envolvimento na interação.

Os marcadores conversacionais de valor ideacional são representados, geralmente, por algumas conjunções e advérbios (e, mas, então, além disso, agora, aliás), que funcionam como elementos de coesão entre partes do texto, dão continuidade ao tópico em andamento ou introduzem um novo tópico; outros marcadores, porém, mesmo não convencionais, - como o caso de "ah" e "ai", podem servir a essa função.

Marcadores de início de novo tópico, ou mesmo que servem para chamar a atenção do outro para o que vai ser dito, também foram encontrados. No exemplo seguinte, os marcadores "então", " escuta" e "olha" funcionam como sinais de chamada de atenção do interlocutor para o que vai ser discutido ou exposto em seguida:

(21:12) Marcos diz: então... escuta.... o almosso do Carlão ta de pe?

(21:12) Anita diz: SSSSSSSSSIIIIIIIIIIIMMMMMMMMMMMMMM! TO LOCA DE VONTADE COMER CHURRASSSSSCOOO... AHAUIEHAUEHUAH

(21:12) Marcos diz: olha o Gustavo vai cmg, tudo bem?

(21:12) Anita diz: no problemmmss babe!!!

Inquérito 28

Neste outro trecho, a expressão "agora vem k" também tem essa função de "chamar a atenção" do outro para o tópico que seguirá. Neste exemplo, percebe-se o alto grau de envolvimento entre os interlocutores; o uso intenso de abreviações e reticências para 
marcar pausas indica a familiaridade com que ambos possuem com este tipo de interação. É interessante também observar o uso de maiúsculas para indicar uma entonação diferenciada, em sentindo ascendente $(\nearrow)$.

[18:36] GustavoG diz: putz pq pegunto tipos do fin de semana? Que zoa? Aaeiaheiaheiha

[18:36] Nece@ilha diz: agora vem k... viu a cara da fssora co keu? Zueraaaaaa.... cololegal.....sinistro rirsososos.... querozoaáááá...aeeeeeeeeee

[18:37] GustavoG diz: ax q vo fik aqui

[18:37] Nece@ilha diz: blz eu Tb vo fik de boa...

[18:37] Nece@ilha diz: entao..... tipo..... viu o lance do keu? Colo na maior KARADEPAU!!AHUAHEUAHEUAH

[18:37] GustavoG diz: doido...

Inquérito 30

Quanto aos marcadores de final de enunciado, encontramos um uso muito próximo da conversação face a face, conforme podemos verificar nos exemplos abaixo. No primeiro caso, o marcador "né" é usado em posição final de EAD, indicando que o locutor quer uma reação do interlocutor. No segundo caso, o composto "num é mesmo?"evidencia um pedido de concordância com o enunciado pelo locutor:

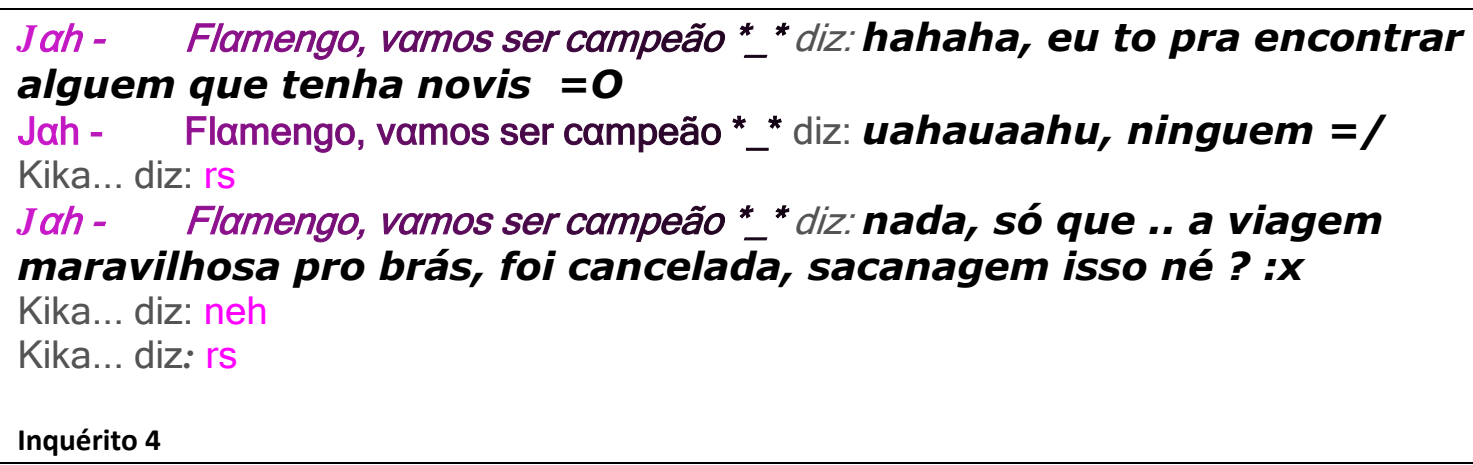

Ao analisar as conversações digitais, como verificamos acima, é muito comum o uso dos marcadores conversacionais no encadeamento textual, o que evidencia o caráter 
dinâmico e dialógico desse tipo de interação. Há outros tipos de marcadores, porém, que são de uso exclusivo das conversações digitais, e geralmente são adaptações de situações da interação face a face.

Os marcadores verbais lexicalizados são representados como na conversação face a face (só que por meio da escrita), enquanto que os prosódicos e não - linguísticos são representados por vários elementos gráficos, como reticências, onomatopéias ou os emoticons (expressões iconográficas que representam emoções humanas ligadas ao humor (como por exemplo: : ). Ou seja, na ausência dos sons e das expressões faciais e corporais, outros recursos são acionados. Elencamos a seguir os marcadores conversacionais de uso exclusivo no ambiente virtual, encontrados nos inquéritos analisados:

\section{a) Reticências (...)}

Encontrado em alguns inquéritos, este é um marcador evidente de representação prosódica, que indica pausas, curtas ou longas. Parece ter uso para hesitações, finalizações e até em progressão de tópico, indicando que um EAD será seguido de outro, que o completará.

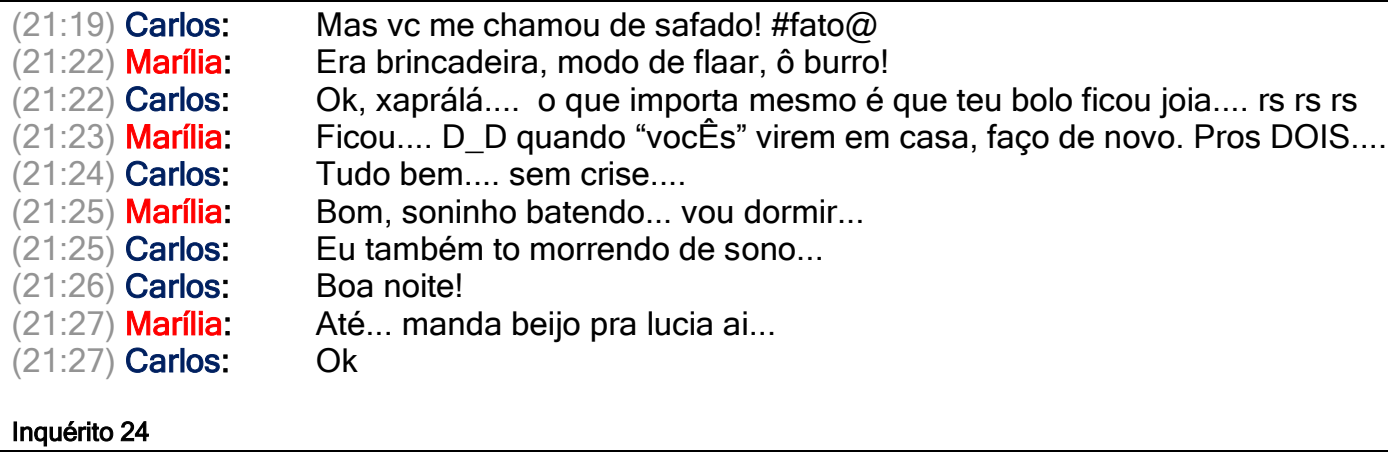

b) Onomatopeias (ae... ae... ae..., uffa, haha, em)

$\mathrm{Na}$ interação face a face, é comum as palavras serem acompanhadas de pequenos gestos ou de tom de voz mais intimista, representado na interação virtual pela expressão lexical do falante com o uso de onomatopeia, por meio da imitação do som e variação da 
voz. Na interação digital, essas imitações se lexicalizam na digitação de diversas maneiras, conforme mostra o exemplo seguinte:

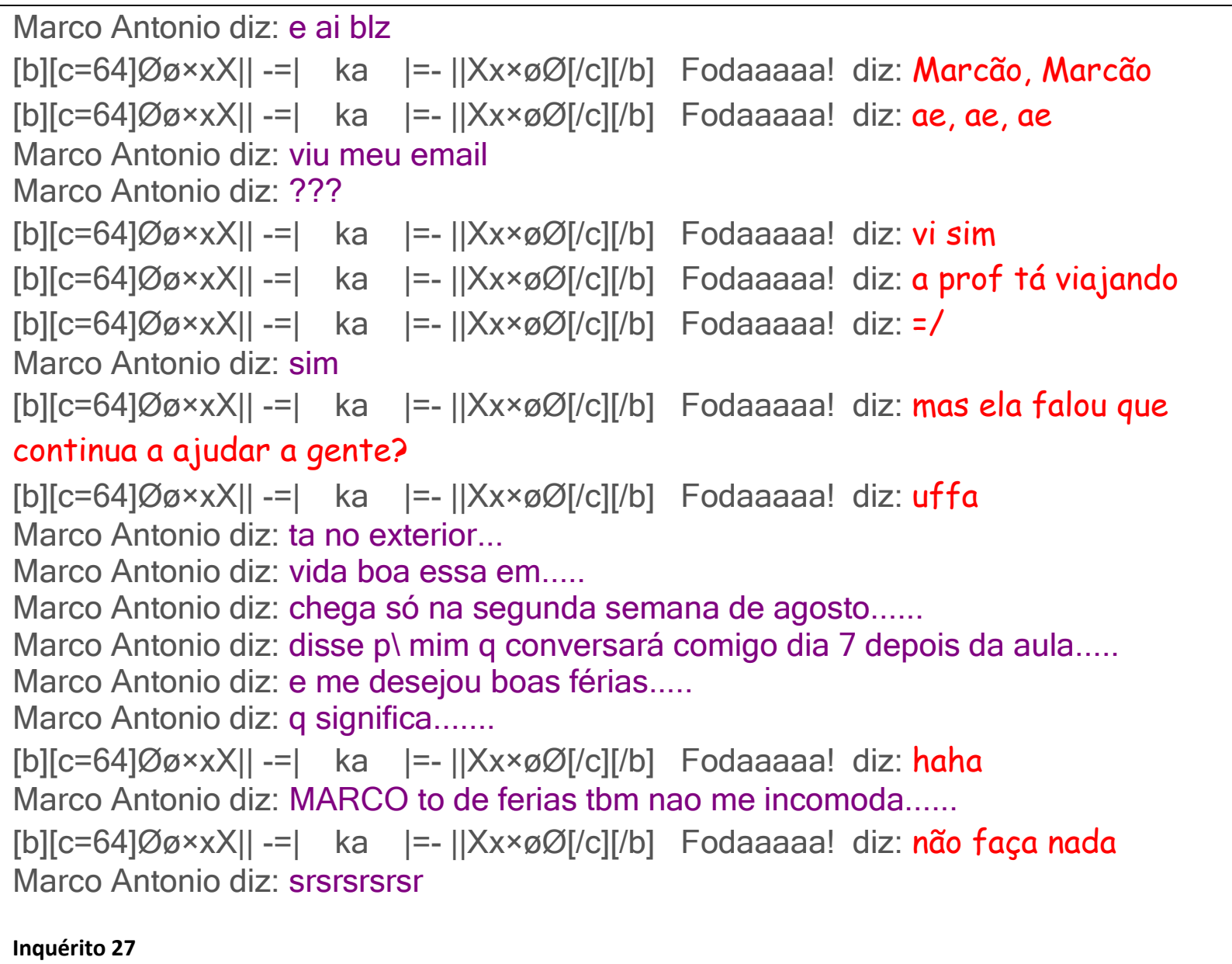

Observa-se, no recorte acima, o uso do marcador verbal "ae, ae, ae" representando uma "entonação de voz", como se o interlocutor estivesse produzindo um caráter mais emotivo no momento da apresentação. Na saudação das interações do tipo face a face, é comum as palavras utilizadas serem acompanhadas de pequenos gestos ou de tom de voz mais intimista, sendo no ambiente virtual representado pela expressão lexical de autoria do locutor com o uso de onomatopeia imitando o som e variação da voz. Outras marcas, como "uffa" "em[hein]", "haha” podem ser também notadas.

\section{c) emoticons}

Os emoticons são figuras iconográficas que representam expressões faciais, e visa a demonstrar emotividade e o humor dos interlocutores no momento da conversação. A expressão é derivada do inglês emotions-ícons, ou ícones de emoção. O MSN Live Messanger 
possui alguns emoticons disponíveis por padrão, conforme se pode ver na imagem reproduzida a seguir:

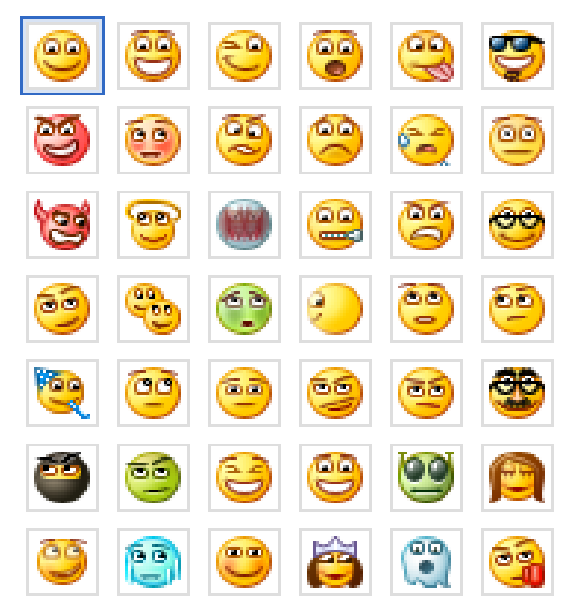

Figura 9. Exemplos de Emoticons

Os usuários, no entanto, podem se valer da digitação associada de letras, números e símbolos para criar outros emoticons. Estes podem representar emoções (alegria, raiva, repulsa/nojo, medo, desejo, espanto), intenções e ações (preguiça, cansaço, beijar, ir à praia, gargalhar, piscar olho), modos de ser e estar (loucura, indecisão), entre outros.

Os emoticons são largamente utilizados na conversação digital. O significado do símbolo =/ do exemplo anterior (Inquérito 27 - oitava linha do exemplo) pode ser resgatado por meio do contexto, e quer dizer um "oh, que tristeza" um tanto quanto irônico. Apresentamos abaixo um quadro com os emoticons mais utilizados em nosso corpus.

\begin{tabular}{|l|l|l|l|}
\hline$:)$ & Sorriso, feliz & $=($ & Triste \\
\hline =D & Sorriso enorme & $=\mid$ & Indeciso, incerto \\
\hline$-\_-$ & Tedioso ou “não gostei” & $: 0)$ & meigo, palhaço \\
\hline$\neg \neg '$ & aff & $\begin{array}{l}=0 \\
:-O\end{array}$ & Nossa! Que coisa! Estou de boca aberta! \\
\hline 8$)$ & & $: S$ & Confuso. \\
\hline$=/$ & Olho grudado, arregalado. & $: @$ & Nervoso, Falando Palavrões \\
\hline ;D & Chateado, triste & $: \mathrm{p}$ & $\begin{array}{l}\text { de língua para fora, expressando } \\
\text { sarcasmo ou debochando }\end{array}$ \\
\hline
\end{tabular}

Tabela 8: Ocorrências de Emoticons no corpus

Alguns emoticons encontrados no inquérito 1:

danielrodrigues diz:q fazes da vida?

Jah - Flamengo, vamos ser campeão *_* diz: .. na net, só 8)

Jah - Flamengo, vamos ser campeão ** diz: e você?

Inquérito 1 
No exemplo apresentado anteriormente, o emoticon 8) reforça o AED do locutor, dizendo que está de olhos "grudados" na internet.

Jah - $\quad$ Flamengo, vamos ser campeão * _ ${ }^{*}$ diz: ai me eu me troquei a toa e tudo mais, eu ia pagar no dia, ja que a irmã tinha conseguido uma vaga pra mim, mais nem sei quem pagou, como vai, sei lá :S, e não falaram nada רי'

Inquérito 1

Aqui a sequência de um :S (confuso) e um $\neg$ ' (aff) indica o estado de humor em que o locutor se encontrava no momento em que emitiu seu AED.

Jah - $\quad$ Flamengo, vamos ser campeão * * $\quad$ diz: tipo, eu to vendo outra excursão já KKK, eu queria ir pro Brás =/

Inquérito 1

Neste caso, o emoticon =/ expressa tristeza e decepção diante do ocorrido.

danielrodrigues diz: tu acredita q meu chefe me ligou agora pra me dar bronca

danielrodrigues diz: já foram falar merda pra ele

danielrodrigues diz: ai q raiva :@

danielrodrigues diz: eu sou um trabalhador tão comportado (a)

Inquérito 1

Neste exemplo, o emoticon :@ indica que o locutor está xingando,com raiva.

Como vimos, usar emoticons provoca uma aproximação entre os interlocutores, demonstrando afetividade, uma aceitação do outro e uma resposta favorável à continuidade do diálogo aproximando-se das características do encontro face a face, no qual podemos identificar, além das palavras, os aspectos não verbais como sorriso, expressão facial, etc.

\section{d) a marcação das interrogativas em um AED isolado (?)}

Muitas vezes, o interlocutor pode considerar o isolamento do sinal de pergunta ( ?) como uma estratégia importante para o fluxo da conversa, chamando a atenção para o questionamento feito ao interlocutor. Trata-se de um marcador não linguístico, encontrado em algumas interações, como no trecho seguinte: 
Marco Antonio diz: viu meu email

Marco Antonio diz: ???

[b][c=64] $\varnothing \times \times x X \|-=\mid$ ka $\mid=-\| X x \times \varnothing \varnothing[/ c][/ b]$ diz: vi sim

$[b][c=64] \varnothing \varnothing \times x X \|=\mid$ ka $\mid=-\| X x \times \varnothing \varnothing[/ c][/ b]$ diz: a prof tá viajando

Inquérito 27

\section{e) CAIXA ALTA (uso de maiúsculas)}

O uso de maiúsculas remete ao tipo de marcadores não linguísticos, prosódicos, indicando entonações diferenciadas, que podem ser consideradas como "animação" do falante (como por exemplo AHUEHUEHUEHHAHEU) ou raiva, nervoso e descortesia (como por exemplo JÁ DISSE QUE NÃO VOU!!!!). A interpretação correta da utilização das maiúsculas no evento comunicacional digital vai depender da análise contextual que, no ambiente virtual, depende do tópico discursivo e da forma como os interlocutores encaminham o diálogo.

No exemplo abaixo, há uma evidente tensão no diálogo, e isso é deixado claro pelo uso da caixa alta (maiúsculas), pela pontuação e pelo uso do emoticon que indica fúria. Os interlocutores estão discutindo, e as intenções pragmáticas de cada um ficam evidentes a cada ato enunciativo lançado:

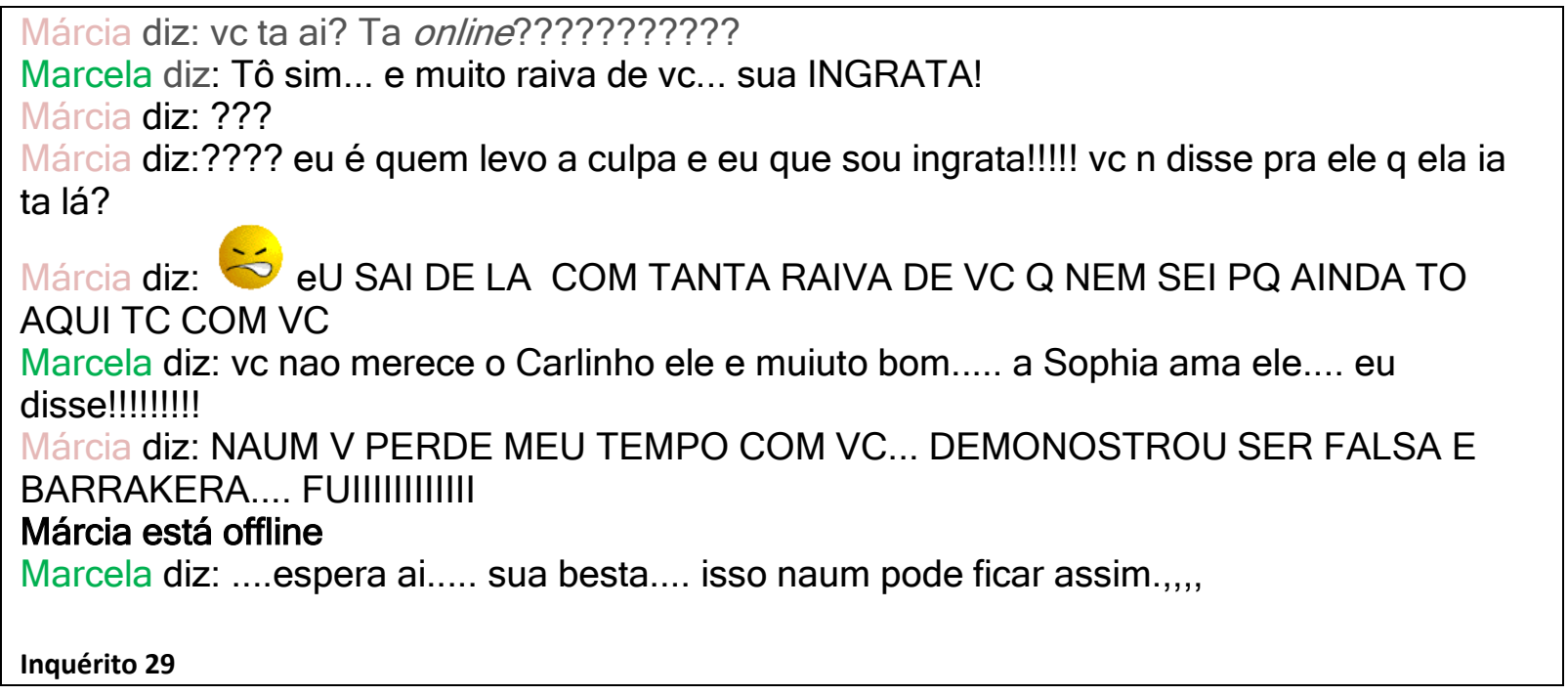

Já no exemplo seguinte, o uso da caixa alta indica, ao contrário do anterior, expressão de alegria, ansiedade, contentamento. A repetição de caracteres e o final representando o riso deixa em relevo esse "estado de ânimo" do locutor: 
(21:12) Marcos diz: então... escuta.... o almosso do Carlão ta de pe?

(21:12) Anita diz: SSSSSSSSSIIIIIIIIIIIMMMMMMMMMMMMMM! TO LOCA DE VONTADE COMER CHURRASSSSSCOOO... AHAUIEHAUEHUAH

(21:12) Marcos diz: olha o Gustavo vai $\mathrm{cmg}$, tudo bem?

(21:12) Anita diz: no problemmmss babe!!!

Inquérito 28

\section{5 Procedimentos de formulação e reformulação na conversação digital}

\subsubsection{Hesitações e Repetições}

Hesitações e repetições fazem parte, conforme verificamos, do âmbito das conversações, e representam momentos de dúvida do falante, diante da escolha de formas adequadas para evidenciar seu enunciado de maneira que o interlocutor compreenda ou forneça um retorno adequado. As situações em que aparecem não são privilégio da conversação face a face, pois encontramos, nos inquéritos das conversações digitais, algumas marcas de hesitação, que nos exemplos abaixo aparecem destacadas:

Jah - $\quad$ Flamengo, vamos ser campeão * * diz: .. hummm, auahaau, entendo

Jah - Flamengo, vamos ser campeão *_* diz: eu acho bonito isso, sabe ? mais eu sou mais na minha Dan, eu ... gosto mais de ficar quietinha, na minha, mais ou menos isso auahau.

Inquérito 1

Jah - Flamengo, vamos ser campeão *_ diz: eu tenho q baixar o skipe ainda, pra falar contigo né ; $D$

JaNiNhA ? diz: é. skype e mara obal

Jah - $\quad$ Flamengo, vamos ser campeão *_* diz: kkkkkkkkk.

JaNiNhA ? diz: eu gosto pq da para conversar bem melhor

humm.....melhor mesmo..

Inquérito 05

No contexto digital, as hesitações são marcadas por reticências, que indicam pausas, e apontam para o momento da formulação do AED por parte do locutor, evidenciando que, devido à agilidade necessária para estabelecer o contato e dar o feedback, não há muito 
tempo de fazer a "lapidação" do enunciado, sendo mais eficaz indicar esse momento de dúvida, diante do que se vai falar em seguida, por meio de pausas.

Em outras palavras, tais marcas evidenciam o caráter urgente com que os atos enunciativos devem ser lançados, muitas vezes não deixando espaço para uma elaboração do texto "escrito", deixando evidentes essas marcas de produção.

Além das reticências, não encontramos outros sinais que indicam a hesitação no contexto digital. Não parece haver usos de prolongamentos hesitativos, do tipo prosódicos ou indicadores de alongamentos vocálicos, assim como na oralidade, mesmo representados na escrita. Esse tipo de hesitação não contribuiria para a rapidez do fluxo informativo, ponto crucial para a conversação digital existir.

Notamos também que pode haver a possibilidade de o locutor ter, como objetivo interacional e pragmático, a intenção de "criar" uma situação de hesitação, com vistas a deixar o interlocutor ciente de sua posição diante de um AED anteriormente emitido.

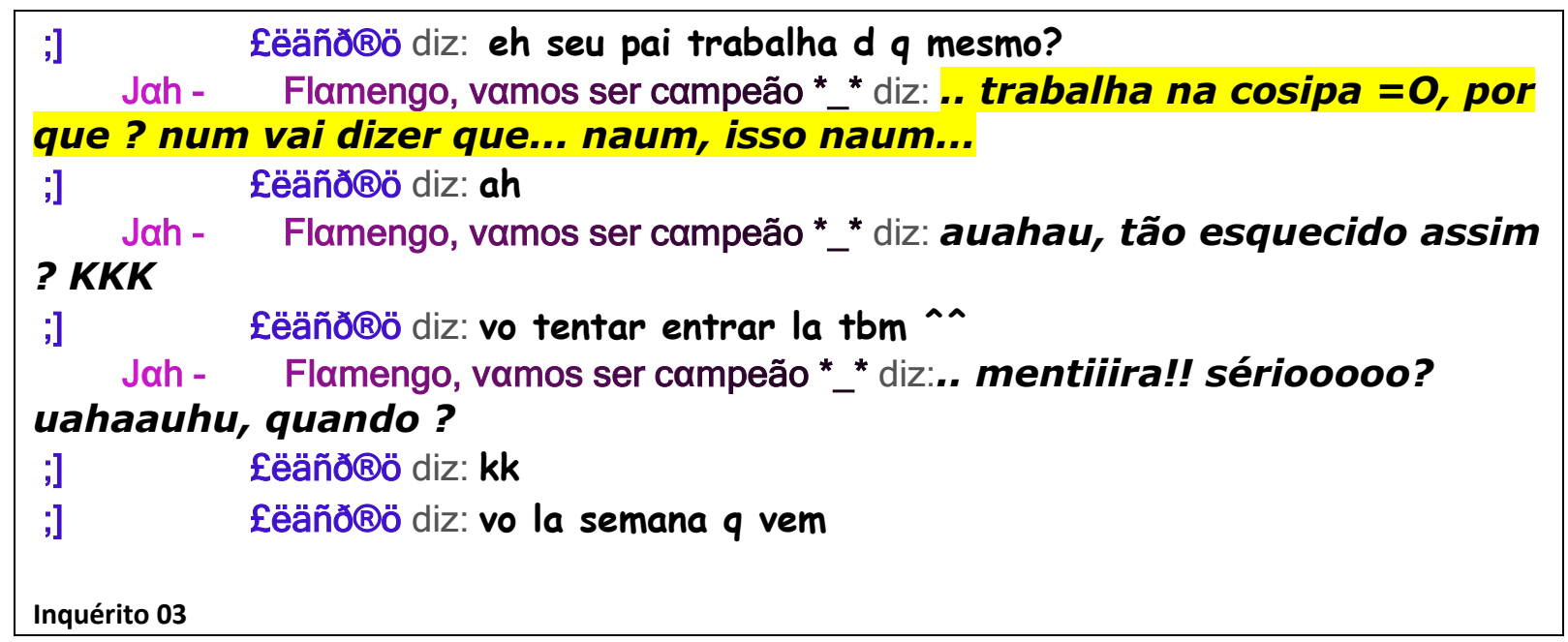

No exemplo acima, a marca de hesitação parece ter sido usada propositalmente, para deixar o interlocutor "sem graça" ao esquecer o local de trabalho do pai da colega com quem estava conversando. Notamos aqui, também, o uso da repetição, juntamente com o processo hesitativo. Apesar de ser esse recurso possível, assim como na conversação face a face, o mais comum é que seja "acidental" ou "não planejado", contribuindo para o fluxo conversacional e desenvolvimento do tópico discursivo: 
Jah - Flamengo, vamos ser campeão *_* diz: .. não, maior sacanagem que fizeram, tipow .. marcaram, no dia anterior a viagem, eu .. comprei roupa, fiz escova no cabelo e tals, me troquei, acordei quatro e meia da manhã רי',

Inquérito 1

Quanto às repetições, estas não se mostraram produtivas nesse contexto e, portanto, não ocorrem com frequência na conversação digital, sendo mais evidente nos reforços de negação. Marcuschi (1996, p. 107) conceitua repetição como "a produção de segmentos discursivos idênticos ou semelhantes duas ou mais vezes no âmbito de um mesmo evento comunicativo". A matriz (M) é a primeira entrada do segmento que opera como base ou modelo para a projeção de outro segmento construído à sua semelhança ou identidade, chamado de repetição (R). O exemplo seguinte mostra a repetição da negação, utilizando-se de uma estrutura diferente da primeira:

danielrodrigues diz: e vc te ccg mto?

Jah - Flamengo, vamos ser campeão * * diz: auahau, não .. nem tanto, fui ontem a noite, semana passada tb, eu cgg uma a duas vezes por semana, sabilia que eu ia pro Brás ontem?

Inquérito 01

Sendo assim, o primeiro "não" serve de matriz para a expressão seguinte, "nem tanto", e funcionam como elemento de ênfase no processo pragmático. O exemplo seguinte evidencia esse aspecto, ao repetir em diversos AEDs seguidos a palavra "nunca". Também a hesitação por repetição, com a dupla negação (não/nenhuma):

Ja*cia*ra diz: novis ?

Jah - Flamengo, vamos ser campeão * * diz: aham, não .. nenhuma e aii ? ;D aauahaauh.

Jah - $\quad$ Flamengo, vamos ser campeão *_ * diz: nunca tenho novis auahau $=\boldsymbol{O}$

Jah - $\quad$ Flamengo, vamos ser campeão *_* diz: nunca ninguem tem né? KKK

Inquérito 08

\subsubsection{Atividade de Reformulação: correção}

Segundo Fávero, Andrade \& Aquino (1999, p.71), "as correções apresentam a função geral de caráter interacional, no que diz respeito à busca de cooperação, intercompreensão, e o estabelecimento de relações que envolvem os interlocutores". 
Na conversação digital, a ausência da voz e o deslocamento do texto escrito para o plano da oralidade, estabelecendo relação do tipo dialógica, é um fator determinante para que a correção apareça. Não há reparos propriamente ditos, visto que esta é uma correção de uma infração conversacional, e, no plano virtual, não há gestão de turnos, não havendo a necessidade de se realizar esse procedimento.

Os casos de reformulação encontrados nas conversações digitais ficaram restritos às autocorreções propriamente ditas, que representam a tentativa de solucionar problemas retrospectivos de compreensão do enunciado, além de tentar salvar a face de situações ameaçadoras da imagem pública:

danielrodrigues diz: Tá bom, num to te obigando a vc cair no quebra, só estou falando q vc irá por si mesma...

danielrodrigues diz: *obrigando

Jah - $\quad$ Flamengo, vamos ser campeão *_* diz: uahaau, eu sei querido, não se preocupe ;D

Jah - Flamengo, vamos ser campeão *_ diz: auahauahau, tá tudo bem KKK Inquérito 1

Os casos de autocorreções, na verdade, são realizadas pelos participantes com a finalidade de antecipar-se à crítica, de maneira que, além de ser plenamente compreendido, possa também evitar que o interlocutor o corrija ou solicite correções. Nos inquéritos analisados, ficaram restritos a correções vocabulares, com falhas cometidas a partir de erros de digitação. Esses erros são comuns, e são decorrentes da percepção ou impressão que o locutor tem de que está em presença ou sob o olhar do outro, tendo que digitar rapidamente para lançar seus AEDs.

Um aspecto importante e delimitador para a autocorreção, é que, segundo Fávero, Andrade \& Aquino (1999), esta comumente ocorre em um mesmo turno, e geralmente na mesma frase, porque o falante tem pressa em corrigir-se, já que pode perder o turno e a oportunidade de reformular o enunciado. (op.cit, p.66). No caso das conversações digitais, a ausência dos turnos permite que o locutor faça suas autocorreções em outro AED, uma vez que, se notar o "erro" no momento da formulação do ato enunciativo, corrige antes de o emitir. Tendo isso em vista, é notório que os casos de autocorreção encontrados foram emitidos em AEDs isolados, conforme observamos nos exemplos: 


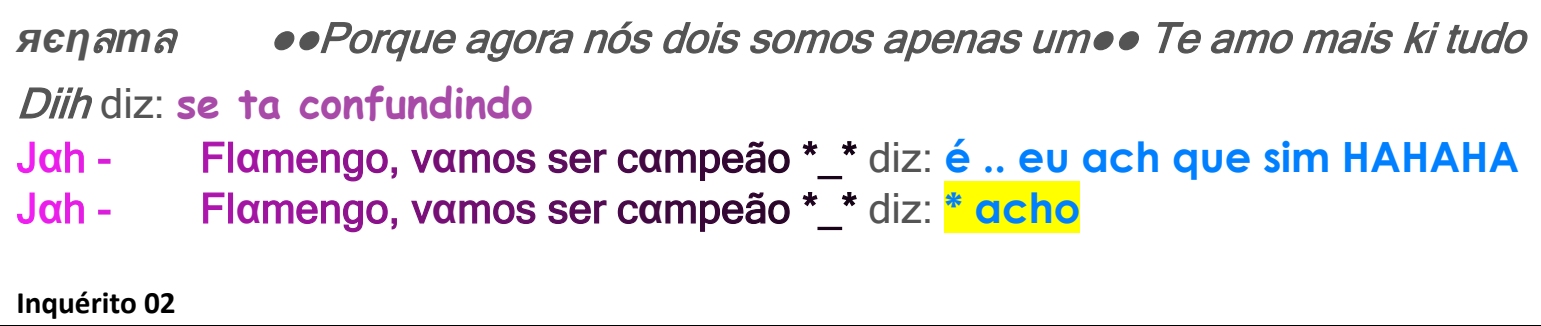

Notamos a preocupação do locutor em corrigir palavras de forte representatividade para o conteúdo informacional do enunciado (Santos, Corinthians), em detrimento da abreviação "mt",ou muito, posto que esta não representava importância para o avanço do tópico e estabelecimento do assunto/conteúdo em pauta.

A característica evidente da correção na conversação digital é o uso de um asterisco, indicando a correção, conforme podemos ver nos exemplos apresentados. Há casos, porém, em que a autocorreção é feita sem o uso deste procedimento:

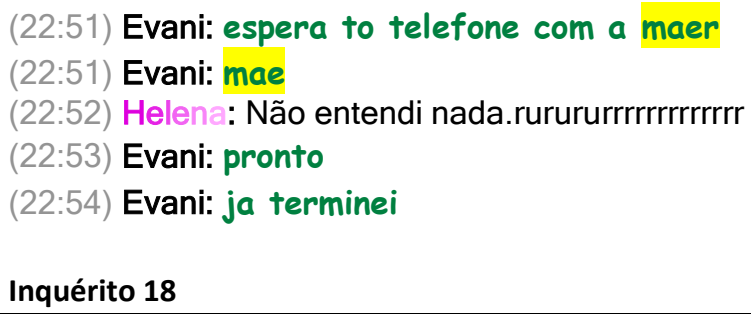

É importante ressaltar que não há preocupação, por parte dos interlocutores, em se fazer correções sintáticas ou gramaticais, estando a preocupação voltada apenas para que as "palavras chave" dos enunciados sejam compreendidas. Também é notório que, apesar de as falhas ortográficas muitas vezes não prejudicarem a compreensão do enunciado como um 
todo, a correção é feita, pois desvios ortográficos são estigmatizados socialmente, e podem inclusive denunciar falta de cultura letrada do locutor.

Assim, pode-se dizer que os interlocutores procuram se envolver no processo interativo, corrigindo seus AEDs de maneira que garantam, além da compreensão do que dizem, também a preservação de suas faces positivas. 


\section{CAPÍTULO IV \\ A Cortesia Verbal na comunicação humana}

"A polidez faz o homem parecer por fora o que deveria ser por dentro" (Jean de La Bruyère)

\subsection{Breve retrospectiva histórica sobre a Cortesia ${ }^{3}$}

O conceito de cortesia está intimamente ligado à história do próprio homem e da organização social, que estabelece identidades sociais e condutas verbais a serem utilizadas durante os processos interacionais.

De acordo com o dicionário Aurélio (FEREIRA:1975), Cortesia significa "maneiras de homem da corte", "delicadeza, amabilidade, urbanidade", ligando-se em primeira instância a um modo "fino" de expressão, apurado, apontando para o domínio dos rituais próprios da hierarquização social. O homem civilizado é cortês, educado, refinado, entende o próximo e procura, sempre que possível, demonstrar deferência e cuidado com seus interlocutores.

Rodriguez \& Lara (2008) indicam que, dentro da interação verbal, o princípio discursivo básico é o da cortesia, que se manifesta por meio da amabilidade, em fazer com que o interlocutor se sinta prestigiado e valorizado durante o processo discursivo. Isso significa que há um compromisso velado, em primeira instância, em constituir uma imagem social positiva, por meio de comportamentos aceitos social e interlocutivamente. (p.15)

\footnotetext{
${ }^{3}$ Concordamos com VILLAÇA \& BENTES (2008), quando afirmam que: "a cortesia, bem como a polidez, dentre outros fenômenos, são forjados em meio às práticas sociais, isto é, são fenômenos constitutivamente culturais. Estão, pois, vinculados a determinadas formas de representação da estrutura e do funcionamento dos regimes simbólicos da interação social". Sendo assim, optamos aqui por utilizar o termo "cortesia", tal como fizeram os pesquisadores do projeto NURC/SP na obra Cortesia verbal, nono volume da série Projetos Paralelos.
} 
“... além de propiciar a construção de uma imagem de refinamento para o locutor, conferindo-Ihe uma determinada posição de superioridade sociocultural (a posição de uma pessoa cortês, distinta), a cortesia linguística pode também ser uma espécie de 'exibição de afeto e/ou gentileza' por parte do locutor que (...)procura mostrar respeito por uma suposta delicadeza emocional do interlocutor e, ao mesmo tempo, o seu próprio conhecimento, sensibilidade, refinamento" (VILLAÇA\&BENTES, 2008, p.20)

Sendo assim, a cortesia é um elemento que nos remete diretamente ao conceito de sociedade, e dela provém. Fernandez (2001), ao tratar do tema "amor e cortesia na literatura medieval", afirma que o termo "cortezia" é derivado de court (corte), e designava o conjunto de qualidades do nobre e o modo de viver da aristocracia que começou a se formar a partir do século XII.

Incentivados pela lírica provençal, o conceito atinge regiões europeias ao longo dos séculos XII e XIII, a começar pela região Norte da França, na qual a cortesia provençal foi traduzida por "courtoisie", até a Península Ibérica, onde o termo aparece na obra do poeta aragonês Martin Moya.

Segundo o autor, a noção de "cortezia", que foi consagrada pela literatura provençal, representava um fato social, uma vez que as regras da cavalaria e a vida aristocrática suscitavam valores como pudor, respeito e boas maneiras de tratamento.

\footnotetext{
A cortesia não é apenas o código de etiqueta próprio da vivência refinada da corte, mas uma verdadeira moral idealizada da elite feudal. "En los versos trovadorescos", diz Martín de Riquer, "la cortezia es una noción muy concreta, aunque muy amplia, pues supone la perfección moral y social del hombre del feudalismo: lealtad, generosidad, valentía, buena educación, trato elegante, aficción a juegos y placeres refinados, etc" (1975, p. 85).
}

Assim sendo, é notório que a noção de cortesia representava um ideal de moralidade, de valores considerados elevados para a sociedade da época, ideias que eram representados na lírica e nas histórias contadas.

Quem não apresentava essas qualidades, valores e hábitos corteses, era pejorativamente chamado de "vilão", "da vila", que contrapunha ao estilo aristocrático, 
antítese da rusticidade, vilania. Essa segregação social do ideal de cortesia na literatura da época pode ser percebida nos versos de Guilhem IX da Aquitânia,

\author{
Obediensa deu portar \\ a maintas gens qui vol amar; \\ e cove li que sapcha far \\ faitz avinens \\ e que.s gart en cort de parlar \\ vilanamens-
}

Segundo Villaça \& Bentes (2008, p.21), "uma observação mais detida (...) nos diz que o fenômeno da cortesia nasce como um estilo da aristocracia, da elite feudal, atribuindo a seus membros determinadas qualidades (lealdade, generosidade, valentia, boa educação, trato elegante, afiç̧ão por jogos e prazeres refinados)."

A partir do século XIV, a cortesia se consolida com a passagem do feudalismo para o absolutismo. Os pequenos feudos, desprotegidos, cediam lugar a grandes feudos e, posteriormente aos reinos, com um único senhor feudal, o "rei", que garantia melhores meios de sobrevivência e proteção, exercendo domínio sobre todos, paulatinamente. (LEITE: 2008)

Os cavaleiros feudais viram, então, a necessidade de se tornarem homens cortesãos, capazes de conviverem social e pacificamente na corte do rei, ajustando-se para refrear seus instintos até então valorizados: a lei da espada que prevalecia nos conflitos e guerras constantes. (LEITE:2008)

Segundo LEITE (2008, p.52), “... [cortesia] foi o padrão das maneiras, a convenção do comportamento e polimento de conduta social (....), [exigidos] pela necessidade de convivência pacífica, ou seja, pela harmonização da sociedade.

Segundo a autora, palavras como "civilidade" e "polidez" perpassam a noção de cortesia entre os séculos XVI e XVIII, culminando no século XIX na assimilação coletiva das regras de boa convivência social, a "civilização".

Assim sendo, o conceito de cortesia está intimamente ligado às condutas construídas socialmente, representando práticas aceitáveis ou não aceitáveis em determinados momentos históricos. 


\subsection{Buscando o conceito de Cortesia Verbal}

Vivemos num mundo tomado pelas interações, e podemos dizer que a vida em sociedade demanda interações constantes, de maneira incessante. Essas interações precisam ser regulamentadas, ou regidas por normas de convivência, e essas normas refletem inevitavelmente na linguagem. Nessas interações, algumas convenções são criadas, para que se possa manter um mínimo aceitável de civilidade, por meio de padrões universalmente aceitos como bons ou adequados.

Marcuschi (2001) cita o fato de sermos eminentemente interativos, talvez por uma necessidade de sobrevivência. Segundo ele, todo encontro é interativo, porém nem sempre essas interações são bem sucedidas, pois isso depende de um trabalho colaborativo, por meio de atitudes cooperativas. Dessas atitudes fazem parte a construção de uma imagem positiva de si e do interlocutor, e o respeito pelas imagens criadas: ai entra em jogo a cortesia verbal.

É interessante notar que o desenvolvimento dos recentes estudos linguísticos na área de pragmática linguística traz em seu bojo o interesse pelo funcionamento da cortesia nas interações verbais, conforme notou Orecchioni:

“... hoje se admite que é impossível descrever de modo eficaz o que se passa nas trocas comunicativas sem considerar algumas princípios da polidez, na medida em que tais princípios exercem pressões muito fortes sobre a produção dos enunciados..." (ORECCHIONI:2006, p.76)

Segundo Eelen (2001), os diversos conceitos de Cortesia nos apontam para fenômenos que vão além dos elementos linguísticos, ou seja, apresenta-se também em comportamentos não verbais ou não linguísticos.

\footnotetext{
"A maioria das pessoas vai estar familiarizado com exemplos de polidez como segurar a porta aberta para alguém, cumprimentar alguém com um aceno de mão ou um aceno de cabeça e assim por diante". (Introdução - p.iv) ${ }^{4}$
}

4 "Most people will be familiar with examples of politeness such as holding the door open for someone, greet someone with a wave of the hand or a nod and so on". (Introduction - p.iv) 
Concordamos com o autor, uma vez que a cortesia não é exclusividade da linguagem verbal. Ela pode se manifestar em diversos tipos de comportamentos, tais como retornar um aceno, aproximação corporal, tipo de olhar, entre outros. Nesse sentido, é possível, também, percebermos a falta de cortesia em algumas situações, como por exemplo, falar alto em uma biblioteca ou igreja, fixar o olhar em alguém desconhecido por muito tempo, espiar pessoas pela janela, entre outras situações.

Eelen afirma que uma das características mais interessantes da cortesia é a análise das relações entre linguagem e realidade social, associação que é feita naturalmente desde as origens da civilização, conforme vimos anteriormente. Por meio da linguagem e dos usos verbais, podemos compreender e interpretar a sociedade, as relações sociais e os usuários das línguas.

É por meio da linguagem que o homem demonstra sua civilidade, sua educação e sua forma de ser e agir. A forma como fala e conduz suas interações verbais caracterizam-no enquanto ser social, membro de uma comunidade de fala e costumes, que respeita e quer ser respeitado, passando uma imagem "positiva" para todos.

É importante ressaltar o esforço elaborado nas interações, onde os interlocutores procuram manter sua imagem preservada, salvaguardada, desejando ainda que suas intervenções sejam valorizadas e respeitadas. Para tal, os interlocutores se utilizam de recursos linguísticos e extralinguísticos que procuram equalizar as interações, de modo que se evitem as imposições à sua fala e à sua pessoa. Essa é a premissa da cortesia verbal.

\footnotetext{
“A noção de polidez é aqui entendida em sentido amplo, recobrindo todos os aspectos do discurso que são regidos por regras, cuja função é preservar o caráter harmonioso da relação interpessoal." (KERBRAT-ORECCHIONI:2006, p.77)
}

Tomamos, pois, a cortesia como o processo pelo qual os interlocutores conduzem ações reguladoras de comportamento verbal e não verbal, no sentido de criar uma imagem socialmente aceita e positiva. Assim sendo, a cortesia representa formas de comportamentos humanos universais.

Embora existam muitas diferenças interculturais concernentes à manifestação formal, as normas de cortesia verbal regulam o comportamento do homem na sociedade. 
Durante essas manifestações ou interações verbais, o risco de conflitos é inevitável, e recorre-se então a formas de cortesia para sustentar e harmonizar essas relações e evitar rupturas e ameaças recíprocas.

Assim, a cortesia é um procedimento a serviço da interação humana, à disposição dos interlocutores para fins comunicacionais, sendo passível de análises em que se pode observar sua utilização ou mesmo sua ausência, em situações de conflito interacional.

\subsection{Princípio da Cooperação: Grice (1982)}

A interação verbal não é caótica, desconectada ou sem elementos de regulação. As interações tendem a seguir certos rituais e procedimentos que permitem a racionalidade e a organização das conversas cotidianas.

A teoria do Princípio de Cooperação (ou Princípio Cooperativo), elaborada por Grice (1982), postula que, durante a interação, as pessoas produzem esforços cooperativos para tornarem a comunicação efetiva. Durante 0 processo interacional, alguns atos conversacionais seriam evitados ou eliminados por não serem adequados a uma determinada situação contextual. (Grice:1982, p. 86)

Grice estabelece um princípio geral para os interlocutores, que seria fazer "sua contribuição conversacional tal como é requerida, no momento em que ocorre, pelo propósito ou direção do intercâmbio conversacional em que você está engajado" (op. cit. p. 86).

Para que os objetivos comunicativos sejam alcançados, o auto propõe quatro máximas, explicitadas abaixo:

\section{Máxima da Quantidade}

$\rightarrow$ Faça com que sua contribuição seja tão informativa quanto requerido.

$\rightarrow$ Não faça sua contribuição mais informativa do que é requerido.

\section{Máxima da Qualidade}

$\rightarrow$ Não diga o que você acredita ser falso.

$\rightarrow$ Não diga senão aquilo para que você possa fornecer evidência adequada.

\section{Máxima da Relação}

$\rightarrow$ Seja relevante 


\section{Máxima do Modo}

$\rightarrow$ Seja claro

$\rightarrow$ Evite obscuridade de expressão

$\rightarrow$ Evite ambiguidade

$\rightarrow$ Seja breve

$\rightarrow$ Seja ordenado

As máximas citadas são, na visão do autor, necessárias para que a comunicação seja bem sucedida, tendo como foco indicar aos interlocutores as suas expectativas durante a interação. Uma observação atenta, porém, indica que, em situações de comunicação rotineiras, do cotidiano, essas máximas são violadas a todo o instante, gerando as implicaturas conversacionais.

O autor afirma que as implicaturas não são erros de comunicação, falta de conhecimento ou ingenuidade do locutor, mas são produzidas racionalmente. Ao violar uma máxima, ele demonstra sua intencionalidade, e o interlocutor, por inferência e pelo contexto, percebe e compreende o motivo da violação da máxima, recuperando o que o locutor quis realmente dizer.

É o que acontece em:

A) Vamos ao cinema?

B) Só se for no dia do pagamento.

Por inferência, $A$ entende que $B$ faz uma negação, utilizando a indiretividade para dizer que "está sem dinheiro".

Assim, para Grice, quando se emite um ato de fala, a compreensão deste é resultado de uma leitura, por parte do interlocutor, do contexto e das condições de produção deste, avaliando-se a intencionalidade, levando-se em conta o que foi dito e em que situação.

\subsection{A abordagem de Lakoff (1973)}

Seguindo a linha proposta inicialmente por Grice, e realizando uma releitura sobre suas máximas conversacionais, Lakoff (1973) propõe que exista uma diferença entre um comportamento grosseiro, rude, e um comportamento polido, cortês. Partindo desse conceito, Lakoff propõe uma série de regras de cortesia, "destinadas a limitar ao máximo o risco potencial de conflito em qualquer interação verbal" (SILVA:2008, p.171). Por meio de 
sua teoria, a autora procura explicar que as máximas propostas por Grice nem sempre são respeitadas, mantendo a interação em qualquer situação.

Lakoff propõe a existência de duas regras pragmáticas que regulam a interação:
a) seja claro e;
b) seja cortês.

Apesar disso, a autora destaca a importância da cortesia, uma vez que é mais importante evitar o conflito do que alcançar a clareza.

\begin{abstract}
"A cortesia se sobrepõe: é considerado mais importante evitar conflito do que alcançar clareza. Isso faz sentido uma vez que na maioria das conversações informais a comunicação de ideias é secundária à reafirmação e reforço das relações" (p. 297-298) ${ }^{5}$
\end{abstract}

A noção de cortesia, para a autora, relaciona-se à necessidade constante de se evitarem conflitos na interação. Para tanto, Lakoff idealiza três submáximas de cortesia, resumidas a seguir:

a) não imponha (usada em situações formais/impessoais);

b) dê opções (usada em situações informais);

c) faça o ouvinte se sentir bem (usada em situações de intimidade).

Para Lakoff, o ato de cortesia estaria ligado ao agir em conformidade com essas regras. Assim, ela afirma que há construções linguísticas específicas para cada uma das regras acima, com uso regulado pela maneira pela qual os interlocutores compreendem o contexto.

\title{
4.5 A noção de face segundo Goffman (1967)
}

Goffman foi um dos maiores estudiosos das interações sociais do tipo face a face, e dedicou boa parte de sua pesquisa à compreensão dos fenômenos que ocorrem no cotidiano. Em sua obra "A representação do Eu na Vida Cotidiana", deixa evidente suas

\footnotetext{
5 "Politeness usually supercedes: it is considered more important to avoid offense than to achieve clarity. This makes sense, since in most informal conversations, actual communication of ideas is secondary to reaffirming and strengthening of relationships" (p. 297-298).
} 
preocupações acerca do comportamento dos indivíduos quando em contato uns com os outros, discutindo questões como representação, fachada social e outros detalhes concretos de interações na vida cotidiana.

Nessa obra, partindo de analogias entre a vida em sociedade e o teatro, Erving Goffman constrói o conceito das representações e papéis sociais, onde os indivíduos são atores que têm suas respectivas responsabilidades enquanto parte de uma "peça", que se alinha às mais diversas circunstâncias, marcadas por rituais e posições distintivas de outros indivíduos ou grupos sociais. Goffman afirma que

\footnotetext{
quando um indivíduo desempenha um papel, implicitamente solicita de seus observadores que levem a sério a impressão sustentada perante eles. Pede-lhes para acreditarem que o personagem que vêem no momento possui os atributos que aparenta possuir, que o papel que representa terá as conseqüências implicitamente pretendidas por ele e que, de um modo geral, as coisas são o que parecem ser (GOFFMAN: 1975, p. 25)
}

Para o sociólogo, a interação social assume um papel maior do que o simples ato de se comunicar, uma vez que, muitas vezes, a informação ou conteúdo do comunicado não é mais relevante do que o contato estabelecido entre os interlocutores, constituindo-se como um processo fundamental de identificação e de diferenciação dos indivíduos e grupos. Sem a integração em um grupo, ninguém existe, pois é a partir da identificação e aceitação no grupo que se prediz a existência das pessoas. Para Goffman, o desempenho dos papéis sociais tem a ver com o modo como cada indivíduo concebe a sua imagem e pretende mantê-la.

Em 1967, Goffman estudou diversos rituais de interação em Interaction Ritual, quando fez importantes considerações acerca do "alinhamento" (ou linha) entre os interlocutores no processo conversacional. O "alinhamento" pode ser entendido como um padrão de atos verbais e não-verbais dos interlocutores no momento da enunciação; atos esses que expressam a compreensão e avaliação da situação, dos participantes e mesmo de si próprios no processo, levando-os a utilizarem procedimentos que permitam manter o equilíbrio na interação.

Silva (2008b) ilustra esse conceito com o seguinte exemplo: 
“Desta forma, um determinado aluno não se dirige a um professor - que faça parte da mesma vida familiar desse aluno - na sala de aula, da mesma forma como o trata no cotidiano. Assim, abordamos um amigo de forma diferente quando o convidamos para um café e quando pedimos dinheiro emprestado". (p.168)

Essa obra de Goffman também consolida a noção de universal de face, conceito que norteará boa parte das pesquisas posteriores sobre a cortesia verbal. Segundo o autor,

\footnotetext{
"o termo face pode ser definido como um valor social positivo que uma pessoa reclama para si mesma através daquilo que os outros presumem ser a linha tomada por ela durante um contato específico. Face é a imagem do eu delineada em termos de atributos sociais aprovados (...)" (GOFFMAN:1967, p. 5).
}

Goffman define a face como um produto social, uma tentativa natural de se preservar a autoimagem pública, ou seja, uma imagem positiva que a pessoa reivindica para si e faz de tudo para mantê-la. É interessante notar que, mesmo que a face represente o que o homem tenha de mais pessoal e próprio, ela não passa de um conjunto de características oferecido pela sociedade e/ou por ela corroborado. Em outras palavras, a face representa, ao mesmo tempo, uma tentativa de se representar o "eu" social, mas que sofre restrições das normas de aceitação do grupo, precisando ser validado pela sociedade.

Segundo Silva (2008b), nas palavras de Goffman, o termo face provém de expressões em inglês, como to save face (salvar a honra, preservar as aparências) e to lose face (perder a face, perder a reputação). E isso pode acontecer a todo instante, durante o processo comunicativo. Há a constante possibilidade de que a imagem desejada pelo interlocutor não se manifeste, provocando situações de conflito. Goffman (1967) entende que os interlocutores trabalham constantemente durante as interações para manter ou promover sua imagem, utilizando para esse procedimento o termo face-work (trabalho de face).

O trabalho de face envolve uma defesa, que visa à preservação da própria face, e uma proteção, quando direcionado a salvaguardar a imagem do outro. É importante salientar que o simples contato já envolve, por si, um desequilíbrio das faces, que promove então os procedimentos para que as faces sejam preservadas no jogo interacional.

Segundo Galembeck (2008): 


\begin{abstract}
"Para construir, preservar ou restaurar a própria face e a dos demais participantes, o indivíduo utilize determinados procedimentos, denominados processos de figuração ou de negociação de imagem. Esses processos têm por objetivo mostrar que os participantes sabem gerenciar relações, isto é, sabem lidar de forma proveitosa consigo mesmo e com os outros. Com esses procedimentos, previnem- se ameaças potenciais à própria face, numa atitude de resguardo ou defesa." (p.330)
\end{abstract}

A face constitui, assim, um conjunto de desejos e valores que podem ou não ser satisfeitos por ações de outros interlocutores, e há um interesse mútuo, natural, em manter a face e criar um contrato tácito entre os atores: enquanto um interlocutor não ameaçar a face do outro, aquele não ameaça também a sua face. Sendo assim, há um cuidado constante para que não haja ameaça involuntária à face do outro, é preciso procurar sempre uma saída que não leve à perda da própria face.

Segundo Goffman(1970):

\begin{abstract}
"Algumas práticas são principalmente defensivas e outras principalmente protetoras, ainda que, em geral, possa esperar-se que as duas perspectivas sejam tomadas ao mesmo tempo. Ao tratar de salvar a face dos demais, a pessoa deve escolher um caminho que não conduza à perda da sua própria face; ao tratar de salvar a sua própria, deve levar em conta a perda da face que sua ação pode representar para os outros." (p. 1970:20-21)
\end{abstract}

Para Goffman, dois procedimentos são elaborados constantemente no trabalho com as faces:

- Evitar situações ameaçadoras de face: fuga de temas e situações constrangedoras, geralmente por meio indireto, por meio de atenuantes.

- Correção de ações ameaçadoras de face: tentativa de corrigir atos ameaçadores à face, por meio de comportamentos rituais, como pedidos de desculpas para compensar danos. 
Sendo asssim, para Goffman, as noções de cortesia, deferência, discrição, desculpas, entre outros, são infinitamente importantes, pois são condições básicas para que se instaurem as relações sociais entre os interlocutores.

\subsection{A cortesia verbal segundo o modelo de Brown \& Levinson (1987)}

O modelo mais conhecido para o estudo do fenômeno da cortesia é o apresentado em "Politeness: Some universals in language usage", de Brown \& Levinson (1978). Uma revisão desse trabalho foi publicada em 1987. Os autores elaboram a teoria sobre construção da imagem social, a partir de estudos anteriores realizados por Goffman, sobre a noção de face, e também a partir de estudos pragmáticos de Grice, Austin e Searle.

Esse modelo se apoia em três noções básicas: face, atos de ameaça à face (FTA), e estratégias de cortesia. Parte do conceito de imagem social para que, a partir daí, possam estruturar os processos em que ela se desenvolve. Essa imagem apresenta duas vertentes: por um lado, o desejo de não sofrer imposições; por outro, o desejo de ser apreciado.

Nossa noção de face deriva daquela de Goffman (1967) e do
termo popular em inglês que liga a face às noções de estar
constrangido ou humilhado ou "perdendo a face". Assim, a
face é algo em que há investimento emocional e que pode ser
perdida, mantida ou intensificada e que tem que ser
constantemente cuidada numa interação. Em geral, as
pessoas cooperam (e pressupõem a cooperação mútua) na
manutenção a face na interação, sendo essa cooperação
baseada na vulnerabilidade mútua da face. Isto é,
normalmente, a face de qualquer um depende da
manutenção da face de todos os outros e, como se pode
esperar que as pessoas defendam suas faces quando
ameaçadas, e, ao defender suas próprias faces, ameaçam a
face dos outros, geralmente é de interesse de cada
participante manter a face do outro, isto é, agir de forma a
assegurar aos outros participantes que o agente está atento às
pressuposições relativas à face ameaçada
(BROWN\&LEVINSON:1987, p. 61)

Apesar de utilizar a noção de face e território propostos por Goffman, Brown \& Levinson (1987) rebatizam esses conceitos de face positiva e face negativa, respectivamente. Nessa perspectiva, a imagem recebe o nome metafórico de face, e esta é 
revestida emocionalmente, podendo ser perdida, mantida ou acentuada, e deve ser constantemente preservada.

Para os autores, as pessoas, geralmente, cooperam na manutenção da face durante a interação, sendo tal cooperação baseada em uma vulnerabilidade das faces envolvidas. Essa cooperação depende, portanto, da manutenção da face do outro, e, como se pode esperar, as pessoas defendem suas faces quando ameaçadas, e, ao fazerem isso, ameaçam também a face do outro. Sendo assim, é de interesse de ambos manter, além da sua, a face do outro, para evitar confrontos.

A face de um indivíduo consiste de duas necessidades naturais: a liberdade de agir sem ser impedido por outros - "face negativa" (território do eu), e o desejo de aprovação por parte dos outros, ou valorização de suas vontades e anseios individuais (materiais e não materiais) - "face positiva".

A face negativa engloba a contestação aos territórios, reservas pessoais e direitos, ou seja, a liberdade de ação e liberdade de sofrer imposição. É o desejo de não ser impedido de suas ações, por isso a preservação da face negativa implica a não imposição do outro.

A face positiva representa a auto-imagem definida ou personalidade (desejo que sua imagem possa ser aprovada e apreciada) de que os interlocutores necessitam. É o desejo de aprovação social (auto-estima).

A tentativa de manutenção das faces é chamada de face want, ou desejo de preservar faces. A ameaça à face da pessoa representa um ato ameaçador à face (FaceThreatening Act - FTA) e tais atos ameaçadores geralmente requerem alguma forma de atenuação ou reparo para não resultarem em fracasso durante a conversação.

Brown \& Levinson dividem os atos de fala em quatro categorias, organizados de acordo com a face que podem vir a ameaçar. São eles:

d) Atos que ameaçam a face positiva do destinatário: desaprovações, acusações, críticas, refutações, censuras, insultos, escárnios e outros comportamentos vexatórios.

c) Atos que ameaçam a face negativa do destinatário: elogios, ofensas, agressões, perguntas impróprias, pedidos, ordens, proibições, conselhos e outros atos contrários e proibitivos; 
b) Atos que ameaçam a face positiva do emissor: autoconfissões, desculpas, autocríticas, e outros comportamentos auto-degradantes;

a) Atos que ameaçam a face negativa do emissor: agradecimentos, excusas, aceitação de ofertas. Promessas, pelas quais empenhamo-nos em fazer, em um futuro próximo ou distante, contanto que se evite lesar o território próprio;

A figura seguinte ilustra esses atos, conforme identificado pelos autores:

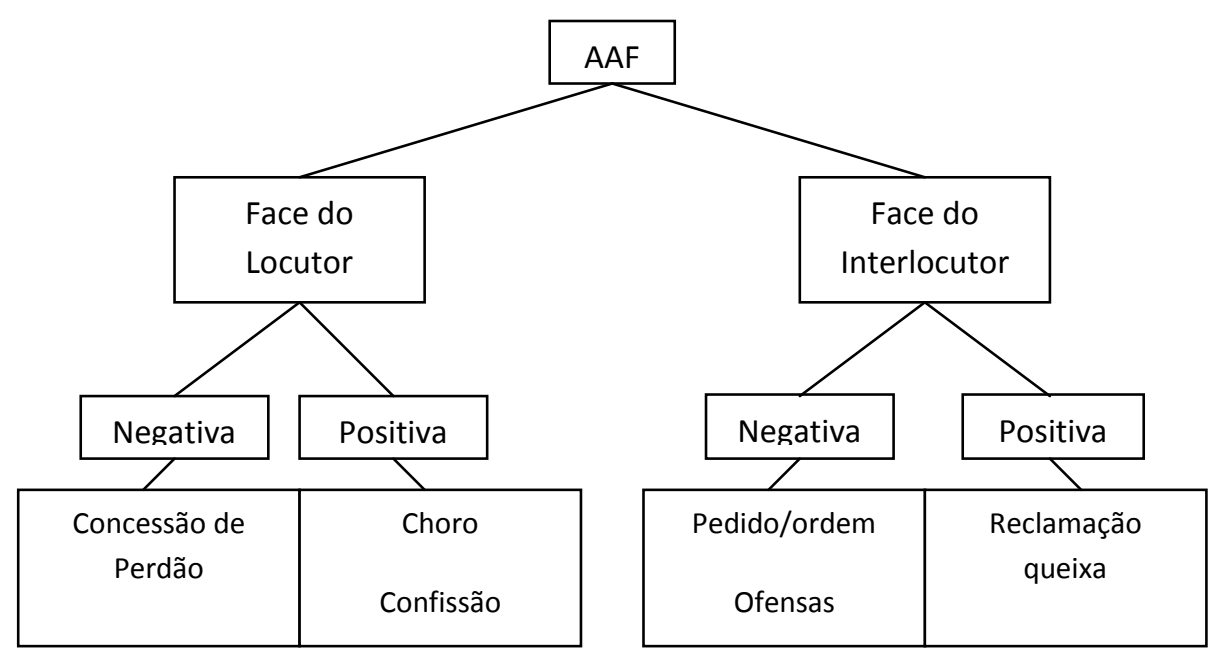

Figura10. AAF propostos por Brown \& Levinson

Kerbrat-Orecchioni (2006) faz uma observação importante acerca desses atos:

"Notemos que um mesmo ato pode se inscrever sumultaneamente em diversas categorias (mas, geralmente, com um valor dominante), por exemplo: ao mesmo tempo em que ameaçam a face negativa do destinatário, a ordem e a interpelação ameaçam a face positiva do destinatário, no caso da ordem, e do falante, no caso da interpelação". (p.7980)

Assim, cortesia é vista, primeiramente, em termos de estratégias adotadas pelos atores para atenuar o impacto daqueles atos potencialmente ameaçadores à face dos interlocutores. A escolha da estratégia de cortesia que o locutor aplica a certo ato de fala é determinada por esses três fatores. 
Dessa forma, os interlocutores calculam o peso dos seus atos de fala a partir de três variáveis sociais: a distância social percebida entre o ouvinte (interlocutor) e o falante (locutor), a diferença de poder percebida entre eles e o peso cultural do ato de fala.

Segundo Galembeck, (2008):

\begin{abstract}
"Acrescente-se que as noções de face positiva e face negativa relacionam-se, genericamente, com a polidez e o gerenciamento de relações interpessoais. Ao criar uma imagem positiva de si mesmo (ou procurar fazê-lo), o indivíduo mostra, em conseqüência, que tem a capacidade de interagir de forma respeitosa. Com isso, ele exibe apenas o que julga ser positivo, demonstra o desejo de não se criar qualquer tipo de constrangimento ao seu parceiro conversacional. Da mesma forma, ele esconde aquilo que deseja ver exibido, para não criar situações embaraçosas para si e demais interlocutores. Do mesmo modo, a criação de uma imagem positiva do interlocutor demonstra que o falante tem a competência para estabelecer relações equilibradas e respeitosas com seu parceiro conversacional. Aliás, a polidez, assim como a construção e a preservação da face, é um fenômeno que opera em mão dupla, pois deve haver equilíbrio entre a própria imagem e a do outro." (p. 331-332)
\end{abstract}

De acordo com esse modelo, a imagem social é vulnerável, e por isso constantemente são utilizados procedimentos para atenuar potenciais ameaças. Os interlocutores empregam estratégias mitigadoras de acordo com a avaliação do risco para a imagem dos participantes. O termo estratégia é utilizado pelos autores, visto que nenhum outro termo implicará um elemento racional que engloba tanto uma atitude consciente quanto inconsciente.

Entendendo desta maneira, é possível discernir que os interlocutores têm consciência da ameaça iminente e constante na interação, percebem a necessidade de serem corteses e polidos em situações sociais para mitigar os efeitos dos atos ameaçadores e de face, mas nem sempre agem de maneira consciente na escolha das estratégias de cortesia a serem utilizadas. Por isso o termo estratégia implica um termo racional, mas não necessariamente consciente.

Para Brown \& Levinson, existem algumas intenções presentes nas interações verbais, quando se quer evitar os problemas provocados por atos ameaçadores de face: em primeiro 
lugar, o desejo de comunicar o conteúdo de um ato ameaçador; em segundo, o desejo de ser eficiente; e, por último, o desejo de manter, sempre que possível, a face do outro.

Assim, diante da possibilidade de um FTA, existem, no modelo, as seguintes opções:

a) fazê-la de forma direta, sem ação reparadora;

b) fazê-la, com cortesia positiva: aponta para face positiva do ouvinte (interlocutor), de maneira que demonstra que, em algum nível, o falante (locutor) deseja as mesmas coisas que ele (mostra pertencimento ao mesmo grupo);

c) fazê-la, com cortesia negativa: aponta para satisfazer a face negativa do ouvinte (interlocutor); seus desejos básicos de manutenção de território e de autodeterminação; baseia-se no distanciamento, na formalidade e deferência, e consiste em demonstrar que o falante não pretende interferir na liberdade de ação do interlocutor.

d) fazê-la de maneira encoberta, de forma indireta (off Record);

e) não fazê-la.

Essas opções se encaixam nas seguintes estratégias:

1- On record: o locutor tem a intenção de assumir seu ato linguístico, de se comprometer diante do que fala.

2- Off record: o locutor evita responsabilizar-se por seus enunciados, tenta não se comprometer diante dos atos ameaçadores de face que produz na interação. Deixa ao seu interlocutor a responsabilidade de interpretação do que enuncia.

3- Bald on record: o locutor não está muito preocupado em como dizer alguma coisa, mas no que diz. Tem o objetivo maior de comunicar algo, não dando atenção à forma como uma determinada mensagem é por ele transmitida. O uso de verbos no imperativo é um exemplo deste tipo de realização comunicativa.

A figura seguinte ilustra essas estratégias: 


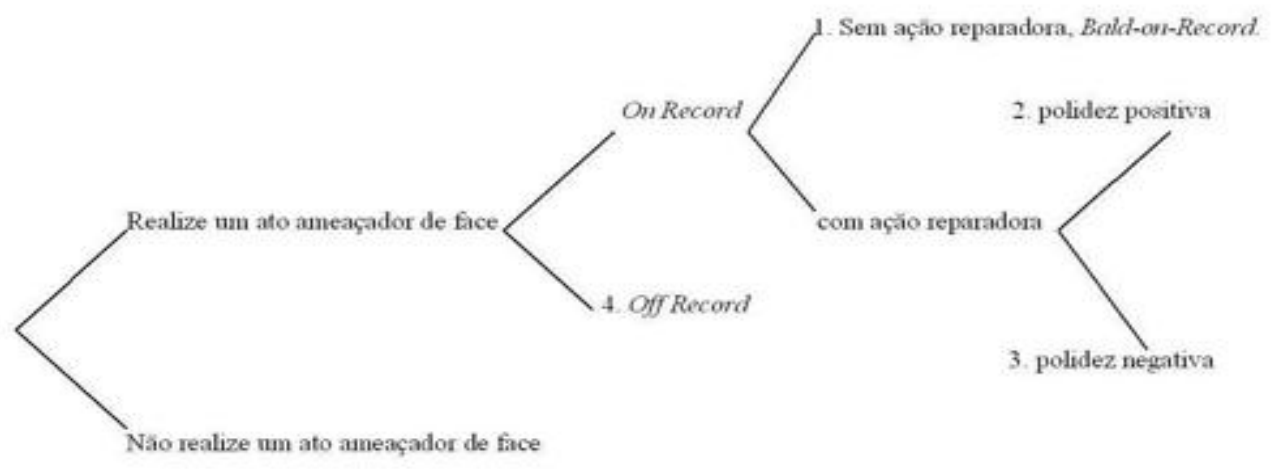

Figura 11. Possíveis estratégias para realizar um FTA (BROWN\&LEVINSON:1987, p. 69)

Com relação às concepções de cortesia, convém esclarecer que:

- A cortesia positiva consiste em satisfazer, parcialmente, as aspirações do interlocutor, dando a entender que há desejos comuns entre ambos.

- A cortesia negativa ocorre ao se empregar expressões que evitam imposições ao interlocutor, como o uso de evasivas, como o desejo de não querer comprometer -se com o outro.

- A cortesia indireta (off record) representa um ato de fala indireto, quem o enuncia deixa implícito um número de interpretações defensáveis. Essa estratégia permite ao locutor emitir FTA's, evitando responsabilidades e deixando a interpretação por conta do interlocutor.

\subsection{Estratégias de Cortesia (Brown \& Levinson)}

\section{a) Cortesia Positiva}

Orientada para a face positiva do interlocutor, gera solidariedade e alimenta o desejo que se tem de ser admirado pelos outros. Nesse caso, o locutor deixa claro que pertence ao mesmo grupo social do interlocutor, e está disposto a interagir cooperativamente no sentido de diminuir a distância social. Apresentamos, a seguir, as estratégias propostas pelos autores, seguindo a tradução e organização presente em Silva (2008, p.182-184): 
i) Veicular que o interlocutor é admirável, interessante:

estratégia 1 - dar atenção aos interesses, necessidades, desejos e qualidades do interlocutor;

estratégia 2 - exagerar a aprovação, a simpatia;

estratégia 3 - intensificar o interesse.

ii) Reivindicar acolhimento do grupo:

estratégia 4 - usar marcas de identidades do grupo.

iii) Reivindicar aspectos em comum, como ponto de vista, opiniões, atitudes, conhecimentos, empatia:

estratégia 5 - buscar concordância;

estratégia 6 - evitar discordância;

estratégia 7 - pressupor, levantar terreno em comum;

estratégia 8 - fazer "brincadeiras".

iv) Veicular que locutor e interlocutor são cooperativos:

estratégia 9 - declarar ou pressupor o conhecimento do locutor concernente aos desejos do interlocutor;

estratégia 10 - fazer ofertas;

estratégia 11 - manifestar atitude de otimismo;

estratégia 12 - incluir locutor e interlocutor na atividade;

estratégia 13 - apresentar (ou perguntar por) razões;

estratégia 14 - assumir ou declarar reciprocidade.

v) Satisfazer o desejo do interlocutor:

estratégia 15 - dar "presentes" ao interlocutor (simpatia, cooperação). 


\section{b) Cortesia Negativa}

Orientada para a proteção da face negativa, necessidade de evitar a imposição ao interlocutor, mantendo seu território e não interferindo na liberdade de ações. Está ligada a um comportamento respeitoso, evitando tópicos polêmicos e mais distantes do interlocutor.

\section{i) Não ser direto:}

estratégia 1 - ser convencionalmente indireto.

ii) Não presumir ou assumir; minimizar o que se assume sobre os desejos do interlocutor:

estratégia 2 - utilizar perguntas e rodeios.

iii) Não forçar o interlocutor e dar a opção de não fazer o que se pede:

estratégia 3 - adotar atitude pessimista;

estratégia 4 - minimizar a imposição;

estratégia 5-manifestar deferência.

iv) Ao comunicar os desejos, não fazer imposição ao interlocutor, dissociando-o da violação:

estratégia 6 - desculpar-se, justificar-se;

estratégias 7 e 9 - impessoalizar locutor e interlocutor;

estratégia 8 - colocar o ato de ameaça à face como regra geral.

v) Reparar outros desejos, derivados da face negativa:

estratégia 10 - não colocar o interlocutor em débito.

c) Indiretividade (off Record)

São estratégias utilizadas para que o locutor não se comprometa com o que diz, deixando espaços para diversas possibilidades de interpretação, passando para o interlocutor a interpretação de seus enunciados. Por meio da indiretividade, o locutor pode emitir atos de ameaça à face do interlocutor, evitando seu comprometimento. 
Estratégia 1. Dar pistas.

Estratégia 2. Dar chaves de associação.

Estratégia 3. Pressupor.

Estratégia 4. Diminuir a importância.

Estratégia 5. Exagerar, aumentar a importância.

Estratégia 6. Usar tautologias.

Estratégia 7. Usar contradições.

Estratégia 8. Ser irônico.

Estratégia 9. Usar metáforas.

Estratégia 10. Fazer perguntas retóricas.

Estratégia 11. Ser ambíguo.

Estratégia 12. Ser vago.

Estratégia 13. Hipergeneralizar.

Estratégia 14. Deslocar o ouvinte.

Estratégia 15. Ser incompleto, usar elipse.

\subsection{Leituras críticas do modelo de Brown \& Levinson}

Kerbrat-Orecchioni $(2005,2006)$ faz uma reflexão sobre a teoria de Brown \& Levinson (1987), concluindo que os atos de fala, seguindo a linha dos autores citados, tomam uma dimensão de atos ameaçadores de face (FTAs) apenas, deixando de lado outros aspectos importantes da questão.

Kerbrat-Orecchioni $(2005,2006)$ aborda de maneira crítica o modelo apresentado por Brown \& Levinson, e propõe um aperfeiçoamento, acrescentando o conceito de FFA (Face Flattering Acts), ou Anti-FTA, que podem ser traduzidos por "atos de valorização da face". Para a autora, na interação, assim como há atos que ameaçam a face, há também atos que valorizam a face, e a interação é um "incessante e sutil jogo de pêndulo entre FTAs e FFAs". 


\begin{abstract}
"A esse modelo reprovou-se, sobretudo, uma concepção excessivamente pessimista, e até mesmo "paranóide", da interação - representando os indivíduos em sociedade como seres vivos sob ameaça permanente de FTAs de todo gênero, e passando seu tempo a montar guarda em torno de seu território e de sua face. Com efeito, é incontestável que Brown e Levinson reduzem demais a polidez (cortesia) à sua forma "negativa": bastante revelador desse aspecto é o fato de que, buscando reciclar a noção de ato de fala na perspectiva de uma teoria da polidez lingüística, eles apenas tenham focalizado os atos potencialmente ameaçadores para as faces, sem pensar que alguns atos de fala também podem ser valorizantes para essas mesmas faces, como o elogio, o agradecimento ou os votos. Para explicá-los, é indispensável introduzir no modelo teórico um termo suplementar para designar esses atos que são, em alguma medida, o lado positivo dos FTAs: chamamos esses "anti-FTAs" de "FFAs"." (KERBRAT-ORECCHIONI:2006, p.81-82)
\end{abstract}

Assim sendo, a autora divide os atos de fala em duas grandes famílias:

a) Atos de fala "negativos" - FTAs, que produzem efeitos basicamente negativos para as faces;

b) atos de fala "positivos" - FFAs, que produzem elogios e agradecimentos.

A autora finaliza explicando que a cortesia negativa é de natureza abstencionista ou compensatória, ou seja, serve para "evitar produzir um FTA", abrandando, sempre que possível, por meio de alguns procedimentos, sua efetiva realização, quer se referindo à face negativa (ordem, pedido) ou à face positiva (crítica, julgo) do interlocutor. A cortesia positiva seria, então, de natureza produtiva, pois consiste em efetuar um FTA para a face negativa (presente) ou positiva (elogio) do interlocutor, ocupando um lugar tão importante quanto a polidez negativa.

Meier (1995) reexamina a teoria da cortesia de Brown \& Levinson e a sua aplicação em estudos subsequentes. O autor levanta sérios questionamentos observando seu valor para estudos empíricos. Oferece uma visão alternativa de cortesia, delineando uma nova abordagem para a análise dos atos de reparação, colocados num enquadre mais compreensivo da interação social. 


\begin{abstract}
"É momento de reexaminar criticamente a estrutura proposta por B/L e suas manifestações no tratamento do assim chamado fenômeno de polidez. O propósito deste trabalho é fazer exatamente isto, explorando como problemas observáveis podem ser ao menos parcialmente atribuídos às inconsistências da teoria de B/L. (op. cit, p.118)"
\end{abstract}

Meier defende uma visão mais ampla do fenômeno, sugerindo que este não esteja associado apenas a atos específicos de fala, ou estratégias pontuais, quantificáveis, e sim a situações interculturais e interacionais. O autor propõe que seja analisado do ponto de vista da "adequação situacional", visto que a cortesia só existe em termos do que se é socialmente aceitável na interação .

Sendo assim, sob este enfoque, a cortesia somente poderia ser julgada em relação a um contexto particular e às expectativas particulares do interlocutor e suas interpretações associadas. Ela seria, assim, mais parte do sentido do discurso, do que de uma sentença, norma, ou regra.

O autor cita que, se assim considerarmos, certas formas de tratamento, por exemplo, não seriam descritas como mais polidas ou cordiais do que outras, mas dentro de uma comunidade de fala particular, trariam uma certa adequação contextual, as quais poderiam ser apropriadas (cordiais) em determinados contextos e inapropriadas (descordiais) em outro.

Outro problema observado está no campo da classificação das estratégias positivas e negativas da cortesia. O autor cita que Leech (1983), por exemplo, classificaria desculpas (reparação) como estratégias positivas de cortesia, ao passo que Holmes (1990), argumenta que desculpas podem ser direcionadas tanto aos desejos (necessidades) da face negativa quanto da positiva.

Quanto aos atos de reparação, o autor sugere que este funcione para remediar qualquer dano causado à imagem de um participante mediante o estabelecimento de uma ligação de responsabilidade entre este e seu comportamento, quando este comportamento for considerado nocivo, ou abaixo de um padrão esperado, se comparado a um grupo particular de referência. 
"Note que, em forte contraste com B/L e aqueles que utilizam sua estrutura, eu postulo que o Ato de Reparação seja um dispositivo de "salva-imagem", no que diz respeito ao Falante (não ao Ouvinte), tornado agora, o Falante, a figura central". (op cit, p. 127).

O Ato de Reparação é, dessa forma, uma tentativa de mostrar que o locutor é bom (a despeito de ter violado uma norma social) e pode-se confiar nele no futuro, que agirá como previsto, de acordo com as normas sociais de um grupo particular de referência (i.e. agir apropriadamente, adequadamente ou com decoro). Assim, a preocupação com a face do interlocutor é somente um subproduto da tentativa de salvar a face do locutor. (p. 128)

O gráfico seguinte ilustra o conceito de Meier:

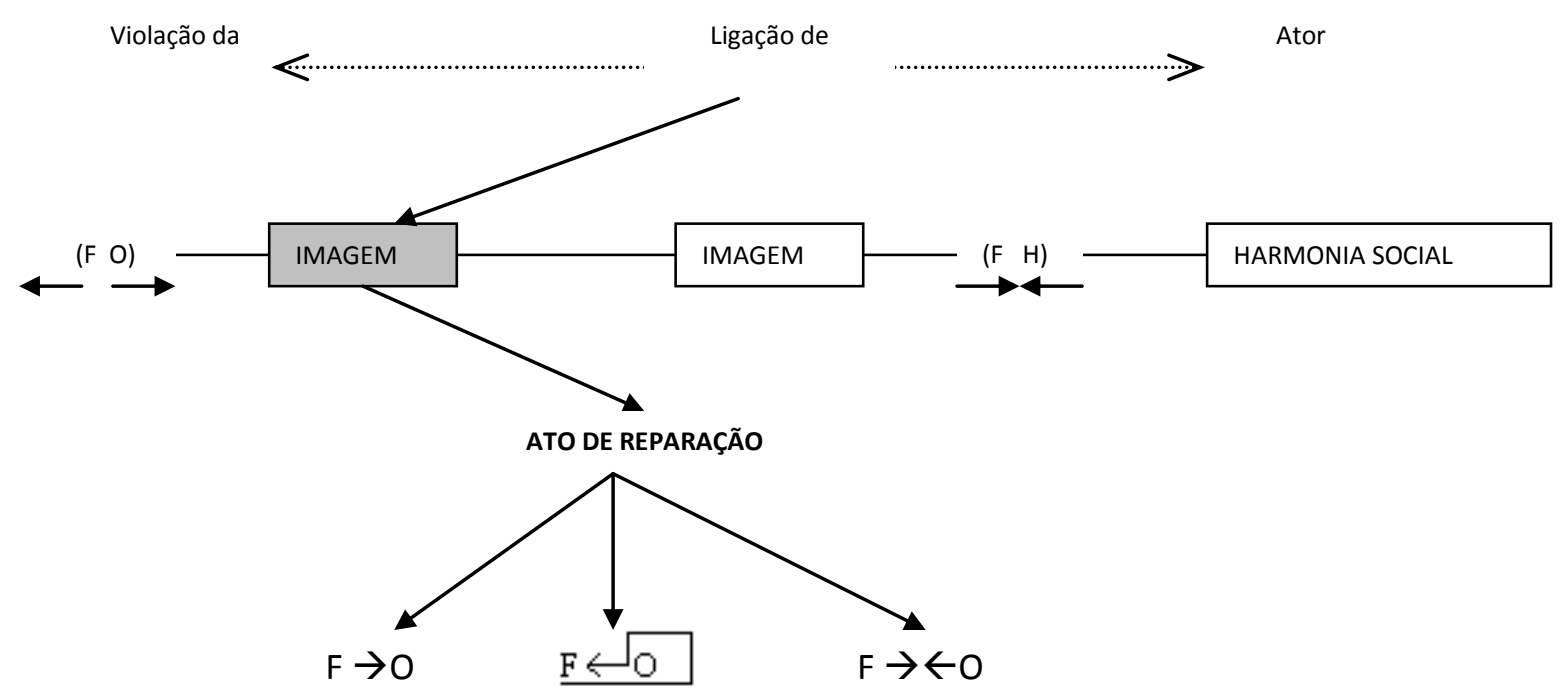

Figura 12 . Modelo de Ato de Reparação (adaptado de Snyder et al. 1983)

O tipo $\mathrm{F} \rightarrow \mathrm{O}$ envolve o locutor vendo as coisas do jeito do interlocutor, expressando apreciação pelos sentimentos deste. Exemplos disto incluem: expressar empatia; expressar sentimentos negativos; afirmação explícita de má performance; reparar.

A segunda maior estratégia, por outro lado, envolve levar o interlocutor a ver as coisas do jeito do locutor. Nesta categoria estão as desculpas, as justificativas, os apelos para a compreensão do interlocutor, etc.

A terceira categoria é destacada como sendo um encontro entre o locutor e o interlocutor, um "meio-caminho"; neste caso o foco está sob a "absolvição", uma tentativa 
de esquecer o passado. Fórmulas rotineiras, bem como expressar esperança pela continuação do status-quo presente, ou retorno ao status-quo anterior são exemplos dessa terceira categoria.

Tal abordagem para o comportamento do Ato de reparação, dessa forma, não assume nenhuma categoria pré-ordenada de cortesia para o ato de fala, ou para tipos de estratégias particulares. Ao invés disso, ajuda a identificar o que se percebe como apropriado ou adequado para uma dada situação.

Rosa (1992) apresenta estudos de procedimentos de atenuação, e tais fenômenos são considerados recursos destinados à preservação de face em interações. A autora entende que os marcadores conversacionais, além de cumprir funções importantes na organização textual, tais como a coesão, dêixis discursiva, entre outros, também funcionam como elementos discursivos.

A pesquisadora afirma que é a relevância interacional do contexto que determina o emprego de uma estratégia específica - e de marcadores específicos - com vistas a manter a cooperação (requisito essencial a toda interação) e a mútua preservação da face dos interlocutores.

Segundo Rosa, os conceitos de atenuação e polidez muitas vezes se confundem, pois ambos são estratégias de preservação de face, e buscam a estabilidade da harmonia interacional. A autora alerta ainda que atenuação implica cortesia, mas cortesia é uma noção que extrapola os limites da atenuação. Exemplo disso está nas diversas estratégias descritas por Brown\& Levinson (1987), que não estão somente restritas ao campo do abrandamento, da atenuação.

O quadro abaixo exemplifica os tipos de marcadores usados nas interações cotidianas para reduzir possíveis efeitos indesejados que um ato de fala pode ter sobre o interlocutor ou mesmo sobre o locutor:

\begin{tabular}{|c|c|c|c|}
\hline Categorias & Tipos & Subtipos & Ocorrências \\
\hline $\begin{array}{c}\text { Marcadores que } \\
\text { promovem o } \\
\text { apagamento da } \\
\text { instância da } \\
\text { enunciação }\end{array}$ & $\begin{array}{c}\text { Marcadores de } \\
\text { Distanciamento }\end{array}$ & Impessoais & Parece que, parece, é possível que \\
\cline { 2 - 4 } & $\begin{array}{c}\text { De Indeterminação do } \\
\text { Sujeito }\end{array}$ & Dizem que, diz-se, diz que \\
\hline
\end{tabular}




\begin{tabular}{|c|c|c|c|}
\hline \multirow{10}{*}{$\begin{array}{l}\text { Marcas da } \\
\text { Enunciação }\end{array}$} & \multirow{4}{*}{$\begin{array}{l}\text { Marcadores de } \\
\text { Opinião }\end{array}$} & Expressões Verbais & $\begin{array}{l}\text { Eu acho que, eu creio que, eu suponho } \\
\text { que, eu acredito que, me parece que, } \\
\text { eu considero, eu vejo, eu sinto que, eu } \\
\text { entendo que, eu tenho a impressão } \\
\text { (de) que }\end{array}$ \\
\hline & & Locuções adverbiais & $\begin{array}{l}\text { Para meu gosto, pessoalmente, para } \\
\text { mim, eu por mim, na minha opinião, } \\
\text { naquilo que me diz respeito }\end{array}$ \\
\hline & & Prefácios & $\begin{array}{l}\text { A minha impressão é (de) que, a } \\
\text { impressão que eu tenho é a seguinte, é } \\
\text { uma opinião particular minha, o que eu } \\
\text { sinto é o seguinte, eu tenho a } \\
\text { impressão seguinte, a minha } \\
\text { visão...é..., a minha visão... é uma visão } \\
\text { assim que... }\end{array}$ \\
\hline & & Posfácios & $\begin{array}{l}\text { Mas esta é a minha impressão, essa é a } \\
\text { minha visão, pelo menos } \\
\text { é a minha impressão né? }\end{array}$ \\
\hline & \multirow[b]{2}{*}{ Hedges } & $\begin{array}{l}\text { Hedges indicadores de } \\
\text { atividades cognitivas }\end{array}$ & $\begin{array}{l}\text { Assim, quer dizer, vamos dizer, } \\
\text { digamos, digamos assim, sei lá, não sei }\end{array}$ \\
\hline & & $\begin{array}{l}\text { Hedges indicadores de } \\
\text { incerteza }\end{array}$ & $\begin{array}{l}\text { Talvez, quem sabe, não sei, não sei se, } \\
\text { sei lá, possivelmente, provavelmente, } \\
\text { praticamente, às vezes, quando } \\
\text { possível, vez por outra, normalmente, } \\
\text { geralmente, na maior parte das vezes, } \\
\text { no geral, em geral, muitas vezes, } \\
\text { eventualmente, habitualmente, numa } \\
\text { certa medida, de certa forma, de uma } \\
\text { certa forma, de um modo geral, numa } \\
\text { certa situação, assim em termos gerais, } \\
\text { de certa maneira, de uma certa } \\
\text { maneira, de certo modo, falando bem } \\
\text { em termos gerais, muito por cima, a } \\
\text { bem dizendo como a coisa funciona }\end{array}$ \\
\hline & \multirow[t]{3}{*}{$\begin{array}{l}\text { Marcadores de } \\
\text { Rejeição }\end{array}$} & $\begin{array}{c}\text { Frases } \\
\text { estereotipadas }\end{array}$ & $\begin{array}{l}\text { Se não me falha a memória, que eu me } \\
\text { lembre, que eu me } \\
\text { lembro de momento, que } \\
\text { eu saiba, se não estou } \\
\text { enganado } \\
\text { Não sei se..., mas, etc. }\end{array}$ \\
\hline & & “Mas-prefácios" & $\begin{array}{l}\text { Eu não me lembro bem... } \\
\text { o que eu lembro é que, } \\
\text { não :: sei bem...eu sei } \\
\text { que }\end{array}$ \\
\hline & & $\begin{array}{l}\text { Prefácios } \\
\text { Contrastivos }\end{array}$ & $\begin{array}{l}\text { Antes disso eu quero } \\
\text { dizer uma coisa, etc. }\end{array}$ \\
\hline & $\begin{array}{c}\text { Marcadores } \\
\text { Metadiscursivos }\end{array}$ & ----- & \\
\hline
\end{tabular}

Tabela 9: Tipos de Marcadores de Atenuação (ROSA:1992, p. 61) 
Galembeck $(1999,2008)$ segue nessa direção, abordando o uso dos marcadores de atenuação como recurso do locutor para salvaguardar sua própria face e a do interlocutor, uma vez que tendem a suavizar a força do ato ilocutório, tornando-o menos impositivo e invasivo. (GALEMBECK:2008, p. 323).

O autor registra, também, que os marcadores de atenuação podem ser

\begin{abstract}
“...marcas de polidez, ou gerenciamento de relações, assim entendidas aquelas que denotam a preocupação em estabelecer (ou restabelecer) uma situação de igualdade e respeito mútuo entre os participantes" (GALEMBECK:2008, p. 324).
\end{abstract}

\title{
4.9 Acerca da Descortesia
}

Recentemente, alguns trabalhos no âmbito da Pragmática Linguística têm usado o termo "descortesia" para se referir a violações de contratos conversacionais, ou quando há agressividade e violência verbal explícitas em enunciados. É o caso do trabalho de Andrade(2008), Rodríguez\&Lara $(2006,2008)$ e Aquino (2008), só para citar alguns.

Rodríguez\& Lara (2008) afirmam que, enquanto a cortesia tem como propósito "darse bem com os demais", mediante a manutenção de uma imagem social positiva, ou comportamentos aceitos social e interlocutivamente, a descortesia centra sua produção na desconstrução da imagem social e positiva do interlocutor, por meio da produção de atos descorteses.

\footnotetext{
"não são sempre as regras de cortesia que regem a conversação e a comunicação em geral. Há situações de comunicação em que, longe de tentar se dar bem com o nosso interlocutor, nosso interesse centra-se em deteriorar e destruir sua imagem" (p.16)6
}

A descortesia se instaura na aplicação de atos de fala que insultam, depreciam o interlocutor, podendo se dar a partir de um descontrole emocional, ou como estratégia para ironizar ou mesmo agredir a face positiva do outro no processo interacional.

\footnotetext{
6 “...no son siempre las reglas de cortesía que gobiernan la conversación y la comunicación en general. Existen situaciones comunicativas en las que, lejos de pretender quedar bien con nuestro interlocutor, nuestro interés se centra en deteriorar y destruir su imagen"
} 
Rodriguez\&Lara(2008) distinguem o ato agressivo - que não intenta necessariamente em um dano, mas sim trata-se de um procedimento dissuasivo - e o violento, que prevê o dano, físico ou psíquico, e tem como aliados as desigualdades e as relações de poder.

Assim, afirmam que os atos inibitórios ou dissuasivos são os intimidadores, o "atacar para defender", e para manter uma postura forte diante do grupo. Entendem que uma pessoa pode ser verbalmente agressiva, utilizando essa agressividade para manter sua postura e suas posições, ainda que não cheguem a ser violentas.

Já o ato ilocutivo que emana violência tem como propósito único desafiar o interlocutor, prejudicá-lo socialmente, por meio de insultos, ridicularização, tomada da palavra, não deixando que o outro a tenha ou se manifeste; são todos atos que atentam contra a dignidade da pessoa.

\footnotetext{
"Estamos muito acostumados a falar de violência na forma de assassinatos, esfaqueamentos, tiroteios, atos que, é claro, são muito violentos, mas nós não reconhecemos a violência em um insulto .." (p.18)7
}

Entre algumas estratégias de descortesia e agressividade verbal citadas pelos autores, estão:

a) retenção de turno, ignorando as tentativas de (re)tomada;

b) tomada de turno para reafirmar a mesma ideia de outro interlocutor, de maneira que traga para si o enunciado, tornando-se "autor primário";

c) interrupção aberta e explícita do turno, com objetivo claro de boicotar a intervenção do interlocutor, ou afetar sua imagem;

d) tomada de turno grosseira para expor opiniões contrárias às expostas pelo interlocutor;

e) desconhecer ou ignorar o turno de fala, sabotando e se negando a contribuir com a progressão temática do discurso;

f) desprestigiar o interlocutor por meio de insultos, ou dizer que o outro mente, etc.

\footnotetext{
7 "Estamos muy acostumbrados a hablar de violencia en forma de asesinatos, puñaladas, disparos, actos que, por supuesto, son altamente violentos, pero no llegamos a reconocer violencia en un insulto.." (p.18)
} 
É importante salientar que um ato só pode ser considerado "descortês" se observados o contexto e as condições de produção em que este foi empregado. Uma expressão tida como descortês pode não ser descortês em algumas situações, e atos de fala considerados corteses podem ser considerados descorteses, se pensarmos em termos de ironia com ameaça direta à face do interlocutor.

\subsection{Proposta de análise da Cortesia verbal}

Tendo em vista todo o referencial sobre Cortesia Verbal anteriormente exposto, propomos o seguinte quadro, que, segundo entendemos, sintetiza os principais aspectos abordados que, de certa forma, possuem alguma relação entre si.

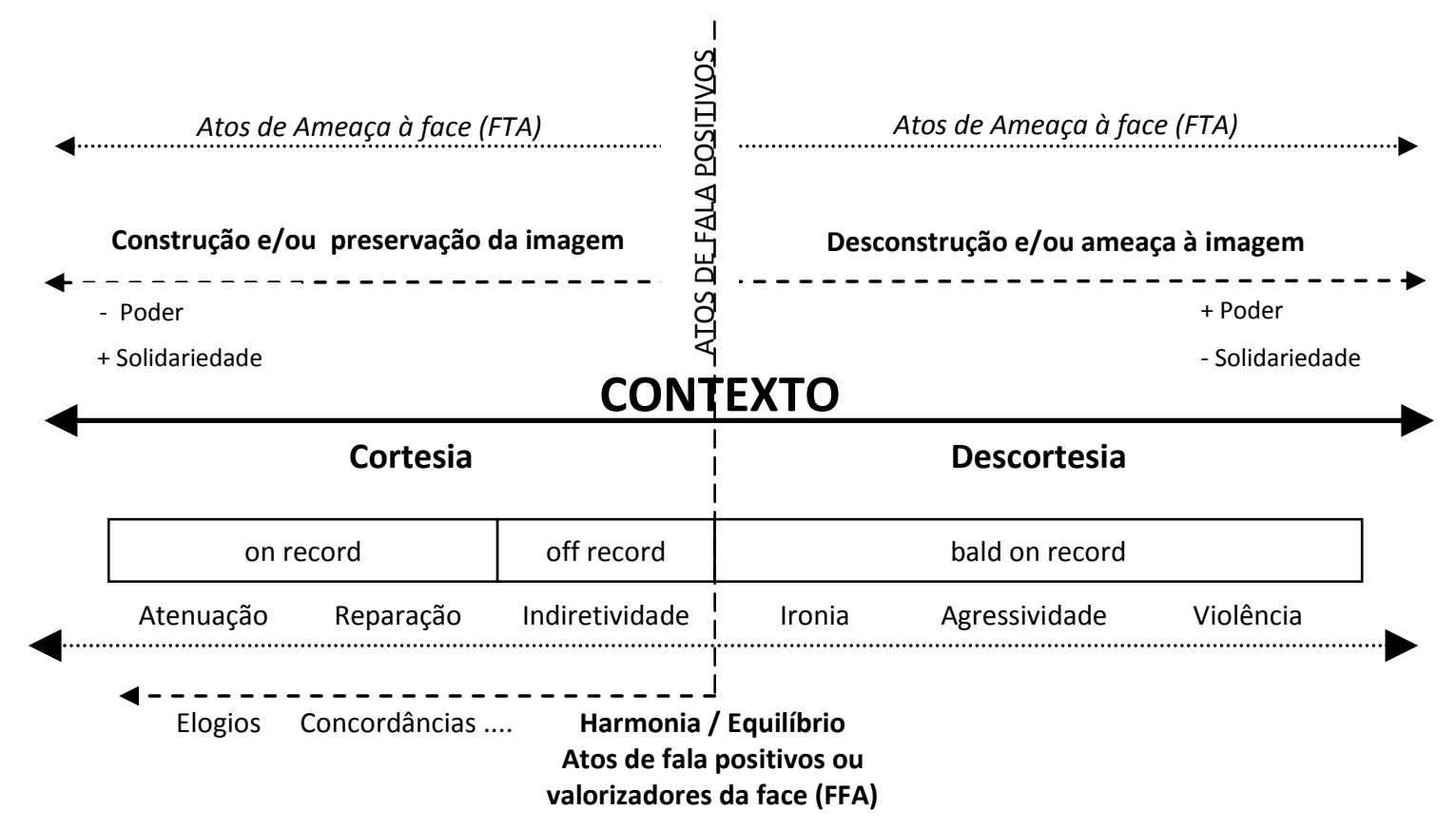

Figura 13. Representação da Cortesia e Descortesia Verbal.

O gráfico acima apresenta o contexto como modulador de cortesia, onde, a partir do centro, temos os atos valorizadores de face, que caminham na direção desta, utilizando-se de suas estratégias para manter o equilíbrio e a harmonia do diálogo, por meio de elogios, concordâncias, agradecimentos, etc. Diante de uma situação de ameaça à face, em que o 
locutor agiu involuntariamente, ou mesmo se arrependeu de seu ato de fala, e tem interesse em recuperar o equilíbrio, encontramos, à esquerda, as estratégias de atenuação, reparo e indiretividade, que podem ser usadas de acordo com a intenção pragmática e a situação de interação.

Se, por outro lado, o interesse do locutor for ferir a imagem do interlocutor, parte para o lado direito do gráfico, iniciando com a simples ironia, passando pela agressividade e chegando até a violência verbal.

Pretendemos, a partir deste quadro, proceder à análise da cortesia nas conversações digitais, procurando entender em que medida os interlocutores se valem das mesmas estratégias da conversação face a face prototípica, e verificando, também, se há formas e recursos próprios de cortesia no ambiente virtual aqui sob análise. 


\section{Capítulo V \\ A cortesia verbal na conversação digital}

\subsection{O Processo de Equilíbrio interacional: a busca pela harmonia na conversação digital}

Assim como nas conversações naturais, as pessoas, nas conversações digitais, têm por hábito iniciar o contato cumprimentando-se, variando a forma de acordo com o grau de amizade e/ou intimidade. Normalmente, as fórmulas de saudação são iguais às que usamos regularmente em nossas relações interpessoais no ambiente real:

Marcos diz: Boa noite!

Anita feliz diz: boa noite!!!!!!!!!!

Inquérito 28

$(12: 43)$ Fazendo as malas $(8)$ oi

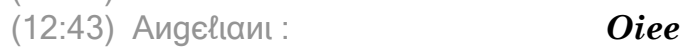

Inquérito 12

TH I A G Ã O ... diz: oiiiii

Jaah - Sai do chão, sai do chão, a torcida do Mengão * * diz: Oiiii ..

Inquérito 14

$(20: 28)$ flavio: ola tudo bem

$(20: 28)$ Helena: tudo

Inquérito 20

As repetições de letras são utilizadas para simular a entonação desejada, que não é possível por meio da escrita convencional (oiee, oiii). Esse procedimento também indica uma relação de proximidade e maior solidariedade com o interlocutor, podendo ser considerado um aspecto da cortesia verbal digital.

Entre outras possibilidades de abertura, estão as formas de tratamento personalizadas, os chamamentos carinhosos e por apelidos, que, além de demonstrar afeto e desejo de equilíbrio dialógico, denotam também proximidade e solidariedade com o interlocutor: 


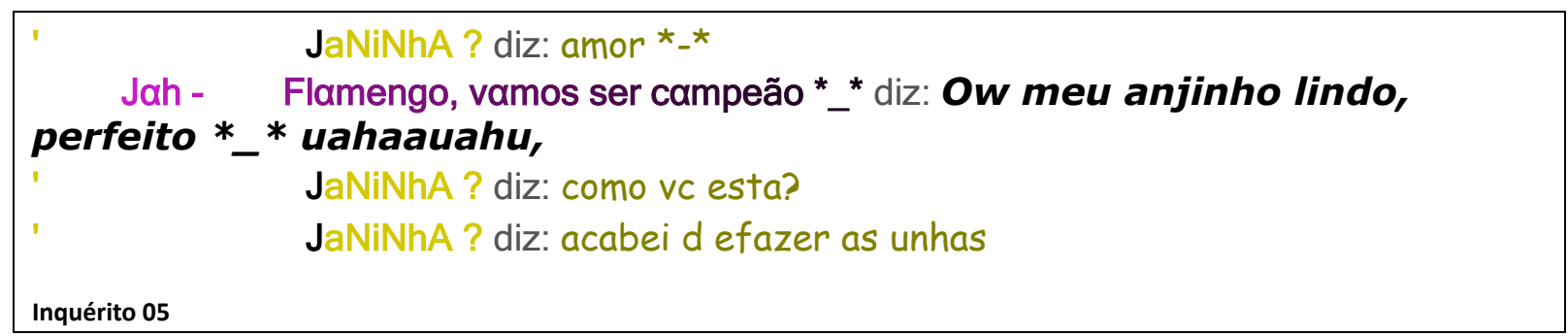

Quanto às formas de tratamento propriamente ditas, é natural que, em qualquer diálogo, há que se observar um estatuto de comunicação de proximidade ou distância social, poder ou solidariedade, para daí se proceder à escolha das formas adequadas. No corpus coletado, as interações acontecem entre pessoas com grande proximidade, amigos e colegas de estudo, além de familiares, o que nos permite fazer algumas considerações sobre relações desse tipo no ambiente virtual.

Há muitas ocorrências da forma vc como referência direta ao interlocutor, o que indica ser esta própria das conversações digitais. Entendemos que a forma vc, empregada largamente nas ferramentas de interação na Internet como referência à segunda pessoa do discurso, seja uma forma abreviada de você, constituindo-se, portanto, numa variante lexical. Acreditamos que esse uso foi instaurado certamente em decorrência da velocidade com que as informações são processadas virtualmente, principalmente quando há interação simultânea com diversos meios para dinamizar a conversa. Muitas vezes, conforme se pode observar no exemplo que segue, além da forma $v c$, há também a opção do locutor de não utilizar uma forma de tratamento lexicalizada, optando por "ocultá-la":

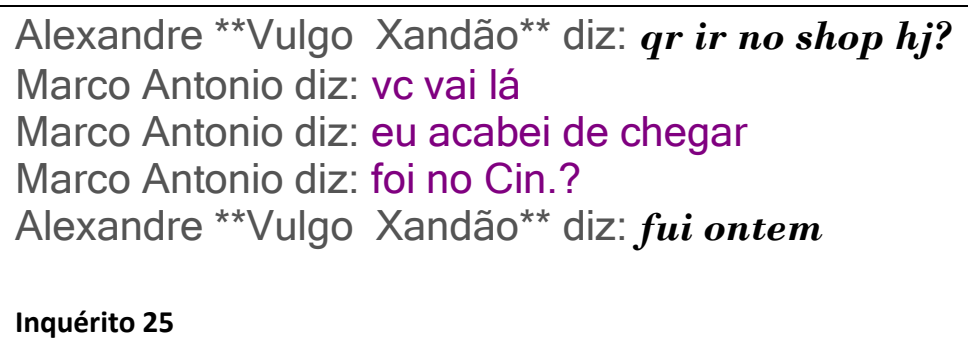

Há poucas ocorrências de "você" em função de sujeito, e a forma "tu" ocorre em apenas dois inquéritos:

(22:09) Helena: Voce ainda não tem PC ? Voce ganharia mais voce reproduzindo.

(22:10) flavio: e isto e verdade 
Jah - Flamengo, vamos ser campeão * * diz: escuta, você torce pra algum time ? danielrodrigues diz: to quase liberto dessa parte e num quero lembrar do q aconteceu ontem...

Inquérito 01

danielrodrigues diz: vou ter q me ausentar pra atender cliente... qdo eu voltar se tu tiver on eu te chamo

Jah - $\quad$ Flamengo, vamos ser campeão *_* diz: auahauahu, tudo bem meu anjo, vai lá **

Inquérito 01

Durante o processo conversacional, os interlocutores estabelecem uma relação dialógica em que ambos adaptam continuamente suas enunciações às necessidades do outro e do contexto em que se desenrolam. Assim, cada ato enunciativo digital influi diretamente no desenvolvimento sucessivo da interação, determinando as futuras ações dos interactantes no evento comunicacional. A conversação deve ser entendida, dessa forma, como um processo interativo em que se preza pela manutenção de acordos firmados por meio de contínuas negociações.

Essas negociações nem sempre envolvem atos de ameaça à face, ou atos eminentemente "negativos", como afirma Kerbrat-Orecchioni (2006), mas, muitas vezes, aparecem situações em que ambos os interactantes se empenham em equilibrar o discurso, harmonizar o diálogo, buscando, por meio de alguns procedimentos próprios do meio, manter o outro em contato.

As conversações digitais ocorridas no $M S N$ são de natureza dialógica, e, há de se lembrar de que, em geral, os interlocutores se conhecem no plano da realidade, o que colabora para que esse tipo de interação se aproxime da conversação face a face prototípica. Assim, encontramos nos inquéritos, não raras vezes, atos valorizadores da face, conforme podemos constatar no exemplo a seguir, onde dois amigos dialogam no ambiente virtual:

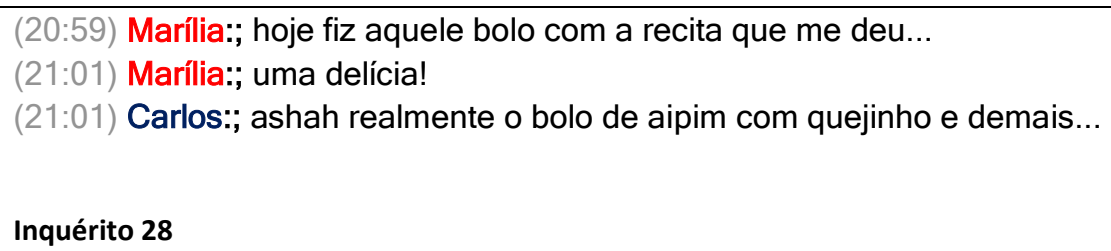


A locutora utiliza um ato de valorização da face, oferecendo um elogio ao interlocutor, que recebe bem "o presente". Esse tipo de ato de fala evidencia o interesse do locutor em preservar a face do outro, propondo uma relação de harmonia e equilíbrio no processo dialógico virtual, deixando claro que não tem interesse em produzir ameaças à face.

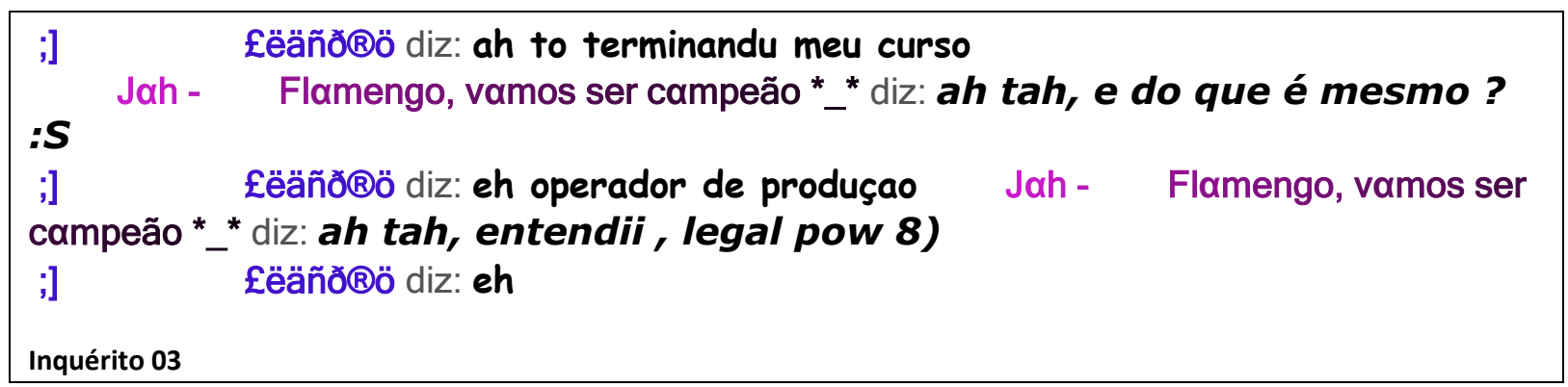

No exemplo acima, a interlocutora Jah utiliza a concordância como estratégia para manter o fluxo conversacional, e lança um elogio ao locutor, que afirma estar finalizando o curso de operador de produção. 0 trecho deixa evidente o interesse em se estabelecer o equilíbrio entre ambos.

Mesmo quando, aparentemente, um ato de possível ameaça é instaurado, percebemos a intenção dos interlocutores em manter as faces neste equilíbrio, por meio de sinais do tipo "kkkkk", "rsrsrs" "ahuahuahuah", que aparecem diversas vezes nas conversações digitais, como formas de "atenuação" ou "abrandamento" do ato enunciativo digital, conforme mostra o exemplo abaixo:

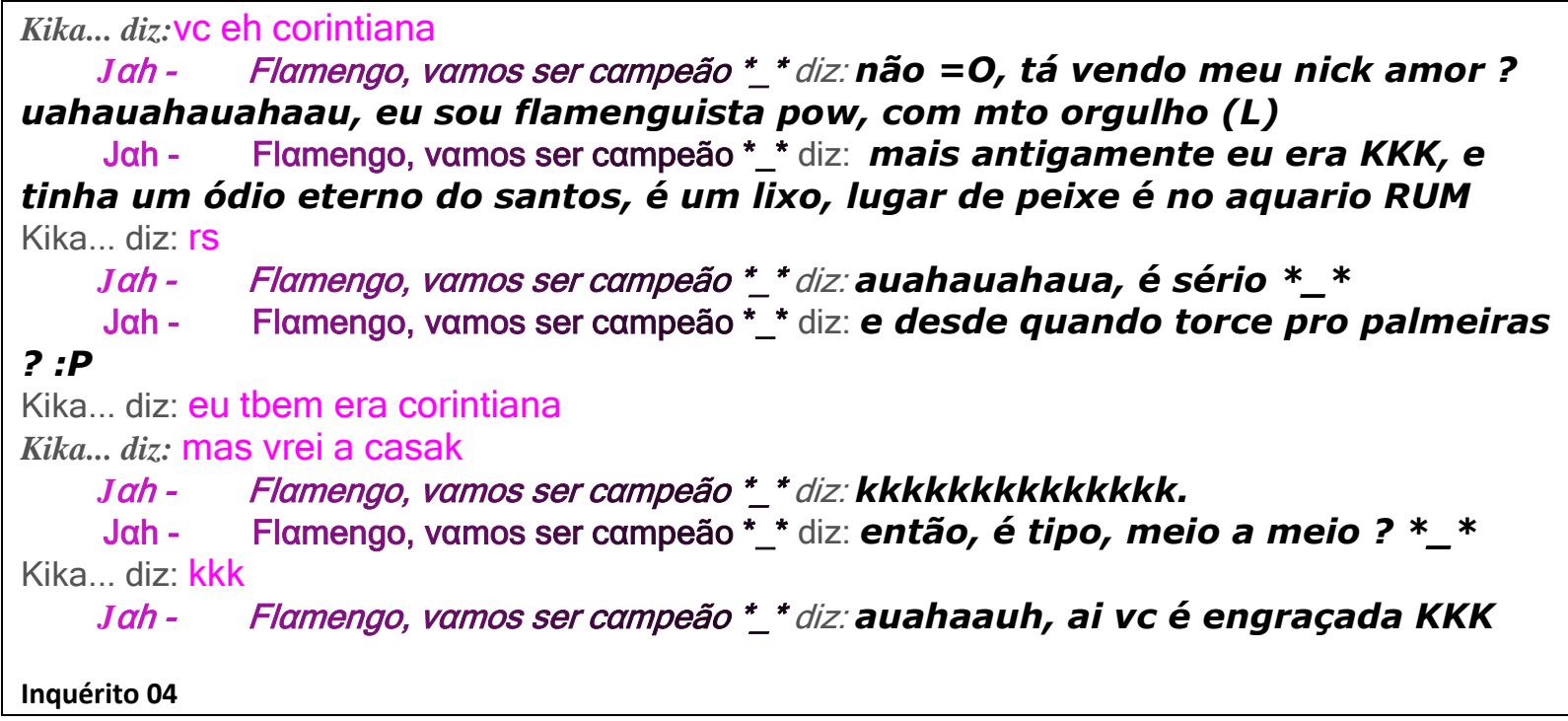


Neste exemplo, Kika parece ameaçar a face positiva de Jah, uma vez que pergunta se ela é Corintiana, mesmo que o nick desta seja claro em sua opção pelo Flamengo, fato que, talvez, não tenha sido percebido pela locutora. A interlocutora responde, prontamente, que não, coloca um emoticon de surpresa " $=0$ ", e, em seguida, emite o sinal de atenuação "uahuahuahauh", reafirmando sua preferência pelo Flamengo.

Kika, ao perceber seu erro, atenua com um "rs" e, logo em seguida, tenta se alinhar, dizendo que também era corintiana, que "virou a casaca". Jah emite um ato em forma de brincadeira, pergunta se ela é meio a meio, as duas riem. O que poderia se desenvolver em um processo de potenciais atos ameaçadores de face, foram mitigados pelos sinais de riso, conforme demonstramos acima.

É interessante salientar que esses sinais aparecem em diversos momentos nos inquéritos e, muitas vezes, como atenuantes para atos enunciativos que, sem apoio na oralidade, poderiam ser interpretados como ameaçadores de face ou mesmo descorteses. No exemplo seguinte, a locutora utiliza deste recurso, procurando atenuar o ato enunciativo ameaçador ao interlocutor, que havia se esquecido de seu aniversário:

\section{Marcos diz: Boa noite!}

Anita feliz diz: boa noite!!!!!!!!!!

Marcos diz: vai trabalhar amanhã?? :0)

Anita feliz diz: cadê o meu presente????????????? Kkkkkkkkkkkkkkkkkkkkk

Anita diz: vo

Marcos diz: aiaiaiaiaiaiai........ axo q eskeci num foi ???? quando foi? Ontem? Vixxx....

Anita diz: tarde demais... :, ( estou deprê rsr srsrsrsrs

Marcos diz: foi mals...kkkkkk e aew.... me fala cadê o livro do Hans que me falou... tá contigi?

Marcos diz: contigo?

Inquérito 28

A utilização dos sinais de riso "kkkkkkk..." leva o interlocutor a inferir que o locutor não deseja ameaçar, necessariamente, sua face, está apenas brincando com um fato, mostrando informalidade, tal como faria em uma situação real, onde, ao invés dos sinais, utilizaria o próprio riso, ou recursos gestuais paralinguísticos, naturais desse tipo de interação. Isso foi prontamente entendido por Marcos, que logo responde "foi mals", e ri, tentando dar por encerrada a questão, e sugere outro tópico menos "ameaçador" para sua face. 
Muitas vezes, um dos interlocutores se ausenta, e é cortês explicitar a necessidade de se ausentar, para que o outro não fique interagindo sozinho. No exemplo seguinte, Helena indica que irá se ausentar, ao que Flávio concorda. Assim que retorna à conversa, cinco minutos após, ela dispara um som para chamar a atenção do interlocutor, e o chama com destaque (Woooooow!):

(20:28) Helena:; ja volto...so um minuto

(20:29) flavio:; tudo bem

(20:34) Helena:; (dispara som de sirene) Wooooow!

(20:35) Helena:; Cheguei, estava copiando umas fotos para o CD

Inquérito 20

Uma conversação cortês exige, naturalmente, uma despedida que não seja "à francesa", ou que não seja interrompida bruscamente, o que denotaria falta de educação. Isso também acontece no meio digital. Estratégias de despedida são utilizadas para "sair do sistema", ou para ficar "offline":

(22:26) flavio: to ficando com sono e com fome

(22:27) Helena: Vai e durma mesmo, aproveite que está mais fresco o tempo,comer durmir éa melhor coisa da vida.

(22:27) flavio: vou embora boa noite fica com deus

(22:28) Helena: boa noite fique com Deus tambem

(22:28) flavio: tchau

(22:28) Helena: thau

Inquérito 22

São comuns despedidas com as fórmulas convencionais: "tchau", "beijos", até as mais informais como "fui", usada pelos mais jovens:

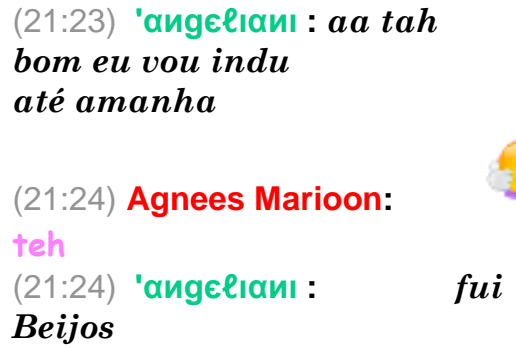




\subsection{0 uso das estratégias de cortesia nas conversações digitais.}

Apesar de, nas relações digitais aqui analisadas, haver um tentativa constante de neutralizar as hostilidades por partes de ambos interlocutores, existem algum momentos de tensão dialógica, no qual notamos atos de fala potencialmente ameaçadores de face, que tendem a ser reparados ou atenuados durante o processo interacional, dependendo da intenção dos interactantes.

Tomemos por base, nesta análise, os inquéritos 26 e 27, em que os interlocutores são brasileiros, paulistas, moradores da Baixada Santista, com idade entre 17 e 27 anos, usuários assíduos do ambiente digital do MSN, sendo 2 homens e uma mulher, todos estudantes universitários e se conhecem pessoalmente.

Jen Jen e Marco Antonio são os interlocutores do inquérito 26. Ambos são colegas de classe de um curso universitário de Direito, e estão de férias. A conversa se inicia com um cumprimento habitual ("oi"), trocado por ambos, e, em seguida, dá-se a progressão do diálogo, que analisamos abaixo:

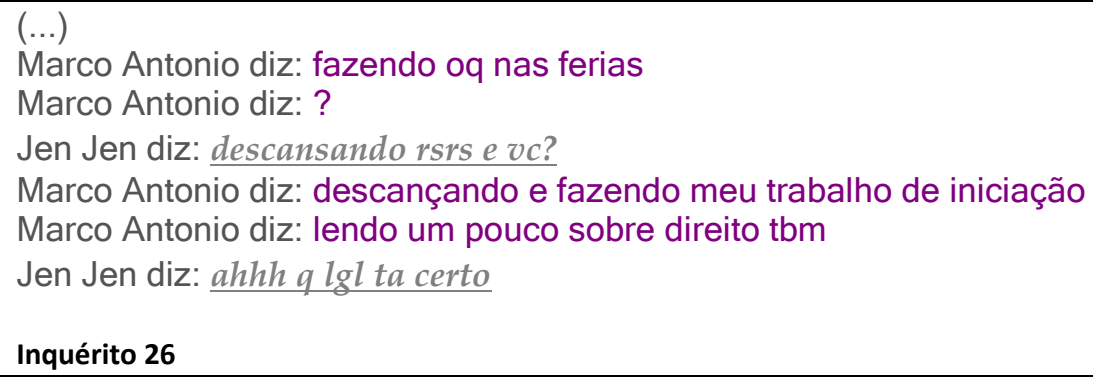

Marco Antonio é direto, ameaçando a face negativa da interlocutora ao questionar o que ela está fazendo durante o período de férias. Jen Jen responde, evasivamente, dizendo que está descansando, e aproveita para perguntar, de maneira direta, o que Marco está fazendo também, retornando a ameaça à face para ele, que responde, em seguida, com dois atos enunciativos. Pela resposta dada, Marco deixa evidente sua intenção no diálogo, que é expor largamente suas próprias atividades de férias, e desencadear um diálogo, tendo como tópico discursivo os estudos. Jen Jen, no entanto, tenta finalizar o tópico com a expressão "ahhh q Igl ta certo". 
Pela progressão do diálogo, porém, percebemos que Marco não desiste de impor este tópico:

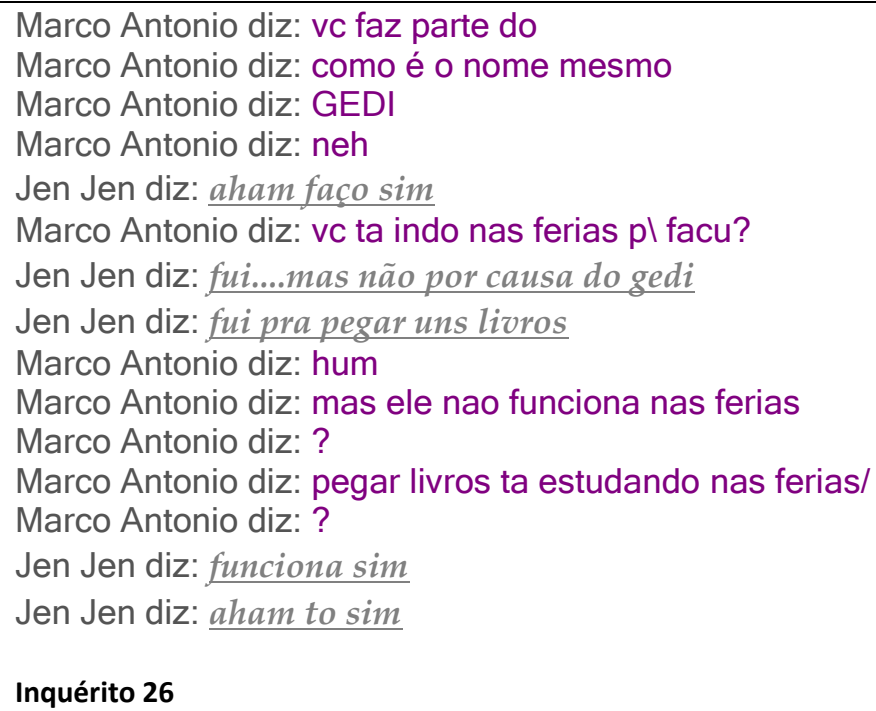

Além de insistir no tópico, Marco, intencionalmente ou não, enuncia um ato de ameaça às faces (positiva e negativa) da estudante, quando questiona a veracidade da informação apresentada por ela, mesmo que de maneira indireta (off record). A colega diz que foi à faculdade no GEDI (Grupo de Estudos em Direito) para pegar livros, e Marco, diz que o GEDI não funciona no período das férias, instaurando a dúvida. Esse ato enunciativo representa uma ameaça à face positiva (imagem de pessoa que fala a verdade, que não mente - imagem social), quanto a negativa (possibilidade de não ter mesmo ido à faculdade - território).

Tentando restaurar o equilíbrio conversacional, imediatamente tenta utilizar um ato de reparação, desviando o foco de sua ameaça anterior, perguntando se ela está estudando nas férias. Jen Jen responde em dois atos enunciativos, dizendo, enfaticamente, que o GEDI "funciona sim" e afirmando que estava "sim" estudando nas férias.

O uso da sigla (GEDI) na conversação faz parte da estratégia de cortesia positiva, a estratégia de número quatro (Brown\&Levinson), em que se busca usar marcas de identidades no grupo. O uso de termos jurídicos e técnicos aqui também evidencia essa estratégia. No trecho que segue, há a utilização do termo "cc", ou "código civil" como marca de identidade do grupo: 
Marco Antonio diz: mas qual livro vc usa

Marco Antonio diz: vc adoou

Marco Antonio diz: p\ sí

Jen Jen diz: o cc anotado dela

Marco Antonio diz: nao tenho código anotado

Marco Antonio diz: eu uso a lei genuina mesmo

Jen Jen diz: é bom tbm

Inquérito 26

Nesse momento do diálogo, Marco questiona qual o livro jurídico utilizado como referência pela interlocutora, e ameaça a face novamente ao discordar do tipo de obra escolhida pela colega. Jen Jen utiliza-se de estratégia de cortesia ao evitar a discordância e buscar concordância - estratégias 05 e 06, ao dizer "é bom também". Marco se esforça para manter o tópico desejado:

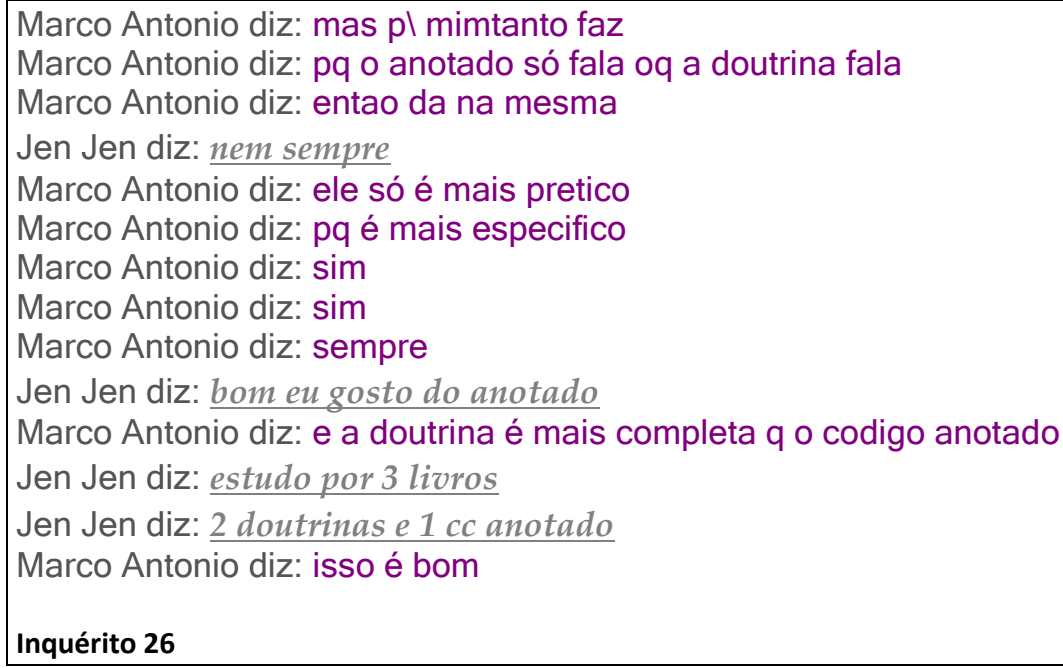

Desta vez, quem ameaça a face é Jen Jen, discordando de Marco no início do exemplo anterior. $\mathrm{O}$ ato enunciativo aponta para a face positiva de Marco, ou seja, sua aceitabilidade e veracidade nas informações concedidas. Ao enunciar "nem sempre", Jen Jen provoca uma "revolta" ilocucionária em Marco, que, ao ter sua face positiva ameaçada, pela não concordância da colega, reafirma duas vezes "sim", e uma vez "sempre".

Esse é um ponto importante na interação, uma vez que os próximos atos decidirão se a conversa partirá para a descortesia, por meio de ironias e agressividade verbal, ou tomará o rumo das atenuações e reparações, mitigando os efeitos negativos do conflito instaurado. 
Ao perceber que a negociação não estava indo bem, Jen Jen utiliza um processo de salva-imagem e diz "bom, eu gosto do anotado". Ao afirmar isso, na verdade, ela está dizendo que, independente da opinião do colega, ela continua mantendo sua posição inicial ao usar o código anotado.

Marco insiste e diz que o livro usado por ele é mais completo que o código anotado. A colega, na tentativa de buscar concordância com o interlocutor, tendo a cortesia por estratégia maior, diz que estuda por três livros, sendo duas doutrinas - o mesmo que o colega utiliza - e um código anotado. O colega, por sua vez, sente-se "vitorioso" e finaliza o tópico com um "isso é bom". A negociação terminou, portanto, com ajustes no discursos de ambos, para que chegassem a um acordo.

O diálogo entre os dois continua, entre ameaças e atenuações, sem que se mude o tópico, e é Jen Jen quem finaliza a conversa:

Jen Jen diz: bom to saindu

Jen Jen diz: $t+$

Marco Antonio diz: xau

Inquérito 26

No inquérito 27, Marco Antonio conversa com um interlocutor de nick exótico, "[b][c=64] $\varnothing \varnothing \times x X||-=\mid$ ka $|=-| \mid X x \times \varnothing \varnothing[/ c][/ b] "$, doravante representado por INT2, para facilitar o fluxo de leitura. No trecho apresentado em seguida, o tópico conversacional gira em torno de trabalhos desenvolvidos nos projetos de iniciação científica, mas um subtópico (a competência de Marco) perpassa a interação, causando um efeito interacional interessante. Observemos:

Marco Antonio diz: eu quero publicar o trabalho

Marco Antonio diz: vc vai tentar a bolsa de iniciação

$[b][c=64] \varnothing \varnothing \times x X \|=\mid$ ka $\mid=-\| X x \times \varnothing \varnothing[/ c][/ b]$ diz: eu só quero a bolsa

$[b][c=64] \varnothing \varnothing \times x X \|==$ ka $\mid=-\| X x \times \varnothing \varnothing[/ c][/ b]$ diz: e quero fazer algo como um "+cc"

$[b][c=64] \varnothing \varnothing \times x X \|=\mid$ ka $\mid=-\| X x \times \varnothing \varnothing[/ c][/ b]$ diz: mas ainda nada

$[\mathrm{b}][\mathrm{c}=64] \varnothing \varnothing \times x \mathrm{X} \|==$ ka $\mid=-\| \mathrm{Xx} \times \varnothing \varnothing[/ \mathrm{c}][/ \mathrm{b}] \mathrm{diz}:\urcorner$

Marco Antonio diz: hum

Marco Antonio diz: quero publicar

Marco Antonio diz: tbm

Marco Antonio diz: acho q sou mais ambicioso

Marco Antonio diz: rsrsrsrsrsrsr

$[b][c=64] \varnothing \varnothing \times x X \|=\mid$ ka $\mid=-\| X x \times \varnothing \varnothing[/ c][/ b]$ diz: huaeuhauehua 


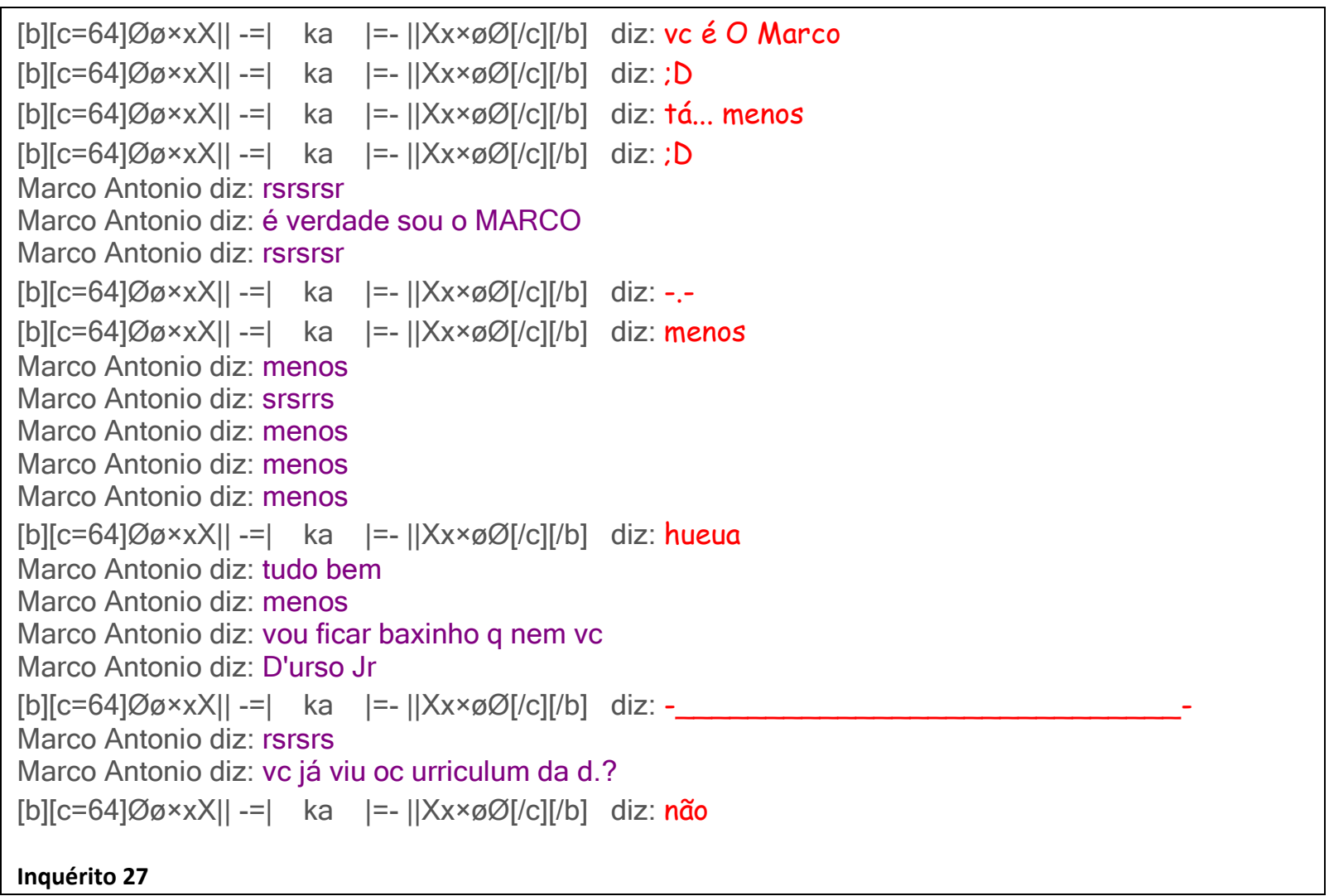

Marco e seu interlocutor conversam sobre o projeto de pesquisa que desencadeará em possível bolsa de estudos. INT2 quer fazer um "tcc" e ganhar a bolsa, ao passo que Marco quer ir além, publicando seu trabalho. A esta altura do diálogo, Marco emite um ato enunciativo - "acho que sou mais ambicioso" - que pressupõe duas interpretações possíveis:

a) um dispositivo indireto para que sua face positiva seja enaltecida de alguma forma por INT2.

b) Um ato de ameaça à face de INT2, uma vez que indiretamente está dizendo que este não tem ambições maiores, ou "pensa pequeno".

Após um momento de risos por parte de ambos, INT2 satisfaz o desejo interacional de Marco, optando, ao menos dentro da conversação, pela primeira interpretação, dizendo "vc é O Marco" -, tecendo desta forma, um elogio direto, oferecendo um "presente" ao interlocutor (estratégia positiva 15) e, ao mesmo tempo, acionando a estratégia 8 - fazer brincadeiras. Marco fica satisfeito com o "presente" e reafirma, num movimento de autoafirmação, "é verdade sou o MARCO". 
Imediatamente, após a auto-afirmação de Marco, INT2 diz "menos", numa tentativa de desinflar o ego do interlocutor. Marco, no entanto, repetindo a palavra "menos", acaba por ameaçar a face positiva de INT2, ao dizer que, de tanto falar "menos", ficará baixinho como o colega.

A reação de INT2 foi enfática, ao usar um emoticon (-_-) que denota "estou apático, foi sem graça", de maneira extendida (-). Para amenizar este ato de ameaça à face, Marco decide não responder ao emoticon e passa a outro tópico imediatamente.

\subsection{Descortesia verbal nas conversações digitais}

Somente um dos inquéritos analisados apresentou atos de descortesia verbal explicitamente. O inquérito 29 revela um diálogo entre duas mulheres, na faixa dos 21 a 30 anos, que discutiram, por um breve período de tempo, no ambiente virtual:

Márcia diz: vc ta ai? Ta online???????????

Marcela diz: Tô sim... e muito raiva de vc... sua INGRATA!

Márcia diz: ???

Márcia diz:???? eu é quem levo a culpa e eu que sou ingrata!!!!! vc n disse pra ele q ela ia ta lá?

Márcia diz: $\approx$ eU SAI DE LA COM TANTA RAIVA DE VC Q NEM SEI PQ AINDA TO AQUI TC COM VC

Marcela diz: vc nao merece o Carlinho ele e muiuto bom..... a Sophia ama ele.... eu disse!!!!!!!!!

Márcia diz: NAUM V PERDE MEU TEMPO COM VC... DEMONOSTROU SER FALSA E

BARRAKERA.... FUIIIIIIIIIIII

Márcia está offline

Marcela diz: ....espera ai..... sua besta.... isso naum pode ficar assim

Inquérito 29

O diálogo deixa explícitos os atos de agressividade verbal por parte dos atos enunciativos de Marcela, que demonstra sua "raiva" por meio de letras em caixa alta, emoticon e palavras agresssivas (ingrata, falsa, barraqueira).

Não se trata da agressividade por "tomada de turno" de maneira abrupta, porque o ambiente virtual não oferece essa possibilidade, uma vez que os AEDs são constituídos de acordo com a intenção dos interlocutores. A agressividade, aqui, fica por conta dos recursos lexicais, tipográficos e visuais. 
A conversação é, abruptamente, interrompida por Márcia, que fica "offline", após ter emitido atos enunciativos agressivos, ameaçando a face positiva de Marcela, que, por sua vez, ainda tentou manter contato, sem sucesso, pois seu último AED não foi recebido pela interlocutora.

\subsection{Considerações sobre a "Cortesia Digital"}

Uma das questões propostas no início deste trabalho versa sobre a possibilidade de se aplicar, no ambiente virtual dialógico, as mesmas estratégias de cortesia e preservação de faces que são próprias da conversação face a face.

Excetuando as estratégias de gestão de turno (assalto ao turno, concessão de turno, tomada brusca, etc), que dependem da voz e da presença física, é possível afirmar que as conversações digitais são regidas pelas mesmas regras da conversação face a face no que tange à cortesia, com alguns acréscimos, necessários para suprir a ausência física e de voz. A tabela seguinte mostra essas adaptações:

\begin{tabular}{|c|c|c|}
\hline Estratégia & Objetivo interacional & Exemplo \\
\hline Repetição de caracteres & $\begin{array}{l}\text { - simular a entonação desejada, } \\
\text { que não é possível por meio da } \\
\text { escrita convencional (oiee, oiii). } \\
\text { - indicar relação de proximidade e } \\
\text { maior solidariedade com o } \\
\text { interlocutor }\end{array}$ & $\begin{array}{l}\text { Oiiiiii } \\
\text { Oieeeee } \\
\text { Aeeeee } \\
\text { amoooooooooorrre }\end{array}$ \\
\hline $\begin{array}{l}\text { Sinalização de riso ou bom } \\
\text { humor com repetição de } \\
\text { caracteres }\end{array}$ & $\begin{array}{l}\text { - atenuar/ abrandar ato } \\
\text { enunciativo digital ameaçador em } \\
\text { potencial. }\end{array}$ & 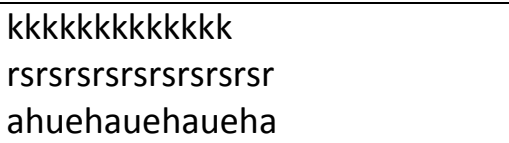 \\
\hline Emoticons & $\begin{array}{l}\text { - demonstração de humor para que } \\
\text { o interlocutor saiba como realizar } \\
\text { os próximos EADs. }\end{array}$ & 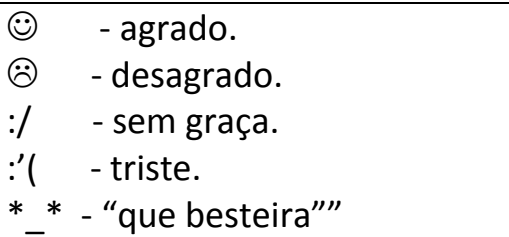 \\
\hline $\begin{array}{l}\text { Uso de caixa alta durante os } \\
\text { diálogos. }\end{array}$ & $\begin{array}{l}\text { - sinal de descortesia verbal digital, } \\
\text { serve para falar alto, gritar, emitir } \\
\text { atos enunciativos agressivos. }\end{array}$ & $\begin{array}{l}\text { NAUM V PERDE MEU TEMPO } \\
\text { COM VC.... }\end{array}$ \\
\hline $\begin{array}{l}\text { Interrupção abrupta do status } \\
\text { (de online para offline) }\end{array}$ & $\begin{array}{l}\text { - implica no mais alto grau de } \\
\text { descortesia possível no ambiente } \\
\text { digital, uma vez que demonstra } \\
\text { desinteresse em manter a } \\
\text { conversação com o outro. Seria o } \\
\text { mesmo que "dar as costas" ou } \\
\text { "virar o rosto" para alguém. }\end{array}$ & $\begin{array}{l}\text { Aline alterou seu status para } \\
\text { offline }\end{array}$ \\
\hline
\end{tabular}


A forma de tratamento padrão das conversações digitais é o vc, e, apesar de não ser muito comum, encontramos a forma você em função de objeto. A forma tu foi encontrada em apenas dois diálogos, indicando proximidade e solidariedade, mas também representando um fato linguístico da região de onde os dados foram coletados (Baixada Santista, onde, segundo Modesto (2006) é comum o uso desta forma em situações informais):

danielrodrigues diz: tu acredita q meu chefe me ligou agora pra me dar bronca danielrodrigues diz: já foram falar merda pra ele danielrodrigues diz: ai q raiva :@

Inquérito 01

Conforme buscamos demonstrar ao longo deste trabalho, a conversação digital apresenta um terreno propício para a utilização da cortesia verbal e suas estratégias, uma vez que a oralidade é sua marca fundamental e a dialogicidade uma condição essencial.

O fato de os interlocutores não estarem frente a frente fisicamente reforça as possibilidades dos FTA ocorrerem, uma vez que, apesar dos recursos tecnológicos do meio, a escrita é a base para a enunciação, e não se tem pistas de contextualização prototípicas, tais como gestos, olhares, entre outros, que são supridas pelos recursos disponíveis pela escrita via teclado.

O fato de os interlocutores se conhecerem pessoalmente e manterem contato contínuo reforça as tentativas de harmonização interacional, e, quando necessário, o uso da cortesia positiva, e os FTA são naturalmente mitigados com estratégias de reparação. 


\section{CONSIDERAÇÕES FINAIS}

$\mathrm{Na}$ introdução deste trabalho, discutimos os avanços tecnológicos na área da comunicação, discorrendo sobre como a internet tem causado grande impacto na vida do homem, na sociedade. Identificamos a necessidade de se estudar os novos gêneros e novas possibilidades de comunicação que surgem com esse avanço, dentre elas, o que aqui chamamos de "conversação digital".

Postulamos, inicialmente, que a conversação digital se apresenta numa linha tênue entre fala e escrita, pois se trata de um "texto falado por escrito". Isso nos possibilitou dizer, ainda inicialmente, que algumas estratégias conversacionais próprias das interações face a face poderiam ser usadas também no meio digital, acrescentando-se a estas, outras, próprias do meio utilizado.

Partindo dessa premissa, procuramos verificar, ao longo deste trabalho, quais eram as características próprias da conversação digital, analisando as estratégias utilizadas pelos interlocutores para entender e serem entendidos durante a interação mediada pelo computador.

Inicialmente, apresentamos os pressupostos teóricos que nortearam esta pesquisa, ou seja, os fundamentos da Análise da Conversação e sua importância para os estudos ligados à comunicação mediada pelo computador. Consideramos que a Análise da Conversação de base etnometodológica fosse a melhor opção, tendo em vista a vocação empirista e indutiva da proposta de estudo apresentada. Também foram discutidas, nesse capítulo, as relações entre fala e escrita na configuração do gênero "conversação digital".

Os capítulos 2 e 4 foram destinados à apresentação das teorias que serviram de norte para as análises. O capítulo 2 expõe a organização e a configuração conversacional nas interações do tipo face a face, e o capítulo 4 apresenta o quadro teórico da (des)cortesia verbal.

Partindo dos quadros teóricos apresentados, procuramos analisar os inquéritos na tentativa de responder às questões levantadas inicialmente neste trabalho. A primeira delas é relacionada à estrutura organizacional da conversação digital. É possível dizer que esta se 
aproxima muito da conversação face a face, com algumas adaptações, incorporando recursos e funções interacionais que são possíveis por conta das características do meio utilizado - o MSN.

Os comunicadores instantâneos, como o MSN, oferecem a possibilidade de trocas em tempo real, e isso permite que os usuários sintam-se falando por escrito. Nessas conversas por escrito, eles imprimem em seus enunciados marcas da oralidade, deixando clara a intenção de proximidade própria das interações de corpo presente, engajando-se em um discurso coproduzido, fruto de trabalho colaborativo constante, interativo, porém, escrito.

Apesar de conversacional, essa modalidade não se apoia na oralidade, pois sua base é a escrita. Hilgert (2000, p.17), porém, deixa claro que esta "...se afina muito mais com o texto falado prototípico (conversação espontânea, conversação telefônica) do que com o correspondente escrito."

Sendo assim, a conversação digital está envolvida em eventos do tipo social, uma prática inerente ao homem, independente do canal utilizado. Se considerarmos, de acordo com Marcuschi (2005), as condições essenciais para que a conversação ocorra - interação centrada, execução numa identidade temporal, participação de pelo menos dois interactantes, e ao menos uma troca de enunciado -, podemos considerar as interações do MSN na categoria das conversações, pois, segundo vimos,

a) ocorrem em tempo real/sincrônico;

b) há a participação de ao menos dois interlocutores;

c) há troca de enunciados entre os participantes (Marcuschi considera troca ou alternância de turnos, que aqui são os AEDs.);

d) o envolvimento se dá numa interação centrada.

No MSN, a conversação é centrada: há mudanças e alternâncias de tópicos, mas os interlocutores não podem demorar para responder aos atos enunciativos de chamada, pois ambos requerem que suas intervenções sejam prontamente respondidas ou atendidas. $O$ andamento da conversação, como esta se dá em tempo real, é ininterrupto. O resultado dessa interação síncrona está na economia das formas linguísticas escritas, fator importante para manter o ritmo do processo. 
Dentre os meios ou recursos mais comuns estão as reduções de palavras tendo em vista preservar aspectos fonéticos, sempre ligados à oralidade, tais como "bjs" (Beijos) ou "kd vc" (cadê você). Jonsson (1997) entende que o uso destes recursos implique não somente uma simplificação das formas de escrita, mas também a diminuição do tempo de decodificação na leitura, fazendo com que os usuários familiarizados aproximem-se ainda mais da velocidade da fala.

\section{O turno conversacional na conversação digital: Ato Enunciativo Digital}

Procuramos analisar os dados na tentativa de responder à questão apresentada inicialmente: "existe turno conversacional na conversação digital?" Ao proceder às análises, um primeiro aspecto fundamental deste gênero nos chamou a atenção: a descoberta de que a regra "fala um por vez", considerada por Marcuschi como o principal mecanismo da conversação, não se fundamenta no plano virtual.

Na Conversação Digital não há uma alternância nos papéis de falante e ouvinte, pois ambos os interlocutores interagem simultaneamente no ambiente virtual. Assim, não se pode considerar a troca de falantes como um fator relevante para a instauração do processo conversacional, pois não há a necessidade de passagens ou assaltos aos turnos.

Nas interações desse tipo, portanto, os atos de fala não seguem o roteiro esperado pela regra padrão da conversação, ou seja, o sistema A-B-A-B. Existe o ato de fala, mas não pode ser considerado um "turno" no sentido tradicionalmente encontrado, pois essa regra é plausível apenas em se tratando de conversação face a face convencional, quando a sobreposição das vozes (canal) torna impossível a intercompreensão entre os interlocutores.

Verificamos, então, que, nas conversações digitais, os interlocutores produzem atos enunciativos, uma vez que estes não são atos de fala, pois correspondem à atualização da língua numa situação de interação por meio da escrita, dependente do interlocutor para se desenvolver e não apoiados na fala/oralidade.

Por não representar um turno, e por se tratar de um ambiente digital, chamamos esse ato de Ato Enunciativo Digital (AED). Definimos o AED como uma ação de natureza linguística, verbal e interativa, capaz de produzir efeitos pragmáticos no interlocutor, a 
ponto de fazê-lo interagir em tempo real, por meio de outro AED, acionando assim o processo conversacional digital.

Na conversação digital, ambos os interlocutores disparam AEDs, e ambos respondem aos AEDs disparados, sem a necessidade de espera pela "vez" de falar. Também não é necessário "sustentar" a vez de falar, uma vez que ambos podem emitir seus AEDs simultaneamente, e serão respondidos, à medida que forem lendo os enunciados disparados.

O papel do AED é promover o contato, chamar o outro à participação. Está a serviço da interação e da interatividade no plano virtual Quanto à extensão, podemos dizer que os AEDs não ultrapassam a marca das três linhas de texto. Em todas as conversações analisadas, a maior parte dos enunciados ficou restrito a uma ou duas linhas.

Quanto à constituição formal, postulamos que os AEDs têm uma concepção oral, mas o meio é gráfico, e o canal de comunicação é escrito, possuindo, portanto, características inerentes aos planos da oralidade (versatilidade, sincronicidade, rapidez) e da escrita (registro formal dos eventos), concomitantemente.

Verificamos que os AEDs podem ser acionados no momento da conversação digital, independente de outros AEDs lançados pelo interlocutor. A centração é garantida por meio do tópico discursivo. Em outras palavras, apesar de vários AEDs serem lançados simultaneamente, só haverá conversação digital se os interlocutores atenderem aos AEDs de seus parceiros, por meio de atos do tipo nuclear ou inserido.

Quanto à tipologia, os AEDs se aproximam da classificação de turnos apresentada por Galembeck (1993): há AEDs nucleares, que são aqueles em que os interlocutores desenvolvem os tópicos conversacionais, e os inseridos, que indicam o acompanhamento do fluxo comunicativo na conversa.

\section{O tópico discursivo nas conversações digitais}

Uma primeira constatação durante uma análise inicial dos inquéritos permitiu-nos dizer que a centração é uma característica da conversação face a face extensível à digital, uma vez que a topicalidade organiza o discurso, permitindo a continuidade deste. 
A conversação digital não se difere, neste aspecto, da conversação prototípica, uma vez que, na maior parte das vezes, o tópico possui uma articulação de proximidade em relação à linha discursiva, propondo informações novas conforme o desenvolvimento da conversação. A conversação digital apresenta, portanto, uma organização de progressão discursiva, não sendo aleatória ou caótica.

Logo após as primeiras análises, verificamos que, na ausência da organização conversacional por turnos de fala, o tópico discursivo representava o fio condutor dos diálogos. Assim, não é exagero dizer que, no contexto da conversação digital, o tópico discursivo, pode ser considerado o núcleo da interação.

É por meio dele que a conversação digital se estabelece, após o primeiro contato dos interlocutores, geralmente iniciado por um cumprimento. Na maioria das conversações digitais, encontramos aspectos idênticos aos da conversação face a face, com a exceção de que, no contexto digital, os interlocutores podem conversar sobre mais de um assunto "ao mesmo tempo", por meio do acionamento de vários AEDs em sequência.

Isso nos levou a pensar na possibilidade de tratar esse fenômeno como "pareamento de tópicos discursivos", algo que seria improvável na interação face a face. Isso só é possível na conversação digital porque os interlocutores escrevem seus atos enunciativos, o que dá margem a inserções conjuntas, que vão sendo respondidas na medida em que a conversação flui. Esse pareamento de tópicos poderia ser assim representado no quadro tópico:

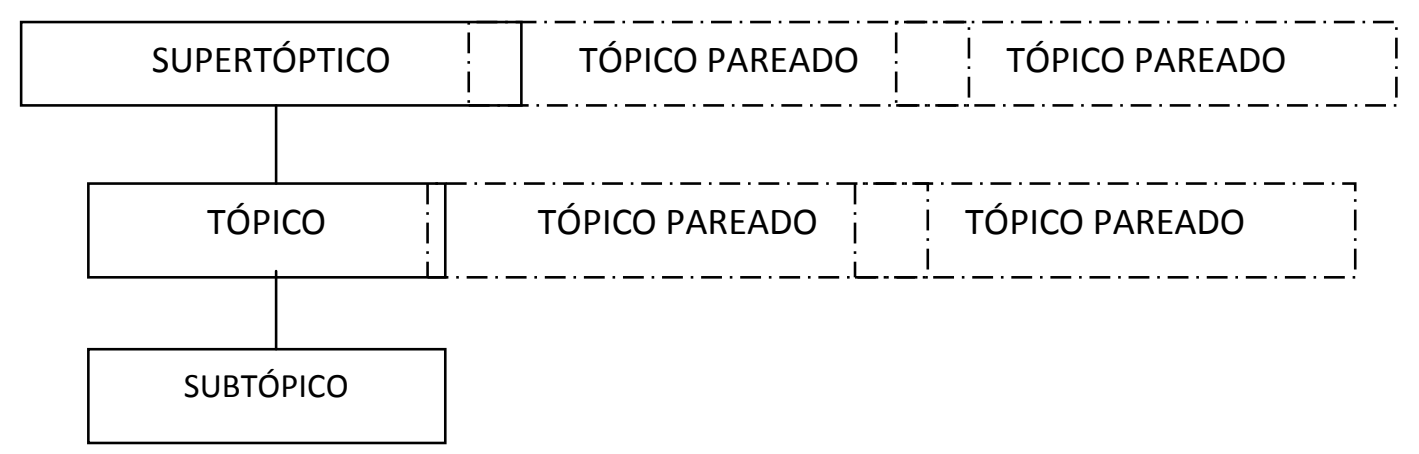

Figura 14 . Quadro Tópico da Conversação Digital.

Os tópicos pareados ficam à margem do assunto central, mas possuem importância no evento conversacional porque também são "interagidos” durante o processo. 


\section{Marcadores conversacionais}

Umas das características mais marcantes da conversação digital é o uso intenso de marcadores conversacionais. Isso evidencia o caráter dinâmico e dialógico desse tipo de interação. Encontramos marcadores próprios da oralidade, bem como alguns que são de uso exclusivo das conversações digitais, e geralmente são adaptações de situações da interação face a face.

Quanto aos marcadores convencionais, é importante ressaltar que, como a noção de turno não se aplica à Conversação Digital, pode-se dizer que os marcadores iniciais e mediais se fundem, uma vez que os atos de fala podem se subdividir em diversos AEDs.

A conversação digital segue, em geral, a tendência da interação face a face: dinâmica, rápida, coerente, porém muitas vezes segmentada. Os AEDs geralmente não são extensos, pois a falta de atividade por parte de um dos interactantes pode ser interpretada como descaso ou falta de atenção por parte do outro. Daí a necessidade de os interlocutores "quebrarem" suas sequências de "fala" com acionamento de "enteres", gerando diversos AEDs que remetem a um mesmo enunciado.

Sendo assim, a maioria dos AEDs é curta e, quando se precisa prolongar o enunciado, os marcadores ideacionais são utilizados para dar conta dessa necessidade, servindo de aviso ao interlocutor para que espere o outro terminar seu enunciado ou mesmo que preste atenção ao que está sendo dito.

Os marcadores verbais lexicalizados são representados como na conversação face a face (só que por meio da escrita), enquanto que os prosódicos e não - linguísticos são representados por vários elementos gráficos, como reticências, onomatopeias ou os emoticons (expressões iconográficas que representam emoções humanas ligadas ao humor (como por exemplo: $\%$ ).

Elencamos a seguir os marcadores conversacionais de uso exclusivo no ambiente virtual, encontrados nos inquéritos analisados: 
a) Reticências (...) - Representação prosódica, que indica pausas, curtas ou longas. Parece ter uso para hesitações, finalizações e até em progressão de tópico, indicando que um EAD será seguido de outro, que o completará.

b) Onomatopeias (ae... ae... ae..., uffa, haha, em) - Na interação face a face, é comum as palavras serem acompanhadas de pequenos gestos ou de tom de voz mais intimista, representado na interação virtual pela expressão lexical do falante com o uso de onomatopeia, por meio da imitação do som e variação da voz. Na interação digital, essas imitações se lexicalizam na digitação de diversas maneiras, conforme vimos nos exemplos apresentados.

c) emoticons - Os emoticons são figuras iconográficas que representam expressões faciais, e visam a demonstrar emotividade e humor dos interlocutores no momento da conversação. A expressão é derivada do inglês emotions-ícons, ou ícones de emoção. 0 MSN Live Messanger possui alguns emoticons disponíveis por padrão. Os usuários, no entanto, podem se valer da digitação associada de letras, números e símbolos para criar outros emoticons. Estes podem representar emoções (alegria, raiva, repulsa/nojo, medo, desejo, espanto), intenções e ações (preguiça, cansaço, beijar, ir à praia, gargalhar, piscar olho), modos de ser e estar (loucura, indecisão), entre outros. Os emoticons encontrados em nossos inquéritos encontram-se na tabela 8, p. 102. A tabela abaixo exibe alguns exemplos:

\begin{tabular}{|l|l|l|l|}
\hline$:)$ & Sorriso, feliz & $=($ & Triste \\
\hline =D & Sorriso enorme & $=\mid$ & Indeciso, incerto \\
\hline$-{ }_{-}$ & Tedioso ou “não gostei” & $: 0)$ & meigo, palhaço \\
\hline
\end{tabular}

Tabela 11: Exemplos de Emoticons no corpus

d) a marcação das interrogativas em um AED isolado (?) - Muitas vezes, o interlocutor pode considerar o isolamento do sinal de pergunta ( ?) como uma estratégia importante para o fluxo da conversa, chamando a atenção para o questionamento feito ao interlocutor. Trata-se de um marcador não linguístico, encontrado em algumas interações. 
e) CAIXA ALTA (uso de maiúsculas) - O uso de maiúsculas remete ao tipo de marcadores não linguísticos, prosódicos, indicando entonações diferenciadas, que podem ser consideradas como "animação" do falante (como por exemplo AHUEHUEHUEHHAHEU) ou raiva, nervoso e descortesia (como por exemplo JÁ DISSE QUE NÃO VOU!!!!). A interpretação correta da utilização das maiúsculas no evento comunicacional digital vai depender da análise contextual que, no ambiente virtual, depende do tópico discursivo e da forma como os interlocutores encaminham o diálogo. O uso da caixa alta pode indicar, ao contrário do apresentado anteriormente, expressão de alegria, ansiedade, contentamento. A repetição de caracteres e o final representando o riso evidencia esse "estado de ânimo" do locutor.

\section{Hesitações e Repetições}

Antes de iniciar a análise dos processos de correção nas conversações digitais, consideramos conveniente também verificar alguns procedimentos de formulação no contexto digital. Com relação às hesitações, verificamos que estas são marcadas basicamente por reticências, que indicam pausas, e apontam para o momento da formulação do AED por parte do locutor, evidenciando que, devido à agilidade necessária para estabelecer o contato e dar o feedback, não há muito tempo de fazer a "lapidação" do enunciado, sendo mais eficaz indicar esse momento de dúvida diante do que se vai falar em seguida, por meio de pausas.

Quanto às repetições, estas não se mostraram produtivas nesse contexto e, portanto, não ocorrem com frequência na conversação digital, sendo mais evidente nos reforços de negação, geralmente ocorrida com estruturas diferentes (não-nem, não, num, não, nunca, etc).

\section{O fator "correção" nas conversações digitais}

Na conversação digital, a ausência da voz e o deslocamento do texto escrito para o plano da oralidade, estabelecendo relação do tipo dialógica, é um fator determinante para que a correção apareça. 
Não há reparos propriamente ditos, uma vez que esta é uma correção de uma infração conversacional e, no plano virtual, não há gestão de turnos, não havendo a necessidade de se realizar esse procedimento.

Os casos de reformulação encontrados nas conversações digitais ficaram restritos às autocorreções propriamente ditas, que representam a tentativa de solucionar problemas retrospectivos de compreensão do enunciado, além de tentar salvar a face de situações ameaçadoras da imagem pública.

Nos inquéritos analisados, ficaram restritos a correções vocabulares com falhas cometidos a partir de erros de digitação. Esses erros são comuns, e são decorrentes da percepção ou impressão que o locutor tem de que está em presença ou sob o olhar do outro, tendo que digitar rapidamente para lançar seus AEDs.

Um aspecto importante e delimitador para a autocorreção é que nas conversações digitais, a ausência de turnos permite que o locutor faça suas autocorreções em outro AED, uma vez que, se notar o "erro" no momento da formulação do ato enunciativo, corrige antes de o emitir. Sendo assim, os casos de autocorreção encontrados foram emitidos em AEDs isolados, precedidos de um asterisco, sinal evidente e próprio da correção no ambiente virtual.

\section{Formas de tratamento nas conversações digitais}

A forma de tratamento mais utilizada no contexto digital é, por excelência, o " $v c^{\text {", }}$ usada pela maioria dos interlocutores nas interações. A forma "tu" foi encontrada em apenas dois diálogos, indicando proximidade e solidariedade, mas também representando um fato linguístico da região de onde os dados foram coletados (Baixada Santista, onde, segundo Modesto (2006), é comum o uso desta forma em situações informais)

Quanto às formas de tratamento convencionais, é natural que, em qualquer diálogo, há que se observar um estatuto de comunicação de proximidade ou distância social, poder ou solidariedade, para daí se proceder à escolha das formas adequadas. No corpus coletado, as interações acontecem entre pessoas com grande proximidade, amigos e colegas de 
estudo, além de familiares, o que resultou na utilização massiva de "vc" e, raras vezes, "você" e "tu".

A utilização da forma vc como referência direta ao interlocutor constitui-se numa variante lexical de "você". Acreditamos que esse uso foi instaurado certamente em decorrência da velocidade com que as informações são processadas virtualmente, principalmente quando há interação simultânea com diversos meios para dinamizar a conversa.

\section{Estratégias de cortesia verbal e preservação de faces na conversação digital}

Conforme buscamos demonstrar ao longo deste trabalho, a conversação digital apresenta um terreno propício para a utilização da cortesia verbal e suas estratégias, uma vez que a oralidade é sua marca fundamental e a dialogicidade uma condição essencial.

Verificamos algumas características próprias das conversações, em geral, e outras próprias das conversações digitais. Assim como nas conversações naturais, por exemplo, as pessoas, nas conversações digitais, iniciam o contato cumprimentando-se, variando a forma de acordo com o grau de amizade e/ou intimidade. As fórmulas de saudação são iguais às que usamos regularmente em nossas relações interpessoais no ambiente real.

As repetições de letras são utilizadas para simular a entonação desejada, que não é possível por meio da escrita convencional (oiee, oiii). Esse procedimento também indica uma relação de proximidade e maior solidariedade com o interlocutor, podendo ser considerado um aspecto da cortesia verbal digital.

O fato de os interlocutores não estarem frente a frente fisicamente reforça as possibilidades de ocorrem os atos de ameaça à face - FTA, pois, apesar de apresentar muitos recursos tecnológicos, a base do programa de comunicação é a escrita, e não se tem pistas de contextualização prototípicas, tais como gestos, olhares, entre outros, que são supridas pelos recursos disponíveis pela escrita via teclado (repetições de letras, emoticons, etc).

Há uma busca constante pela harmonização interacional, principalmente porque os interlocutores, geralmente, se conhecem no plano real. Durante o processo, verificamos 
que, quando necessário, o uso da cortesia positiva, e os FTA são naturalmente mitigados com estratégias de reparação.

Verificamos que, durante o processo conversacional, os interlocutores estabelecem uma relação dialógica em que ambos adaptam continuamente suas enunciações às necessidades do outro e do contexto em que se desenrolam. Assim, cada ato enunciativo digital influi diretamente no desenvolvimento sucessivo da interação, determinando as futuras ações dos interactantes no evento comunicacional, num processo interativo em que se preza pela manutenção de acordos firmados por meio de contínuas negociações.

Essas negociações, nem sempre, envolvem atos de ameaça à face, ou atos eminentemente "negativos", como afirma Kerbrat-Orecchioni (2006), mas muitas vezes aparecem situações em que ambos os interactantes se empenham em equilibrar o discurso, harmonizar o diálogo, buscando, por meio de alguns procedimentos próprios do meio, manter o outro em contato.

Mesmo quando, aparentemente, um ato de possível ameaça é instaurado, percebemos a intenção dos interlocutores em manter as faces neste equilíbrio, por meio de sinais do tipo "kkkkk", "rsrsrs" "ahuahuahuah", que aparecem diversas vezes nas conversações digitais, como formas de "atenuação" ou "abrandamento" do ato enunciativo digital.

Quanto às despedidas, são comuns as fórmulas convencionais: "tchau", "beijos", até as mais informais como "fui", usada pelos mais jovens.

Apesar de, nas relações digitais aqui analisadas, haver um tentativa constante de neutralizar as hostilidades por partes de ambos interlocutores, existem alguns momentos de tensão dialógica, no qual notamos atos de fala potencialmente ameaçadores de face, que tendem a ser reparados ou atenuados durante o processo interacional, dependendo da intenção dos interactantes.

Uma das questões propostas no início deste trabalho versa sobre a possibilidade de se aplicar, no ambiente virtual dialógico, as mesmas estratégias de cortesia e preservação de faces que são próprias da conversação face a face. Nesse sentido, podemos afirmar que, excetuando as estratégias de gestão de turno (assalto ao turno, concessão de turno, tomada 
brusca, etc), que dependem da voz e da presença física, as conversações digitais são regidas pelas mesmas regras da conversação face a face no que tange à cortesia, com alguns acréscimos, necessários para suprir a ausência física e de voz, conforme foram demonstrados na tabela 10 do capítulo anterior, a qual reproduzimos abaixo novamente:

\begin{tabular}{|c|c|c|}
\hline Estratégia & Objetivo interacional & Exemplo \\
\hline Repetição de caracteres & 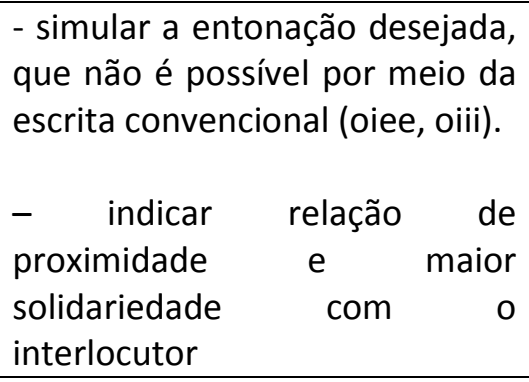 & $\begin{array}{l}\text { Oiiiiii } \\
\text { Oieeeee } \\
\text { Aeeeee } \\
\text { amoooooooooorrrre }\end{array}$ \\
\hline $\begin{array}{l}\text { Sinalização de riso ou bom } \\
\text { humor com repetição de } \\
\text { caracteres }\end{array}$ & $\begin{array}{l}\text { - atenuar/ abrandar ato } \\
\text { enunciativo digital ameaçador } \\
\text { em potencial. }\end{array}$ & 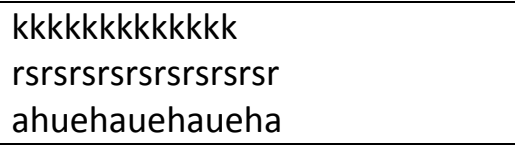 \\
\hline Emoticons & $\begin{array}{l}\text { - demonstração de humor para } \\
\text { que o interlocutor saiba como } \\
\text { realizar os próximos EADs. }\end{array}$ & 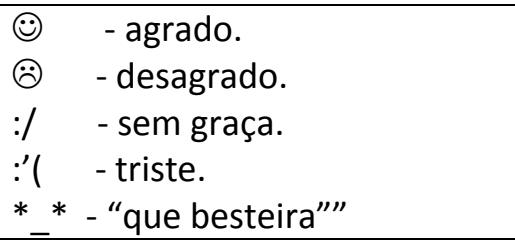 \\
\hline $\begin{array}{l}\text { Uso de caixa alta durante } \\
\text { os diálogos. }\end{array}$ & $\begin{array}{l}\text { - sinal de descortesia verbal } \\
\text { digital, serve para falar alto, } \\
\text { gritar, emitir atos enunciativos } \\
\text { agressivos. }\end{array}$ & $\begin{array}{l}\text { NAUM } \vee \text { PERDE MEU TEMPO } \\
\text { COM VC.... }\end{array}$ \\
\hline $\begin{array}{l}\text { Interrupção } \\
\begin{array}{l}\text { abrupta do } \\
\text { status (de online para } \\
\text { offline) }\end{array}\end{array}$ & $\begin{array}{l}\text { - implica no mais alto grau de } \\
\text { descortesia possível no } \\
\text { ambiente digital, uma vez que } \\
\text { demonstra desinteresse em } \\
\text { manter a conversação com o } \\
\text { outro. Seria o mesmo que "dar } \\
\text { as costas" ou "virar o rosto" } \\
\text { para alguém. }\end{array}$ & $\begin{array}{l}\text { Aline alterou seu status para } \\
\text { offline }\end{array}$ \\
\hline
\end{tabular}

Tabela 12: Estratégias de (Des)cortesia Verbal Digital.

Esperamos que, ao concluir esta etapa da pesquisa, possamos ter contribuído para os estudos na área de comunicação digital, possibilitando um novo caminho para a compreensão dos fenômenos da conversação digital. Sabemos que há inúmeros trabalhos na área de CMC (Comunicação mediada por computador), mas ainda não havia até então uma reflexão sobre os processos dialógicos e organizacionais da conversação vista enquanto um gênero digital. 
Este trabalho, então, soma-se aos outros empreendidos sobre as diversas manifestações comunicativas no meio digital, constituindo-se em mais um referencial que pode vir a explicar processos interacionais nas conversações digitais dialógicas.

Nosso estudo, porém, não esgota as possibilidades de análise dos aspectos aqui estudados. Não verificamos, por exemplo, diferentes níveis de monitoramento dos interlocutores, formalidade e informalidade, diferenças entre faixas etárias e gêneros, entre outros. Isso deixa uma abertura para que futuros estudos possam ser empreendidos, analisando-se outros corpora de gêneros dialógicos, utilizando-se os procedimentos aqui apresentados, além de outros que possam vir a contribuir para delinear essa nova área de estudos linguísticos, a Análise da Conversação Digital. 


\section{BIBLIOGRAFIA}

ANDRADE, M. L. C. V. O. (2008). (Des)cortesia e contestação em interações escritas. In: PRETI, Dino (Org).Cortesia Verbal. São Paulo:Humanitas. pp. 193-214.

- (1990). Contribuição à gramática do português falado: estudo dos marcadores conversacionais então, aí, daí. Dissertação de mestrado. São Paulo: PUC.

AQUINO, Z. G. O. de. (1991). A mudança de tópico no discurso oral dialogado. Dissertação de Mestrado. São Paulo:PUC.

ARAÚJO, Júlio César Rosa de. (2004). A conversa na web: o estudo da transmutação em um gênero digital. In: MARCUSCHI, L.A. \& XAVIER, A.C.S (orgs). Hipertexto e Gêneros Digitais. Rio de Janeiro: Lucerna.

AUSTIN, J. L. (1990). Quando dizer é fazer. Porto Alegre: Artes Médicas.

. (1965). How to do things with words. New York: Oxford University Press.

FERREIRA, Aurélio B. Hollanda (1975). Novo dicionário da língua portuguesa. Rio de Janeiro: Nova Fronteira.

BARROS, Diana Luz Pessoa.(2000). Entre a fala e a escrita: algumas reflexões sobre as posições intermediárias. In: PRETI, D.(org.) Fala e escrita em questão. 2. ed. São Paulo: Humanitas, pp.57-78.

. (1993). Procedimentos de reformulação: a correção. In: PRETI, Dino (org.). Análise de textos orais. São Paulo:FFLCH/USP. pp.129-141

BARROS, Kazue Saito Monteiro (2001). Características organizacionais de aulas pela Internet. In: URBANO, Hudinilson et ali. (orgs). Dino Preti e seus temas: oralidade, literatura, mídia e ensino. São Paulo: Cortez.

BRAIT, Beth. (1993). O processo interacional. In: PRETI, Dino (org.). Análise de textos orais. São Paulo:FFLCH/USP. pp.189-214.

BROWN, Penelope. \& LEVINSON, Stephen C. (1987 [1978]). Politeness: some universals in language use. Cambridge: Cambridge University press.

. (1986). Universals in language usage: politeness phenomena. Cambridge:

Cambridge University Press.

BROWN, G. e YULE, G. (1983). Discourse analysis. Cambridge: Cambridge University Press. 
CASTILHO, A. T. (1989). Para o estudo das unidades discursivas no português falado culto no Brasil. In CASTILHO, A T. (org.) Português falado culto no Brasil. Campinas : UNICAMP. pp. 249-279.

CHAFE, W.L. (1982). Integration and involvement in speaking, writing, and oral literature. In: TANNEN, D. (ed). Oral and written discourse. Norwood, NJ:Ablex.

CHAVES, Gilda Maria Monteiro. (2001). Interação On-line: Análise de Interações em Salas de Chat. In: Vera Lúcia Menezez PAIVA (Org.). Interação e Aprendizagem em Ambiente Virtual. Belo Horizonte, FALE- UFMG. pp. 37-73.

COULON, Alain. (1995). Etnometodologia. Petrópolis: Vozes

CRESCITELLI, M.F.C. (1997). Disfluência conversacional em falantes cultos (Projeto NURC/SP). Tese de Doutorado. São Paulo:FFLCH/USP.

CRYSTAL, David.(2005). The scope of Internet Linguistics. Artigo disponibilizado on-line para o encontro da Associação Americana para o Avanço da Ciência. Fevereiro de 2005. [http://www.davidcrystal.com/] Acesso em 20/09/2006.

. (2002). El lenguage e Internet. Madrid: Cambridge University Press.

(1996). To surf or not to surf: this is the question. The Ben Bowen Thomas Lecture. Bodelwiddan Castle. [http://www.davidcrystal.com/DC_articles/Internet9.pdf] Acesso em 20/09/2006.

ERICKSON, Thomas. (2000). Making Sense of Computer-mediated Communication (CMC): Conversations as genres, CMC Systems as Genre Ecologies. In the Proceedings of the ThirtyThird Hawaii International Conference on Systems Science. (ed. J. F. Nunamaker, Jr. R. H. Sprague, Jr.), Hawaii:IEEE Press. [ http://www.pliant.org/personal/Tom_Erickson/] Acesso em 27/11/2006.

(1997). Social Interaction on the Net: Virtual Community as participatory Genre. (Publicado no Proceedings of the Thirtieth Hawaii International Conference on System Science). Vol. VI. Hawaii:IEEE Press. 13-21. http://www.pliant.org/personal/Tom_Erickson/VC_as_Genre.html] Acesso em 27/11/2006.

FÁVERO, Leonor Lopes; ANDRADE, Maria Lúcia C.V.O.; AQUINO, Zilda G.O. (2007). Oralidade e escrita: perspectiva para o ensino da língua materna. 6a Ed. São Paulo: Cortez.

. (1999). A correção no texto falado: tipos, funções e marcas. In: NEVES, Maria Helena de Moura (org). Gramática do Português falado. Vol. VII: Novos estudos. São Paulo: HUmanitas/Fapesp, pp.53-76 
FÁVERO, Leonor Lopes. (1993). O Tópico Discursivo. In: PRETI, Dino (org.). Análise de textos orais. São Paulo:FFLCH/USP. pp.33-54

FERNANDES, Raúl Cesar Gouveia (2001). Amor e cortesia na literatura medieval. Notandum. Revista Semestral Internacional de Estudios Académicos- Ano IV. NVII. <http://www.hottopos.com/notand7/raul.htm> acesso em setembro de 2011.

FIRMINO, Júlio César Ferreira. (2005). Formas associativas existentes nas salas de batepapo.in: ARAÚJO, Júlio César e BIASI-RODRIGUES, Bernadete. (Org.) Interação na Internet. Novas formas de usar a linguagem. Rio de Janeiro: Lucerna. p.39-47

FIORIN, José Luiz (2005). As astúcias da enunciação: as categorias de pessoa, espaço e tempo. São Paulo: Ática.

GALLI, Fernanda Correa Silveira. (2004). Linguagem da Internet: um meio de comunicação global. In: MARCUSCHI, L.A. \& XAVIER, A.C.S (orgs). Hipertexto e Gêneros Digitais. Rio de Janeiro: Lucerna.

GALEMBECK, Paulo de Tarso. (2010). Processos de Construção de textos falados e escritos. XIV Congresso Nacional de Linguística e Filologia. Círculo Fluminense de Estudos Filológicos e Linguísticos. <http://www.filologia.org.br/xiv_cnlf/tomo_2/1565-1577.pdf> pp. 1556 - 1577. Acesso em maio/2011.

. (2008). Polidez e preservação da face na fala de universitários. In: PRETI, D. (Org.). Cortesia verbal. São Paulo. Humanitas/FFLCH/USP, pp. 323-344.

. (1999). Preservação da face e manifestação de opiniões: um caso de jogo duplo. In: PRETI, Dino (Org.). O discurso oral culto. São Paulo: Humanitas.

. (1993). O turno conversacional. In: PRETI, Dino (org.). Análise de textos orais. São Paulo:FFLCH/USP. pp.55-79

GALEMBECK, Paulo de Tarso; COSTA, Nonalíssia Silva da. (2009). Alternância e participação: a distribuição de turnos na interação simétrica . In: CELLI - COLÓQUIO DE ESTUDOS LINGUÍSTICOS E LITERÁRIOS. 3, 2009, Maringá. pp. 1937-1944.

GARCEZ, Pedro. M.(2008). Entrevista concedida à revista Letra Magna. Disponível em [www.letramagna.com/garcezentrevista.htm] Acesso 22/10/2008.

GARCEZ, Pedro M. \& RIBEIRO, Branca Telles. (2002). Sociolinguística Interacional. São Paulo: Loyola.

GIOIA, Diana. Actos linguísticos Descorteses. Mundo Cultural Hispano. <http://www.mundoculturalhispano.com/spip.php?article2298> Acesso em maio/2011. 
GOFFMAN, Erving. (1983). Felicity's condition. In: American Journal of Sociology, 89.1:1-53.

. (1981). Forms of talk . Philadelphia: University of Pennsylvania Press.

. (1975). A representação do eu na vida cotidiana. Petrópolis:Vozes.

. (1974). Frame analysis: an essay on the organization of experience. New York: Harper and Row.

. (1970). Ritual de la interacción. Buenos Aires: Tiempo Contemporáneo.

. (1967). Interaction Ritual: essays on face-to-face behavior. Nova York: Garden

City.

GRICE, H. P. (1980/82). Lógica e conversação. In: DASCAL, M. (org.). Fundamentos Metodológicos da Linguística: Pragmática. São Paulo: Editora do autor.

GUMPERZ, J. (1982a). Discourse strategies. Cambridge: Cambridge University Press.

. (1982b). Language and social identity. Cambridge: Cambridge University Press.

HALLIDAY, M. A. K. (1985). An introduction to functional grammar. New York: Edward Arnold.

. (1976). Estrutura e função da linguagem. In: LYONS, John (org.). Novos horizontes em linguística. São Paulo: Cultrix / EDUSP.

HILGERT, José Gaston.(2000). A construção do texto 'falado' por escrito: a conversação na Internet. In: PRETI, Dino (org.). Fala e escrita em questão. São Paulo:Humanitas.

(1989). A paráfrase - um procedimento de constituição do diálogo. USP, tese de doutorado.

ILARI, R. et ali.(1992). Semântica. S. Paulo: Ática.

JONSSON, E. (1997). Electronic discourse: on speech and writing on the Internet. Disponível em: [http://www.ludd.luth.se/users/jonsson/Dessay/ ElectronicDiscourse.html]. Acesso em: 10/10/2005.

JUBRAN, C. C. A. S. (2006). A perspectiva textual-interativa. In:JUBRAN, C. C. A. S.; KOCH, I. G. V. (orgs.). Gramática do Português Culto Falado no Brasil - Vol. 1. Campinas: Ed. Unicamp. pp. 27-38. 
JUBRAN, C. C. S.; H. URBANO; L. L. FÁVERO; I. G. V. KOCH; M. S. RISSO et ali. (1992). Organização tópica da conversação. In: R. ILARI (org.) Gramática do Português Falado, 2: Níveis de Análise Lingüística. Campinas: Edunicamp/Fapesp. pp.357-479.

KERBRAT-ORECCHIONI, Catherine (2006). Análise da conversação. Princípios e Métodos. São Paulo:Parábola Editorial.

. (2005). Le discours en interaction. Paris: Armand Colin.

(1998). Les interactions verbales Paris: Armand Colin.

$\mathrm{KOCH}$, Ingedore G. V. (2002). A repetição na língua falada como estratégia de formulação textual. In. KOCH, Ingedore V. (Org.) Gramática do Português Falado. Desenvolvimentos. Vol. VI. 2a ed. São Paulo: UNICAMP.

. (1998). Aspectos linguísticos, sociais e cognitivos na produção de sentido. Texto apresentado por ocasião do GELNE, 2-4 de setembro (mimeo).

$\mathrm{KOCH}$, Ingedore Grunfeld Villaça et ali. (1990). Aspectos do processamento do fluxo na informação no discurso oral dialogado. In: CASTILHO, A. T. de. (Orgs.) Gramática do português falado, v. 1. Campinas, SP: Editora UNICAMP; São Paulo: FAPESP. pp. 143-184.

LAKOFF, Robin (1973). The logic of politeness: or minding your p's ans $q$ 's. Papers from the Nineth Regional Meeting of Chicago Linguistic Society, pp.292 - 305.

LÉVY, Pierre. (2007) Cibercultura. São Paulo: 34.

LEVINSON, S. (2007). Pragmática. São Paulo: Martins Fontes.

. (1983). Pragmatics. Cambridge: Cambridge University Press.

MACHADO, Irene (2002). "Semiótica como teoria da comunicação". Tensões e objetos da pesquisa em comunicação. Porto Alegre: Sulina.

- (2000). Gêneros Digitais e suas fronteiras na Cultura Tecnológica. In: Revista Educação \& Tecnologia Rio de Janeiro: CEFET.

MARCUSCHI, Luiz Antonio (2008). Da fala para a escrita: atividades de retextualização. 9a ed. São Paulo: Cortez.

. (2006). Fenômenos intrínsecos da oralidade - Hesitação. In: JUBRAN, C. C. A. S.;

KOCH, I. G. V. Gramática do Português Culto Falado no Brasil. Vol. 1. Campinas: Ed. Unicamp.

. (2005). Análise da Conversação. 5a ed. São Paulo: Ática. 
. (2004). Gêneros textuais emergentes no contexto da tecnologia digital. In: MARCUSCHI, Luiz Antônio; XAVIER, Antônio Carlos (orgs.). Hipertexto e gêneros digitais: novas formas de construção de sentido. Rio de Janeiro: Lucerna.

. (2002). Gêneros textuais emergentes no contexto da tecnologia digital. Texto da Conferência pronunciada na 50a Reunião do GEL - Grupo de Estudos Linguísticos do Estado de São Paulo, USP, São Paulo, 23-25 de maio.

. (2001). Da fala para a escrita: atividades de retextualização. São Paulo: Cortez.

- (1998a). Referência e Cognição. O caso da Anáfora sem Antecedente. Apresentado no Encontro de Linguística em dezembro de 1998, UFJF, Juiz de Fora.

- (1998b). Aspectos da progressão referencial na fala e na escrita no português brasileiro. In: Fala e Escrita: Características e usos. Projeto Integrado, proc. 523612/96-6, financiado pelo CNPq. mimeo.

. (1996). A repetição na língua falada como estratégia de formulação textual. In: $\mathrm{KOCH}$, Ingedore G. V. (Org.). Gramática do português falado 6: desenvolvimentos. Campinas: Editora da Unicamp/ FAPESP. pp. 95-129.

. (1989). Marcadores conversacionais do português brasileiro: formas, posições e funções. In: CASTILHO, Ataliba Teixeira de (org.). Português culto falado no Brasil. Campinas: UNICAMP, pp. 281-321.

(1987). Marcadores conversacionais no português brasileiro: formas, posições e funções. (cópia xerografada).

MARTINS, Carla. (2002). Meaning Indeterminacy in Socio-Pragmatic Studies: Theoretical and Methodological Divergence. DELTA. São Paulo, v. 18, n. 1. Disponível em: [http://www.scielo.br/]. Acesso em: 24/09/2006

MEIER, A.J. (1995). Passages of Politeness. In: Journal of Pragmatics, vol.24, n.04, Oct.

MCCLEARY, Leland Emerson. (1996). Aspectos de uma modalidade de discurso mediado por computador. São Paulo. Tese de doutoramento. São Paulo: USP.

MODESTO, Artarxerxes T. T. (2006). Formas de tratamento no Português Brasileiro: a alternância tu/você na cidade de Santos/SP. Dissertação de Mestrado. São Paulo:USP.

MORENO FERNÁNDEZ, F. Principios de solingüística y sociología del lenguaje. Barcelona: Ariel, 1998. 
NADER, Valéria Holzmann. (2001) A interação virtual em diálogos na internet: novas possibilidades para a análise do discurso. São Paulo. Dissertação de Mestrado. São Paulo:USP.

RODRIGUES, A. C. S. (1993). Língua falada e língua escrita. In: D. PRETI (ed.) Análise de textos orais. São Paulo: FFLCH/USP.

RODRÍGUEZ, Catalina Fuentes \& LARA, Esperanza R. Alcaide.(2008). (Des)cortesía, agresividad y violencia verbal en la sociedad actual. Sevilla: Universidad Internacional de Andalucía.

(2006). Manifestaciones textuales de La Descortesia y Agressividad verbal em diversos Ámbitos Comunicativos. Sevilla: Universidad de Sevilla.

ROSA, Margaret. (1992). Marcadores de atenuação. São Paulo: Contexto.

RISSO, Mercedes S. (1996). O articulador discursivo "então". In: CASTILHO, A.T. \& BASÍLIO, Margarida. (org.) Gramática do Português Falado. Campinas: UniCamp, pp. $423-451$.

RISSO, Mercedes S. et al. (2006). Traços definidores dos marcadores discursivos. In: JUBRAN,C.C.A \& KOCH, I.G.V. (org.). Gramática do Português Culto Falado no Brasil. Campinas: Ed. da UNICAMP, pp.403-427.

- (1996). Marcadores discursivos: traços definidores. In: KOCH, Ingedore G V. (org.). Gramática do português falado: desenvolvimentos. Vol. 6. Campinas:UNICAMP/FAPESP, pp. 21-94.

SACKS, H., SCHEGLOFF, E.E. e JEFFERSON. (1974). G. A simplest systematic for the organization of turn-taking for conversation. Language. 50, 696-735.

SEARLE, J. (1969). Speech Acts. Cambridge: Cambridge University Press.

SILVA, Luiz Antonio da. (org.) (2008). A língua que falamos. Português: História, Variação e Discurso. São Paulo: Editora Globo.

.(2005). Formas de tratamento e papéis familiares. In: IV Congresso Internacional da ABRALIN, Brasília. Livro de Resumos. Brasília : ABRALIN/UNB.

. (1999). Polidez na interação professor/aluno. In: PRETI, Dino (org.). Estudos de língua falada: variações e confrontos. São Paulo: Humanitas. pp.109-130

STUBBS, Michael.(1980).Language and literacy: The sociolinguistics of reading and writing. London: Routledge and Kegan Paul. 
URBANO, Hudinilson.(1993). Marcadores conversacionais. In: PRETI, Dino (org.). Análise de textos orais. São Paulo: FFLCH/USP. pp.81- 101

VILLAÇA, Ingedore; BENTES, Ana. (2008). Aspectos da cortesia na interação face a face. In: PRETI, Dino. Cortesia Verbal. SãoPaulo:Humanitas. pp.19-48

XAVIER, Antonio Carlos e SANTOS, Carmi Ferraz.(2005) E-forum na Internet: Um gênero Digital. In: ARAÚJO, Júlio César e BIASI-RODRIGUES, Bernadete. (Org.) Interação na Internet. Novas formas de usar a linguagem. Rio de Janeiro: Lucerna. pp.30-38 
ANEXOS 


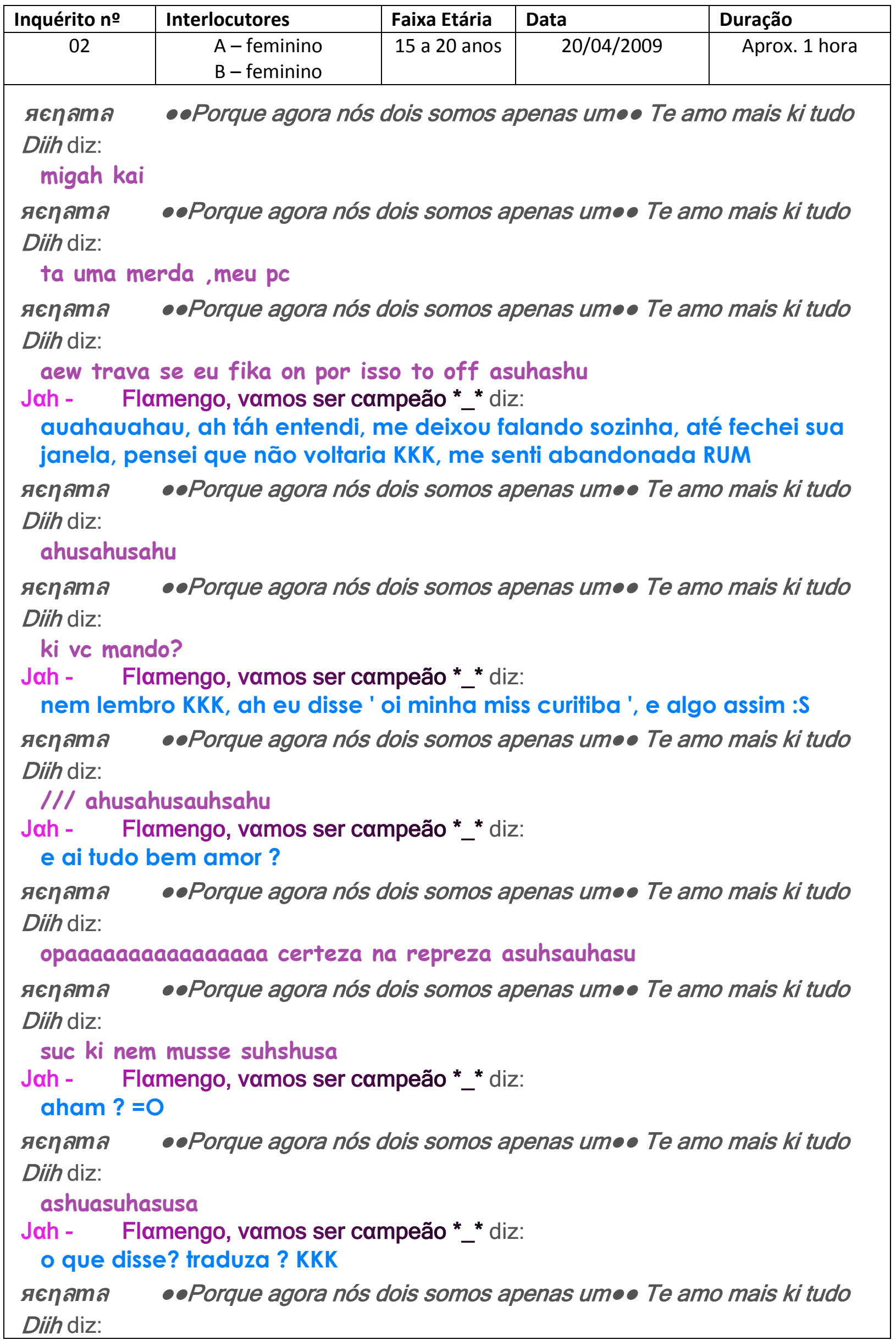




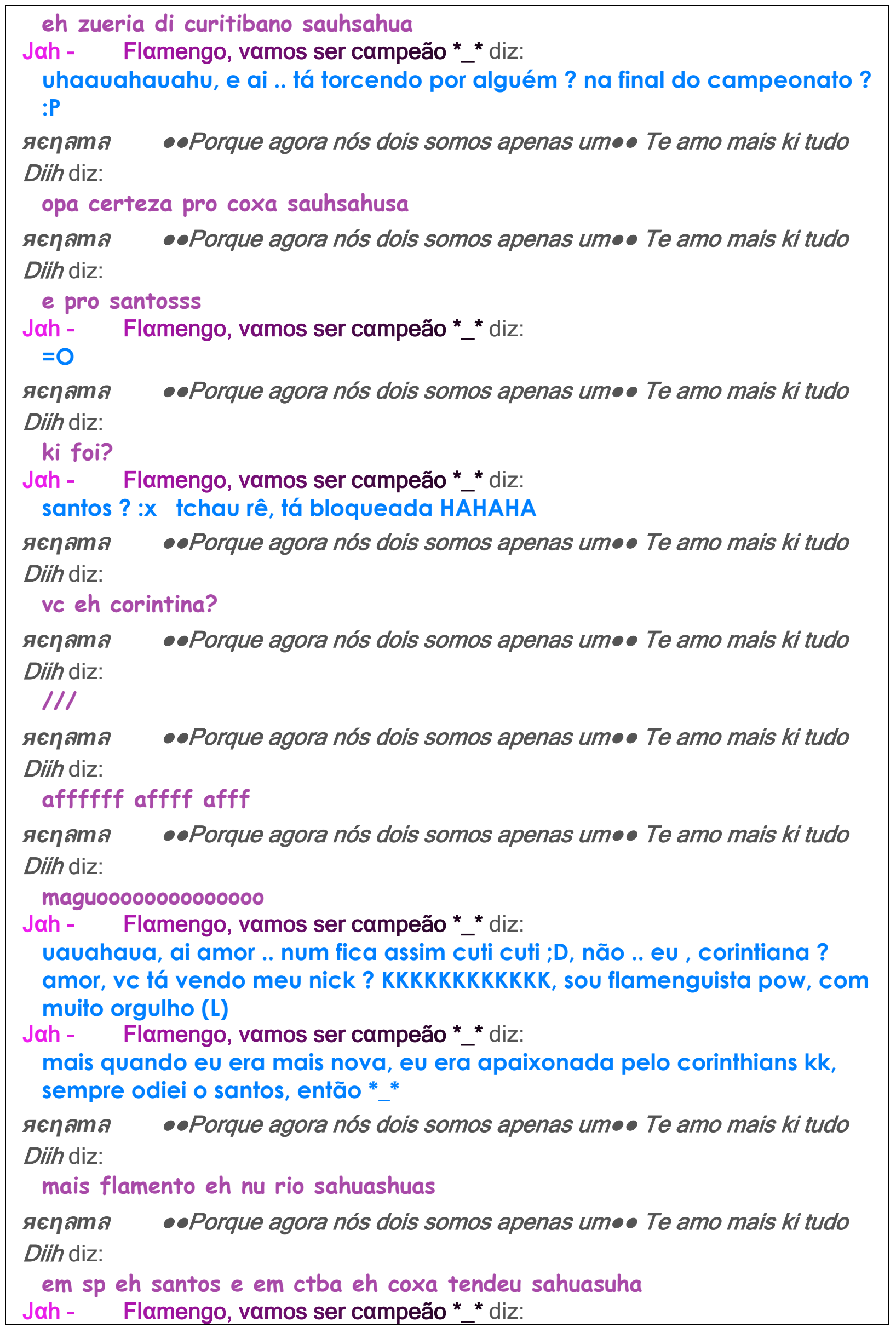


auahauahu, é no rio, mais é o melhor time, fazer o que ? =0 kk.

Jah - Flamengo, vamos ser campeão * * diz:

e domingo, a taça será nossa RUM, o bołafogo que venha com graça pra ver KKK

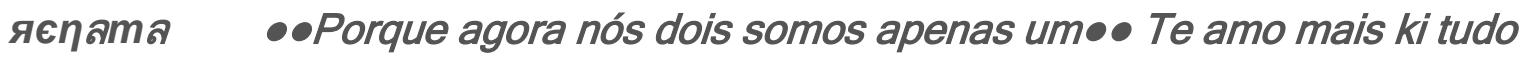

Diih diz:

asuhsahusahuashuashusahuas

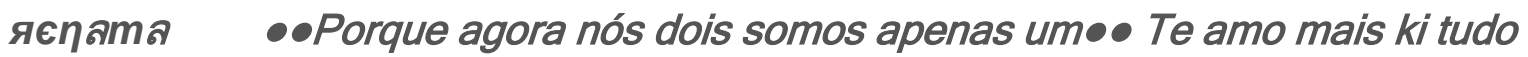

Diih diz:

aiin Jay ne eu me racho com vc ahuasuhashuas

Jah - Flamengo, vamos ser campeão * * diz:

uaahauhaauhaui, eu sou palhaça é ? :S

Jah - Flamengo, vamos ser campeão * * diz:

auaha, sou realista isso sim KKK

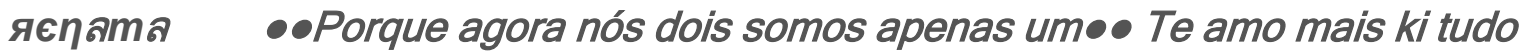

Diih diz:

sauhsauhsahu e nada sauhsahu

Jah - $\quad$ Flamengo, vamos ser campeão * * diz:

.. aham, eu lembrei de vc hoje sabiia ? KKK

Jah - Flamengo, vamos ser campeão * * diz:

quer dizer, eu sempre lembro FIU auahaua, mais hoje lembrei por algo especial kk.

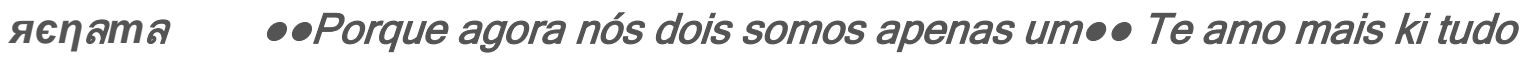
Dith diz:

u 9

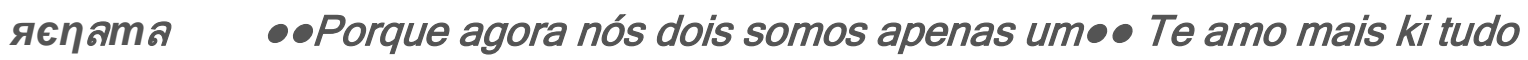

Diih diz:

?

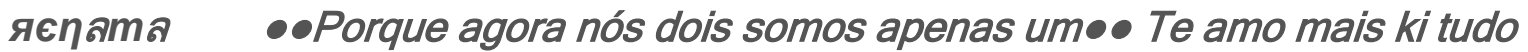

Dith diz:

huashusa

Jah - $\quad$ Flamengo, vamos ser campeão * * diz:

minha amiga disse, que gostava de sei lá o nome é João Bala, algo assim, aquele q vc gosta KKK

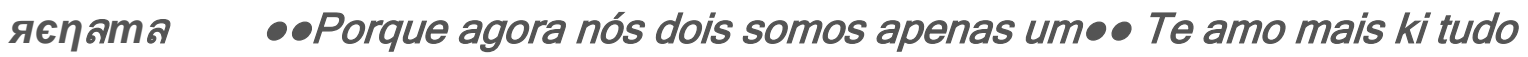

Dith diz:

ham

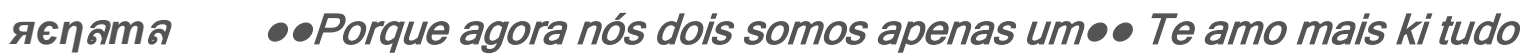

Dith diz:

??????/

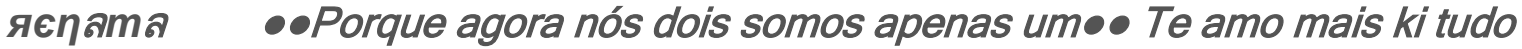

Diih diz:

kem eh esse? 
Jah - Flamengo, vamos ser campeão * * ${ }^{*}$ diz:
aquele q vc me mandou uma musica uma vez, eu esquecil o nome dele
KKK

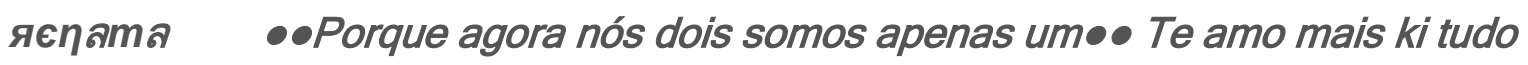
Diih diz: joão bala?

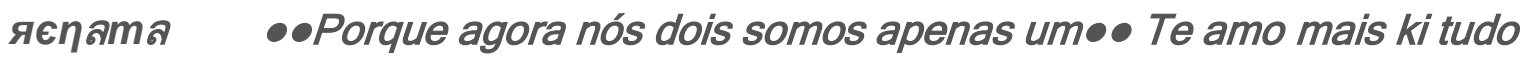
Dith diz:

num eh isso nom

Jah - Flamengo, vamos ser campeão *_* diz:

é algo com João KKK

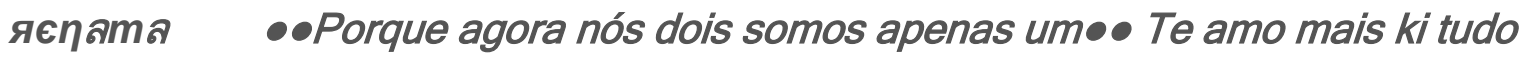

Dith diz:

joao bosco e vinicios?

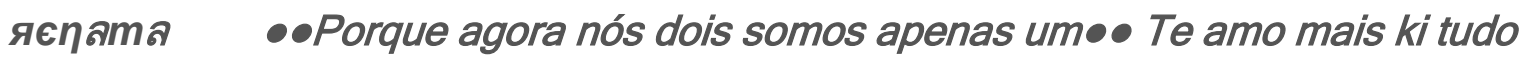
Dith diz:

???

Jah - Flamengo, vamos ser campeão * * diz:

não .. esse eu conheço KKK, que canta aquela musica ' quem mandou largar de mim, se está sofrendo assim, bem feito pra você ' auahaau.

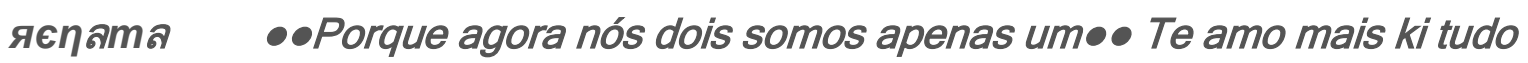
Diih diz:

ihh eu num sei gm eh nom

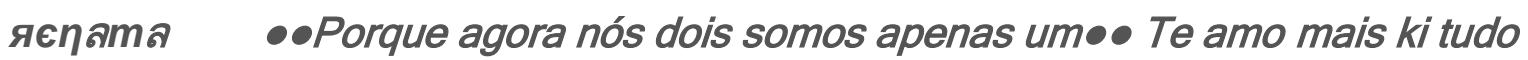

Diih diz:

sahuasuhas

Jah - Flamengo, vamos ser campeão * _ diz:

auahauahau, tá tudo bem KKK

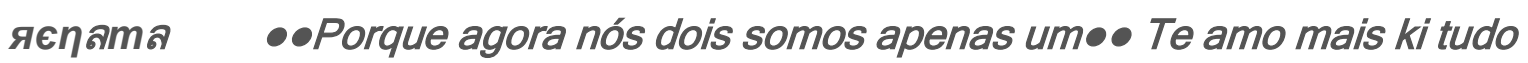

Diihh diz:

se ta confundindo

Jah - Flamengo, vamos ser campeão * * diz:

é .. eu ach que sim HAHAHA

Jah - Flamengo, vamos ser campeão * * diz:

* acho

Jah - Flamengo, vamos ser campeão * * diz:

gostei do seu nick ;D

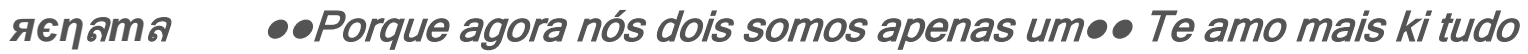

Diih diz:

u q/

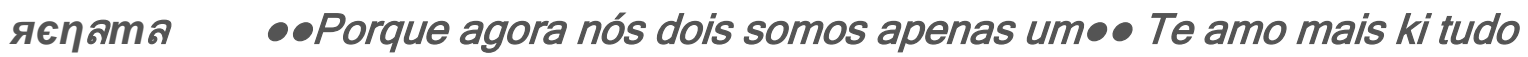

Diih diz:

meu nick ve diz u poeminhal 


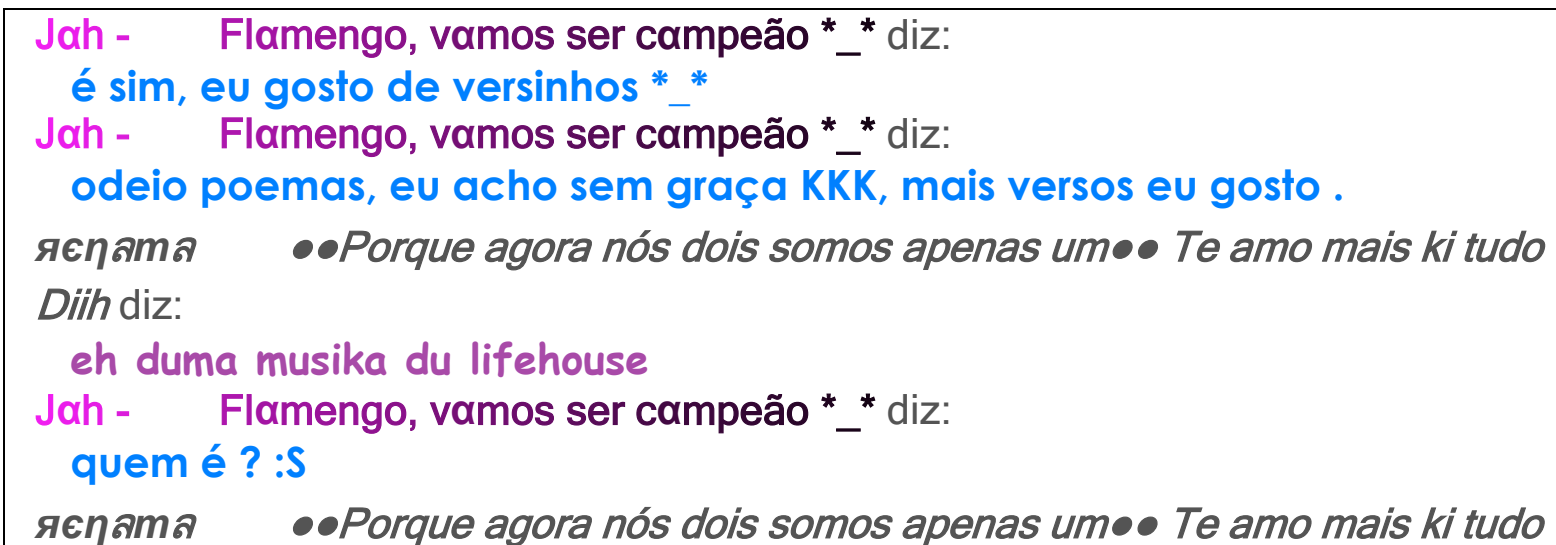
Diih diz:

e uma banda emo asuhashua eh ingles tah sauhsahu

Jah - $\quad$ Flamengo, vamos ser campeão *_ ${ }^{*}$ diz:

kkkkkkkkkk .

Jah - $\quad$ Flamengo, vamos ser campeão * ${ }^{*}$ diz:

emo ? =0

Jah - $\quad$ Flamengo, vamos ser campeão * * diz:

curte bandas emos? ;D

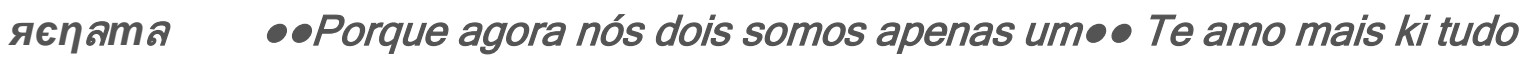
Diih diz:

uhum curtoo sim ummonti sauhsahu

Jah - $\quad$ Flamengo, vamos ser campeão *_ ${ }^{*}$ diz:

uahaquahu, ah eu não curto tanto assim KKK, mais depende, eu sou mto neutra, digamos kk, curto de fudo um pouco * _

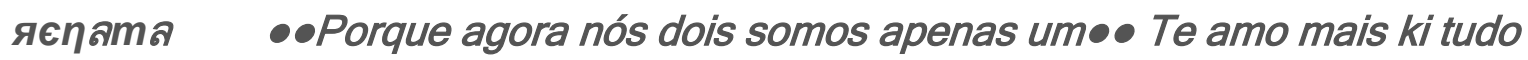
Diih diz:

igual eu sauhsauh

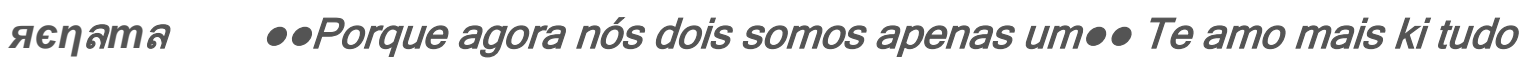
Diih diz:

mais eu gosto de escuta musika assim qdu to depre sahuasuhasuhsahusa Jah - $\quad$ Flamengo, vamos ser campeão * _ ${ }^{*}$ diz:

HAHAHA

Jah - $\quad$ Flamengo, vamos ser campeão * * diz:

eu também, no meu cel , as musicas estão dividas tipow ' tristes, alegres, romanticas ', ai depende do meu humor, eu escuto KKK

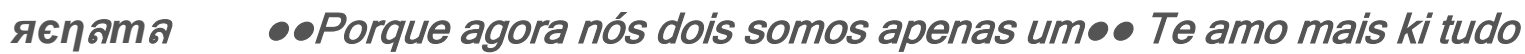

Diih diz:

ashusahuashuashusauh

яєпลmล $\quad \bullet P$ Porque agora nós dois somos apenas um•• Te amo mais ki tudo

Diih diz:

qdu vc ta brava vc escuta u q/

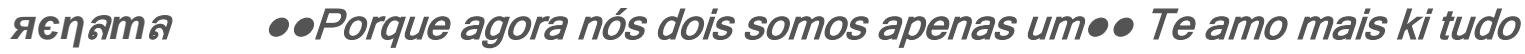

Diih diz:

huauhaus 


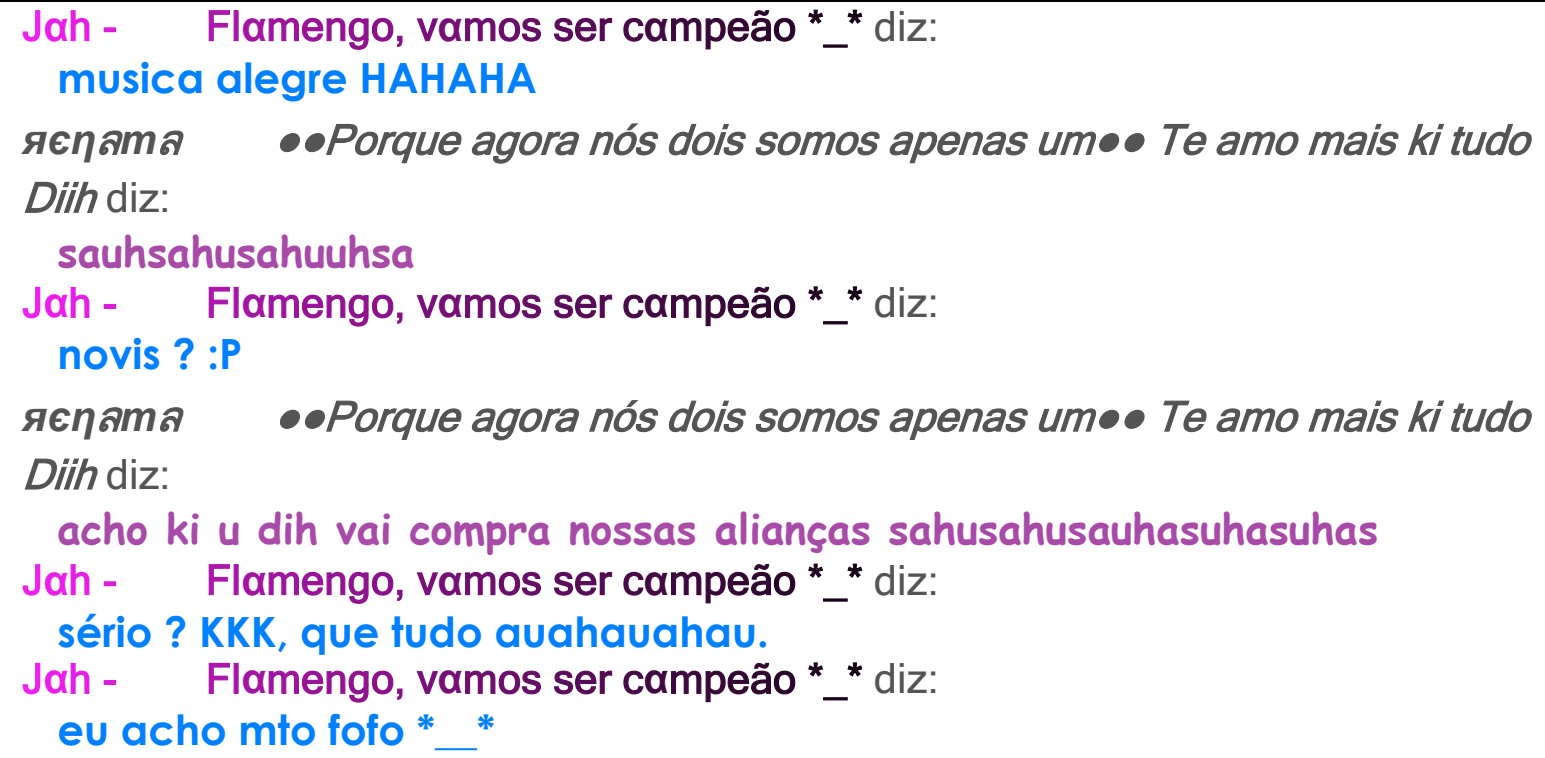

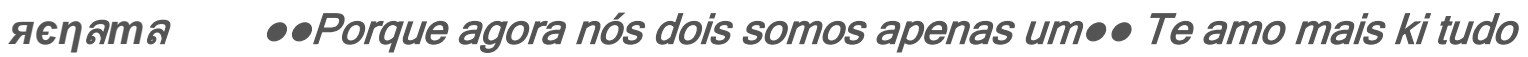
Diih diz:

a genti vai nu jardim botanico e vamu nu shopiss

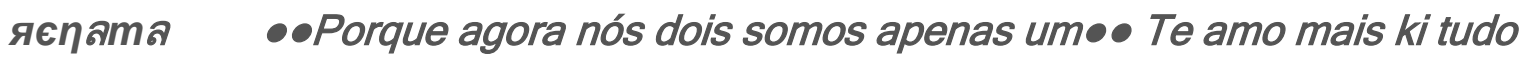
Dith diz:

affff to morrendo de xudadi deleee

Jah - Flamengo, vamos ser campeão *_* diz:

auahauahau, ai que lindo ** mais é sério, juizo mesmo RUM, eu confio em vc, nele não kk.

Jah - Flamengo, vamos ser campeão * * diz:

mais abafa auahau.

яєпลmล $\quad \circ$ Porque agora nós dois somos apenas um॰० Te amo mais ki tudo Diih diz:

\section{affffffffffffffffffffffff}

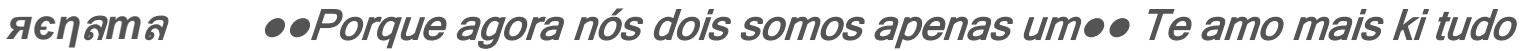
Diih diz: 


\section{comoo assimmm}

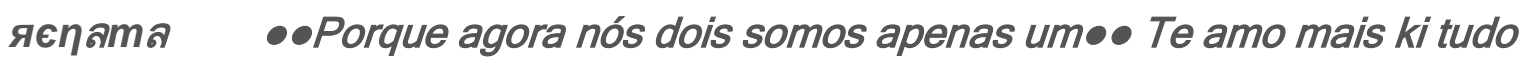

Diihh diz:

sauhasuhusa

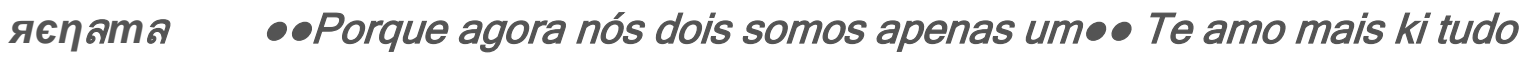

Diih diz:

ki vc sabe ki eu num sei sauhasuhasuhas

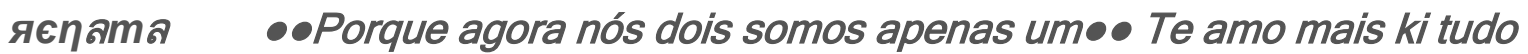

Diih diz:

pohhhhhh me contaaaaaaaaa

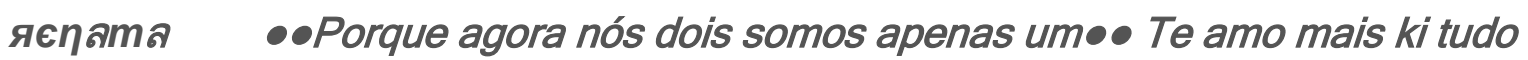

Diih diz:

ashuauhas

Jah - Flamengo, vamos ser campeão * * diz:

aham ? =0

Jah - Flamengo, vamos ser campeão * * diz:

contar o que ? HAHAHA

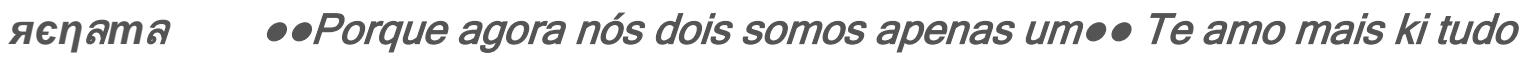

Diih diz:

pq ve num confia nele?

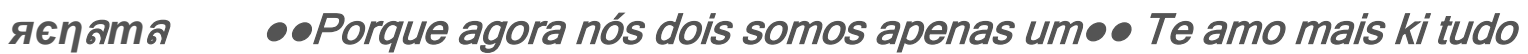

Diih diz:

???????????????

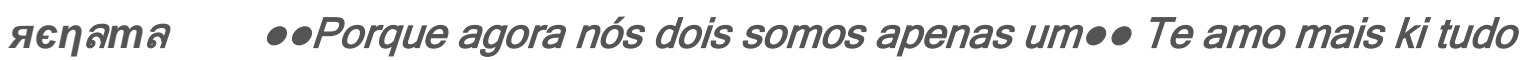

Diih diz:

hein hein hein?

Jah - Flamengo, vamos ser campeão * * diz:

auahauahaua, ah nada .. KKK, além do mais tipo, você é batizada,

organista, ele não, ele é musico só, nem é batizado, e só cgg no culto de jovens kk, é o que eu vejo :S

Jah - Flamengo, vamos ser campeão * * diz:

fico preocupada, de vc fazer uma besteira, tentação sabe ? me preocupo pq é minha gatinha linda ; $D$, mais por isso eu digo JUIZO :X

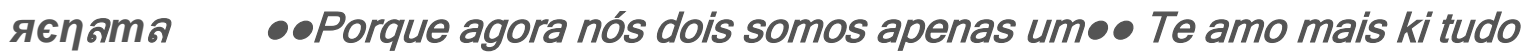

Diih diz:

ahhh pq ve num conhece us cara akew ki eh batizado

Jah - Flamengo, vamos ser campeão * * diz:

ele vai dormir ai na sua casa e tals kk, ai né :S,

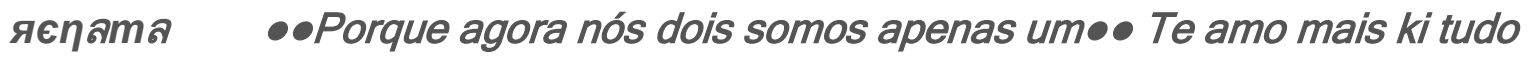

Diih diz:

nom nom migah aff $u$ Dih moh séério

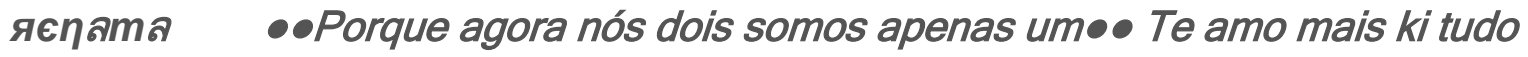

Diih diz: 


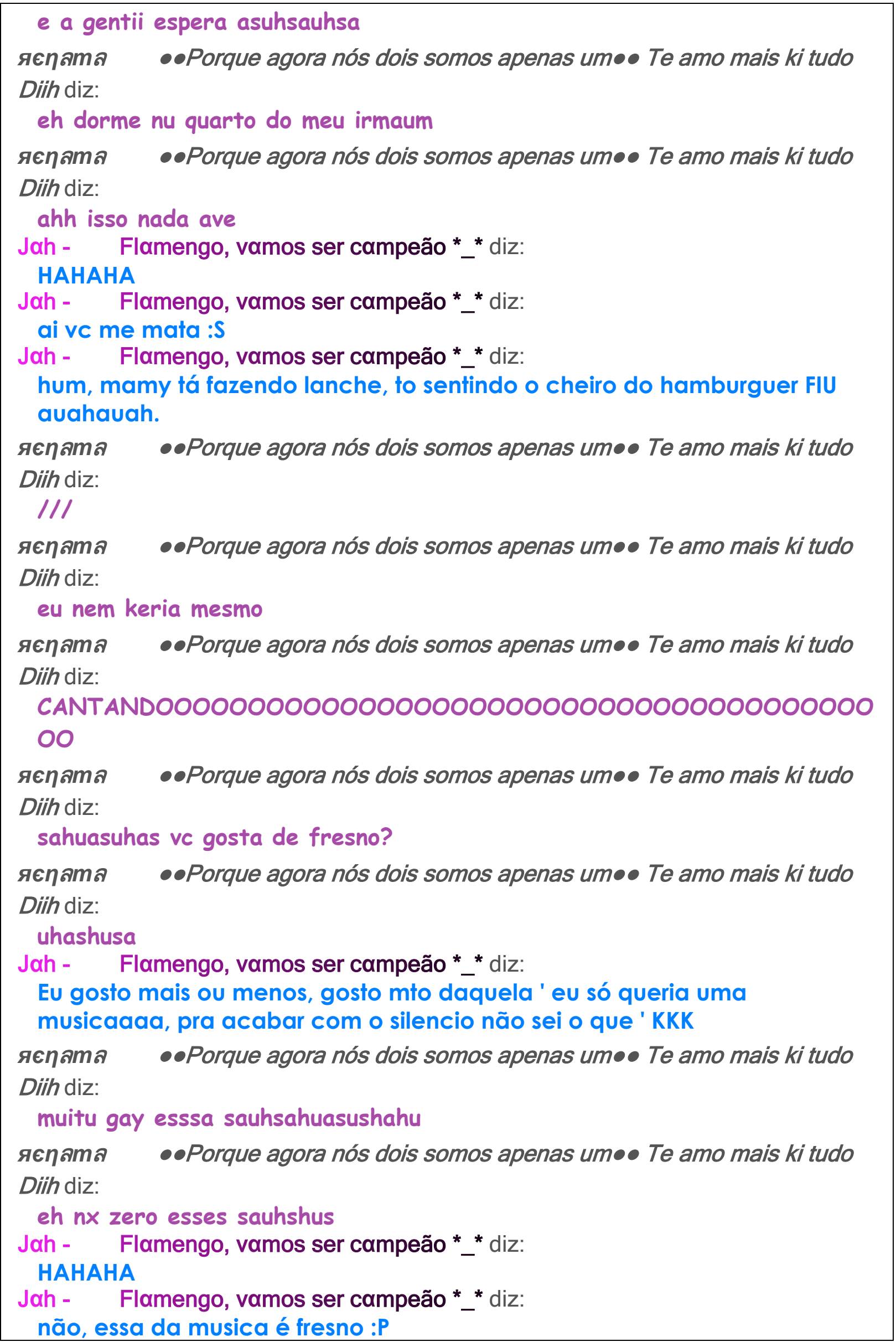




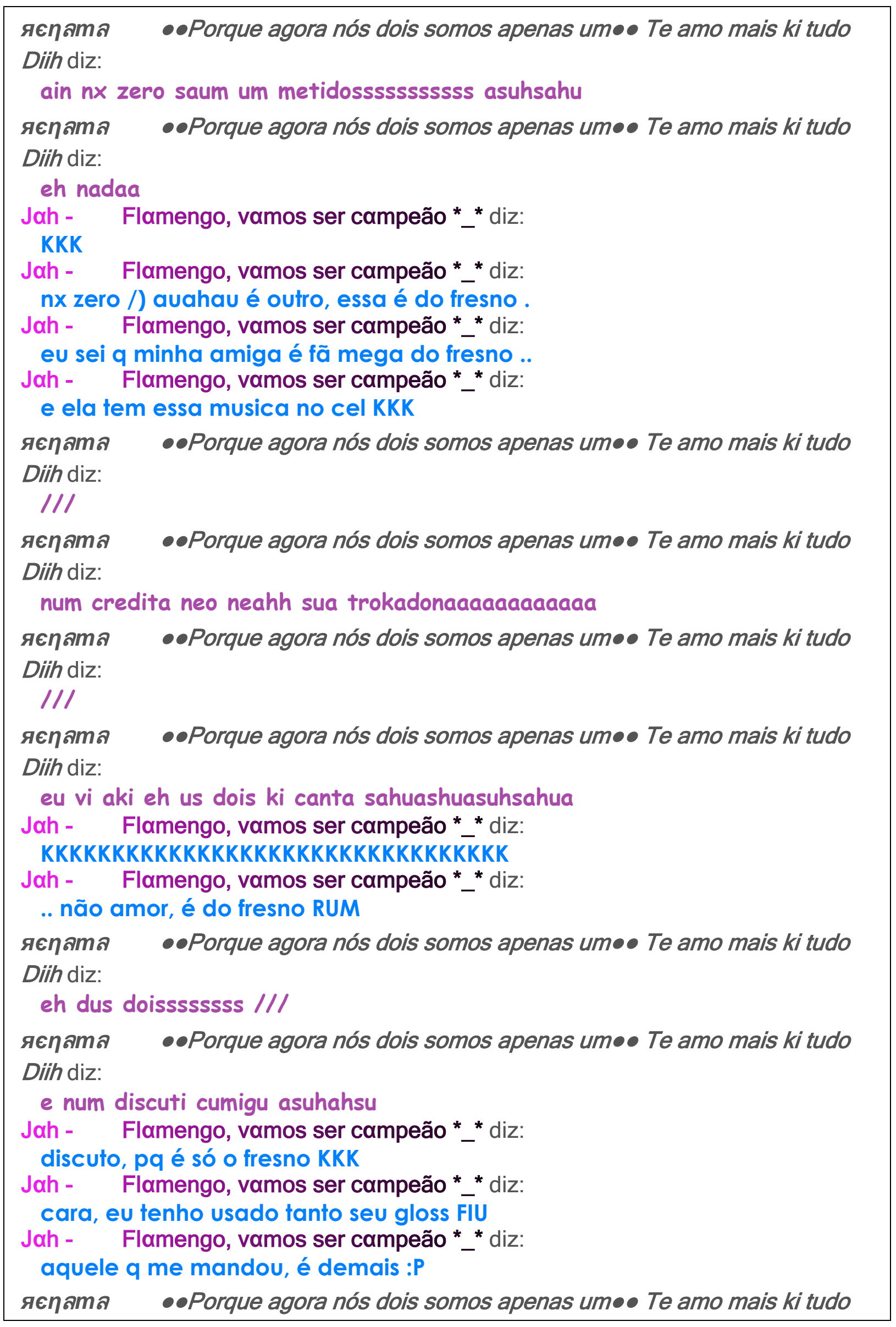




\section{Diih diz:}

sauasuhasuhas u meu ta acabando asuhashu

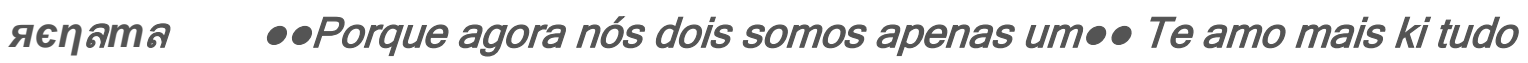

Diih diz:

tenhu ki compra outro

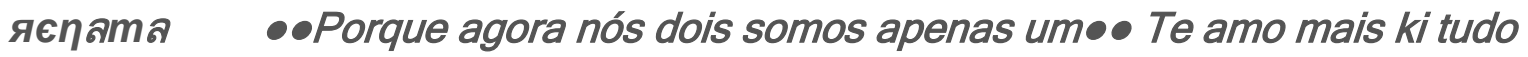

Diih diz:

minhas makiagens ta tudu acabando sauhshusa

Jah - Flamengo, vamos ser campeão * * diz:

eu também tenho q comprar auahauahu.

Jah - $\quad$ Flamengo, vamos ser campeão * ${ }^{*}$ diz:

eu encomendo da minha tia KKK

Jah - Flamengo, vamos ser campeão *_ * diz:

mais faz tempo q não vejo catalogo :S

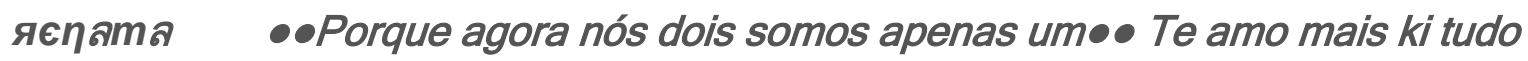

Diih diz:

sauhsahusau eu tb

Jah - $\quad$ Flamengo, vamos ser campeão * * diz:

auahauahauahaau.

Jah - Flamengo, vamos ser campeão * * diz:

imitona RUM

Jah - Flamengo, vamos ser campeão * * diz:

amor, eu vou indo, vou ver um video aqui, com meus irmãos KKK, e comer lanche, e sair, pq mamys vai entrar tá ?

Jah - Flamengo, vamos ser campeão * * diz:

amanhã se falamos mais :P

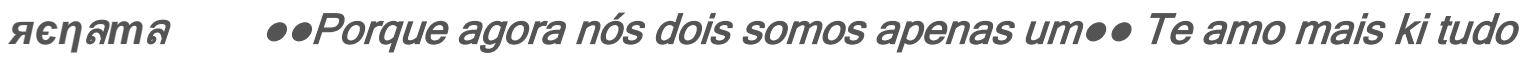

Diih diz:

huashusa

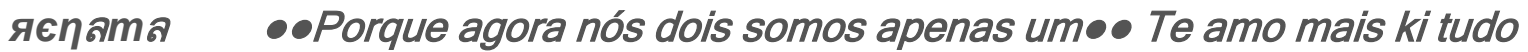

Diih diz:

$$
\text { //I }
$$

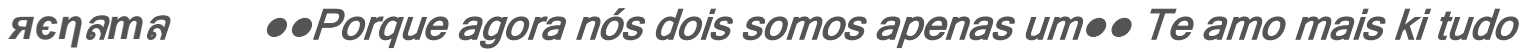

Diih diz:

ta ta saudaa eles aew mandaa beju

Jah - Flamengo, vamos ser campeão * * diz:

auahauahau, tá bom meu anjito ;D

Jah - Flamengo, vamos ser campeão * * diz:

te amo minha miss KKK

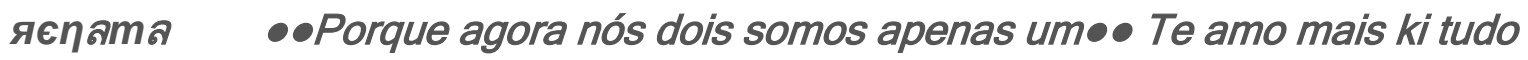

Diih diz:

ti cuidaa

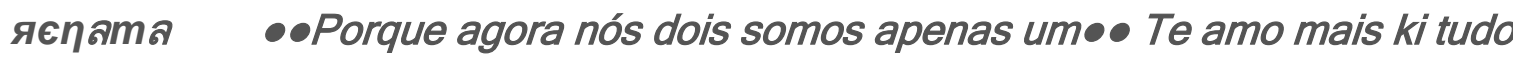

Diih diz: 


\begin{tabular}{|c|c|}
\hline หยทลmล & -๑Porque agora nós dois somos apenas um॰• Te amo mais ki tudo \\
\hline $\begin{array}{l}\text { Diih diz: } \\
\text { bezoO }\end{array}$ & \\
\hline $\begin{array}{l}\text { Jah - } \\
\text { beijão. }\end{array}$ & Flamengo, vamos ser campeão *_ * diz: \\
\hline หยทลmล & - Porque agora nós dois somos apenas um॰• Te amo mais ki tudo \\
\hline $\begin{array}{l}\text { Diih diz: } \\
\text { BezoO }\end{array}$ & \\
\hline
\end{tabular}




\begin{tabular}{|c|c|c|c|c|}
\hline Inquérito no & Interlocutores & Faixa Etária & Data & Duração \\
\hline 26 & $\begin{array}{l}\text { A - masculino } \\
\text { B - feminino }\end{array}$ & 21 a 30 anos & $04 / 07 / 2007$ & 30 minutos \\
\hline \multicolumn{5}{|c|}{$\begin{array}{l}\text { Marco Antonio diz: } \\
\text { oi } \\
\text { Jen Jen diz: oi }\end{array}$} \\
\hline \multicolumn{5}{|c|}{$\begin{array}{l}\text { Marco Antonio diz: } \\
\text { fazendo oq nas ferias }\end{array}$} \\
\hline \multicolumn{5}{|c|}{ ? } \\
\hline \multicolumn{5}{|c|}{ Jen Jen diz: } \\
\hline \multicolumn{5}{|c|}{$\begin{array}{l}\text { Marco Antonio diz: } \\
\text { descançando e fazendo meu trabalho de iniciação }\end{array}$} \\
\hline \multicolumn{5}{|c|}{$\begin{array}{l}\text { Marco Antonio diz: } \\
\text { lendo um pouco sobre direito tbm }\end{array}$} \\
\hline \multicolumn{5}{|c|}{ Jen Jen diz: } \\
\hline \multicolumn{5}{|c|}{$\begin{array}{l}\text { Marco Antonio diz: } \\
\text { vc faz parte do }\end{array}$} \\
\hline \multicolumn{5}{|c|}{ Marco Antonio diz: } \\
\hline \multicolumn{5}{|c|}{ Marco Antonio diz: } \\
\hline \multicolumn{5}{|c|}{$\begin{array}{l}\text { Marco Antonio diz: } \\
\text { neh }\end{array}$} \\
\hline \multicolumn{5}{|c|}{ Jen Jen diz: } \\
\hline \multicolumn{5}{|c|}{ Marco Antonio diz: } \\
\hline \multicolumn{2}{|c|}{ fui....mas não por causa do gedi } & & & \\
\hline \multicolumn{5}{|c|}{ Jen Jen diz: } \\
\hline \multicolumn{5}{|c|}{$\begin{array}{l}\text { Marco Antonio diz: } \\
\text { hum }\end{array}$} \\
\hline \multicolumn{5}{|c|}{$\begin{array}{l}\text { Marco Antonio diz: } \\
\text { mas ele nao funciona nas ferias }\end{array}$} \\
\hline \multicolumn{5}{|c|}{ Marco Antonio diz: } \\
\hline \multicolumn{5}{|c|}{$\begin{array}{l}\text { Marco Antonio diz: } \\
\text { pegar livros ta estudando na }\end{array}$} \\
\hline \multicolumn{2}{|c|}{$\begin{array}{l}? \\
\text { Jen Jen diz: }\end{array}$} & \multicolumn{3}{|c|}{$\begin{array}{l}\text { Marco Antonio diz: } \\
\quad ?\end{array}$} \\
\hline
\end{tabular}




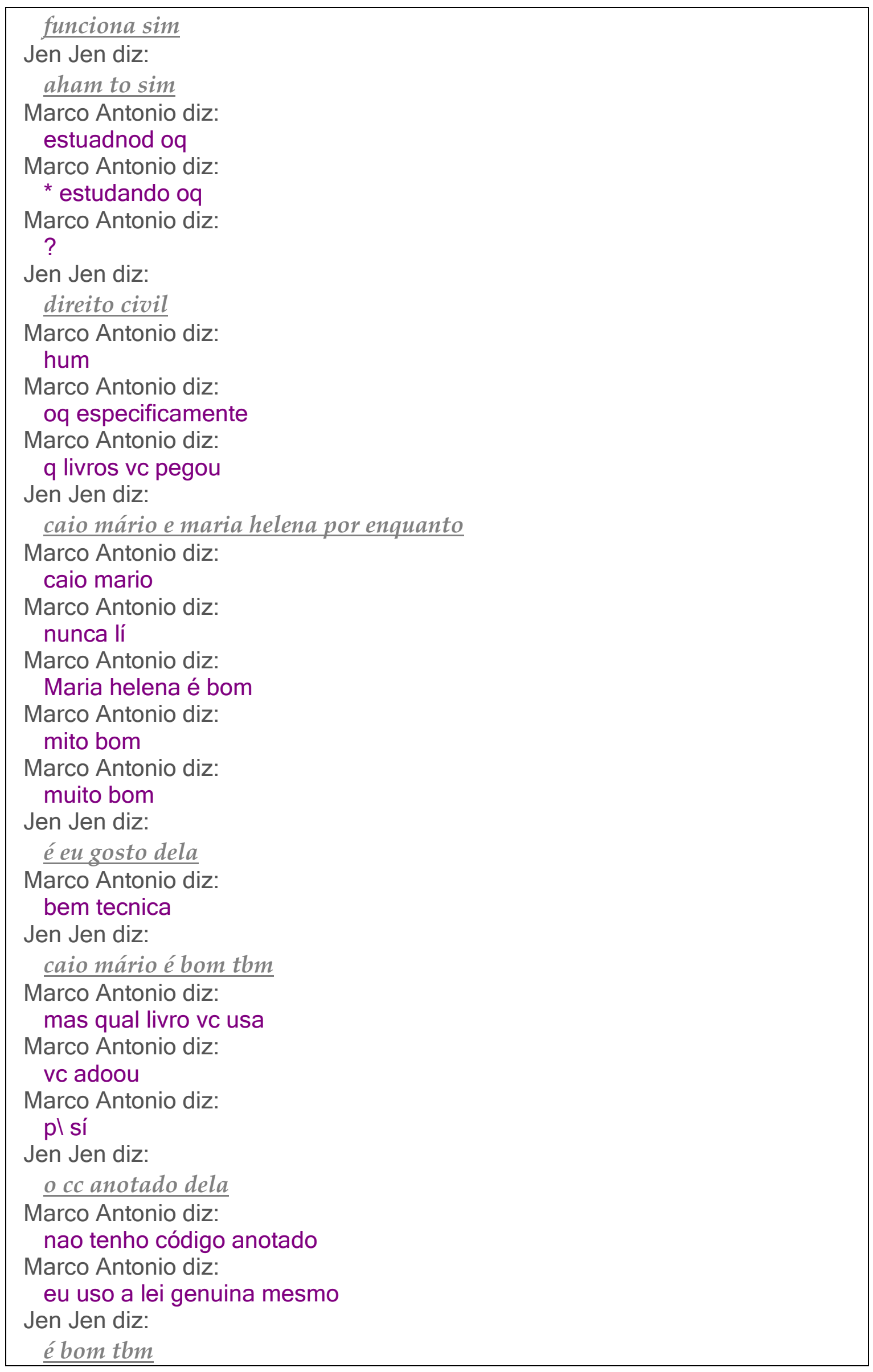




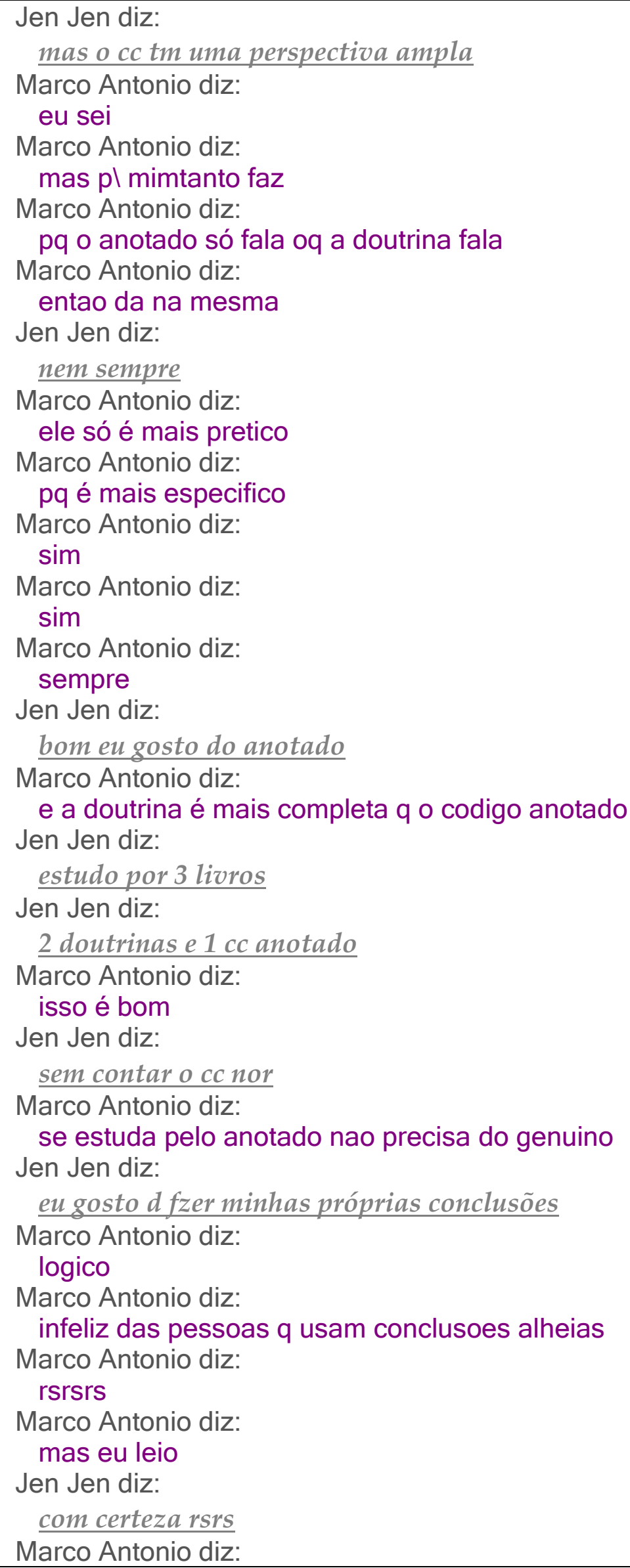




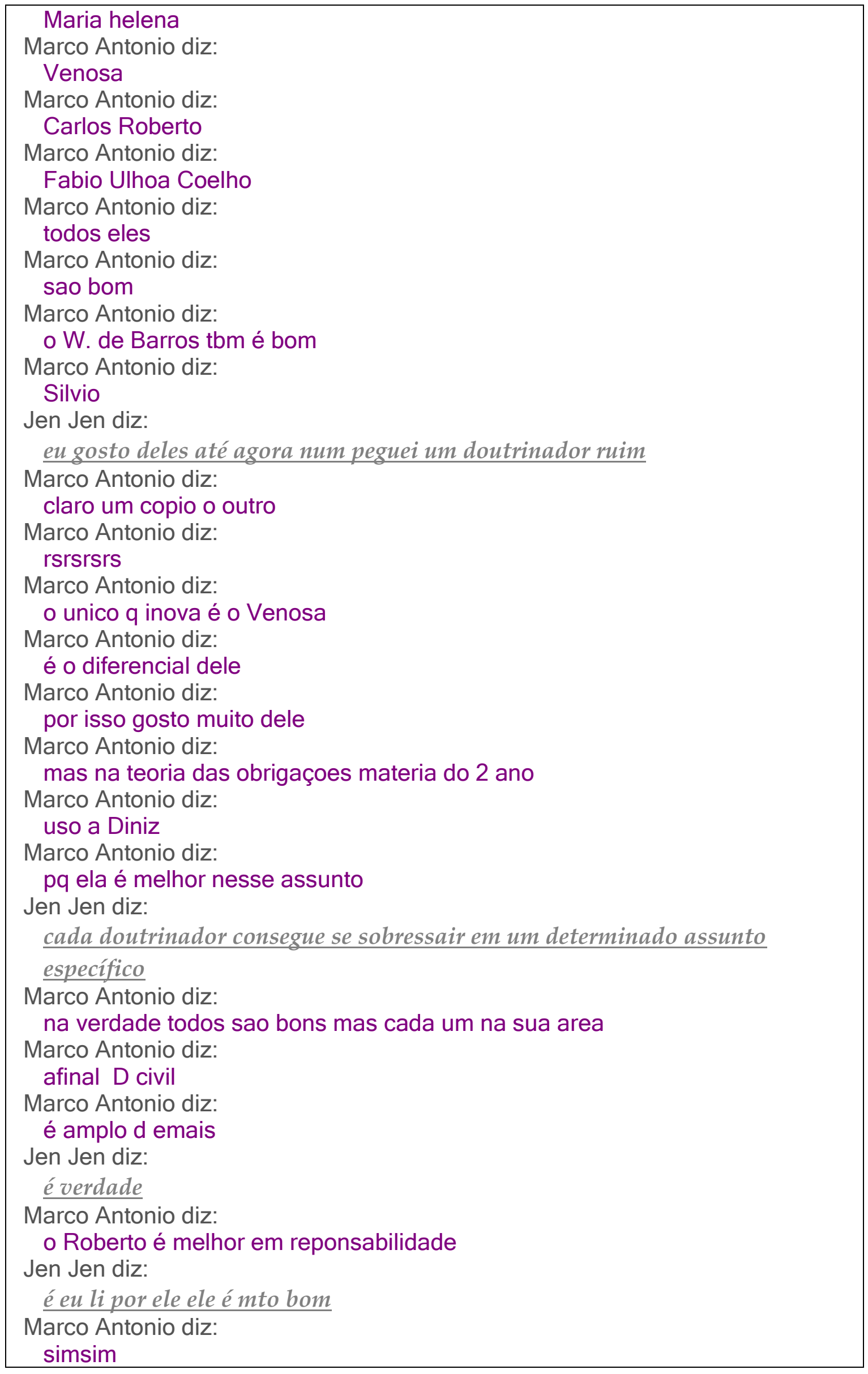




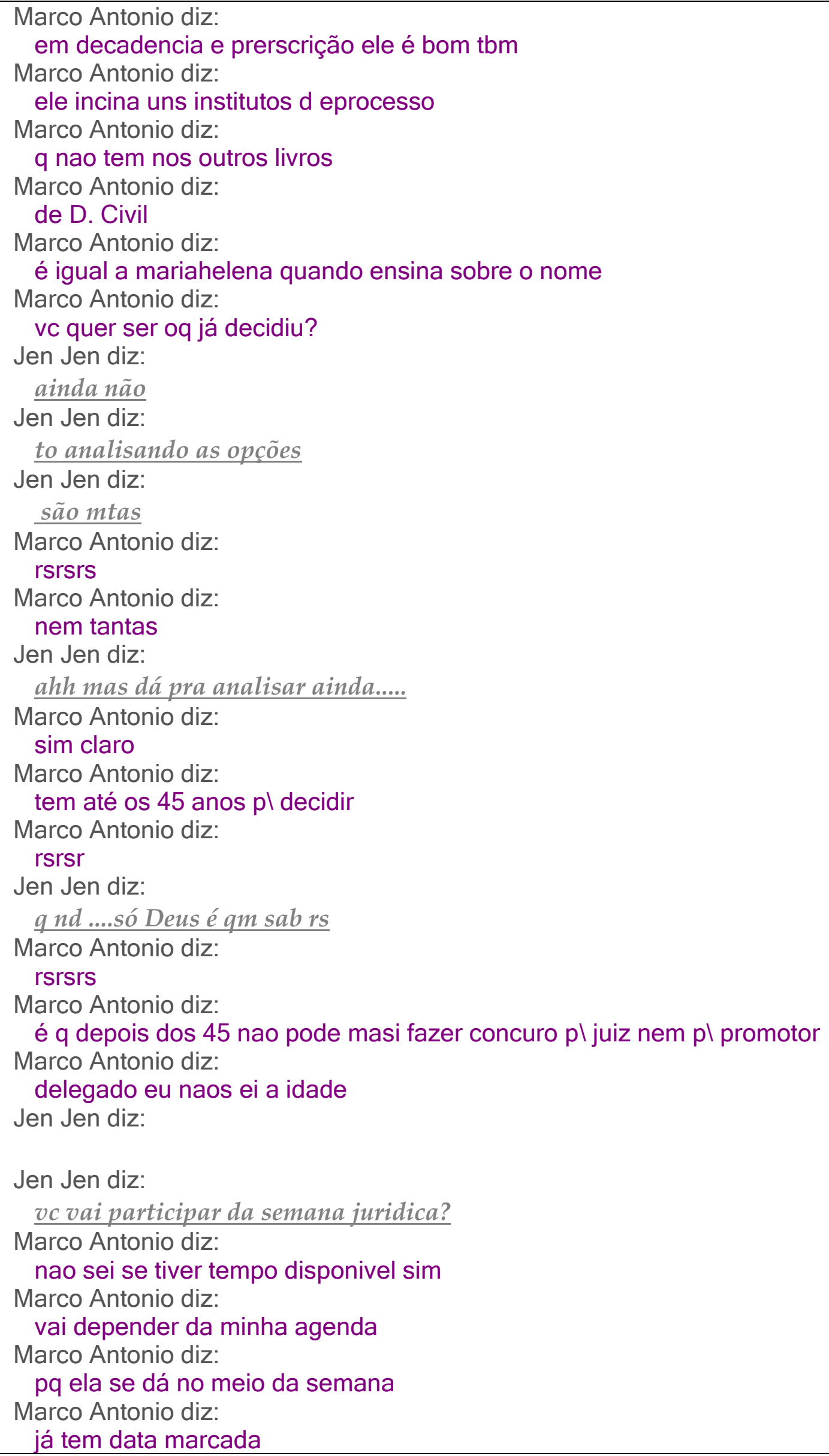




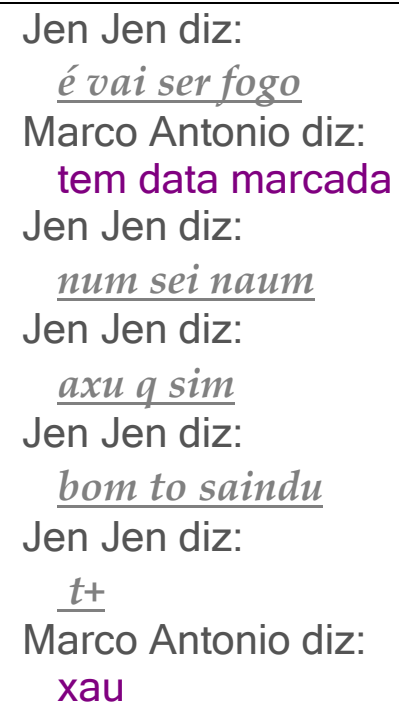




\begin{tabular}{|c|c|c|c|c|}
\hline Inquérito no & Interlocutores & Faixa Etária & Data & Duração \\
\hline 24 & $\begin{array}{c}\text { A - masculino } \\
B-\text { feminino }\end{array}$ & $\begin{array}{c}31 \text { anos em } \\
\text { diante }\end{array}$ & $17 / 04 / 2010$ & 31 minutos \\
\hline (20:56) Marília: & \multicolumn{4}{|l|}{ boinote! } \\
\hline (20:56) Carlos: & \multicolumn{4}{|l|}{ noite! } \\
\hline (20:57) Marília: & \multicolumn{4}{|c|}{ quer dizer... boa nooite.... rs rs $: ;$} \\
\hline (20:58) Carlos: & \multicolumn{4}{|l|}{ rsrsrsrs } \\
\hline (20:59) Marília: & \multicolumn{4}{|c|}{ hoje fiz aquele bolo com a recita que me deu... } \\
\hline (21:01) Marília: & \multicolumn{4}{|l|}{ uma delícia! } \\
\hline (21:01) Carlos: & \multicolumn{4}{|c|}{ ashah realmente o bolo de aipim com quejinho e demais... } \\
\hline (21:03) Marília: & \multicolumn{4}{|c|}{ comi tudo nem deixi pros mininos...rshshrshrhshrs } \\
\hline (21:03) Carlos: & \multicolumn{4}{|c|}{ gulosa! Cadê meu pedacinhooo ??? : : : : : } \\
\hline (21:04) Marília: & \multicolumn{4}{|c|}{ fasso outro depois.... aquele.... ahahahahahajaá ta no papo... } \\
\hline (21:05) Carlos: & \multicolumn{4}{|l|}{ a vitória dá ti? } \\
\hline (21:07) Marília: & \multicolumn{4}{|l|}{ ?????? } \\
\hline (21:08) Carlos: & \multicolumn{4}{|c|}{ a vitória tá ai? Ops! } \\
\hline (21:09) Marília: & \multicolumn{4}{|c|}{ Tá sim..ç quer que eu chame???? } \\
\hline$(21: 10)$ Carlos: & \multicolumn{4}{|c|}{ Dpois, o papo do bolo tá bom.... rs rs } \\
\hline (21:11) Marília: & \multicolumn{4}{|c|}{ tá qeredo comer meu bolo NE safado! $\odot ;$} \\
\hline (21:12) Carlos: & \multicolumn{4}{|c|}{ Epa, sou casado! Rspeito! A lúcia tá aqui do meu lado! } \\
\hline (21:13) Carlos: & \multicolumn{4}{|l|}{ \#mortecerta!\# } \\
\hline (21:15) Marília: & \multicolumn{4}{|c|}{ Vixi, vc numentendeu nada.... tá loko? Tava brincando, Ô... entendeu errado! } \\
\hline$(21: 16)$ Carlos: & \multicolumn{4}{|c|}{ Ah... claro... rs rs rs } \\
\hline (21:17) Marília: & \multicolumn{4}{|c|}{ Ô Lúcia!!! Seu marido tá doido! } \\
\hline (21:19) Carlos: & \multicolumn{4}{|c|}{ Mas vc me chamou de safado! \#fato@ } \\
\hline (21:22) Marília: & \multicolumn{4}{|c|}{ Era brincadeira, modo de flaar, ô burro! } \\
\hline (21:22) Carlos: & \multicolumn{4}{|c|}{ Ok, xaprálá.... o que importa mesmo é que teu bolo ficou joia.... rs rs rs } \\
\hline
\end{tabular}


(21:23) Marília: Ficou.... D_D quando "vocÊs" virem em casa, faço de novo. Pros DOIS....

(21:24) Carlos: Tudo bem.... sem crise....

(21:25) Marília: Bom, soninho batendo... vou dormir...

(21:25) Carlos: Eu também to morrendo de sono...

(21:26) Carlos: Boa noite!

(21:27) Marília: Até... manda beijo pra lucia ai...

(21:27) Carlos: Ok 